NATIONAL LABORATORY

MANAGED BY UT-BATTELLE

FOR THE DEPARTMENT OF ENERGY

CRADA FINAL REPORT

FOR

CRADA NO. NFE-04-00699

\title{
STRUCTURAL ANALYSIS OF SANDWICH FOAM PANELS
}

\section{April 2010}

Prepared by

X. Sharon Huo, Ph.D., P. E.

Associate Professor of Civil Engineering

Tennessee Technological University

P.O. Box 5032

Cookeville, Tennessee 38505

and

Jan Kosny Ph.D.

Oak Ridge National Laboratory

Building 3147

P.O. Box 2008

Oak Ridge, TN 37831-6070

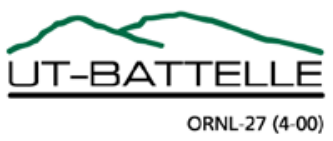




\section{DOCUMENT AVAILABILITY}

Reports produced after January 1, 1996, are generally available free via the U.S. Department of Energy (DOE) Information Bridge.

Web site http://www.osti.gov/bridge

Reports produced before January 1, 1996, may be purchased by members of the public from the following source.

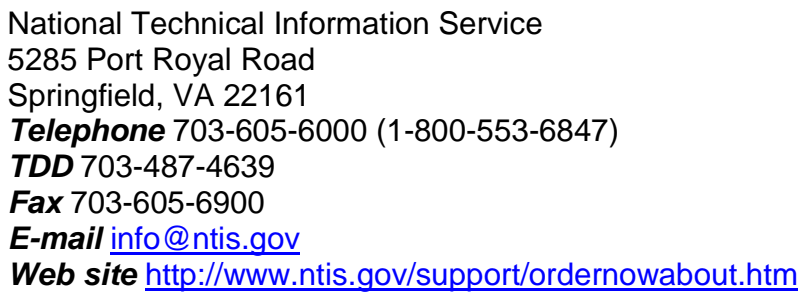

Reports are available to DOE employees, DOE contractors, Energy Technology Data Exchange (ETDE) representatives, and International Nuclear Information System (INIS) representatives from the following source.

Office of Scientific and Technical Information

P.O. Box 62

Oak Ridge, TN 37831

Telephone 865-576-8401

Fax 865-576-5728

E-mail reports@osti.gov

Web site http://www.osti.gov/contact.html

This report was prepared as an account of work sponsored by an agency of the United States Government. Neither the United States Government nor any agency thereof, nor any of their employees, makes any warranty, express or implied, or assumes any legal liability or responsibility for the accuracy, completeness, or usefulness of any information, apparatus, product, or process disclosed, or represents that its use would not infringe privately owned rights. Reference herein to any specific commercial product, process, or service by trade name, trademark, manufacturer, or otherwise, does not necessarily constitute or imply its endorsement, recommendation, or favoring by the United States Government or any agency thereof. The views and opinions of authors expressed herein do not necessarily state or reflect those of the United States Government or any agency thereof. 
Energy and Transportation Science Division

\author{
CRADA FINAL REPORT \\ FOR \\ CRADA NO. NFE-04-00699
}

\title{
STRUCTURAL ANALYSIS OF SANDWICH FOAM PANELS
}

\author{
Submitted to \\ SGI Ventures, Inc. \\ 1800 Bering Drive \\ Suite 501 \\ Houston, TX 77057
}

OAK RIDGE NATIONAL LABORATORY

Oak Ridge, Tennessee 37831-6283

managed by

UT-BATTELLE, LLC

for the

U.S. DEPARTMENT OF ENERGY

under contract DE-AC05-00OR22725

April 2010 



\section{TABEL OF CONTENTS}

Page

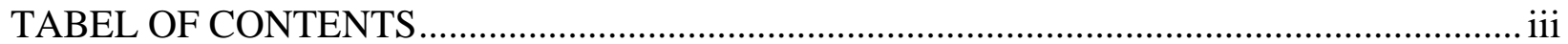

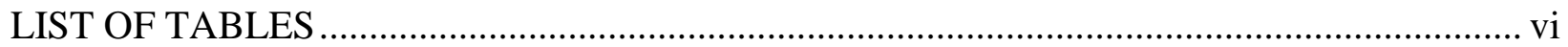

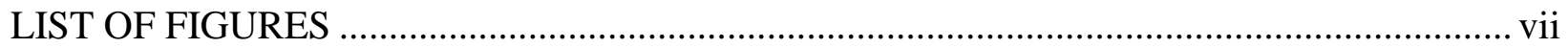

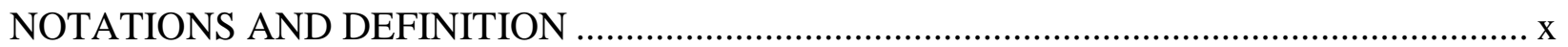

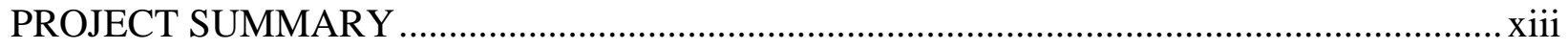

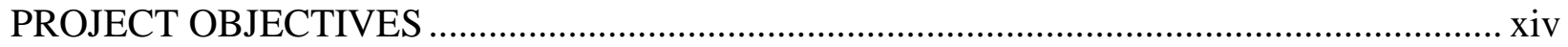

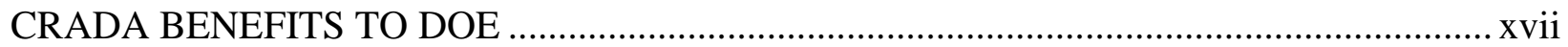

ACKNOWLEDGEMENTS ...........................................................................................

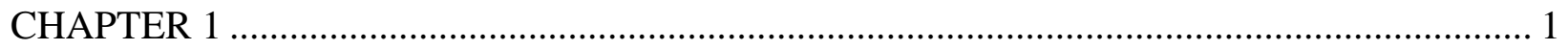

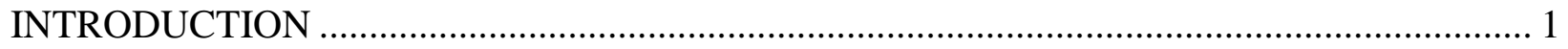

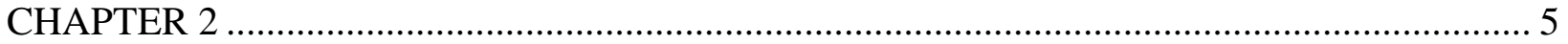

GENERAL INFORMATION OF STRUCTURAL INSULTED PANELS (SIPs) ..................... 5

2.1 Foam Properties ...................................................................................................... 5

2.2 Variation of steel thickness Gages and associated sandwich components ....................... 8

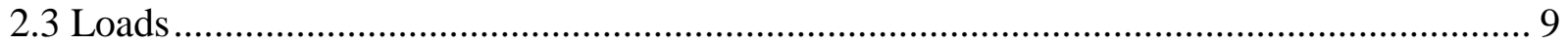

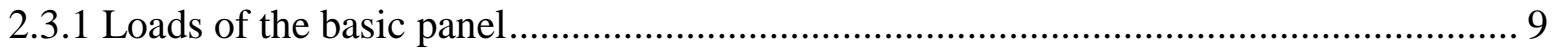

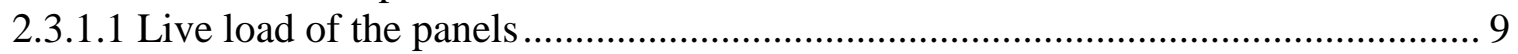

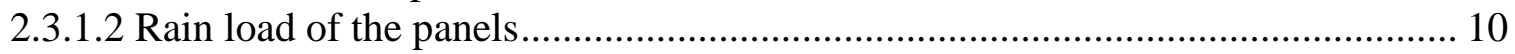

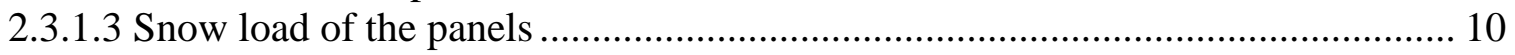

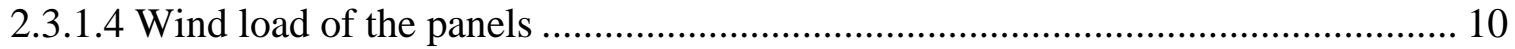

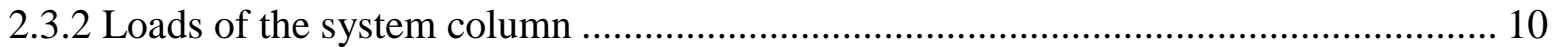

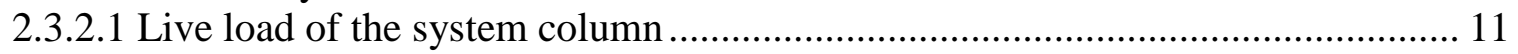

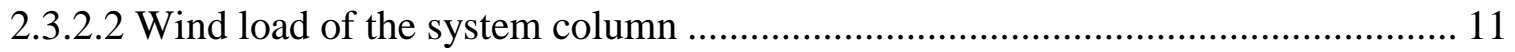

2.3.3 Loads of the window header .............................................................................. 11

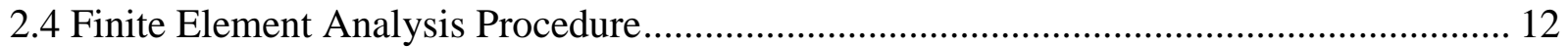

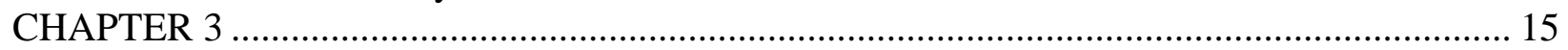

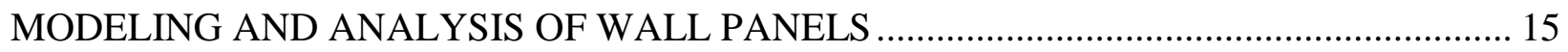

3.1 Description of input and modeling of the basic panel ................................................. 15

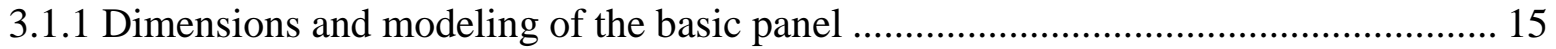

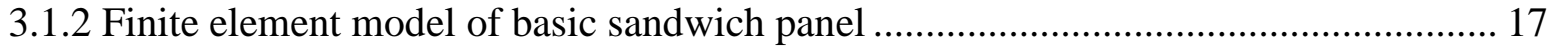

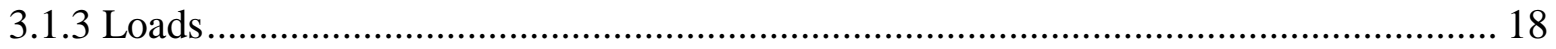

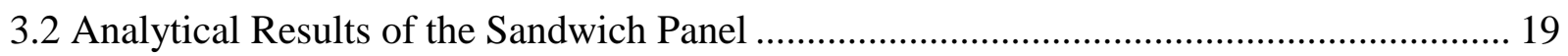

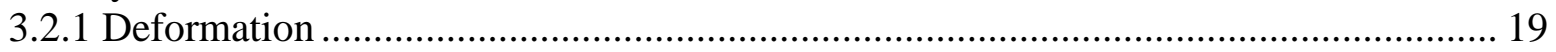

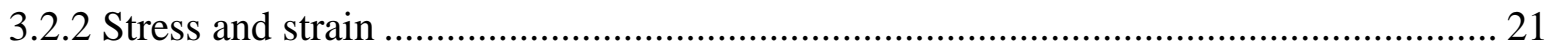

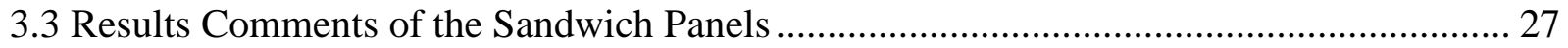

3.4 Load Capability of the Basic Sandwich Panel ............................................................... 29

3.4.1 Vertical load capability of the basic panels ........................................................ 29

3.4.2 Wind load capability of the basic panels .......................................................... 30

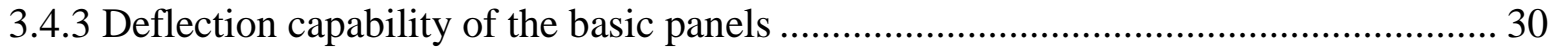

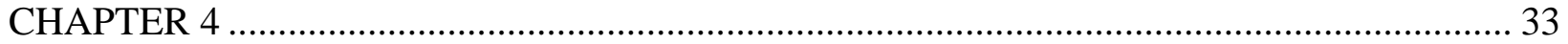

MODELING AND ANALYSIS OF C-SHAPE COLUMNS .............................................. 33 
4.1 Description of Input and Modeling of the C-shape Profiles ........................................... 33

4.1.1 Dimensions and modeling of the C-shape profiles ............................................... 33

4.1.2 Finite element model of column with C-shape Profile ............................................. 34

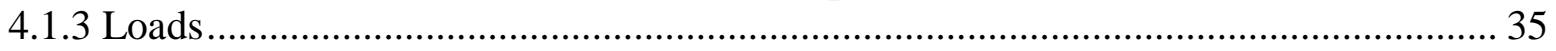

4.2 Analytical Results of the C-shape Profile ................................................................ 37

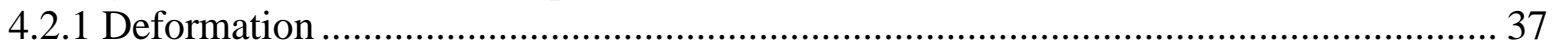

4.2.1.1 Deformation of C-shape profile under the load Case 1 ................................. 37

4.2.1.2 Rotation of C-shape column under the load Case 1.......................................... 40

4.2.1.3 Deformation of C-shape column under the load Case 2 ................................... 44

4.2.1.4 Rotation of C-shape column under the load Case 2 ........................................ 45

4.2.2 Stresses of the C-shape profiles .................................................................. 47

4.2.2.1 Stresses in longitudinal direction of C-shape profile under the load Case 1 ....... 48

4.2.2.2 Stresses in longitudinal direction of C-shape profile under the load Case 2 ........ 52

4.3 Load Capability of the C-shape Profile under the load Case 1........................................ 54

4.3.1 Vertical load capability of the C-shape profile .................................................... 55

4.3.2 Wind load capability of the C-shape profile ................................................... 55

4.3.3 Wind capability of the C-shape profile based on deflection limitation ..................... 56

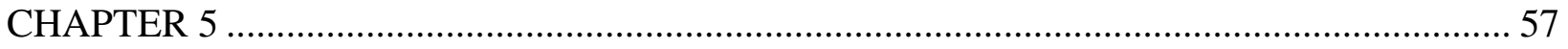

MODELING AND ANALYSIS OF DELTA-SHAPE COLUMNS .................................... 57

5.1 Description of Input and Modeling of Delta-shape Columns ........................................ 57

5.1.1 Dimensions and modeling of the Delta-shape column ........................................... 57

5.1.2 Finite element model of the Delta-shape column ............................................... 58

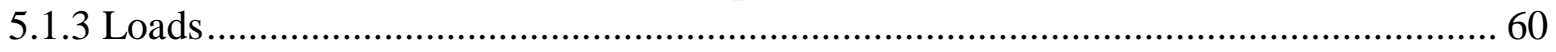

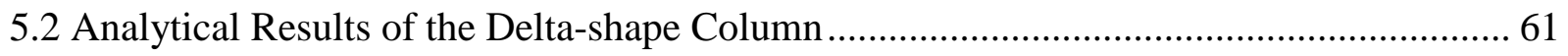

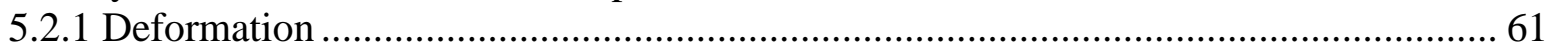

5.2.1.1 Deformation of Delta-shape column under the load Case 1 ............................... 61

5.2.1.2 Deformation of Delta-shape column under the load Case 2 .............................. 63

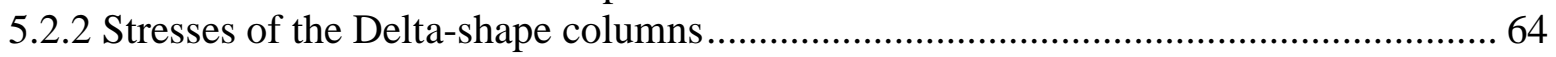

5.2.2.1 Stresses in longitudinal direction of Delta-shape column under load Case 1....... 65

5.2.2.2 Stresses in longitudinal direction of Delta-shape column under load Case 2 ....... 68

5.3 Load Capability of the Delta-shape Column ................................................................ 71

5.3.1 Load Capability of the Delta-shape Column under the load Case 1......................... 71

5.3.1.1 Vertical load capability of the Delta-shape column.......................................... 71

5.3.1.2 Wind load capability of the Delta-shape column............................................ 72

5.3.1.3 Deflection capability of the Delta-shape column.............................................. 72

5.3.2 Vertical Load Capability of the Delta-shape Column under the load Case 2 ............. 72

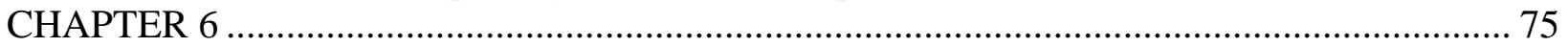

MODELING AND ANALYSIS OF THE ORIGINAL-SHAPE COLUMN ............................ 75

6.1 Description of Input and Modeling of the Original Column without foam...................... 75

6.1.1 Dimensions and modeling of the original column without foam ............................. 75

6.1.2 Finite element model of the original column.................................................. 76

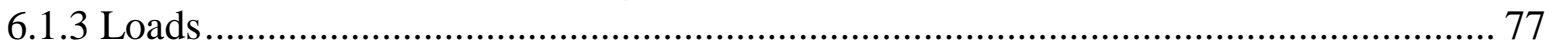

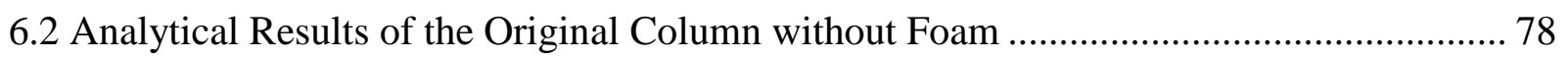

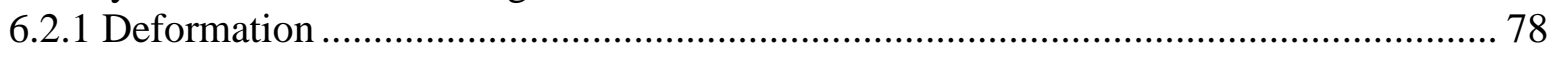

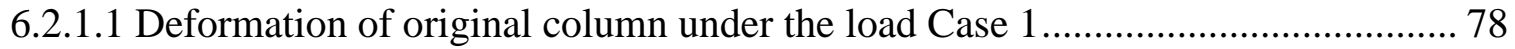

6.2.1.2 Deformation of original column under the load Case 2................................... 80 


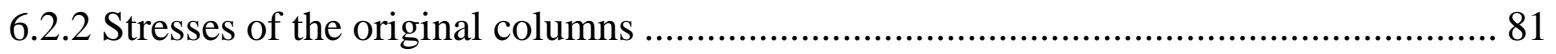

6.2.2.1 Stresses in longitudinal direction of original column under load Case 1 ............. 81

6.2.2.2 Stresses in longitudinal direction of original column under load Case 2 ............. 85

6.3 Description of Input and Modeling of the Original Column with foam .............................. 86

6.3.1 Dimensions and modeling of the original column with foam...................................... 86

6.3.2 Finite element model of the original column with foam.............................................. 87

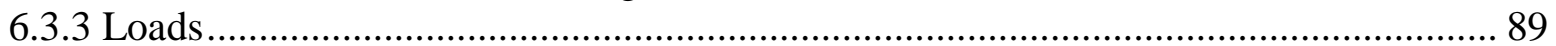

6.4 Analytical Results of the Original Column with Foam ....................................................... 90

6.4.1 Deformation of the original column with foam ........................................................... 90

6.4.2 Stresses of the original column with foam................................................................ 91

6.4.3 Results comments of the original columns with foam................................................ 92

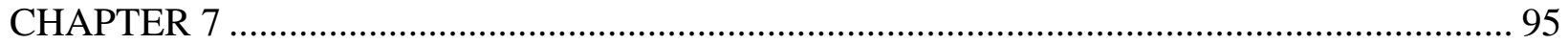

MODELING AND ANALYSIS OF THE WINDOW HEADER ................................................... 95

7.1 Description of Input and Modeling of the window header .............................................. 95

7.1.1 Dimensions and modeling of the window header........................................................ 95

7.1.2 Finite element model of the window header model.................................................... 96

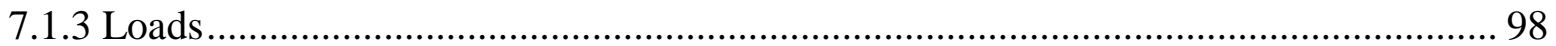

7.2 Analytical results of the window header......................................................................... 99

7.3 Capability of the Window Header …………………................................................... 102

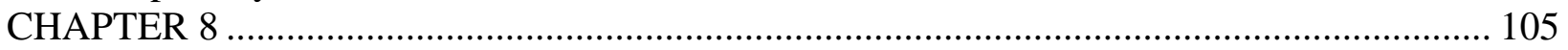

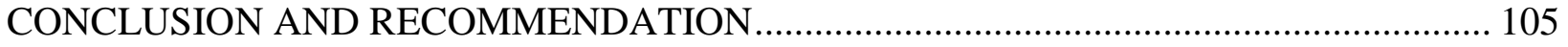

8.1 Conclusion and recommendation about the basic panel................................................... 105

8.2 Conclusions and recommendations about the system column........................................... 106

8.2.1 Comparison of Slenderness Ratio ............................................................................. 106

8.2.2 Comparison of deformations and stresses for columns under load Case 1............... 107

8.2.3 Comparison of deformations and stresses for columns under load Case 2................ 108

8.2.4 Conclusion from analysis of system columns........................................................ 108

8.3 Conclusions on the window header .......................................................................... 109

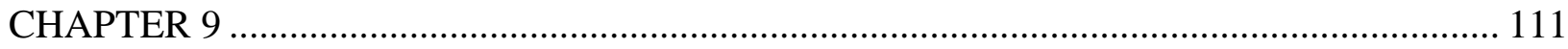

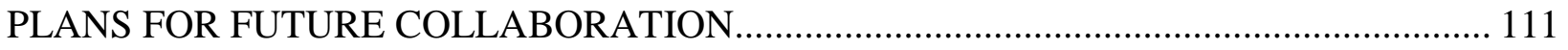




\section{LIST OF TABLES}

Table 2.1 POLYISOCYANURATE RIGID FOAM INSULATION (nominal 2 lb. density)........ 5 Table 2.2 POLYISOCYANURATE RIGID FOAM INSULATION (nominal 2.5 lb. density)..... 6 Table 2.3 POLYISOCYANURATE RIGID FOAM INSULATION (nominal 3 lb. density)......... 6 Table 2.4 POLYISOCYANURATE RIGID FOAM INSULATION (nominal 4 lb. density)........ 7

Table 2.5 Properties of PU foam of SIPs system ......................................................................... 7

Table 2.6 Material property of the steel facings of the SIPs panel .................................................... 8

Table 2.7 SIP system components studied............................................................................. 8

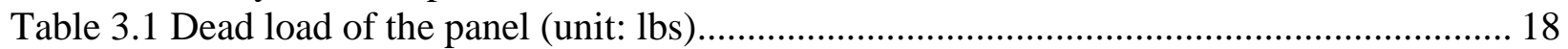

Table 3.2 Summary of the maximum deformation and stresses of the panels .............................. 27

Table 3.3 Vertical load capability (Rain load) of the basic panel.................................................... 30

Table 3.4 Horizontal load capability (Wind load) of the basic panel .............................................. 30

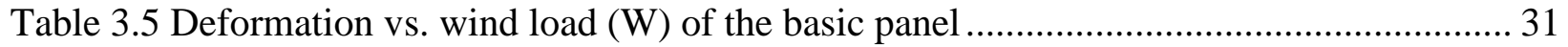

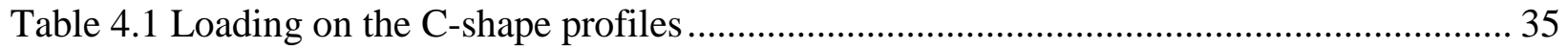

Table 4.2 Vertical load capability (Rain load) of the C-shape profile............................................. 55

Table 4.3 Horizontal load capability (Wind load) of the C-shape profile ....................................... 55

Table 4.4 Deformation vs. wind load (W) of the C-shape profile ................................................ 56

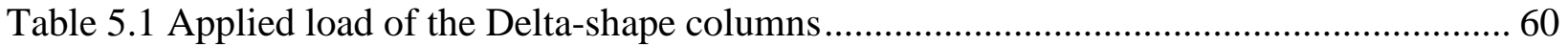

Table 5.2 Vertical load capability (Rain load) of the Delta-shape column ................................... 71

Table 5.3 Horizontal load capability (Wind load) of the Delta-shape column............................... 72

Table 5.4 Deformation vs. wind load (W) of the Delta-shape column.......................................... 72

Table 5.5 Vertical load capability (Rain load) of the Delta-shape column .................................. 73

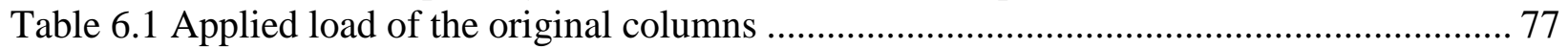

Table 6.2 Summary of the maximum stresses in the original column with foam ......................... 93

Table 7.1 Summary of the maximum stresses in the window header.......................................... 101

Table 8.1 Comparison of Slenderness Ratio for the Studied columns ........................................ 106

Table 8.2 Deformations and Stresses of the Studied Columns under Load Case 1.................... 107

Table 8.3 Deformations and Stresses of the Studied Columns under Load Case 2 ...................... 108 


\section{LIST OF FIGURES}

Figure 2.1 the plan view of the low-rise residential building (unit: feet) ................................. 9

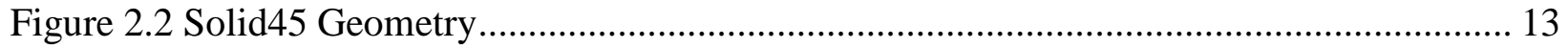

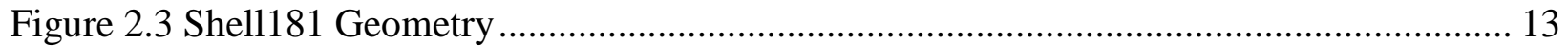

Figure 3.1 Cross-section of the basic panel model (unit: inches) ............................................. 15

Figure 3.2 Elevation of the panel model ........................................................................... 16

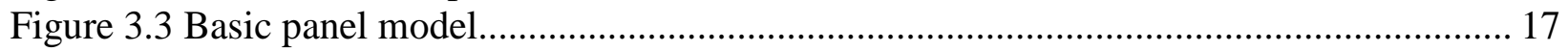

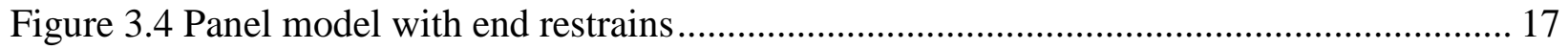

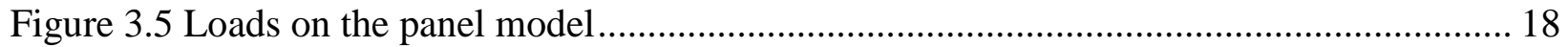

Figure 3.6 Deformation of the panel with 24 Gage (unit: inches) ............................................. 19

Figure 3.7 Deformation of the panel with 25 Gage (unit: inches) ............................................ 20

Figure 3.8 Deformation of the panel with 26 Gage (unit: inches) ............................................ 20

Figure 3.9 Stresses in z direction in the front steel facing with 24 Gage (unit: psi)................... 21

Figure 3.10 Stresses in z direction in the front steel facing with 25 Gage (unit: psi).................. 22

Figure 3.11 Stresses in z direction in the front steel facing with 26 Gage (unit: psi)................. 22

Figure 3.12 Stresses in $\mathrm{z}$ direction in the back steel facing with 24 Gage (unit: psi).................. 23

Figure 3.13 Stresses in z direction in the back steel facing with 25 Gage (unit: psi)................. 23

Figure 3.14 Stresses in z direction in the back steel facing with 26 Gage (unit: psi).................. 24

Figure 3.15 Stresses in z direction in the front side of foam with 24 Gage (unit: psi)............... 24

Figure 3.16 Stresses in z direction in the front side of foam with 25 Gage (unit: psi)................ 25

Figure 3.17 Stresses in $\mathrm{z}$ direction in the front side of foam with 26 Gage (unit: psi)................ 25

Figure 3.18 Stresses in $\mathrm{z}$ direction in the back side of foam with 24 Gage (unit: psi) ................ 26

Figure 3.19 Stresses in $\mathrm{z}$ direction in the back side of foam with 25 Gage (unit: psi) ................. 26

Figure 3.20 Stresses in z direction in the back side of foam with 26 Gage (unit: psi) ................ 27

Figure 3.21 Maximum deformation of panel vs. modulus of elasticity of foam (24 Gage) ........ 28

Figure 3.22 Maximum deformation of panel vs. modulus of elasticity of foam (25 Gage) ........ 28

Figure 3.23 Maximum deformation of panel vs. modulus of elasticity of foam (26 Gage) ......... 29

Figure 4.1 Cross-section of C-shape profile (unit: inches) ..................................................... 33

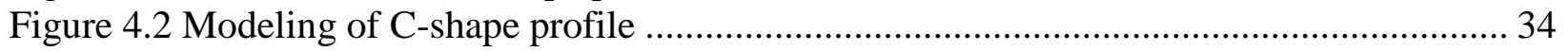

Figure 4.3 The 3-D C-shape profile model ........................................................................... 34

Figure 4.4 Model of the C-shape profile with end restrains ................................................. 35

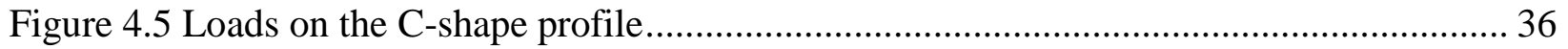

Figure 4.6 Deformation of C2×4 C-shape profile with 16 Gage (unit: inches) .......................... 37

Figure 4.7 Deformation of C2×6 C-shape profile with 16 Gage (unit: inches) .......................... 38

Figure 4.8 Deformation of C2×4 C-shape profile with 20 Gage (unit: inches) ........................... 38

Figure 4.9 Deformation of C2×6 C-shape profile with 20 Gage (unit: inches) .......................... 39

Figure 4.10 Cross-section view of C-shape 16 Gage $(\mathrm{C} 2 \times 4)$............................................... 40

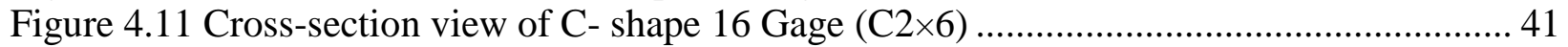

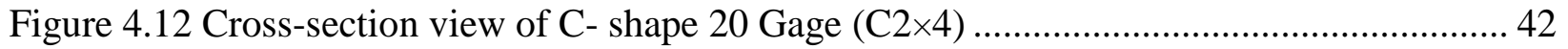

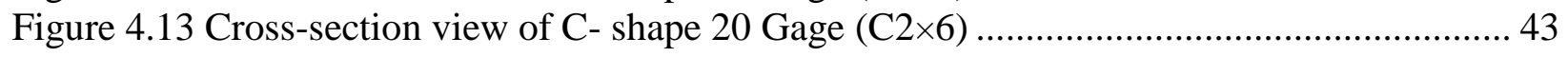

Figure 4.14 Deformation of C2×4 C-shape profile with 16 Gage (unit: inches) ........................ 44

Figure 4.15 Deformation of C 2×6 C-shape profile with 16 Gage (unit: inches) ....................... 44

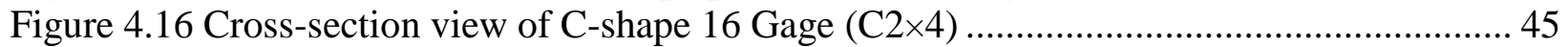

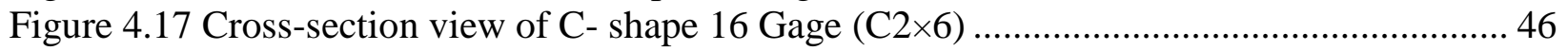


Figure 4.18 Stresses in the back side of C2×4 profile with 16 Gage (units: psi)....................... 48

Figure 4.19 Stresses in the front side of C2×4 profile with 16 Gage (units: psi) ....................... 48

Figure 4.20 Stresses in the back side of C2×6 profile with 16 Gage (units: psi)....................... 49

Figure 4.21 Stresses in the front side of C2×6 profile with 16 Gage (units: psi) ....................... 49

Figure 4.22 Stresses in the back side of C2×4 profile with 20 Gage (units: psi)....................... 50

Figure 4.23 Stresses in the front side of $\mathrm{C} 2 \times 4$ profile with 20 Gage (units: psi) ....................... 50

Figure 4.24 Stresses in the back side of C2×6 profile with 20 Gage (units: psi)....................... 51

Figure 4.25 Stresses in the front side of C2×6 profile with 20 Gage (units: psi) ...................... 51

Figure 4.26 Stresses in the back side of $\mathrm{C} 2 \times 4$ profile with 16 Gage (units: psi)....................... 52

Figure 4.27 Stresses in the front side of C2×4 profile with 16 Gage (units: psi) ....................... 52

Figure 4.28 Stresses in the back side of C2×6 profile with 16 Gage (units: psi)....................... 53

Figure 4.29 Stresses in the front side of C2×6 profile with 16 Gage (units: psi) ....................... 53

Figure 5.1 Cross-section of the Delta-shape column (unit: inches) ........................................ 57

Figure 5.2 Elevation of the Delta-shape column ................................................................ 58

Figure 5.3 3-D Delta-shape column model.................................................................. 59

Figure 5.4 Delta-shape column model with end restraints .............................................. 59

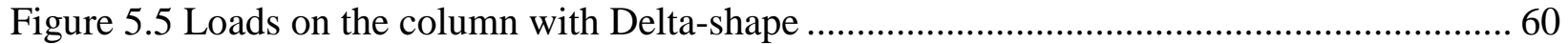

Figure 5.6 Deformation of the Delta-shape column with 16 Gage (unit: inches)....................... 61

Figure 5.7 Deformation of the Delta-shape column with 18 Gage (unit: inches)........................ 62

Figure 5.8 Deformation of the Delta-shape column with 20 Gage (unit: inches)....................... 62

Figure 5.9 Deformation of the Delta-shape column with 16 Gage (unit: inches)....................... 63

Figure 5.10 Deformation of the Delta-shape column with 18 Gage (unit: inches)..................... 63

Figure 5.11 Deformation of the Delta-shape column with 20 Gage (unit: inches)..................... 64

Figure 5.12 Stresses in the back side of the delta-shape column with 16 Gage (unit: psi)........... 65

Figure 5.13 Stresses in the front side of the delta-shape column with 16 Gage (unit: psi) .......... 65

Figure 5.14 Stresses in the back side of the delta-shape column with 18 Gage (unit: psi).......... 66

Figure 5.15 Stresses in the front side of the delta-shape column with 18 Gage (unit: psi) .......... 66

Figure 5.16 Stresses in the back side of the delta-shape column with 20 Gage (unit: psi).......... 67

Figure 5.17 Stresses in the front side of the delta-shape column with 20 Gage (unit: psi) ......... 67

Figure 5.18 Stresses in the back side of the delta-shape column with 16 Gage (unit: psi).......... 68

Figure 5.19 Stresses in the front side of the delta-shape column with 16 Gage (unit: psi) .......... 68

Figure 5.20 Stresses in the back side of the delta-shape column with 18 Gage (unit: psi).......... 69

Figure 5.21 Stresses in the front side of the delta-shape column with 18 Gage (unit: psi) .......... 69

Figure 5.22 Stresses in the back side of the delta-shape column with 20 Gage (unit: psi).......... 70

Figure 5.23 Stresses in the front side of the delta-shape column with 20 Gage (unit: psi) ......... 70

Figure 6.1 Cross-section of the original-shape column (unit: inches) .................................... 75

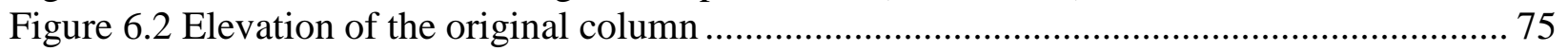

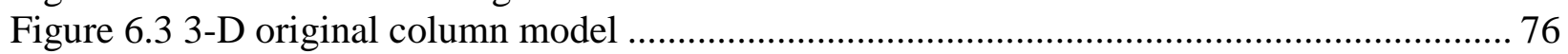

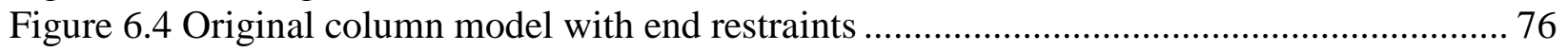

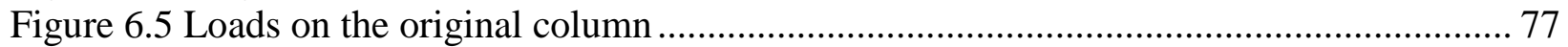

Figure 6.6 Deformation of the original column with 16 Gage (unit: inches) ........................... 78

Figure 6.7 Deformation of the original column with 18 Gage (unit: inches) ............................ 79

Figure 6.8 Deformation of the original column with 20 Gage (unit: inches) ............................ 79

Figure 6.9 Deformation of the original column with 16 Gage (unit: inches) ............................ 80

Figure 6.10 Stresses in the back side of the Original column with 16 Gage (unit: inches)......... 81

Figure 6.11 Stresses in the front side of the Original column with 16 Gage (unit: inches).......... 82 
Figure 6.12 Stresses in the back side of the Original column with 18 Gage (unit: inches).......... 82

Figure 6.13 Stresses in the front side of the Original column with 18 Gage (unit: inches)......... 83

Figure 6.14 Stresses in the back side of the Original column with 20 Gage (unit: inches)......... 83

Figure 6.15 Stresses in the front side of the Original column with 20 Gage (unit: inches)......... 84

Figure 6.16 Stresses in the back side of the Original column with 16 Gage (unit: inches)......... 85

Figure 6.17 Stresses in the front side of the Original column with 16 Gage (unit: inches)......... 85

Figure 6.18 Cross-section of the original column with foam (unit: inches) .............................. 86

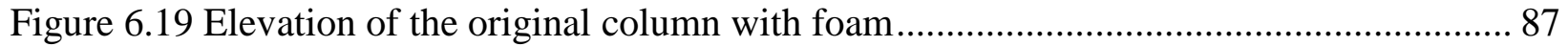

Figure 6.20 Original column model with foam ............................................................ 88

Figure 6.21 End restrains of the original column with foam ............................................. 88

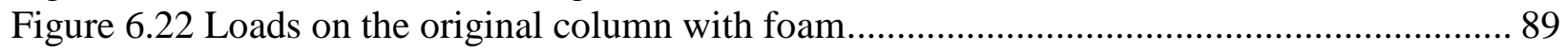

Figure 6.23 Deformation of the original column with foam (unit: inches) .............................. 90

Figure 6.24 Stresses in the longitudinal direction at the steel facings (unit: psi) ....................... 91

Figure 6.25 Stresses in the longitudinal direction in foam (unit: psi)..................................... 92

Figure 6.26 Maximum deformation of original column vs. modulus of elasticity of foam ......... 93

Figure 7.1 Cross-section of the window header model (unit: inches) .................................... 95

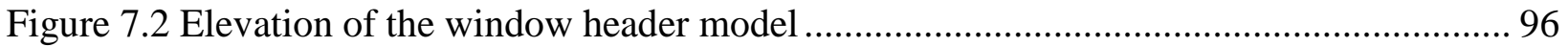

Figure 7.3 Window header finite element model............................................................. 97

Figure 7.4 Window header model with end restrains ...................................................... 97

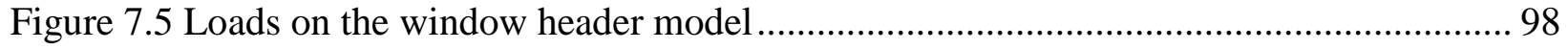

Figure 7.6 Deformation of the window header model (unit: inches)...................................... 99

Figure 7.7 Stresses in $\mathrm{x}$ direction in the back steel facing $\mathrm{y}=0$ (unit: psi) ............................... 99

Figure 7.8 Stresses in longitudinal direction in the front steel facing (unit: psi)..................... 100

Figure 7.9 Stresses in $x$ direction in the front steel facing (unit: psi) .................................... 100

Figure 7.10 Stresses in longitudinal direction in foam (unit: psi)......................................... 101

Figure 7.11 Deformation of the window header model (unit: inches).................................. 102

Figure 7.12 Stresses in longitudinal direction in the back steel facing $y=0$ (unit: psi).............. 103

Figure 7.13 Stresses in longitudinal direction in the front steel facing (unit: psi).................... 103

Figure 7.14 Stresses in longitudinal direction in foam (unit: psi)........................................ 104 


\section{NOTATIONS AND DEFINITION}

The following notations and definitions are utilized throughout the report:
(a) Notations:
$E$ : $\quad$ Modulus of elasticity
$v$ : Poisson's ratio
$\rho$ : Density
$t$ : Thickness
$F_{y}:$ Yield strength

\section{(b) Definitions:}

Slenderness Ratio: The ratio of the effective length of a column to the radius of gyration of the column, both with respect to the same axis of bending. In algebra form, the slenderness ratio is: $\mathrm{KL} / \mathrm{r}$. The slenderness ratio was an important term for columns behavior. A column with larger slenderness ratio is unstable. According to the AISC LRFD Specifications, Article B7, the slenderness ratio of a compression member, KL/r, should not exceed 200.

$$
\left(r=\sqrt{\frac{I}{A}}, \mathrm{~A} \text { is the area of cross section of the column; } \mathrm{I}=\right.\text { the least moment of inertia of the }
$$

column section; $\mathrm{K}=$ the effective coefficient; $\mathrm{L}=$ the actual length of the column. $K L=$ effective length (length of an equivalent hinged-hinged column)).

Maximum Deflection: The maximum value of member deformation along its length. Limitation for the maximum deflection is normally specified in the Design code. The deflection limitation of basic panel deformation was L/240 $=0.45$ inch, and the limitation of column deformation was $\mathrm{L} / 360=0.3$ inch.

Maximum Rotation: The maximum value of rotated angle about member axis along its length. 
Maximum tensile (compressive) stress: The maximum positive (negative) value of the node stress. The limitation of the maximum stress of the steel facing is:

$\phi F_{\text {steel }}=0.85 \times 33 k s i=28.05 k s i$ (Yield strength $\left.F_{y}=33 k s i\right)$. 



\section{PROJECT SUMMARY}

The Sandwich Panel Technologies including Structural Insulated Panels (SIPs) can be used to replace the conventional wooden-frame construction method. The main purpose of this Cooperative Research and Development Agreement (CRADA) between UT-Battelle, LLC and SGI Venture, Inc. was to design a novel high R-value type of metal sandwich panelized technology. This CRADA project report presents design concept discussion and numerical analysis results from thermal performance study of this new building envelope system. The main objective of this work was to develop a basic concept of a new generation of wall panel technologies which will have R-value over R-20 will use thermal mass to improve energy performance in cooling dominated climates and will be $100 \%$ termite resistant.

The main advantages of using sandwich panels are as follows: (1) better energy saving structural panels with high and uniform overall wall R-value across the elevation that could not be achieved in traditional walls; and (2) reducing the use of raw materials or need for virgin lumber. For better utilization of these Sandwich panels, engineers need to have a thorough understanding of the actual performance of the panels and system. Detailed analysis and study on the capacities and deformation of individual panels and its assembly have to be performed to achieve that goal. The major project activity was to conduct structural analysis of the stresses, strains, load capacities, and deformations of individual sandwich components under various load cases. The analysis simulated the actual loading conditions of the regular residential building and used actual material properties of the steel facings and foam. 


\section{PROJECT OBJECTIVES}

The main purpose of this Cooperative Research and Development Agreement (CRADA) between UT-Battelle, LLC and SGI Venture Inc. was to design a novel high R-value type of metal sandwich panelized technology This CRADA project report presents design concept discussion and numerical analysis results from thermal performance study of this new building envelope system. The main objective of this work was to develop a basic concept of a new generation of wall panel technologies which will have R-value over R-20 will use thermal mass to improve energy performance in cooling dominated climates and will be $100 \%$ termite resistant.

In recent years, increased levels of insulation, high-performance windows, improved construction practices that reduce air leakage and sensible and latent heat-recovery ventilators have significantly reduced heating and cooling loads. Continued improvements in these building envelope technologies suggests that in the near future residences could be routinely constructed with very low heating and cooling loads. Thus, it is clear that developing very low-energy houses will require improved integration between the traditional building envelope and new features like active thermal mass, radiant barriers, cool surfaces, etc.

The proposed building envelope technology maximizes this integration by utilizing a highly-efficient building envelope with high-R thermal insulation, active thermal mass and superior air-tightness. The project team approach was to combine four common building technologies in a novel way. Structural Insulated Panel (SIP) technology was utilized as a structural vehicle and for high-R thermal insulation. Novel approach to panel-to-panel connections provided excellent air and moisture tightness, but it also works in a similar way as conventional wall framing. 
Thermal mass effect will be provided by proprietary thermally-active inserts. It is anticipated that, these new wall panels will utilize internal radiant barriers. Application of steel panel facing will provide impermeable surfaces minimizing degradation of the system R-value (foam aging process caused by the emission to the atmosphere of the foam blowing agent). An application of only steel components (no wood) will provide 100\% termite resistance of the proposed wall technology. In addition, the panels are lightweight and will be $100 \%$ recyclable. Structures made of the panels can be dismantled, moved and reconfigured into a different structure. We believe that the research proposed here points the way to a new generation of affordable, comfortable, very-low energy buildings that are easily integrated with renewable and fuel cell energy-conversion technologies.

The major objective of the project was to conduct structural analysis of the stresses, strains, load capacities, and deformations of individual sandwich components under various load cases. The analysis simulated the actual loading conditions of the regular residential building and used actual material properties of the steel facings and foam. The research team used ANSYS 8.0 software to perform the proposed analysis. The obtained results include the stress and strain levels, deformation, and load capacities of the structural components of sandwich system, such as panels, columns, and header, under various loading conditions. The analytical results would enhance the understanding of the structural performance of sandwich panels.

The research revealed the following results: (a) For the panel with metal facing Gage 24, 25 and 26, the maximum deformation occurred at about middle height of the panels, the maximum tensile stress in longitudinal direction occurred at the bottom of the front steel facing and the maximum compressive stress occurs at about 45" from the top surface of the front steel facing. The magnitude of the column deformation depended on the modulus of elasticity of foam. 
(b) The slenderness ratios of C-channel columns and Delta columns were less than the limitation of 200 and the columns were acceptable. The slenderness ratios of original columns, however, were larger than the specified limitation, and the columns were not acceptable for lateral stability. Torsional deformation (twist) could be clearly observed in the C-shape columns under loading due to the asymmetry about the weak axis in the cross-section. The delta-shape and original columns exhibited flexural buckling deformation only. The analysis of stresses and deformations showed Delta columns made of 16 gage and 18 gage steel were the only columns that met structural requirements for load scenario when columns were subjected to wind load based on 36 in wide tributary area;

In the window header, the maximum tensile and compressive stresses in steel occurred at the bottom of the front facing, close to the support while the maximum compressive stress in the PU foam were almost equal to zero, indicating the steel facings carried almost all of the loads on the window header. 


\section{CRADA BENEFITS TO DOE}

The main purpose of this Cooperative Research and Development Agreement (CRADA) between UT-Battelle, LLC and SGI Venture Inc. was to design a basic concept of a new generation of metal sandwich panelized technologies. The primary goal of this CRADA was conceptual development of a new type of building envelope technology which will have an Rvalue over R-20 and will use thermal mass to improve energy performance in cooling dominated climates and will be $100 \%$ termite resistant. The second project goal was experimental and numerical analysis of the structural performance of metal sandwich panels with relatively complex, multilayer configuration of two or more different materials or subsystems, including intermediate panel connectors, novel structural members, core foam materials, and the occasional use of phase change materials.

Performed numerical analysis demonstrated excellent structural performance of new sandwich panels. It was found that twist or torsional deformation could be clearly observed in the C-shape columns under loading due to the asymmetry about the weak axis in the cross-section. The newly developed delta-shape and original columns exhibited flexural buckling deformation only. The maximum deformations of delta-shape and original columns occurred at about 45"- 46" from the top surfaces of the columns. The stresses, deformations and slenderness ratios in Cchannel columns and Delta columns were acceptable when columns were subjected to wind load based on the column area only. The slenderness ratio of original columns was unacceptable. Only Delta columns made of 16 and 18 gage steel met all of the design criteria when the columns subjected to wind load based on 36 in wide tributary area (24 in. for C-shape column). For columns with the same Gage and under the same loads, the Delta column had the smallest stress and the original column had the largest stress. Considering the deformation, slenderness ratio 
and stresses of the columns, Delta-columns made of 16 and 18 gage steel were the best choice among the columns studied in this project.

We believe that the research results described here points the way to a new generation of affordable, comfortable, very-low energy buildings. 


\section{ACKNOWLEDGEMENTS}

The authors wish to gratefully acknowledge the financial support of the SGI Ventures, Inc. and the technical support of the Oak Ridge National Laboratory (ORNL) Energy Efficiency and Renewable Energy (EERE) Program for this research. Particularly, the authors would like to thank Ms. Sally Gaskin at SGI Ventures, Inc. and Dr. Marilyn Brown at ORNL EERE for their assistance. The authors also gratefully acknowledge the financial support and management of the Center for Energy Systems Research and Department of Civil and Environmental Engineering at Tennessee Technological University. The support provided by Dr. Sastry Munukutla, Etter Staggs, Sandy Garrision, Linda Lee, and Tony Greenway is greatly appreciated. 



\section{CHAPTER 1}

\section{INTRODUCTION}

Most residential buildings in the USA are made of wood-frames, constructed with lumbers and nailed together to form the skeleton of the buildings. Although these buildings are economical to build, they have faced concerns on effective utilization of natural resources (wood) and their durability performance. As construction grows, experts are expecting a shortage in construction material supply, especially the raw materials. The shortage of the construction materials would lead to the price increase for the materials and as a result, the increasing price gouges the homeowners and construction industry. It is very common that, the wood-framed buildings are susceptible to moisture and air leakage to and from outside the building, which generates higher energy consumption, and very often moisture-related durability problem. In case of using steel-studs, the overall R-value of the building is reduced considerably by thermal

bridging. Furthermore, the thermal shorts along the wall can often lead to local de-colorization of the wall surfaces or sometimes water condensation that can attract mildew. Therefore, a development of structural insulated building panels that could overcome the shortcomings of the wood-frames structures is in high demand now. The sandwich panels developed by Dr. Jan Kosny at the Oak Ridge National Laboratory (ORNL) are the ones to meet these needs for residential buildings. This technology consists of insulation foam core and structural metal facings. The foam core can be made of expanded polystyrene (EPS), polyurethane or polyisocyanurate foam and is sandwiched between two metal skins.

When these panels are engineered and assembled properly, they will act as load bearing structural members and need no frame of skeleton. For better utilization of these panels, engineers need to have a thorough understanding of the actual performance of the panels and 
other system components. Detailed analysis of the load capacities and potential deformation of individual panels and their assembly had to be performed to achieve this goal.

The main objective of this project is to conduct structural analysis of the stresses, strains, load capacities, and deformations of individual technology components under various load cases. The analysis simulated the actual loading conditions of the regular residential building and used actual material properties of the steel facing of steel structural columns and foam. The research team used ANSYS 8.0 software to perform the proposed analysis. The analytical results would enhance the understanding of the structural performance of the sandwich wall system.

The following research approaches were undertaken to achieve the objectives of this study. The material properties of the panel components including skins and foam were carefully selected first because the accuracy of the material properties is crucial to correctness of the analysis. The basic dimensions of the panels and columns were obtained from the information provided by Dr. Kosny from the ORNL.

The modeling and analysis began with the main sandwich panel component. The panel was precisely modeled following the finalized dimensions and collected material properties. Three gages of the steel facing, gages 24,25 , and 26 , were considered in the analysis. The loads on the panel simulated the actual load conditions in low-rise residential buildings that included the gravity load and wind load. The analytical results included the stresses and strains, the axial and flexural load capacities, and deformations of the panels.

The system columns were modeled in a similar manner as the panel. The system column was the most important structural elements in the structural insulated panel (SIP) system. A total of three types of system columns were analyzed, they are originally proposed columns, Cchannel columns, and Delta columns. For each column type, two or more metal gages of the 
steel facings were considered. A comparison of the structural performance of the analyzed columns was also conducted. In addition, the slenderness ratio of each column type was examined.

The window/door header was the flexural member in the sandwich system. The top and bottom C-shape tracks in the header were the major element in carrying the bending moment. These elements were modeled precisely in accordance to the header details. Distributed loads were applied along the length of the header. The load capacity on the header was determined based on the maximum allowable stresses in the header components.

This report summarizes the findings of the research activities conducted on the request of SustainBuild, LLC. The results include the stress and strain levels as well as the deformation of the panels, columns, and header under various loading conditions. The load capacities of these structural components are also presented in the report. 



\section{CHAPTER 2}

\section{GENERAL INFORMATION OF STRUCTURAL INSULTED PANELS (SIPs)}

\subsection{Foam Properties}

The foam properties used in this study were mostly based on the information found Dyplast Products Polyisocyanurate insulation (ISO-C1) Specifications. DP-ISO-C1 is rigid closed-cell polyisocyanurate thermal insulation foam that can be fabricated into any required shape. The ISO-C1 has been tested according to 18 ASTM Specifications for various material properties. Based on ASTM E84 standards, ISO-C1 has a Class 1 flame spread/smoke development rating, and the highest R-value per inch of any commercially available insulation. The Dyplast Product ISO-C1 was available in 2, 2.5, 3, and $4 \mathrm{lb} / \mathrm{ft}^{3}$ densities. Tables 2.1 through 2.4 show the physical properties of the ISO-C1 Polyisocyanurate rigid foam insulation used in analysis.

Table 2.1 Polyisocyanurate rigid foam insulation (nominal 2 lb. density)

\begin{tabular}{|c|c|c|c|}
\hline Physical Properties & ASTM Method & \multicolumn{2}{|c|}{ English Units } \\
\hline Density & D 1622 & 2.1 & $\mathrm{lb} / \mathrm{ft}^{3}$ \\
\hline Compressive Strength & D 1621 & & \\
\hline Parallel to Rise (Thickness) & & 26 & $\mathrm{lb} / \mathrm{in}^{2}$ \\
\hline Perpendicular to Rise (Width) & & 29 & $\mathrm{lb} / \mathrm{in}^{2}$ \\
\hline Shear Strength: Parallel and Perpendicular & C 273 & 27 & $\mathrm{lb} / \mathrm{in}^{2}$ \\
\hline Shear Modulus & C 273 & 346 & lb/in ${ }^{2}$ \\
\hline Tensile Strength: Parallel and Perpendicular & D 1623 & 33 & $\mathrm{lb} / \mathrm{in}^{2}$ \\
\hline Flexural Strength: Parallel and Perpendicular & C 203 & 54 & $\mathrm{lb} / \mathrm{in}^{2}$ \\
\hline Flexural Modulus & C 203 & 864 & $\mathrm{lb} / \mathrm{in}^{2}$ \\
\hline Closed Cell Content & D 2856 & $>95$ & $\%$ \\
\hline Buoyancy & & TBD & $\mathrm{lb} / \mathrm{ft}^{3}$ \\
\hline Water Absorption & C 272 & 0.24 & \% by volume \\
\hline Water Vapor Permeance & E 96 & 2.33 & perm-inch \\
\hline Service Temperature $^{3}$ & & $\begin{array}{l}-297 \text { to } \\
+300\end{array}$ & ${ }^{\circ} \mathrm{F}$ \\
\hline
\end{tabular}


Table 2.2 Polyisocyanurate rigid foam insulation (nominal $2.5 \mathrm{lb}$. density)

\begin{tabular}{llll}
\hline Physical Properties & ASTM Method & \multicolumn{2}{l}{ English Units } \\
\hline Density & D 1622 & 2.5 & $\mathrm{lb} / \mathrm{ft}^{3}$ \\
\hline Compressive Strength & D 1621 & & \\
\hline Parallel to Rise (Thickness) & & 37 & $\mathrm{lb} / \mathrm{in}^{2}$ \\
\hline Perpendicular to Rise (Width) & & 31 & $\mathrm{lb} / \mathrm{in}^{2}$ \\
\hline Shear Strength: Parallel and Perpendicular & C 273 & 26 & $\mathrm{lb} / \mathrm{in}^{2}$ \\
\hline Shear Modulus & C 273 & 253 & $\mathrm{lb} / \mathrm{in}^{2}$ \\
\hline Tensile Strength: Parallel and Perpendicular & D 1623 & 43 & ${\mathrm{lb} / \mathrm{in}^{2}}^{2}$ \\
\hline Flexural Strength: Parallel and Perpendicular & C 203 & 56 & ${\mathrm{lb} / \mathrm{in}^{2}}^{2}$ \\
\hline Flexural Modulus & C 203 & 961 & $\mathrm{lb} / \mathrm{in}^{2}$ \\
\hline Closed Cell Content & D 2856 & $>98$ & $\%$ \\
\hline Buoyancy & & TBD & $\mathrm{lb} / \mathrm{ft}^{3}$ \\
\hline Water Absorption & C 272 & $<0.1$ & $\%$ by volume \\
\hline Water Vapor Permeance & E 96 & 2.23 & $\mathrm{perm}-$ inch \\
\hline Service Temperature $^{3}$ & & -297 to & ${ }^{\circ} \mathrm{F}$ \\
& & +300 & \\
\hline
\end{tabular}

Table 2.3 Polyisocyanurate rigid foam insulation (nominal $3 \mathrm{lb}$. density)

\begin{tabular}{llll}
\hline Physical Properties & ASTM Method & \multicolumn{2}{l}{ English Units } \\
\hline Density & D 1622 & 3 & $\mathrm{lb} / \mathrm{ft}^{3}$ \\
\hline Compressive Strength & D 1621 & & \\
\hline Parallel to Rise (Thickness) & & 45 & $\mathrm{lb} / \mathrm{in}^{2}$ \\
\hline Perpendicular to Rise (Width) & & 38 & $\mathrm{lb} / \mathrm{in}^{2}$ \\
\hline Shear Strength: Parallel and Perpendicular & C 273 & 30 & $\mathrm{lb} / \mathrm{in}^{2}$ \\
\hline Shear Modulus & C 273 & 289 & $\mathrm{lb} / \mathrm{in}^{2}$ \\
\hline Tensile Strength: Parallel and Perpendicular & D 1623 & 47 & ${\mathrm{lb} / \mathrm{in}^{2}}^{2}$ \\
\hline Flexural Strength: Parallel and Perpendicular & C 203 & 70 & $\mathrm{lb} / \mathrm{in}^{2}$ \\
\hline Flexural Modulus & C 203 & 1290 & $\mathrm{lb} / \mathrm{in}^{2}$ \\
\hline Closed Cell Content & D 2856 & $>98$ & $\%$ \\
\hline Buoyancy & & TBD & $\mathrm{lb} / \mathrm{ft}^{3}$ \\
\hline Water Absorption & C 272 & $<0.1$ & $\%$ by volume \\
\hline Water Vapor Permeance & E 96 & 1.98 & $\mathrm{perm}-\mathrm{inch}$ \\
\hline Service Temperature & & -297 to & ${ }^{\circ} \mathrm{F}$ \\
\hline & & +300 & \\
\hline
\end{tabular}


Table 2.4 Polyisocyanurate rigid foam insulation (nominal $4 \mathrm{lb}$. density)

\begin{tabular}{|c|c|c|c|}
\hline Physical Properties & ASTM Method & English Units & \\
\hline Density $^{3}$ & D 1622 & 4 & $\mathrm{lb} / \mathrm{ft}^{3}$ \\
\hline Compressive Strength $^{3}$ & D 1621 & & \\
\hline Parallel to Rise (Thickness) & & 82 & $\mathrm{lb} / \mathrm{in}^{2}$ \\
\hline Perpendicular to Rise (Width) & & 73 & $\mathrm{lb} / \mathrm{in}^{2}$ \\
\hline Shear Strength: Parallel and Perpendicular & C 273 & 34.4 & $\mathrm{lb} / \mathrm{in}^{2}$ \\
\hline Shear Modulus & C 273 & 315 & $\mathrm{lb} / \mathrm{in}^{2}$ \\
\hline Tensile Strength: Parallel and Perpendicular & D 1623 & 61 & $\mathrm{lb} / \mathrm{in}^{2}$ \\
\hline Flexural Strength: Parallel and Perpendicular & C 203 & 123 & $\mathrm{lb} / \mathrm{in}^{2}$ \\
\hline Flexural Modulus & C 203 & 2331 & $\mathrm{lb} / \mathrm{in}^{2}$ \\
\hline Closed Cell Content & D 2856 & $>98$ & $\%$ \\
\hline Buoyancy & & TBD & $\mathrm{lb} / \mathrm{ft}^{3}$ \\
\hline Water Absorption & C 272 & $<0.1$ & $\%$ by volume \\
\hline Water Vapor Permeance & E 96 & 0.7 & perm-inch \\
\hline Service Temperature $^{3}$ & & -297 to +300 & ${ }^{\circ} \mathrm{F}$ \\
\hline
\end{tabular}

The research team also collected the information on properties from the BASF Corporation. Their product Elastospray 82302 was a two component, polyurethane spray foam system with a unit weight ranging from 2.0 to $3.0 \mathrm{lb} / \mathrm{ft}^{3}$. Although, according to the data sheet, the available structural property was the compressive strength only, the information was helpful in determining the material properties used for analysis of the ORNL sandwich panels. Table 2.5 shows the approximate properties of PU foam with a density of $3 \mathrm{lb} / \mathrm{ft}^{3}$ used in this research.

Table 2.5 Properties of PU foam of SIPs system

\begin{tabular}{lcc}
\hline Physical Properties & \multicolumn{2}{c}{ English Units } \\
\hline Density $^{3}$ & 3 & $\mathrm{lb} / \mathrm{ft}^{3}$ \\
\hline Shear Modulus & 1000 & $\mathrm{lb} / \mathrm{in}^{2}$ \\
\hline Poisson's ratio & 0.4 & $/$ \\
\hline Compressive strength & 50 & $\mathrm{psi}$ \\
\hline Tensile strength & 70 & $\mathrm{psi}$ \\
\hline Shear strength & 50 & $\mathrm{psi}$ \\
\hline Flexural strength & 70 & $\mathrm{psi}$ \\
\hline
\end{tabular}




\subsection{Variation of steel thickness Gages and associated sandwich components}

In this research, the panels, columns, and system header made of different steel thicknesses were investigated. The use of varied metal gages allowed the research team to conduct a parametric study for the performance of wall sandwiches and other system components. Table 2.6 shows the properties of steel facings. Table 2.7 lists the basic panel, system columns and window header studied in this research.

Table 2.6 Material property of the steel facings of the SIPs panel

\begin{tabular}{cccccc}
\hline Steel thickness & $\mathrm{t}($ in. $)$ & $\boldsymbol{F}_{y}(\mathbf{k s i})$ & $E(\mathrm{ksi})$ & $v$ & $\rho(p c i)$ \\
\hline 16 Gage & 0.0598 & 33 & 29000 & 0.3 & 0.284 \\
\hline 18 Gage & 0.0478 & 33 & 29000 & 0.3 & 0.284 \\
\hline 20 Gage & 0.0359 & 33 & 29000 & 0.3 & 0.284 \\
\hline 24 Gage & 0.0239 & 33 & 29000 & 0.3 & 0.284 \\
\hline 25 Gage & 0.0209 & 33 & 29000 & 0.3 & 0.284 \\
\hline 26 Gage & 0.0179 & 33 & 29000 & 0.3 & 0.284 \\
\hline
\end{tabular}

Table 2.7 SIP system components studied

\begin{tabular}{cccccccc}
\hline \multirow{2}{*}{$\begin{array}{c}\text { Steel } \\
\text { thickness }\end{array}$} & Basic & \multicolumn{2}{c}{ C-shape column } & \multicolumn{2}{c}{ Delta-shape column } & $\begin{array}{c}\text { Original } \\
\text { column }\end{array}$ & $\begin{array}{c}\text { Window } \\
\text { header }\end{array}$ \\
\cline { 3 - 6 } 16 Gage & $\mathrm{N}$ & $\mathrm{Y}$ & $\mathrm{Y}$ & $\mathrm{Y}$ & $\mathrm{Y}$ & $\mathrm{Y}$ & $\mathrm{Y}$ \\
\hline 18 Gage & $\mathrm{N}$ & $\mathrm{N}$ & $\mathrm{N}$ & $\mathrm{Y}$ & $\mathrm{Y}$ & $\mathrm{Y}$ & $\mathrm{N}$ \\
\hline 20 Gage & $\mathrm{N}$ & $\mathrm{Y}$ & $\mathrm{Y}$ & $\mathrm{Y}$ & $\mathrm{Y}$ & $\mathrm{Y}$ & $\mathrm{N}$ \\
\hline 24 Gage & $\mathrm{Y}$ & $\mathrm{N}$ & $\mathrm{N}$ & $\mathrm{N}$ & $\mathrm{N}$ & $\mathrm{N}$ & $\mathrm{N}$ \\
\hline 25 Gage & $\mathrm{Y}$ & $\mathrm{N}$ & $\mathrm{N}$ & $\mathrm{N}$ & $\mathrm{N}$ & $\mathrm{N}$ & $\mathrm{N}$ \\
\hline 26 Gage & $\mathrm{Y}$ & $\mathrm{N}$ & $\mathrm{N}$ & $\mathrm{N}$ & $\mathrm{N}$ & $\mathrm{N}$ & $\mathrm{N}$ \\
\hline
\end{tabular}

Note: $\mathrm{Y}$ denotes the gage will be studied; $\mathrm{N}$ denotes the gage won't be studied. 


\subsection{Loads}

Loads applied on the analyzed sandwich wall system include the dead loads, live loads and wind load. Dead loads of the panel include the self-weight of the studied component. Live loads and wind load were introduced based on the analysis of residential building. The plane dimensions of low-rise residential buildings were assumed as shown in Figure 2.1. The height of the basic wall panel and system column was $9 \mathrm{ft}$ (108 inches).

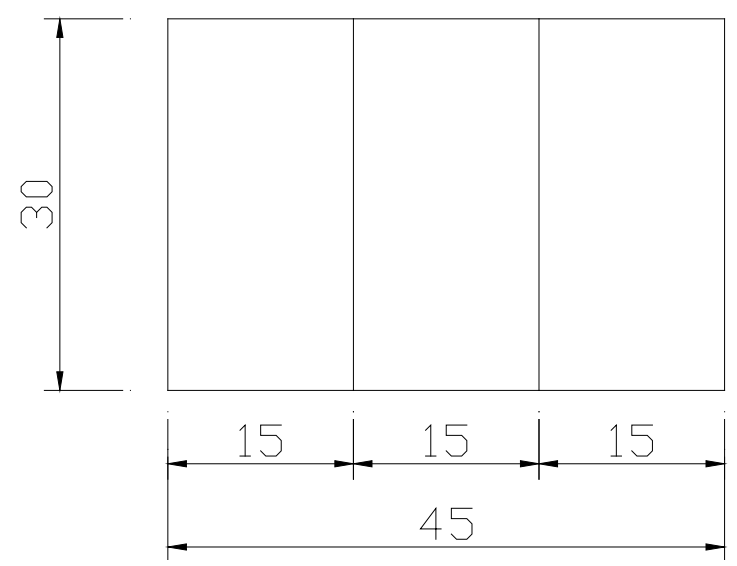

Figure 2.1 The plan view of the low-rise residential building (unit: feet)

\subsubsection{Loads of the basic panel}

\subsubsection{Live load of the panels}

The live load of the basic panel was calculated according the ASCE - 7 Standard Specifications - Minimum Design Loads for Buildings and Other Structures (ASCE 7-98).

Live load (floor): L_fl = 50psf; Live load (Roof): L_rf = 20psf;

From Figure 2.1, the circumference of the building $C=150 \mathrm{ft}$ and the area $A=1,350 \mathrm{ft}^{2}$. The average width of the basic panel Width $=3.04$ in. Therefore, live load due to occupancy: $\mathrm{L}=$ L_fl $\times \mathrm{A} / \mathrm{C} /$ Width $=12.34 \mathrm{psi}$; and roof live load: $\mathrm{Lr}=\mathrm{L} \_\mathrm{rf} \times \mathrm{A} / \mathrm{C} / \mathrm{Width}=24.93 \mathrm{psi}$. The summation of the live load on the basic panel $\mathrm{L}_{\mathrm{L}}=\mathrm{L}+\mathrm{Lr}=17.27$ psi. 


\subsubsection{Rain load of the panels}

The design rainfall for the building is 3 inches per hour, and the runoff quantity for each scupper is $\mathrm{Q}=0.0104 \mathrm{Ai}=42.12$, assuming the scuppers are 4 inches above the roof surface. Referring to the specification, the hydraulic head at this flow rate for the scupper used $d h=1.754$. The design roof rain load, then, was Rain $=5.2(\mathrm{ds}+\mathrm{dh})=30 \mathrm{psf}$. The rain load on the basic panel was:

$$
\mathrm{R}=\mathrm{Rain} \times \mathrm{A} / \mathrm{C} / \text { Width }=7.40 \mathrm{psi}
$$

\subsubsection{Snow load of the panels}

According to the specification, Snow load was assumed: Snow $=20$ psf. Snow load on the basic panel $S=$ Snow $\times$ A/C/Width $=4.93 p s i$

\subsubsection{Wind load of the panels}

In wind load calculation, the basic wind load was taken as V = $100 \mathrm{mph}$; Important factor: $\mathrm{I}=1.0$; Directionality factor $\mathrm{K}_{\mathrm{d}}=0.85$; Velocity pressure exposure coefficient $\mathrm{K}_{\mathrm{z}}=0.912 ; \mathrm{GC}_{\mathrm{pf}}=$ 0.8 (The external pressure coefficient, which was found using Figures 6-5 to 6-7 in ASCE 7-98); $\mathrm{GC}_{\mathrm{pi}}=0.18$ (The internal pressure coefficient and was found on Table 6-7 in ASCE 7-98); The velocity pressure, pounds per square foot, was computed from the equation

$$
\mathrm{q}_{\mathrm{h}}=0.00256 \mathrm{~K}_{\mathrm{d}} \mathrm{K}_{\mathrm{z}} \mathrm{V}^{2} \mathrm{I}=19.85 \mathrm{psf}
$$

The design pressure, in units of pounds per square foot, for wind loads acting on the components and cladding of a low-rise building was specified in Section 6.5.12.4.1 of ASCE 798. That pressure can then be calculated from

$$
\mathrm{P}=\mathrm{q}_{\mathrm{h}}\left[\left(\mathrm{GC}_{\mathrm{pf}}\right) \pm\left(\mathrm{GC}_{\mathrm{pi}}\right)\right]=19.6 \mathrm{psf}=0.136 \mathrm{psi}
$$

\subsubsection{Loads of the system column}

The two following cases of column loading conditions were considered in the study;

Case 1- column carried wind load based on column area only; 
Case 2- column carried wind load based on 36 in wide tributary area (column spacing) for Deltashape and original system columns and 24 in wide tributary area for C-shape column. The deformations and stresses of the system columns were determined under the Case1 load and Case 2 load, respectively.

\subsubsection{Live load of the system column}

The values of the vertical loads which were applied on the column were determined according to the dimensions of column and directly connected panel. For example, the circumference of the Delta-shape column was $C_{\text {delta }}=24.002$ inches; the area of the basic panel $A_{p}=110.4934$ inch $^{2}$; the live load applied on the panel was $L_{L}=L+L r=17.27$ psi. Then the live load applied the Delta-shape was: $\mathrm{P}_{\mathrm{L}}=\mathrm{L}_{\mathrm{L}} * \mathrm{~A}_{\mathrm{p}} / \mathrm{C}_{\text {delta }}=79.503$ (lb/in). The live loads of the other system columns were calculated according to the similar procedure.

\subsubsection{Wind load of the system column}

The width of the front side of Delta-shape column was 3.5 in. When the Delta-shape column was to carry wind load based on 36 in wide tributary area (column spacing), the wind load of the Delta-shape column in load Case 2 became: $W=0.136$ psi *36in./3.5in. =1.3989 psi. The wind load of the other system column was calculated according to the similar procedure.

\subsubsection{Loads of the window header}

The header carries the vertical load that was transferred from the weight of the panel. The height of the basic panel above the window header was assumed as 3 feet, which was one-third of the height of the basic panel. The self-weight of the basic panel was 35.476 lbs for foam and 96.61 lbs for steel facings. The cross-sectional area of the window header $\mathrm{A}_{\mathrm{h}}=37.833 \mathrm{in}^{2}$. Then, the gravity load of the window header $P_{h}=(35.476+96.61) / A_{h} / 3=1.164 p s i$. 


\subsection{Finite Element Analysis Procedure}

ANSYS finite element analysis software is used in the modeling of the ORNL sandwich wall system. Shell elements (Shell181) are used to model the metal facings and solid elements (Solid45) are used to model the foam between the facings.

SOLID45 is used for the 3-D modeling of solid structures. The element is defined by eight nodes having three degrees of freedom at each node: translations in the nodal $\mathrm{x}, \mathrm{y}$, and $\mathrm{z}$ directions. The element has plasticity, creep, swelling, stress stiffening, large deflection, and large strain capabilities. A reduced integration option with hourglass control is available. Figure 2.2 shows the geometry of Solid45.

SHELL181 is suitable for analyzing thin to moderately-thick shell structures. It is a 4-node element with six degrees of freedom at each node: translations in the $\mathrm{x}, \mathrm{y}$, and $\mathrm{z}$ directions, and rotations about the $\mathrm{x}, \mathrm{y}$, and z-axes. SHELL181 is well-suited for linear, large rotation, and/or large strain nonlinear applications. Change in shell thickness is accounted for in nonlinear

analyses. In the element domain, both full and reduced integration schemes are supported. SHELL181 accounts for follower (load stiffness) effects of distributed pressures. Figure 2.3 shows the geometry of Shell181. 

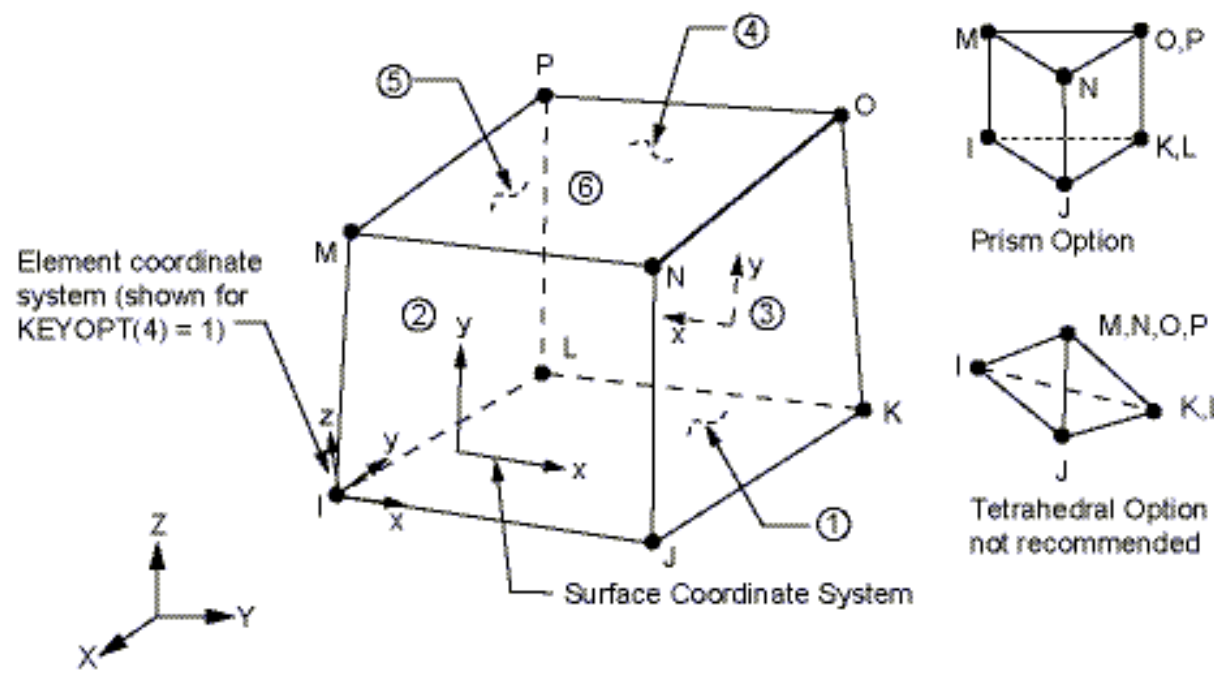

Prism Option

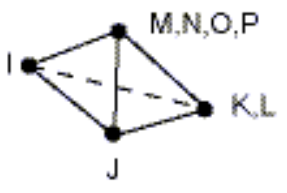

Tetrahedral Option not recommended

Figure 2.2 Solid45 Geometry

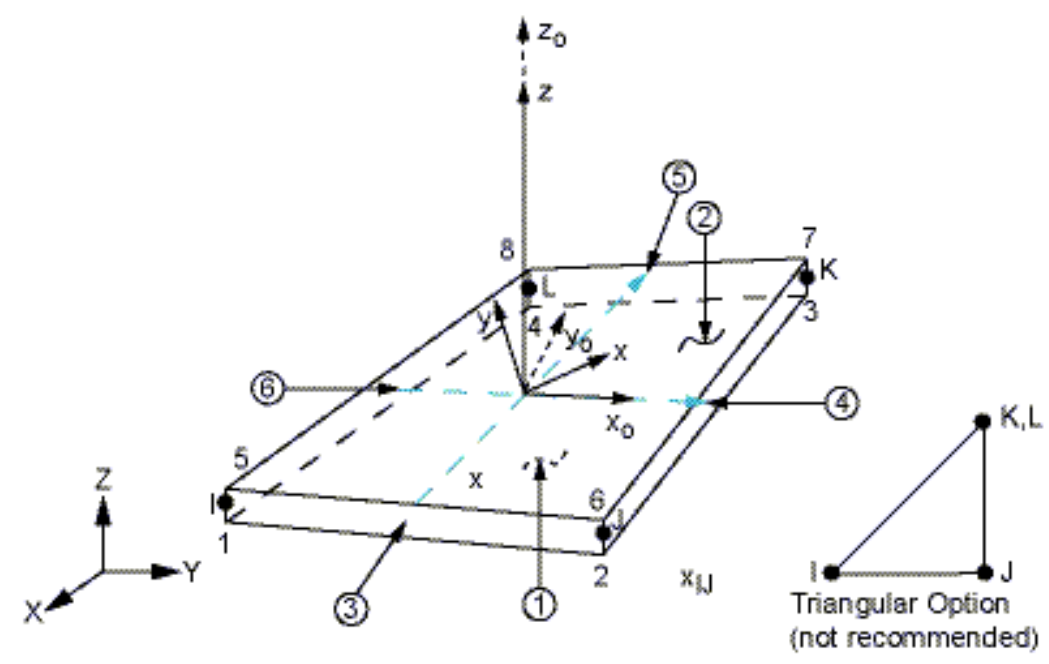

Figure 2.3 Shell181 Geometry 



\section{CHAPTER 3}

\section{MODELING AND ANALYSIS OF WALL PANELS}

The basic panel was the first structural system component to be modeled and analyzed. Three following thicknesses of the wall panel facings were studied, 24, 25, 26 -gage.

\subsection{Description of input and modeling of the basic panel}

\subsubsection{Dimensions and modeling of the basic panel}

Figure 3.1 shows the basic dimension of the cross-section of the panel and Figure 3.2 shows the longitudinal dimension of the panel.

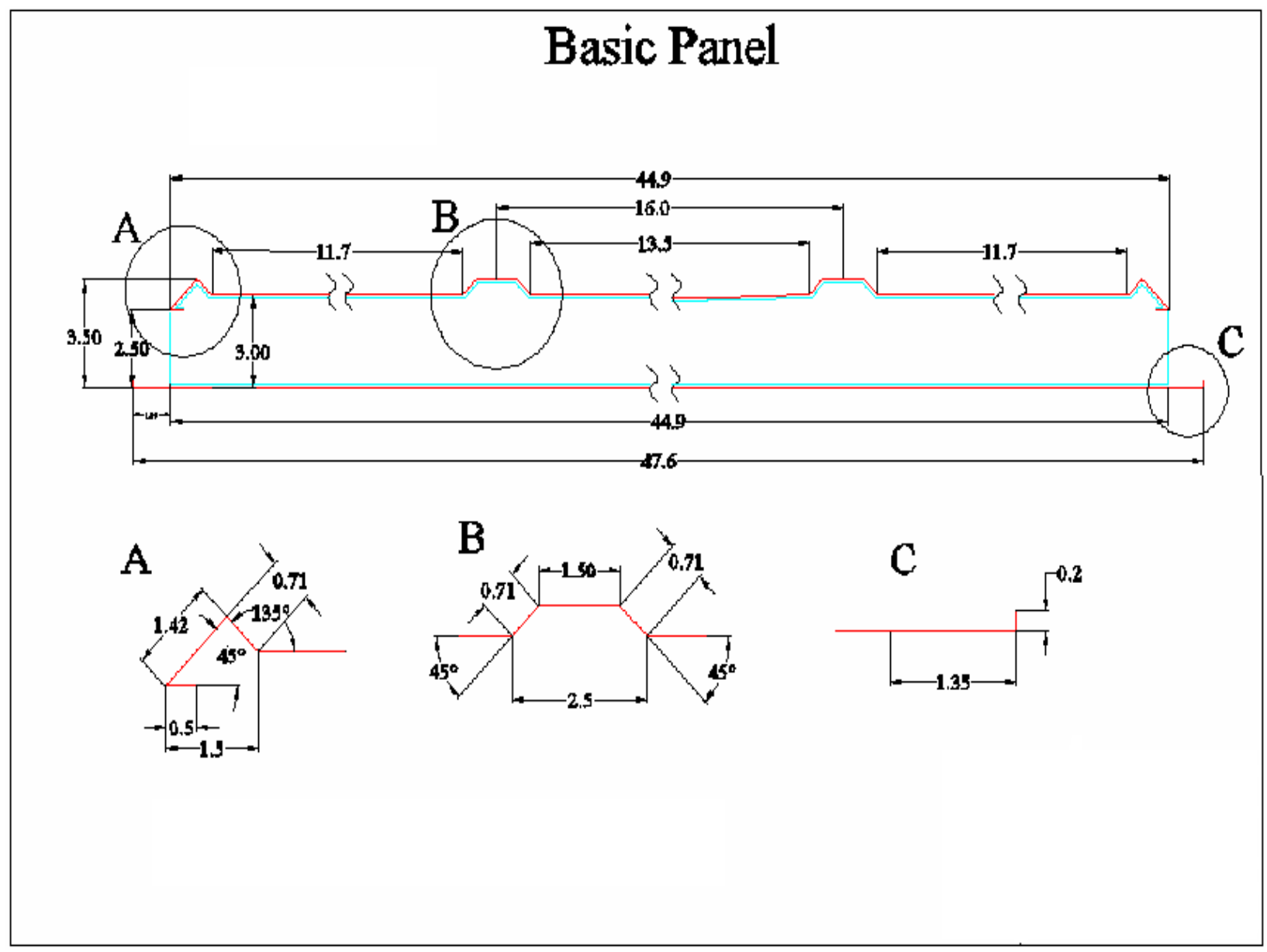

Figure 3.1 Cross-section of the basic panel model (unit: inches) 


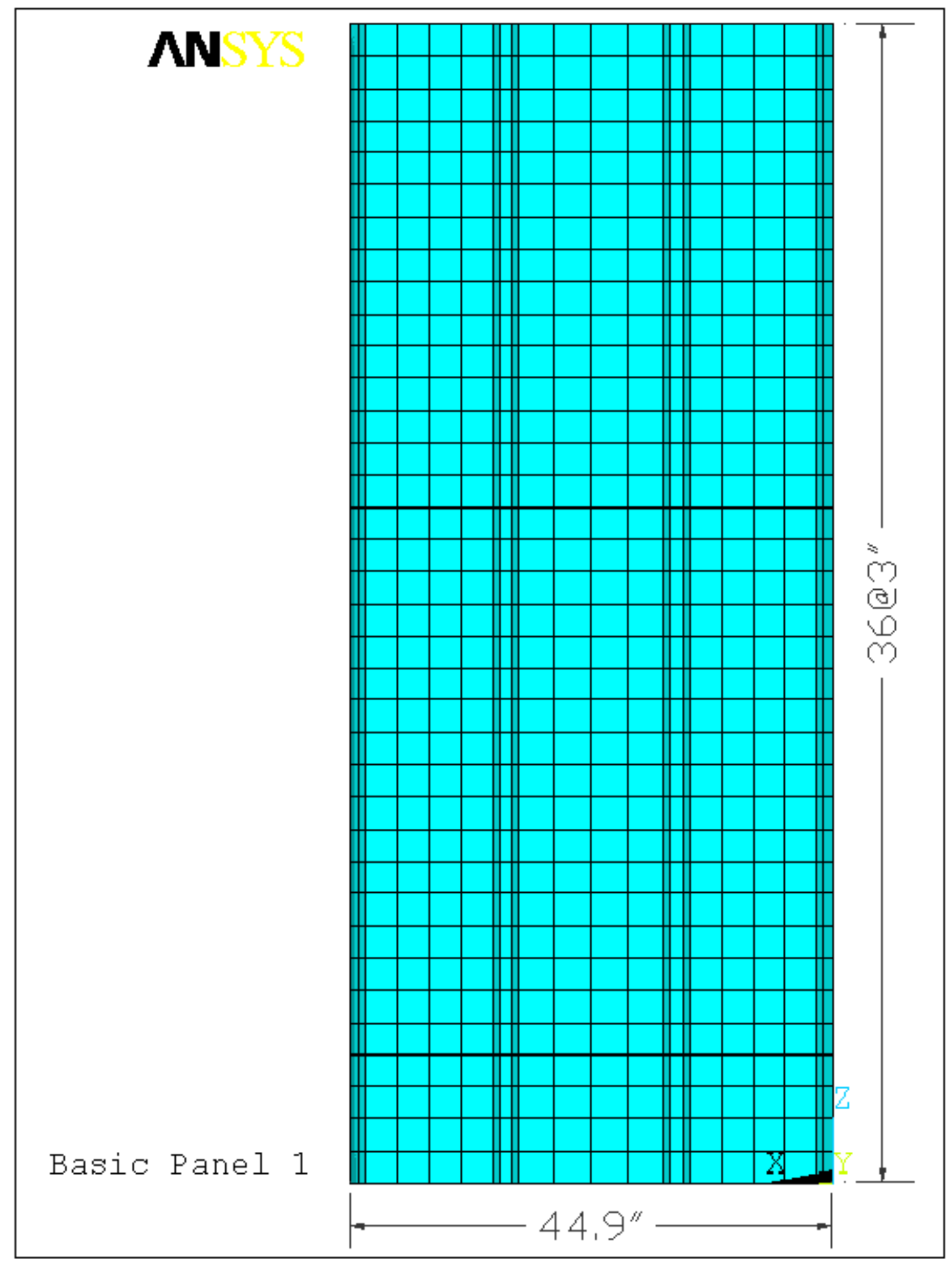

Figure 3.2 Elevation of the panel model 


\subsubsection{Finite element model of basic sandwich panel}

Shell elements (Shell181) were used to model the metal facings and solid elements (Solid45) were used to model the foam core between the facings. As shown in Figure. 3.4, the model was restrained with pin supports at the top of the panel and fix supports at the bottom except the rotation about $\mathrm{x}$ direction.

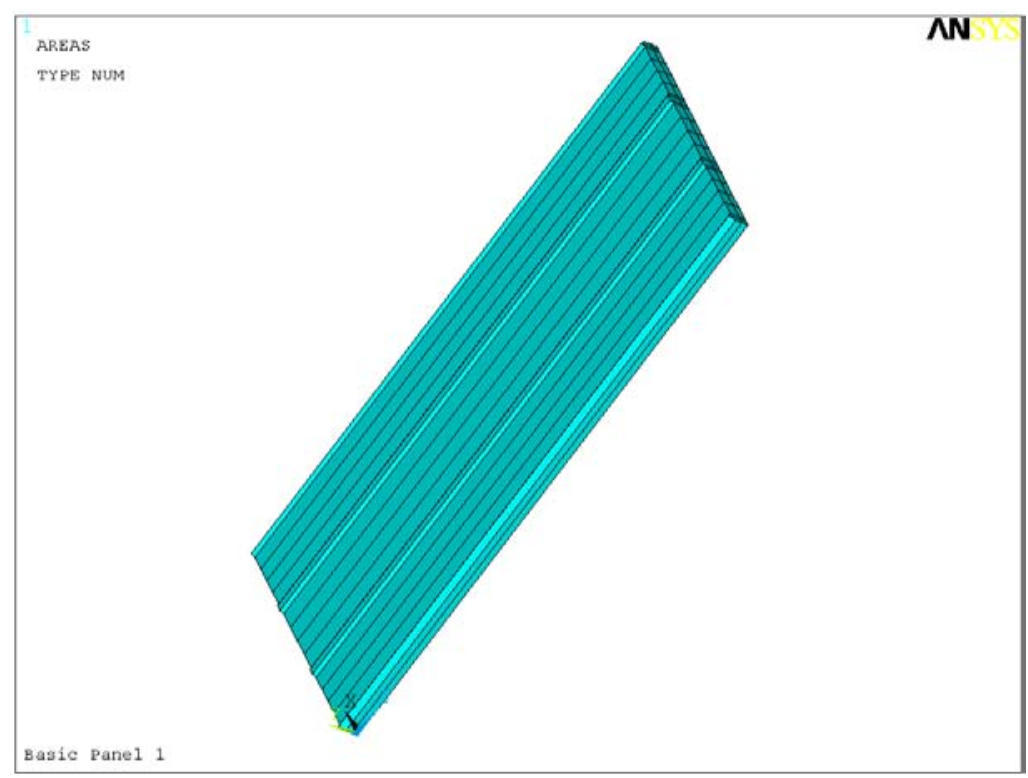

Figure 3.3 Basic panel model

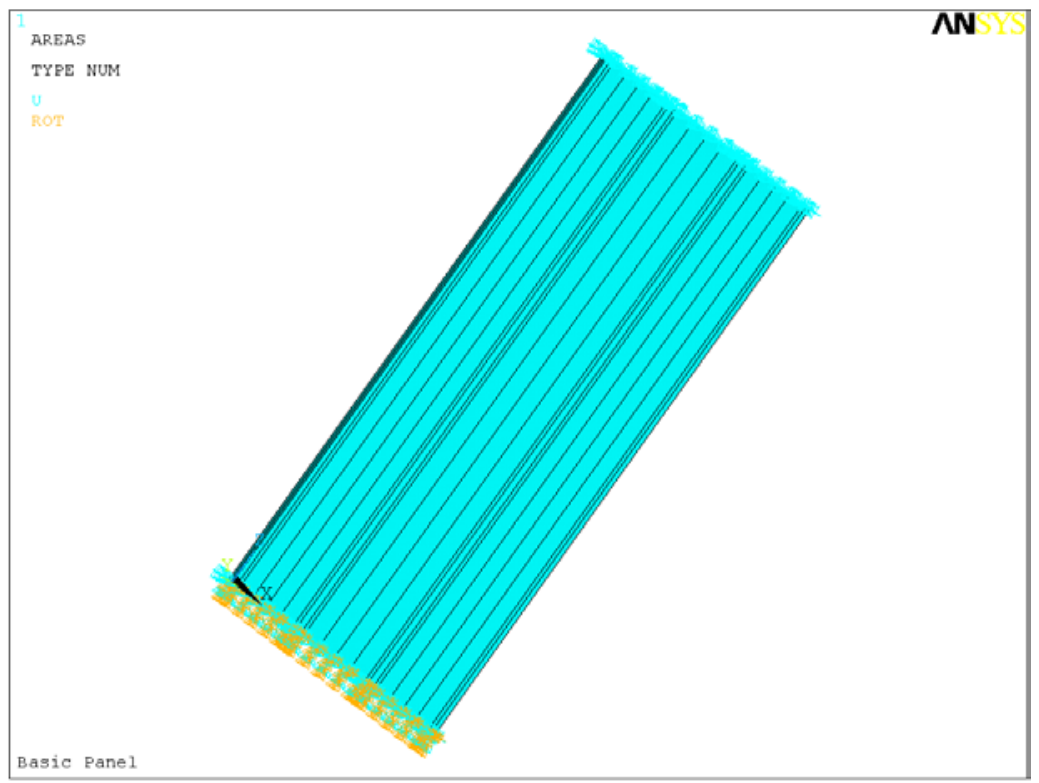

Figure 3.4 Panel model with end restrains 


\subsubsection{Loads}

Live load: $2487 p s f=17.27$ psi, applied on the top of the panel.

Wind load: $19.60 \mathrm{psf}=0.136 \mathrm{psi}$, applied on the steel facing of the panel.

Dead load: Self-weight of the panel are listed in Table 3.1.

Table 3.1 Dead load of the panel (unit: lbs)

\begin{tabular}{lccc}
\hline & 24 Gage & 25 Gage & 26 Gage \\
\hline Foam & 35.476 & 35.476 & 35.476 \\
\hline Steel Sheets & 96.61 & 84.48 & 72.36 \\
\hline
\end{tabular}

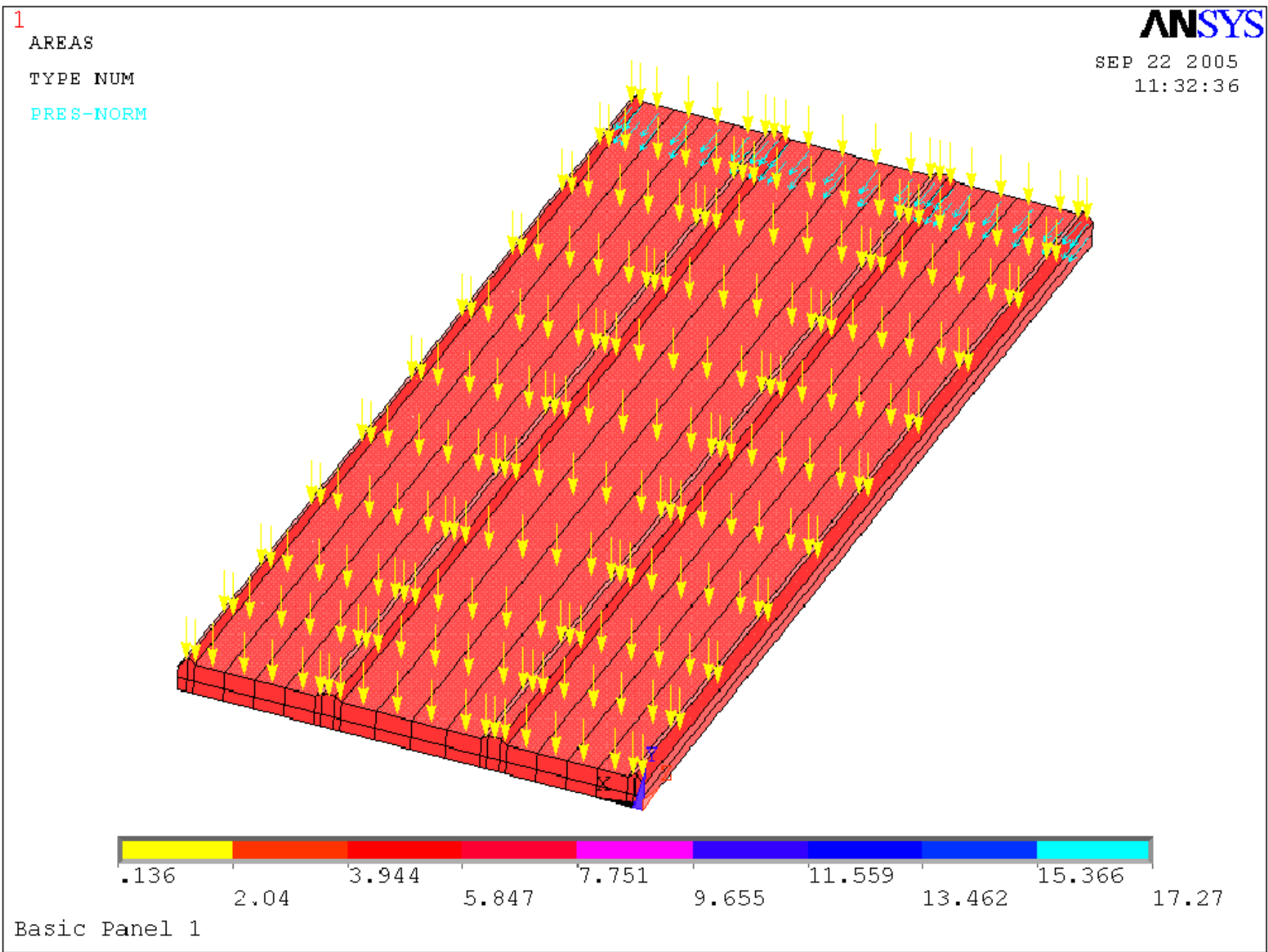

Figure 3.5 Loads on the panel model 


\subsection{Analytical Results of the Sandwich Panel}

\subsubsection{Deformation}

Figures 3.6, 3.7 and 3.8 show the lateral deformation of panels with 24, 25 and 26 gage, respectively. As the thickness of the steel facing increased, the deformation of the panel decreased.

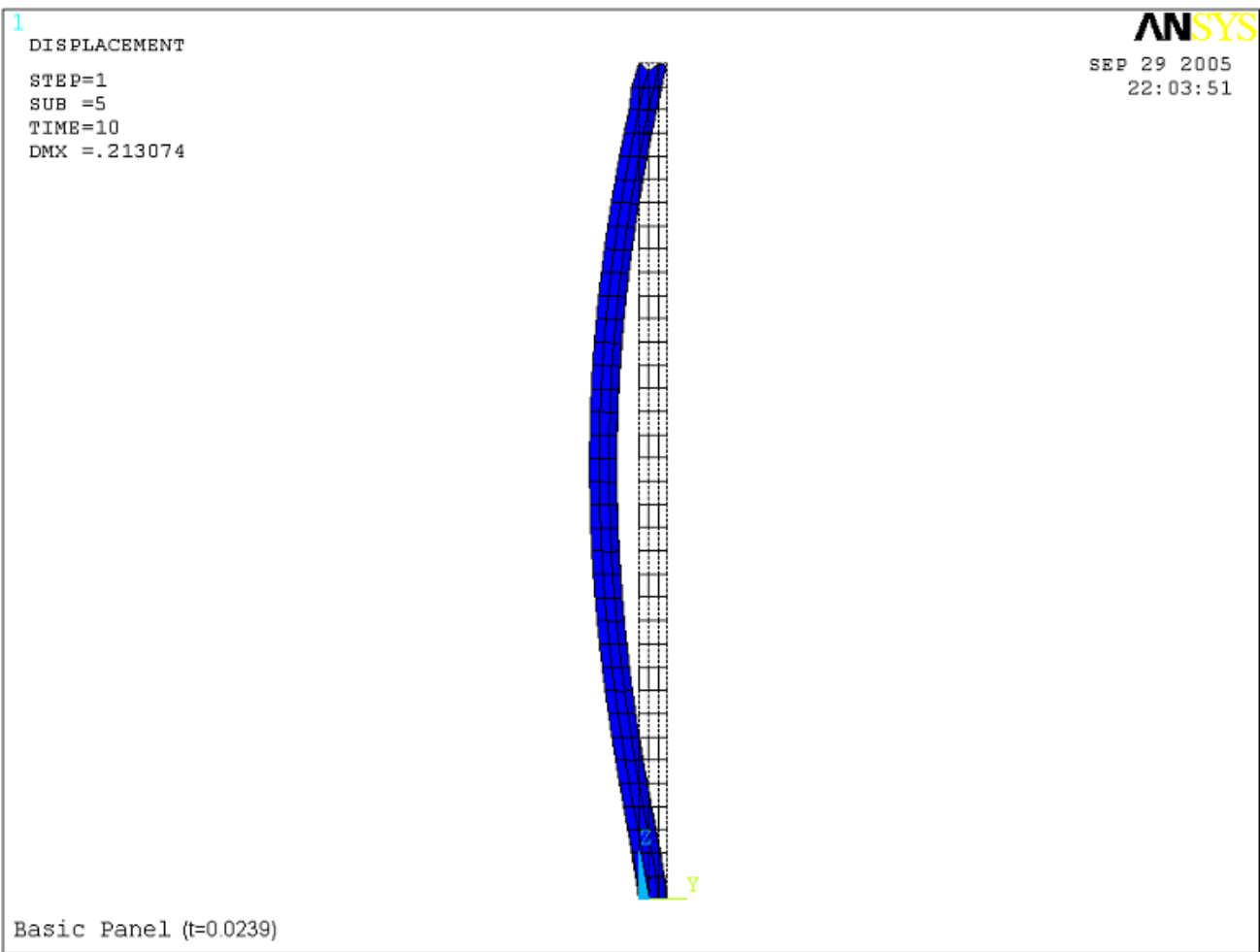

Figure 3.6 Deformation of the panel with 24 Gage (unit: inches) 


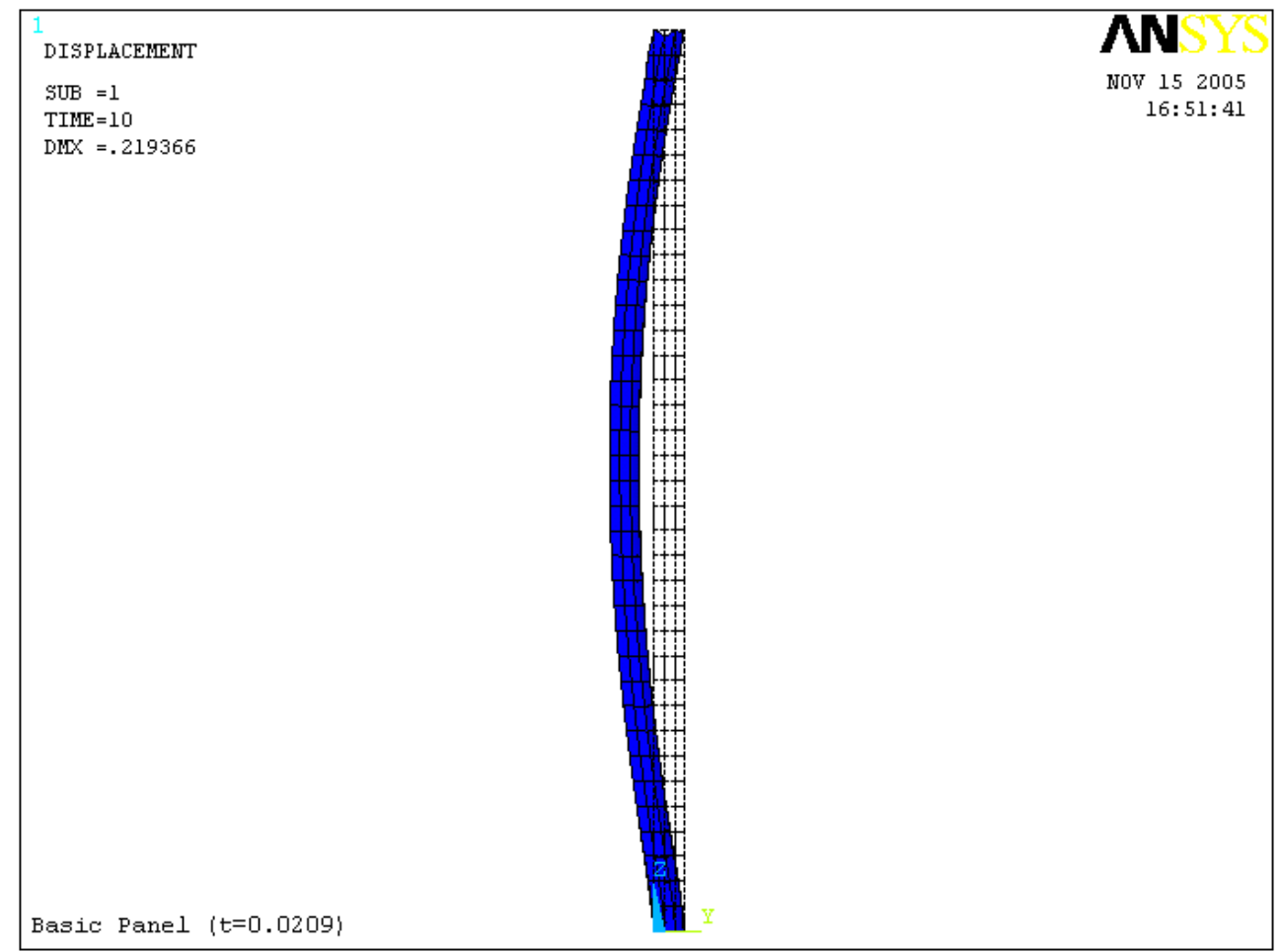

Figure 3.7 Deformation of the panel with 25 Gage (unit: inches)

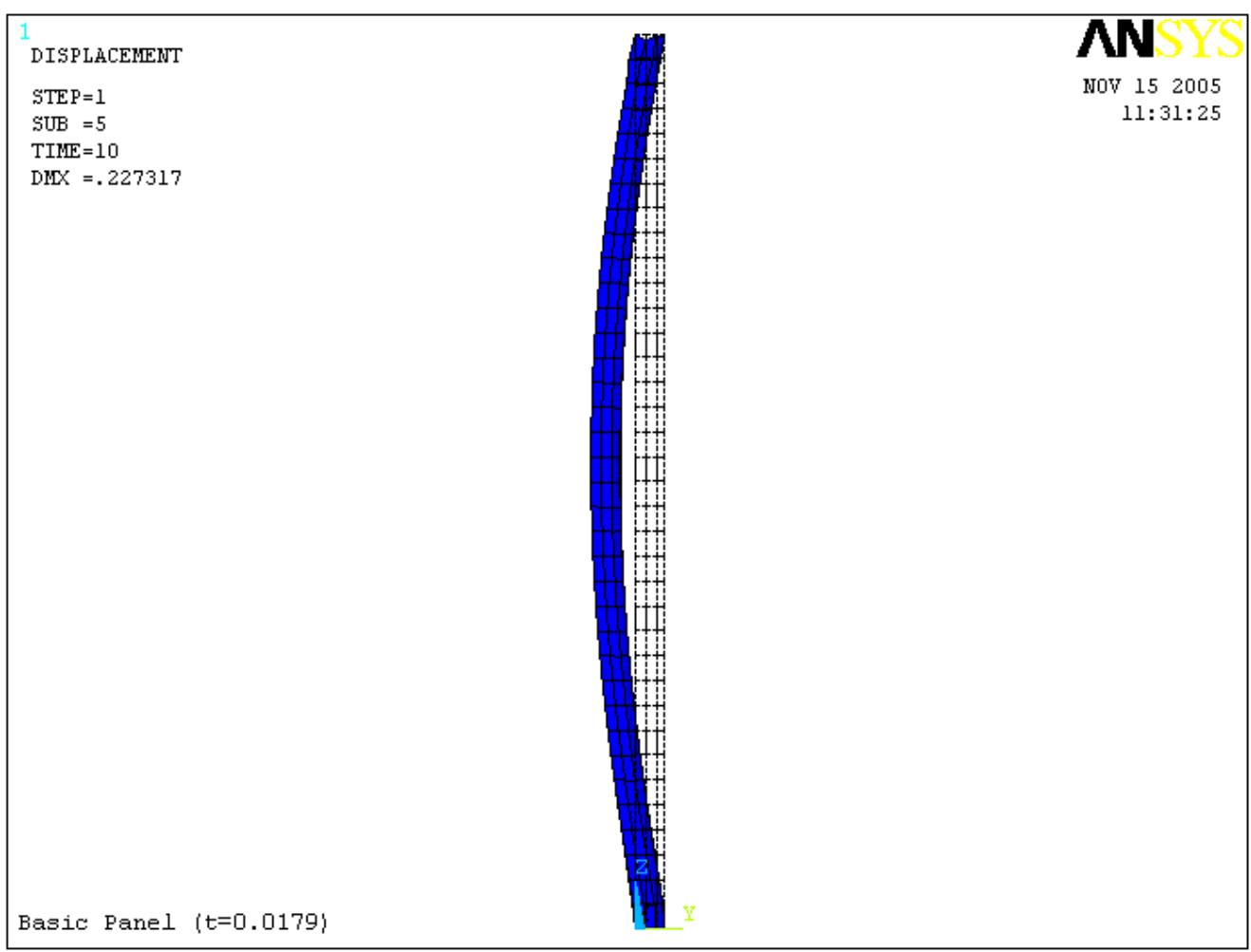

Figure 3.8 Deformation of the panel with 26 Gage (unit: inches) 


\subsubsection{Stress and strain}

Figures 3.9 through 3.14 show the stresses in steel facings of the panels and Figures 3.15 through 3.20, show the stresses in the longitudinal direction (z direction) in foam of the panels. The panels were composed of 24,25 or 26 gage steel facings. The panel stresses were presented in the format of stress contours. The stress values in steel facings and foams were shown in the stress value bar that matched with the color in the contour.

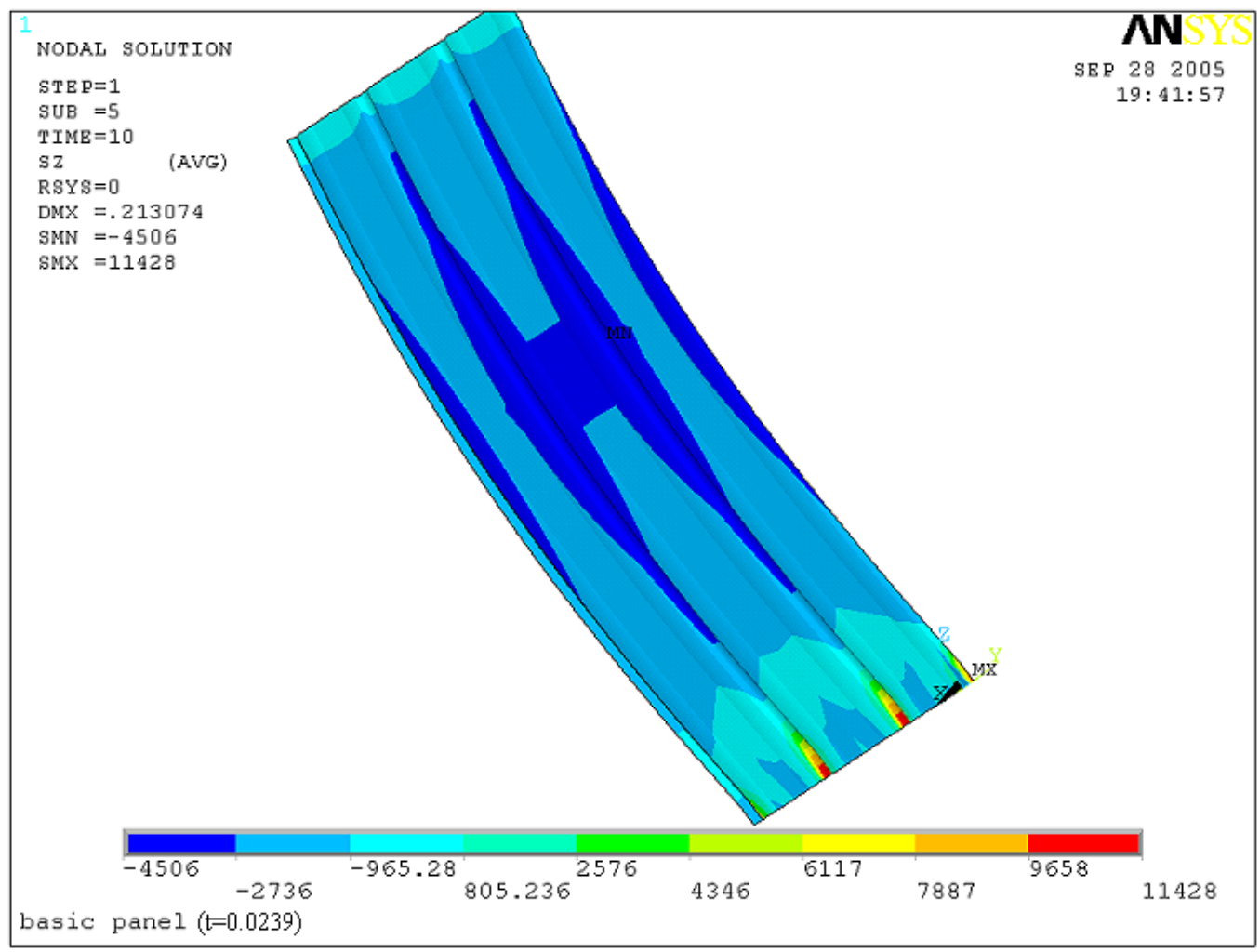

Figure 3.9 Stresses in $\mathrm{z}$ direction in the front steel facing with 24 Gage (unit: psi) 


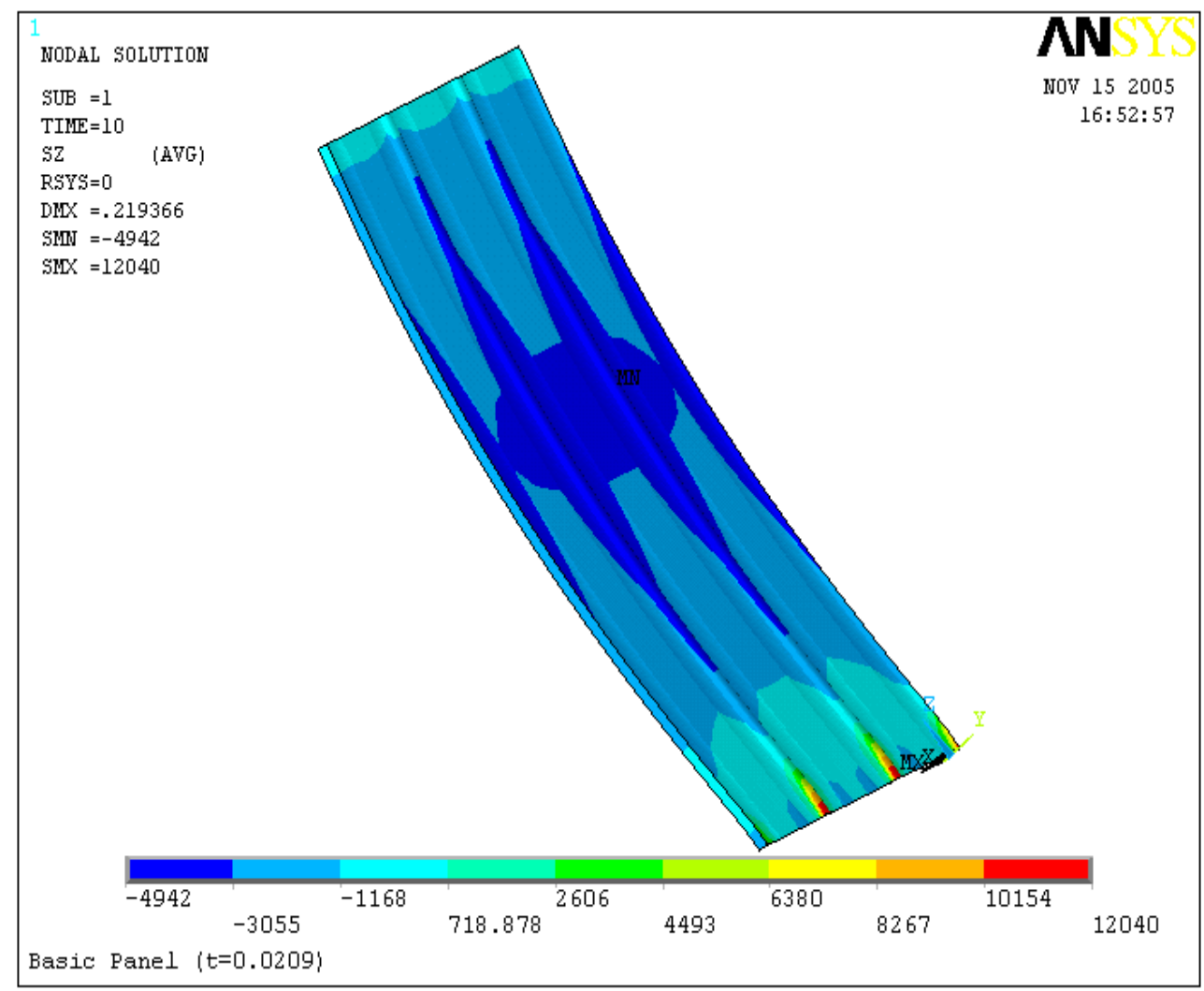

Figure 3.10 Stresses in $\mathrm{z}$ direction in the front steel facing with 25 Gage (unit: psi)

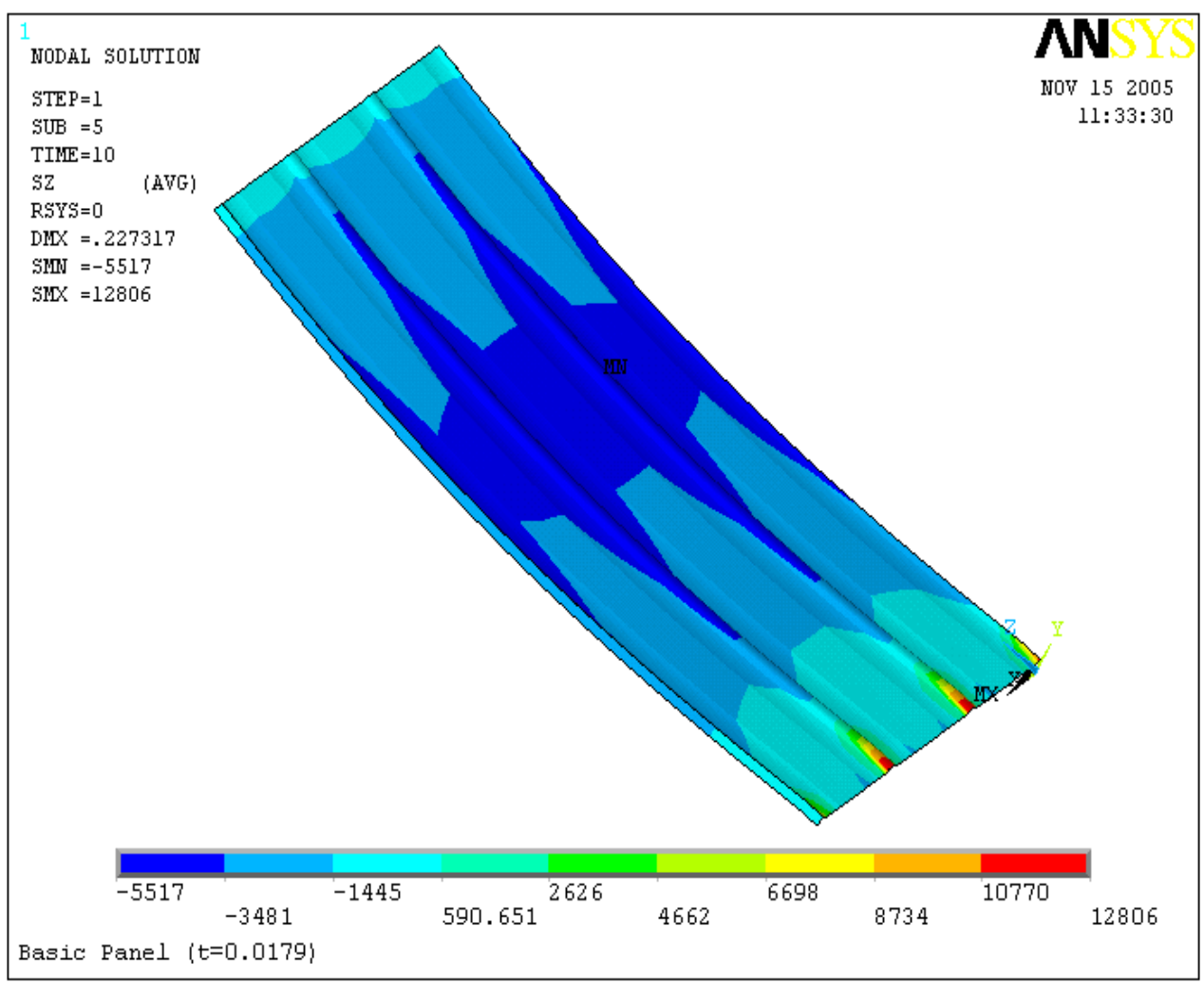

Figure 3.11 Stresses in $\mathrm{z}$ direction in the front steel facing with 26 Gage (unit: psi) 


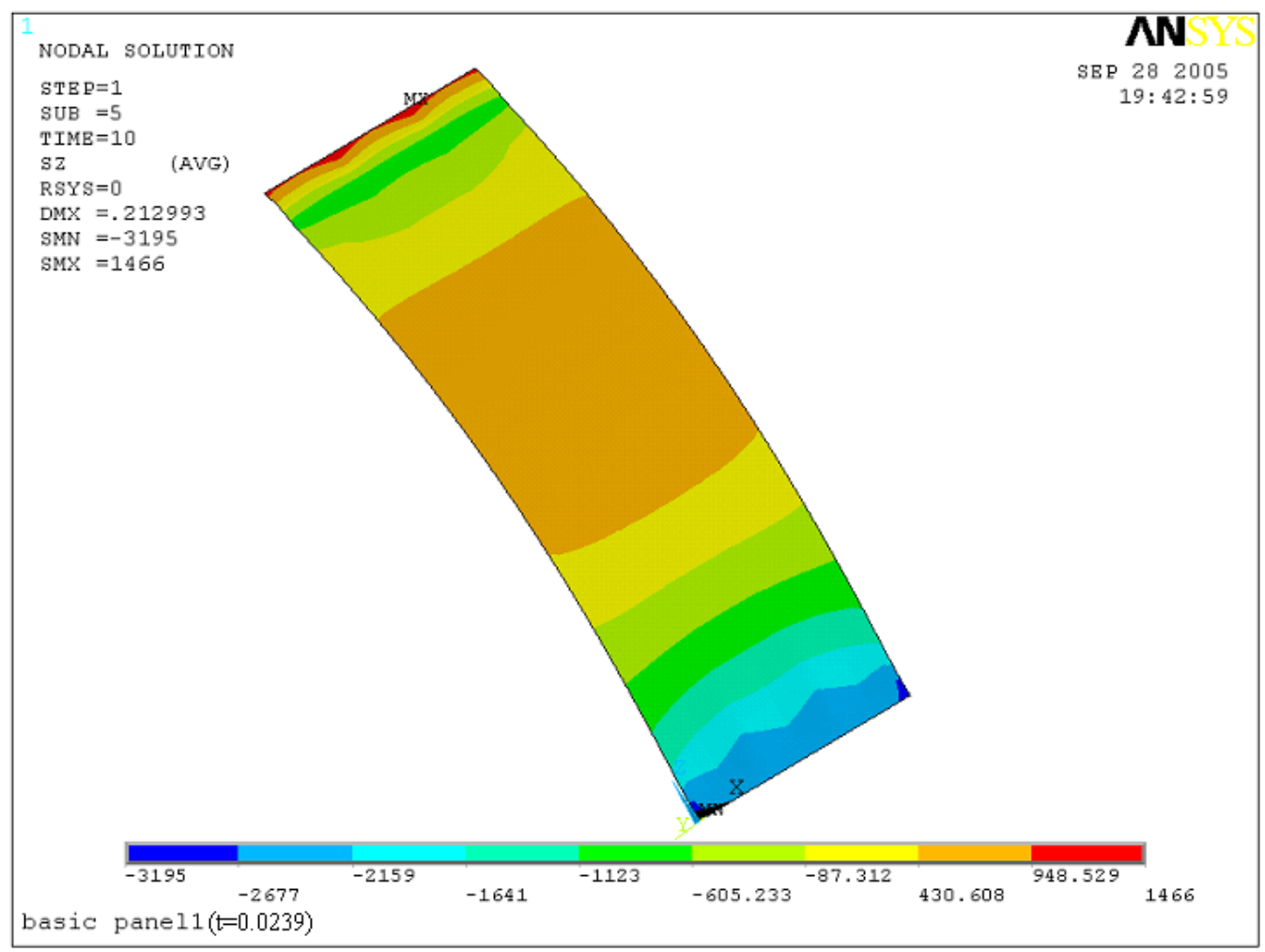

Figure 3.12 Stresses in $\mathrm{z}$ direction in the back steel facing with 24 Gage (unit: psi)

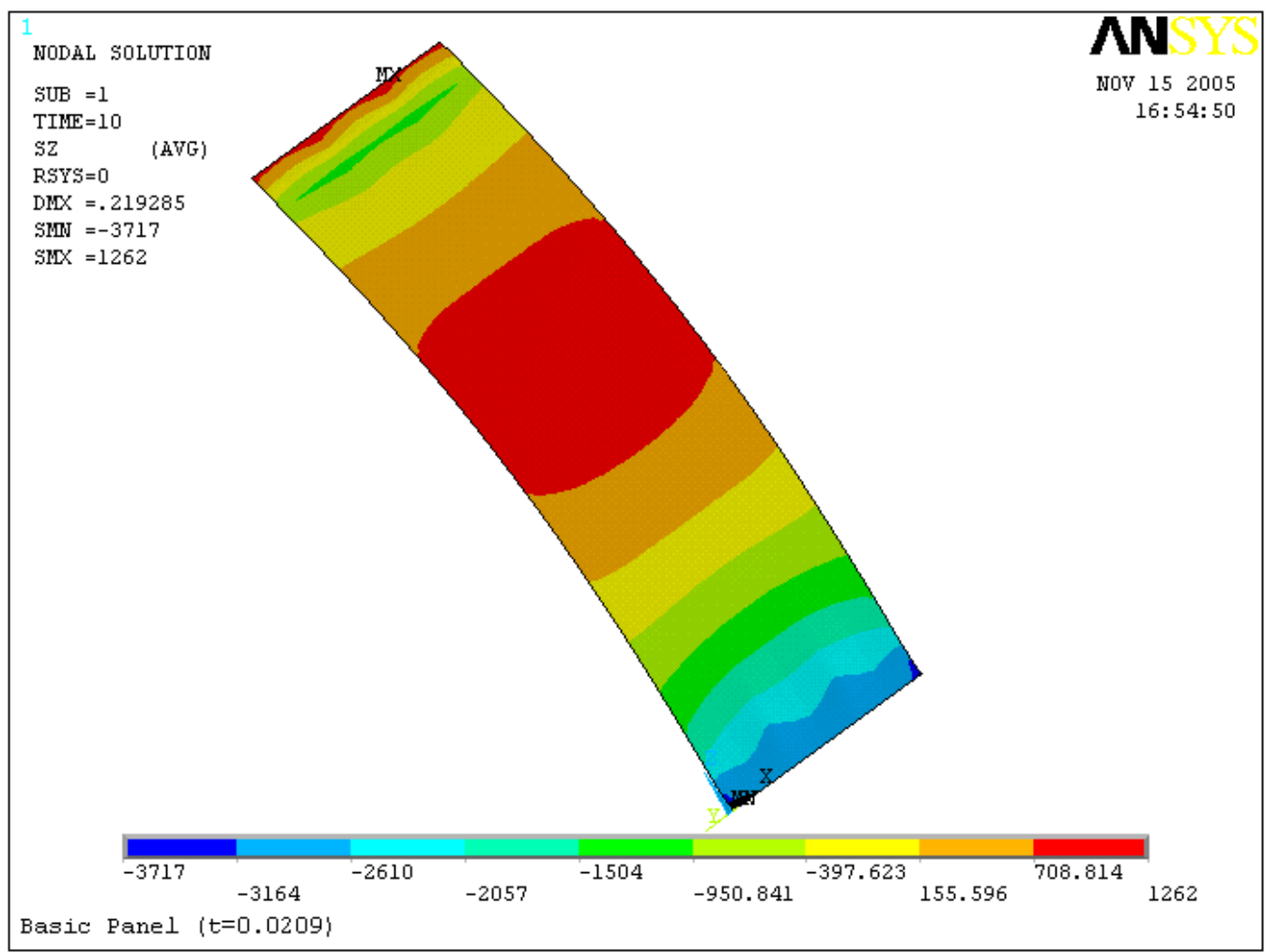

Figure 3.13 Stresses in $\mathrm{z}$ direction in the back steel facing with 25 Gage (unit: psi) 


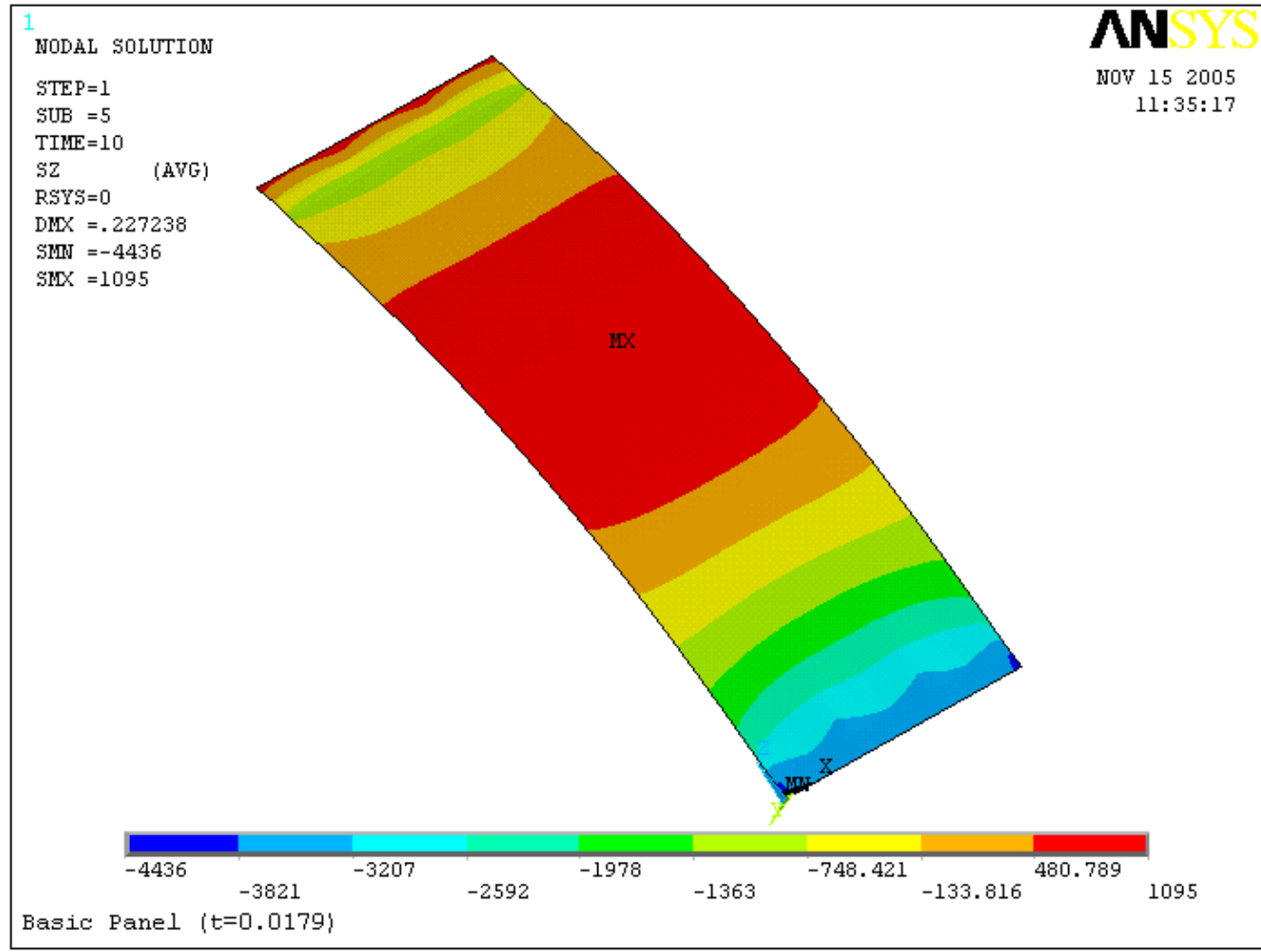

Figure 3.14 Stresses in $\mathrm{z}$ direction in the back steel facing with 26 Gage (unit: psi)

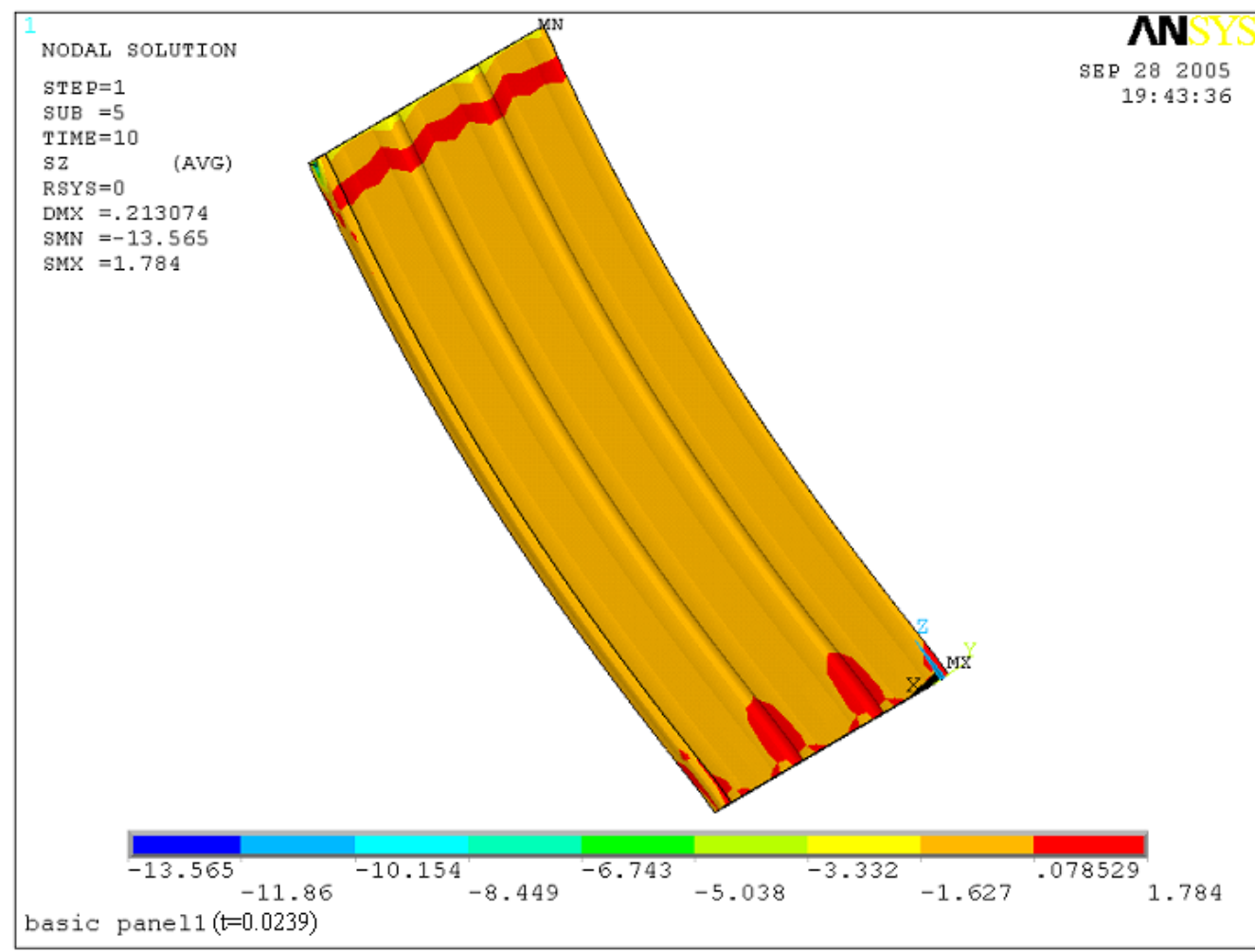

Figure 3.15 Stresses in $\mathrm{z}$ direction in the front side of foam with 24 Gage (unit: psi) 


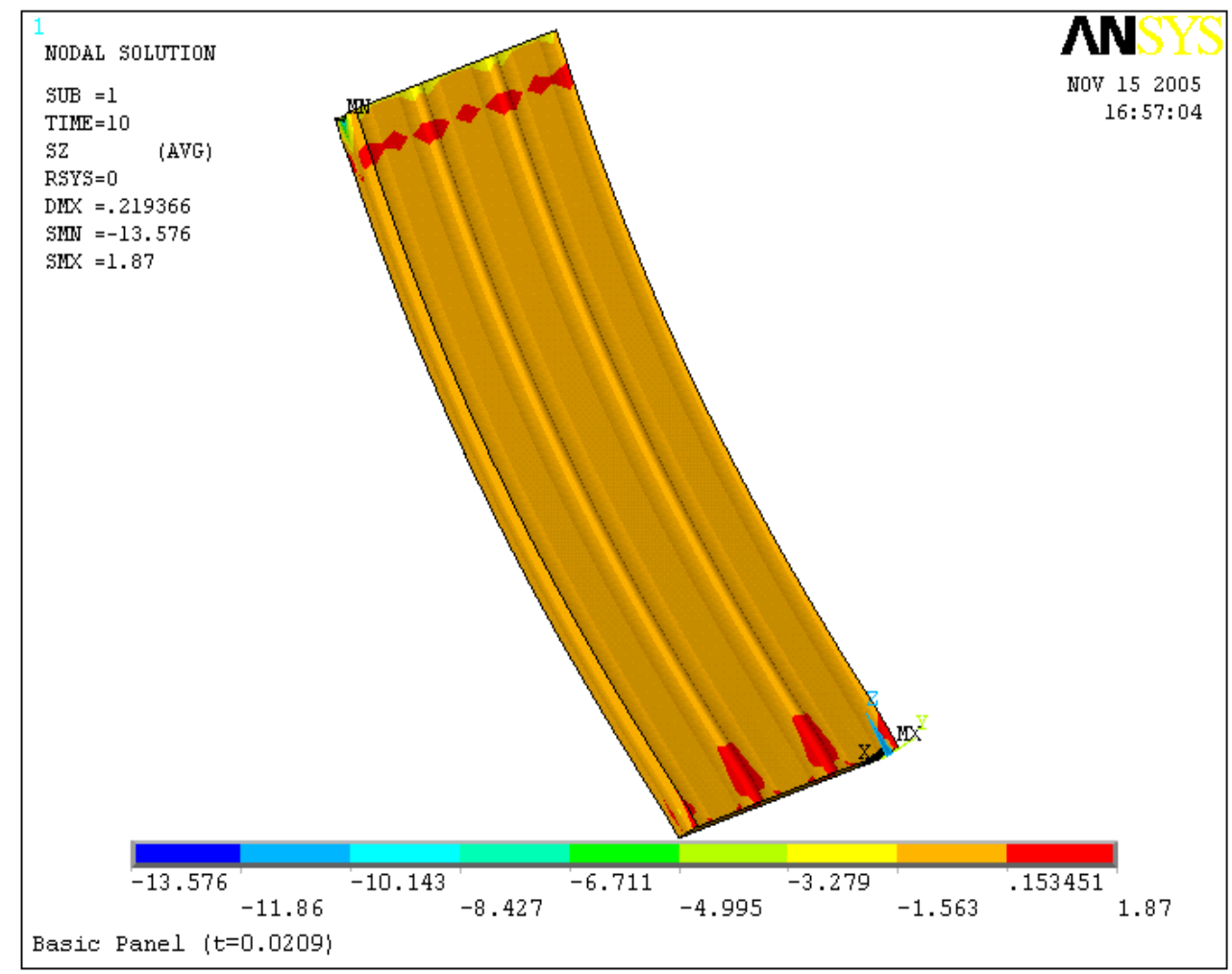

Figure 3.16 Stresses in $\mathrm{z}$ direction in the front side of foam with 25 Gage (unit: psi)

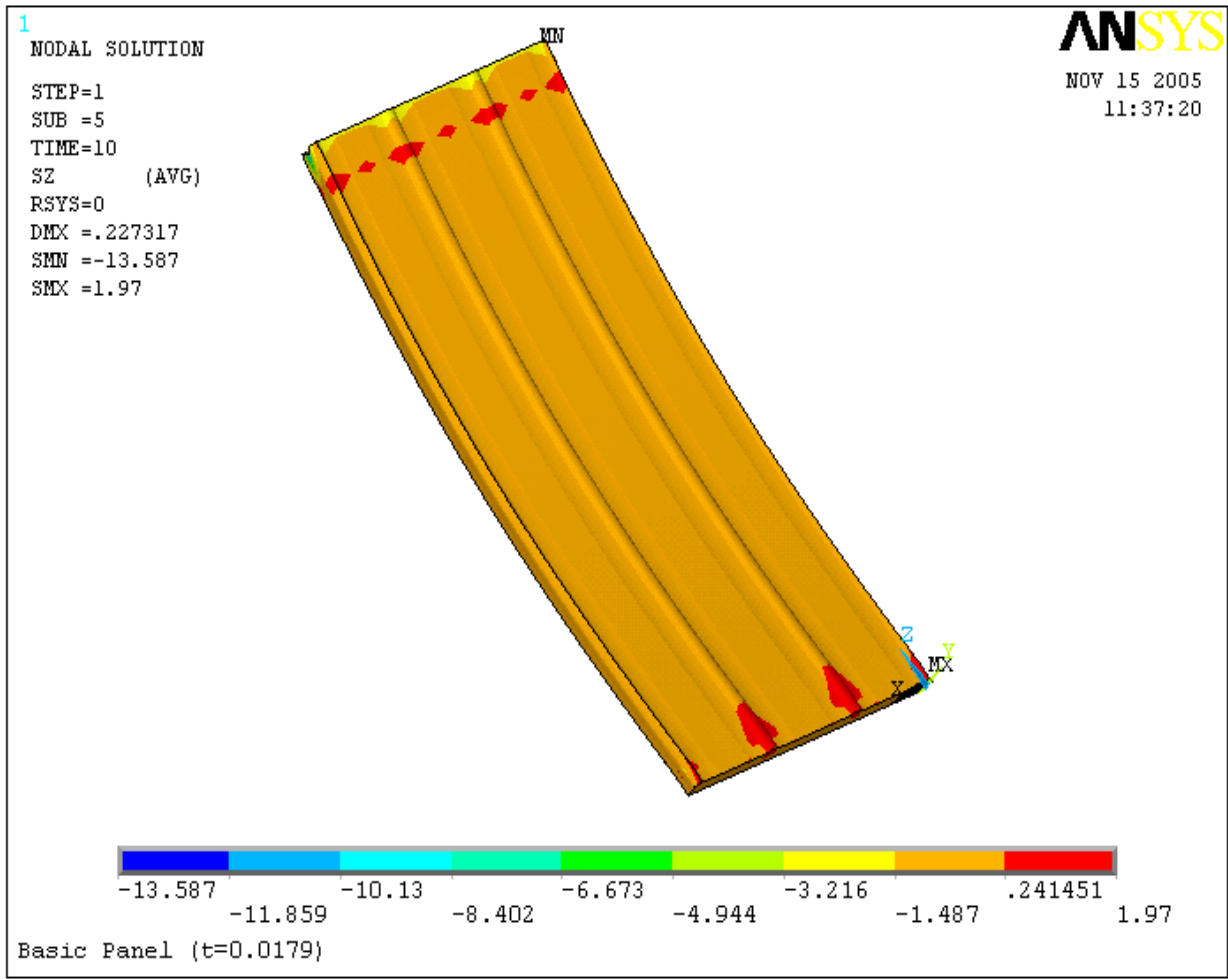

Figure 3.17 Stresses in $\mathrm{z}$ direction in the front side of foam with 26 Gage (unit: psi) 


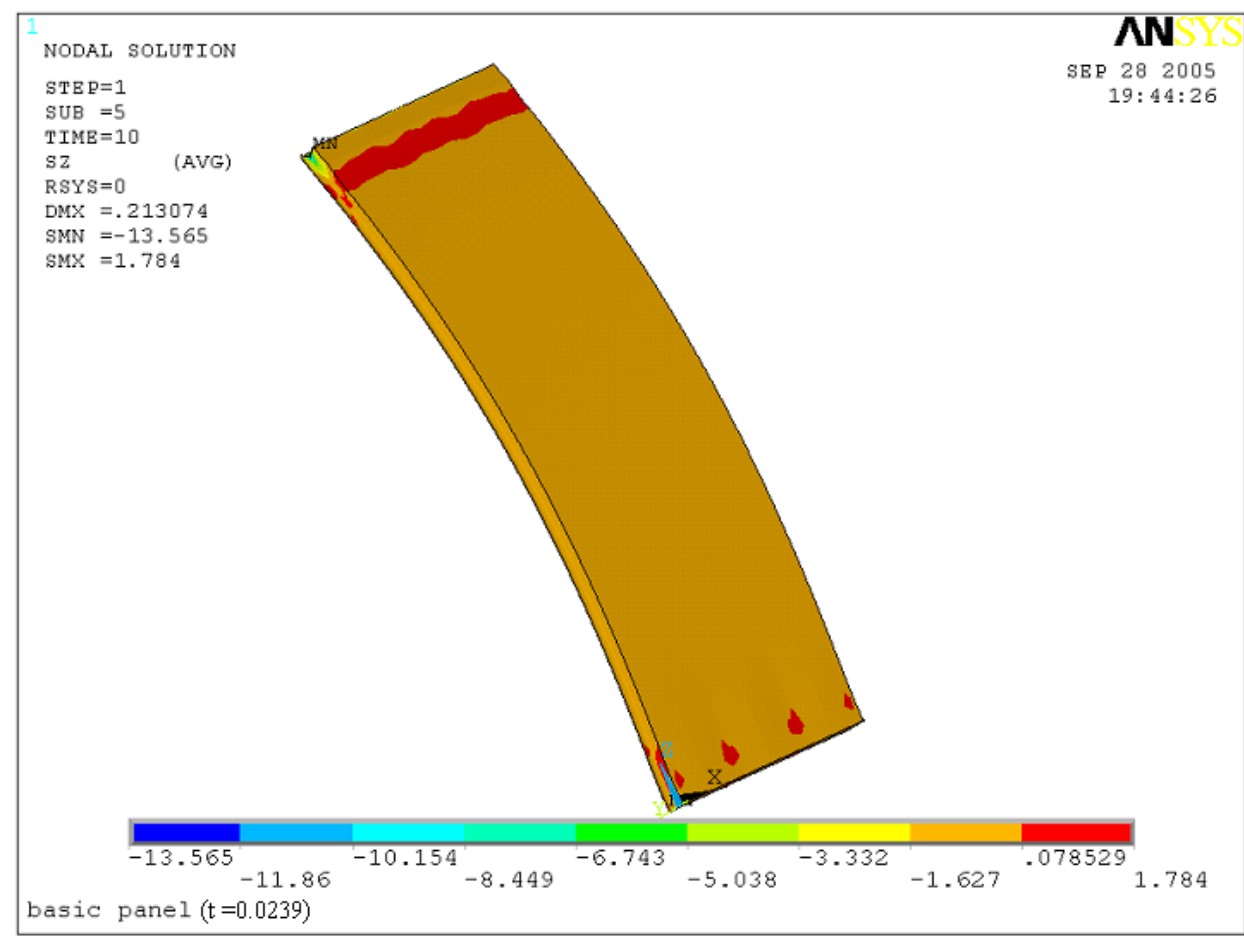

Figure 3.18 Stresses in $\mathrm{z}$ direction in the back side of foam with 24 Gage (unit: psi)

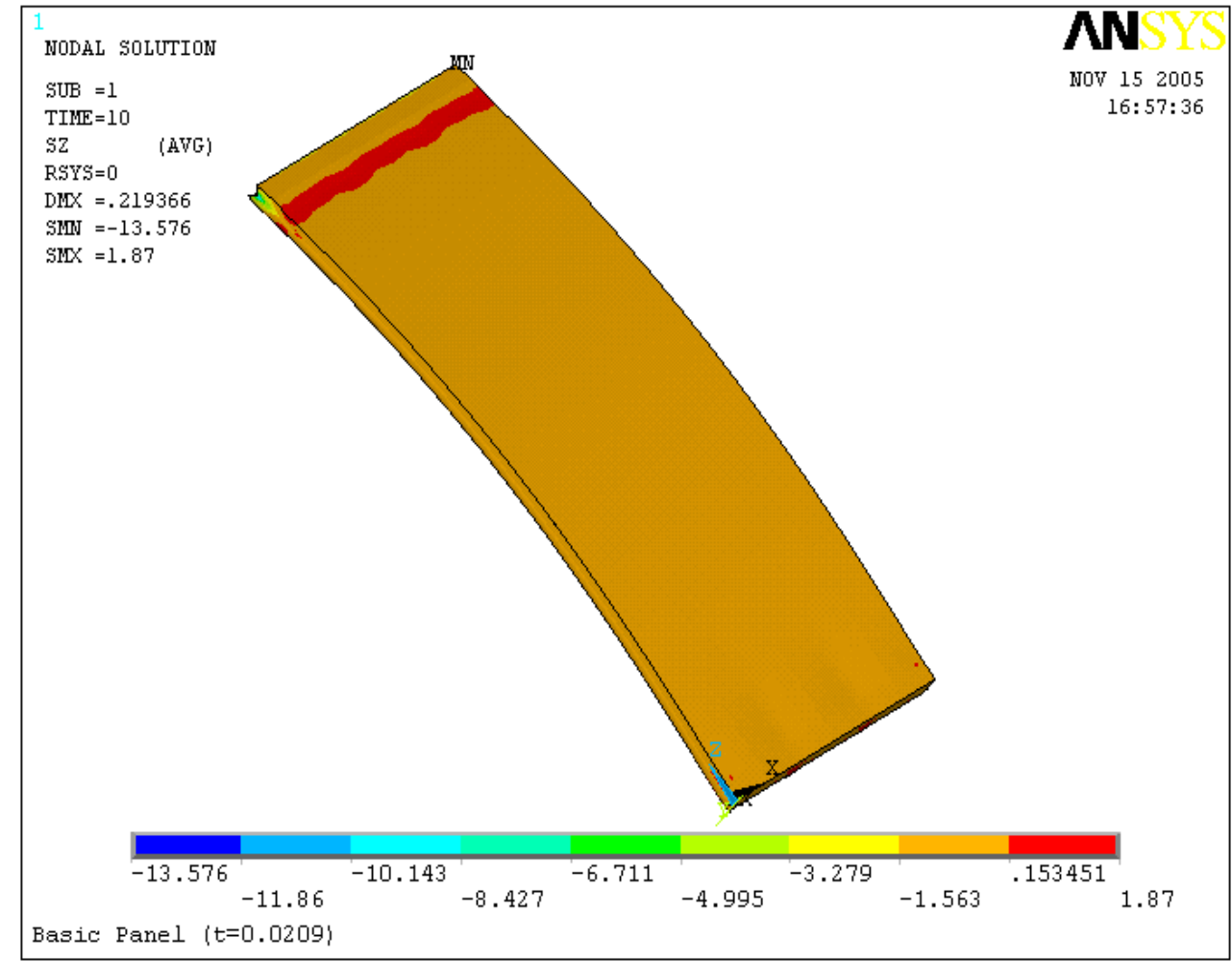

Figure 3.19 Stresses in $\mathrm{z}$ direction in the back side of foam with 25 Gage (unit: psi) 


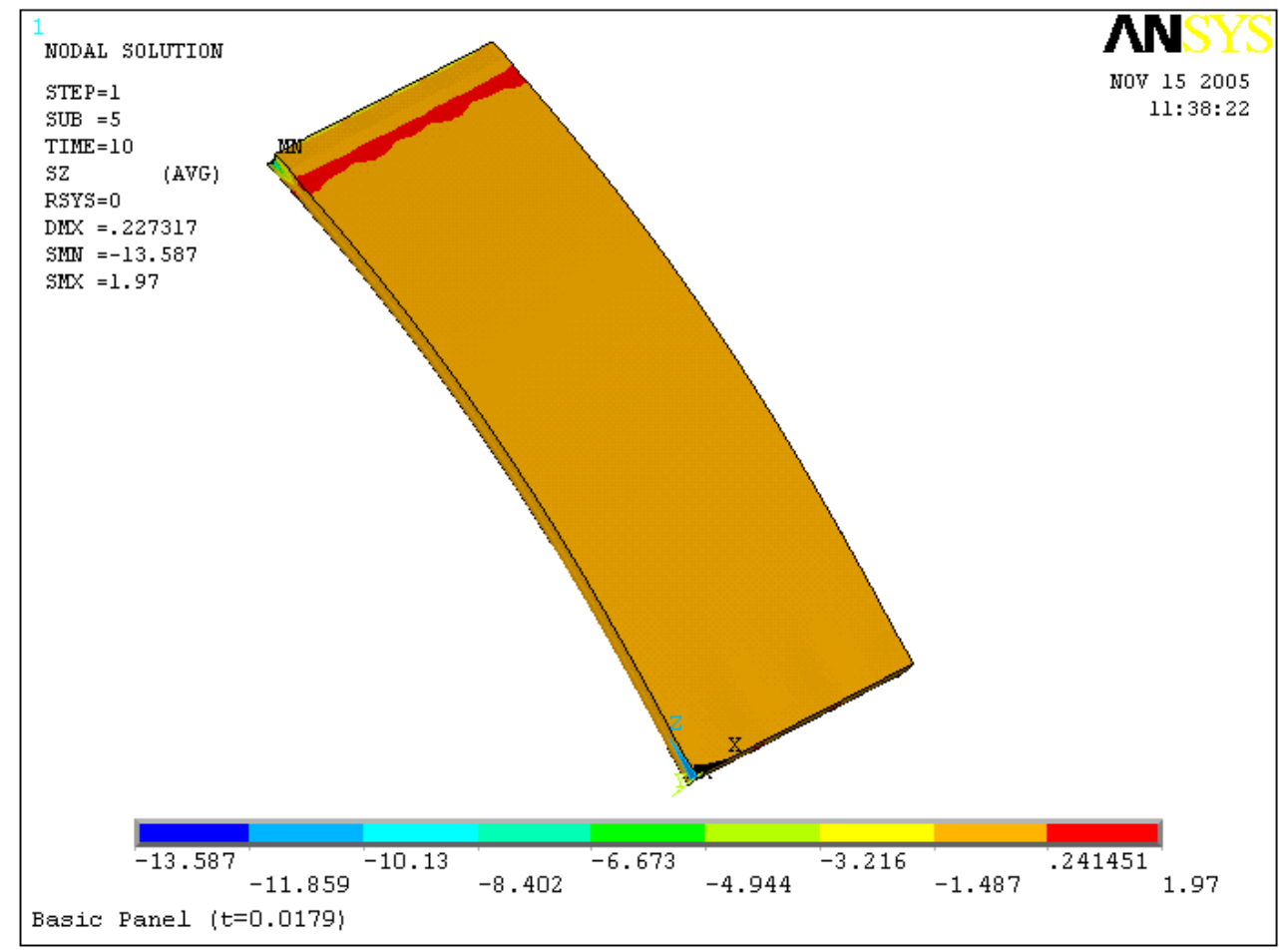

Figure 3.20 Stresses in $\mathrm{z}$ direction in the back side of foam with 26 Gage (unit: psi)

\subsection{Results Comments of the Sandwich Panels}

(a) The maximum deformations and stresses of the panels studied are listed in Table 3.2

Table 3.2 Summary of the maximum deformation and stresses of the panels

\begin{tabular}{cccccccc}
\hline & & \multicolumn{3}{c}{$\begin{array}{c}\text { Maximum positive stress } \\
\text { (Tension) (psi) }\end{array}$} & \multicolumn{3}{c}{$\begin{array}{c}\text { Maximum negative stress } \\
\text { (Compression) (psi) }\end{array}$} \\
\cline { 3 - 8 } Gage\# & $\begin{array}{c}\text { Maximum } \\
\text { Deformatio } \\
\text { n(in.) }\end{array}$ & $\begin{array}{c}\text { Steel } \\
\text { sheet } \\
\text { (front) }\end{array}$ & $\begin{array}{c}\text { Steel sheet } \\
\text { (back) }\end{array}$ & $\begin{array}{c}\text { PU } \\
\text { foam }\end{array}$ & $\begin{array}{c}\text { Steel } \\
\text { sheet } \\
\text { (front) }\end{array}$ & $\begin{array}{c}\text { Steel } \\
\text { sheet } \\
\text { (back) }\end{array}$ & $\begin{array}{c}\text { PU } \\
\text { foam }\end{array}$ \\
\hline Gage 24 & 0.213 & 11428 & 1466 & 1.784 & 4506 & 3195 & 13.565 \\
\hline Gage 25 & 0.219 & 12040 & 1262 & 1.87 & 4942 & 3717 & 13.576 \\
\hline Gage 26 & 0.227 & 12806 & 1095 & 1.97 & 5517 & 4436 & 13.587 \\
\hline
\end{tabular}

(b) For the panel of 24, 25 and 26 gage, the maximum deformation occurred at about 51"

from the top surface. The maximum tensile stress in longitudinal direction occurred at the bottom of the front steel facing, while the maximum compressive stress occurred at about 45" from the top surface of the front steel facing. 
(c) The magnitude of deformation was dependent on the modulus of elasticity of foam, $E_{\text {foam }}$, as shown in Figure 3.21 through 3.23.

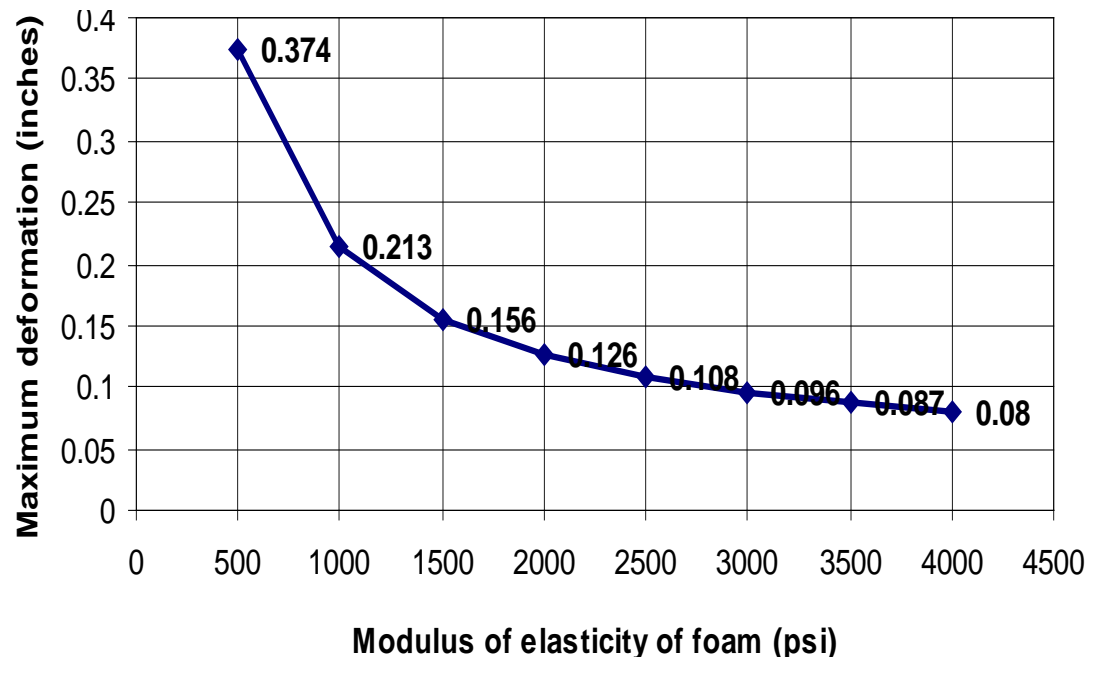

Figure 3.21 Maximum deformation of panel vs. modulus of elasticity of foam (24 Gage)

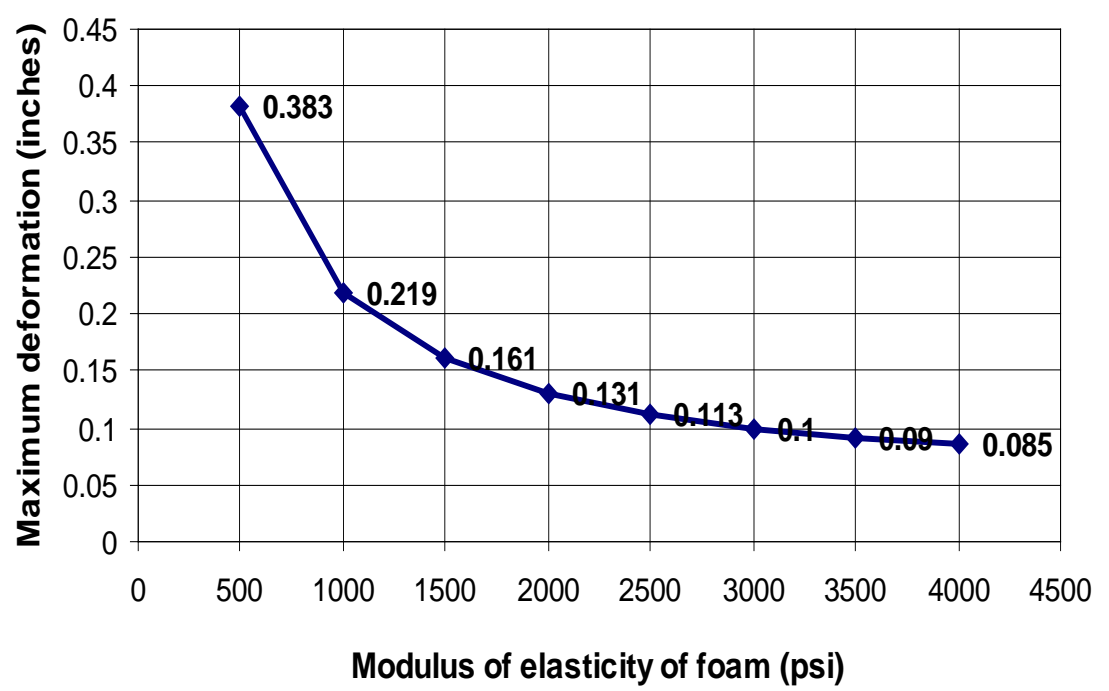

Figure 3.22 Maximum deformation of panel vs. modulus of elasticity of foam (25 Gage) 


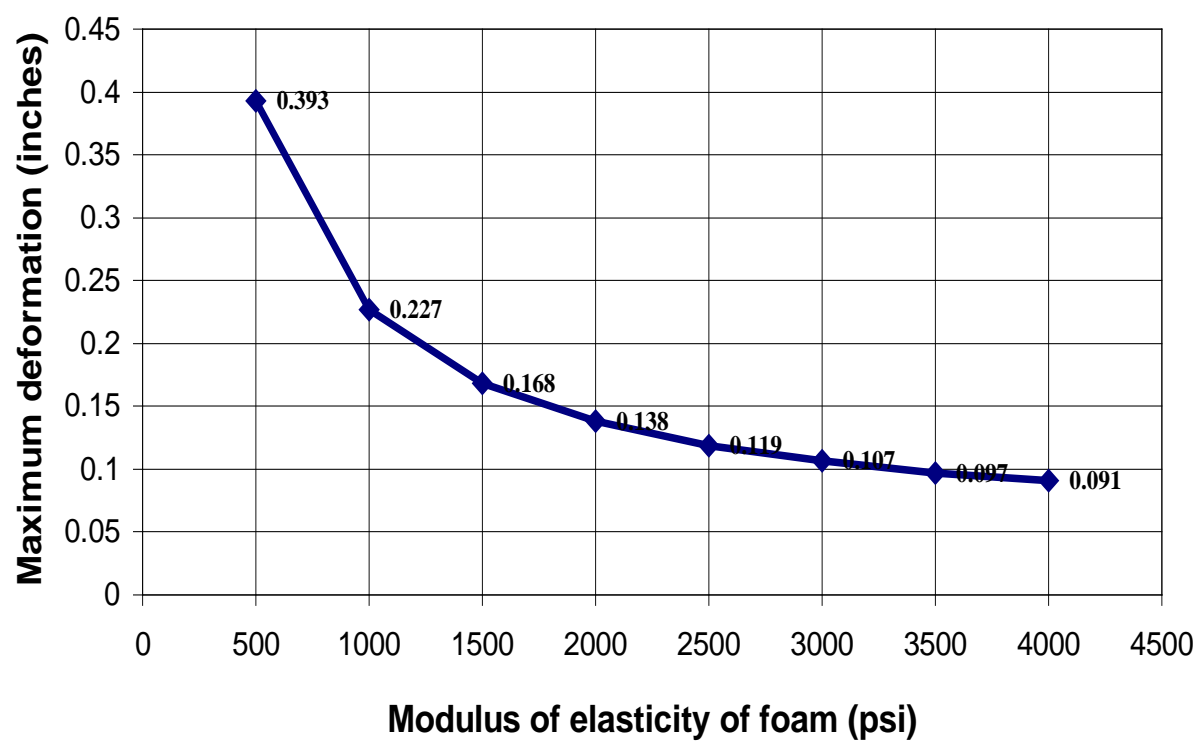

Figure 3.23 Maximum deformation of panel vs. modulus of elasticity of foam (26 Gage)

\subsection{Load Capability of the Basic Sandwich Panel}

The load capabilities of the panel were determined from the following factored combinations:

$1.2 \mathrm{D}+1.6 \mathrm{~L}+0.5\left(\mathrm{~L}_{\mathrm{r}}\right.$ or $\mathrm{S}$ or $\left.\mathrm{R}\right)$

$1.2 \mathrm{D}+1.6\left(\mathrm{~L}_{\mathrm{r}}\right.$ or $\mathrm{S}$ or $\left.\mathrm{R}\right)+(0.5 \mathrm{~L}$ or $0.8 \mathrm{~W})$

$1.2 \mathrm{D}+1.6 \mathrm{~W}+0.5 \mathrm{~L}+0.5\left(\mathrm{~L}_{\mathrm{r}}\right.$ or $\mathrm{S}$ or $\left.\mathrm{R}\right)$

Where $\mathrm{D}=$ dead load; $\mathrm{L}$ = live load due to occupancy; $\mathrm{Lr}=$ roof live load; $\mathrm{S}=$ snow load; $\mathrm{R}$ = nominal load due to initial rainwater or ice exclusive of the ponding contribution; and $\mathrm{W}=$ wind load

The initial values of the above loads are: $\mathrm{L}=12.340 \mathrm{psi} ; \mathrm{Lr}=4.930 \mathrm{psi}$; $\mathrm{S}=4.930 \mathrm{psi}$; $\mathrm{R}=$ 7.400 psi; and $\mathrm{W}=0.136 \mathrm{psi}$

\subsubsection{Vertical load capability of the basic panels}

Vertical load capability of the panels was determined based on load combination (2) $1.2 \mathrm{D}+1.6 \mathrm{R}+0.8 \mathrm{~W}$. The dead load and wind load remained unchanged in the analysis; the only 
variable was the vertical rain load. The maximum vertical load was controlled by the allowable compressive stresses in the foam.

Table 3.3 Vertical load capability (Rain load) of the basic panel

\begin{tabular}{|c|c|c|c|c|c|}
\hline \multirow[b]{2}{*}{$\begin{array}{c}\text { Steel } \\
\text { thickness }\end{array}$} & \multirow[b]{2}{*}{$\mathbf{R}(\mathbf{p s i})$} & \multicolumn{2}{|c|}{ Stress in foam(psi) } & \multicolumn{2}{|c|}{ Stress in steel (ksi) } \\
\hline & & $\begin{array}{l}\text { Maximum } \\
\text { positive } \\
\text { stress } \\
\text { (Tension) }\end{array}$ & $\begin{array}{l}\text { Maximum } \\
\text { negative stress } \\
\text { (Compression) }\end{array}$ & $\begin{array}{l}\text { Maximum } \\
\text { positive } \\
\text { stress } \\
\text { (Tension) }\end{array}$ & $\begin{array}{l}\text { Maximum } \\
\text { negative stress } \\
\text { (Compression) }\end{array}$ \\
\hline 24 Gage & 40.58 & 5.136 & 50.990 & 5.98 & 9.43 \\
\hline 25 Gage & 40.54 & 5.037 & 50.988 & 6.027 & 9.22 \\
\hline 26 Gage & 40.51 & 4.943 & 50.997 & 6.037 & 9.349 \\
\hline
\end{tabular}

\subsubsection{Wind load capability of the basic panels}

Wind load capability of the panels was determined based on load combination (3) -

1.2D+1.6W+0.5L+0.5S. In this analysis, the dead load, live load and roof live load were constant.

The only variable was wind load. The wind load capacity was controlled by the allowable steel tensile stress.

Table 3.4 Horizontal load capability (Wind load) of the basic panel

\begin{tabular}{cccccc}
\hline \multirow{2}{*}{$\begin{array}{c}\text { Steel } \\
\text { thickness }\end{array}$} & $\mathbf{W}(\mathbf{p s i})$ & $\begin{array}{c}\text { Maximum } \\
\text { positive stress } \\
\text { (Tension) }\end{array}$ & $\begin{array}{l}\text { Maximum } \\
\text { negative stress } \\
\text { (Compression) }\end{array}$ & $\begin{array}{c}\text { Maximum } \\
\text { positive stress } \\
\text { (Tension) }\end{array}$ & $\begin{array}{l}\text { Maximum } \\
\text { negative stress } \\
\text { (Compression) }\end{array}$ \\
\hline 24 Gage & $\mathbf{0 . 1 9 1 9}$ & 4.142 & 6.784 & $\mathbf{2 8 . 0 4 6}$ & 8.262 \\
\hline 25 Gage & $\mathbf{0 . 1 8 2}$ & 4.126 & 6.788 & $\mathbf{2 8 . 0 5 0}$ & 8.544 \\
\hline 26 Gage & $\mathbf{0 . 1 7 1 1}$ & 4.098 & 6.792 & $\mathbf{2 8 . 0 4 8}$ & 8.916 \\
\hline
\end{tabular}

Note: $1 . \phi F_{\text {foam }}=0.85 \times 60=51 p s i ; \phi F_{\text {steel }}=0.85 \times 33=28.05 \mathrm{ksi}$

2. Dead load, live load and snow load are constants.

\subsubsection{Deflection capability of the basic panels}

Deflection capability of the panels was determined based on service load combination 
$\mathrm{D}+\mathrm{W}+\mathrm{L}+\mathrm{S}$ (or Lr). Except for the wind load, all of the other loads were kept as constants. The maximum deformation was limited to a common accepted requirement for buildings (AISC LRFD Specifications). Under the maximum deformation, the tensile stress in steel facing was very close to the allowable stress.

Table 3.5 Deformation vs. wind load (W) of the basic panel

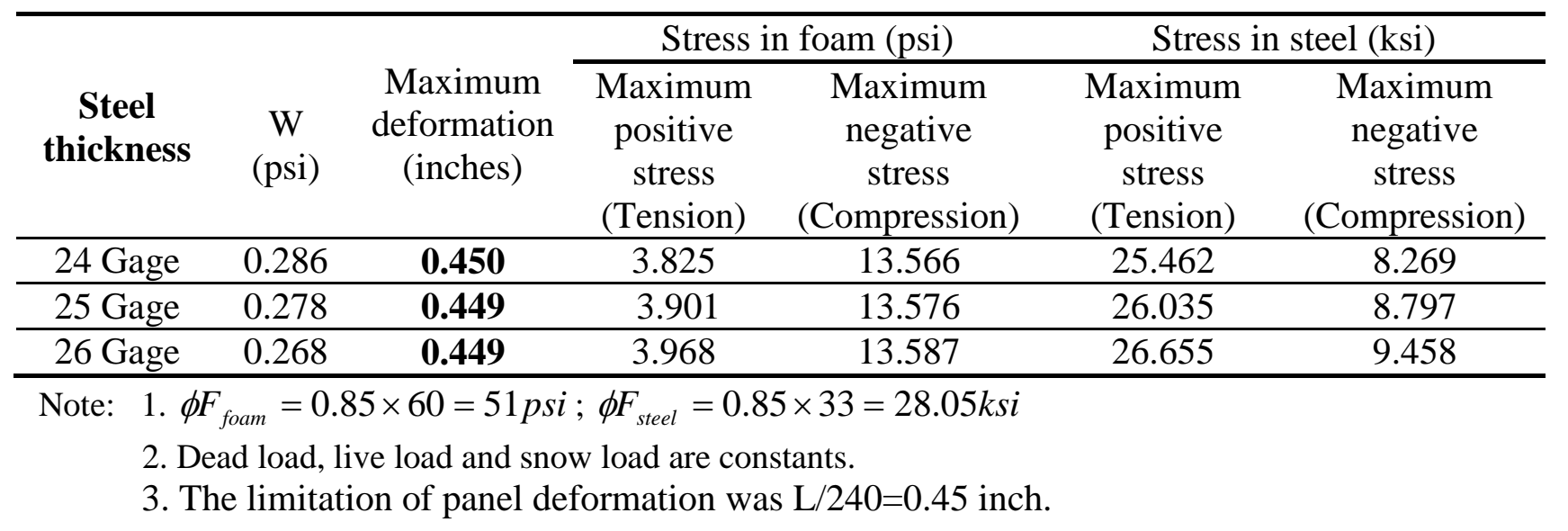





\section{CHAPTER 4}

\section{MODELING AND ANALYSIS OF C-SHAPE COLUMNS}

Three System columns of various cross-sections were studied for column performance. The three sections were C-shape profile, Delta-shape and original columns. In the Delta-shape column, both welded and non-welded cross sections were considered in the analysis. There were two sizes of the C-shape profiles $-2 \times 4$ channel (3.5 inch web) and $2 \times 6$ channel (5.5 inch web). In addition, various steel facing gages for all profiles were considered as described in chapter 2 . This chapter presents the study on C-shape profiles.

\subsection{Description of Input and Modeling of the C-shape Profiles}

\subsubsection{Dimensions and modeling of the C-shape profiles}

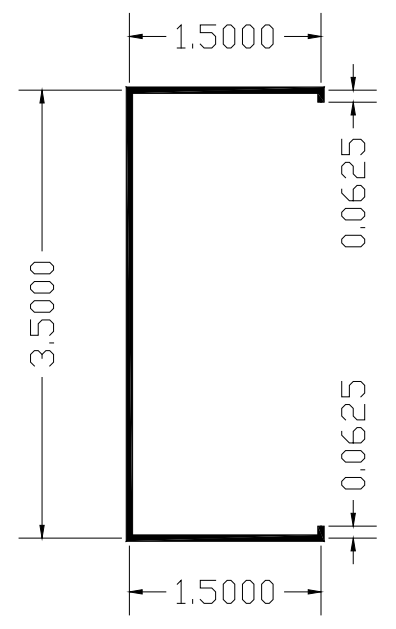

(a) $2 \times 4$

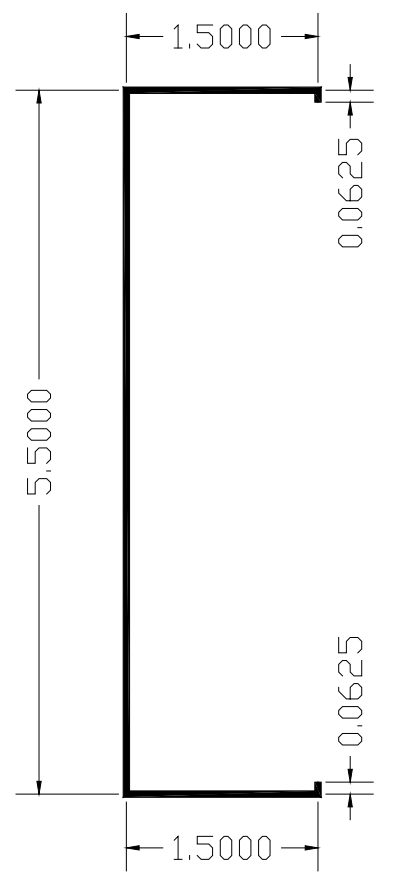

(b) $2 \times 6$

Figure 4.1 Cross-section of C-shape profile (unit: inches) 


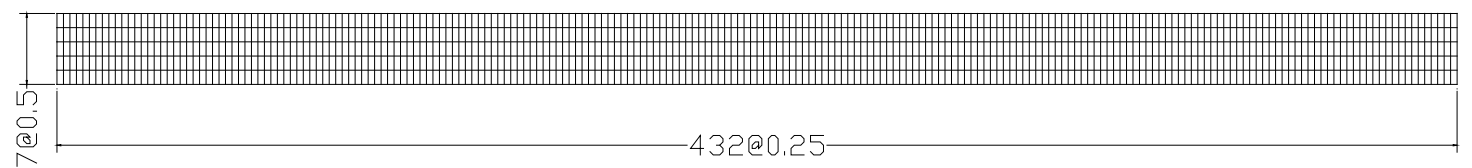

(a) Column with 2X4 C-shape

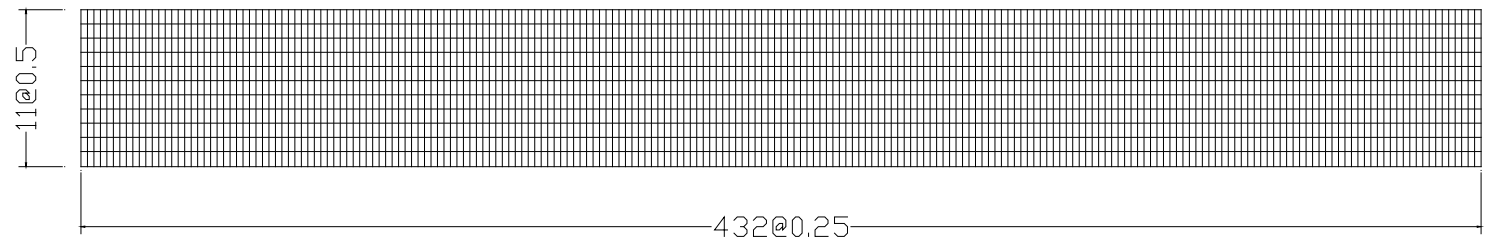

(b) Column with 2X6 C-shape

Figure 4.2 Modeling of C-shape profile

\subsubsection{Finite element model of column with C-shape Profile}

Shell elements (Shell181) were used to model the C-shape profile. Figure 4.3 shows the threedimensional view of the C-shape column model. The model was restrained with pin supports at the top of the column and fix supports at the bottom except the rotation about Y direction, as shown in Figure. 4.4

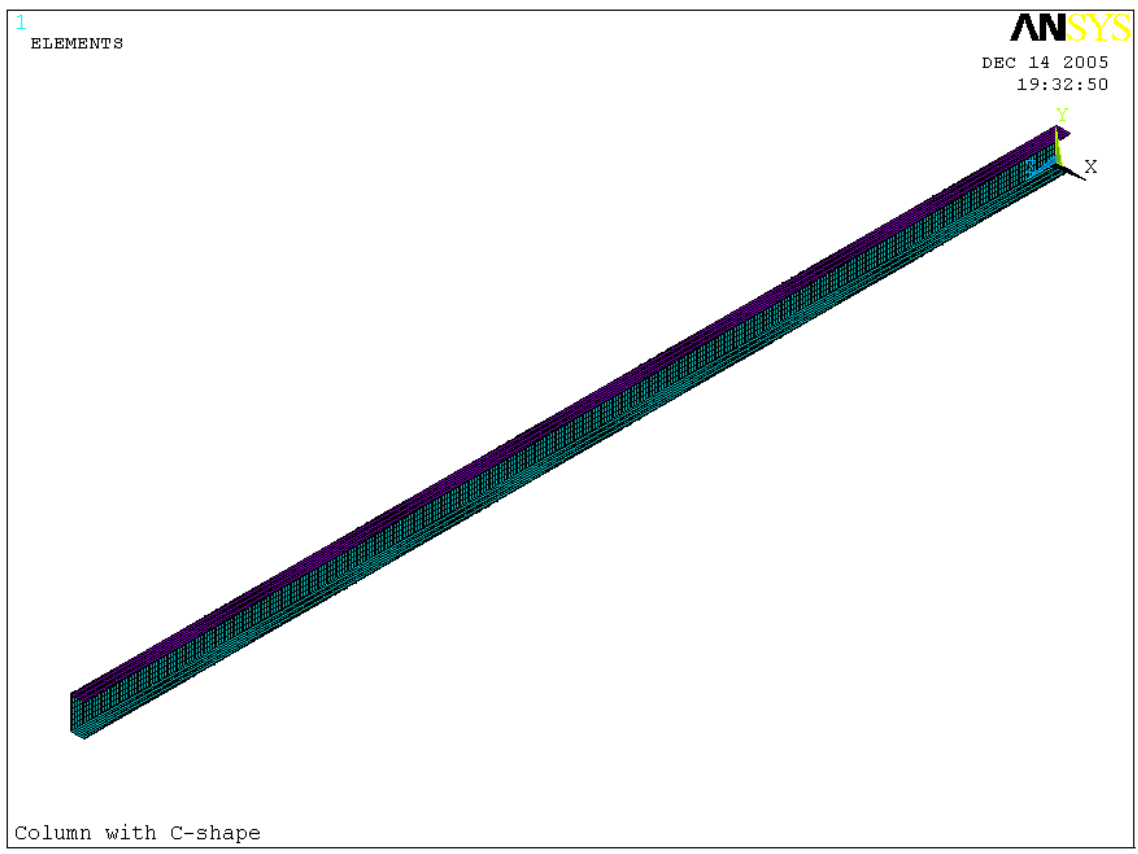

Figure 4.3 The 3-D C-shape profile model 


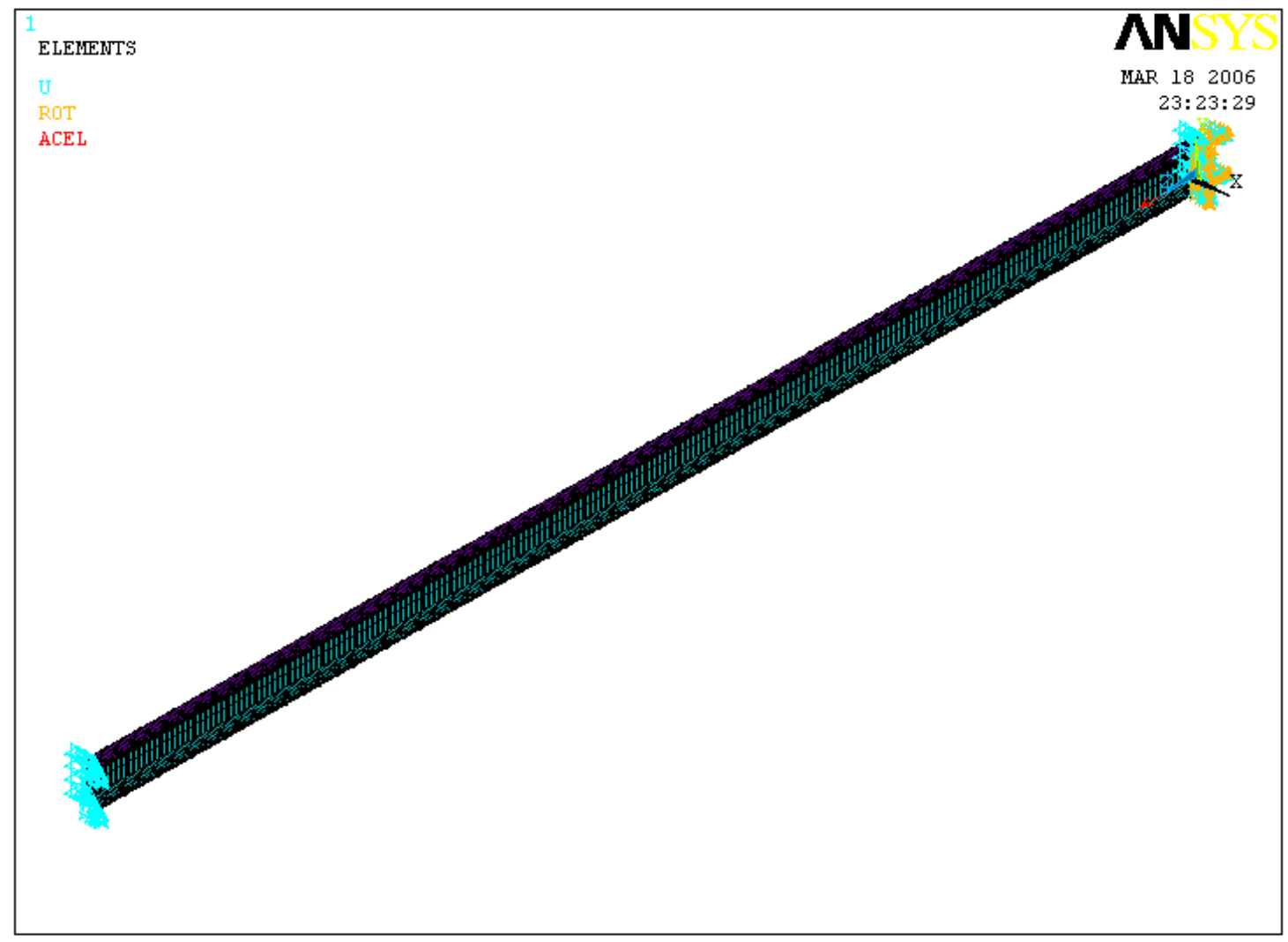

Figure 4.4 Model of the C-shape profile with end restrains

\subsubsection{Loads}

Table 4.1 Loading on the C-shape profiles

\begin{tabular}{cccccc}
\hline \multicolumn{2}{c}{ Gage \# } & \multirow{2}{*}{$\begin{array}{c}\text { Dead load } \\
\text { ( lbs) }\end{array}$} & $\begin{array}{c}\text { Live load } \\
\text { (lb/in) }\end{array}$ & \multicolumn{2}{c}{ Wind load(psi) } \\
\cline { 5 - 7 } Gage 16 & $2 \times 4$ & 12.13 & 192.022 & Case 1 & Case 2 \\
\cline { 2 - 6 } & $2 \times 6$ & 15.80 & 147.495 & 0.136 & 2.176 \\
\hline \multirow{2}{*}{ Gage 20 } & $2 \times 4$ & 7.28 & 192.022 & ---- & --176 \\
\cline { 2 - 6 } & $2 \times 6$ & 9.48 & 147.495 & --- & --- \\
\hline
\end{tabular}

Note:

1. Case 1 denotes columns carry the wind load based on the profile area only;

2. Case 2 denotes columns carry the wind load based on 24 in wide tributary area.

Figure 4.5 was an example of the C-shape profile with loads. It was assumed that the profile resists wind load on its flange. 


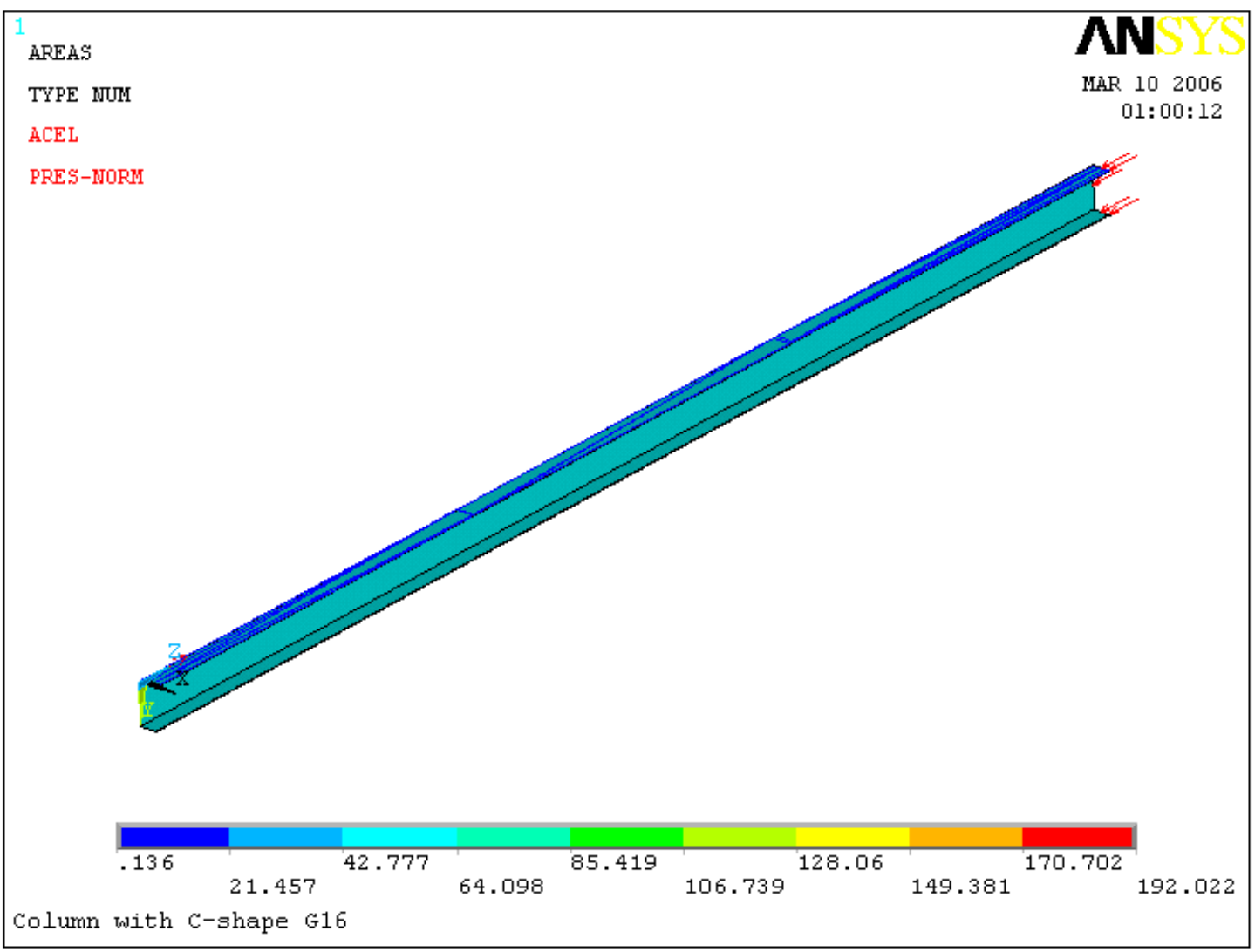

Figure 4.5 Loads on the C-shape profile

(Positive values denote the pressure act into the areas) 


\subsection{Analytical Results of the C-shape Profile}

\subsubsection{Deformation}

Figures 4.6 through 4.9 show the deformation summations of C-shape profiles with 16 gage and 20 gage under the load Case 1 . A large rotation was observed in the C-shape profiles when they were under loading. To show the rotation deformation, the column was cut at different longitudinal positions along the column. Figures 4.10 through 4.13 show the cross-sectional rotation of C-shape profiles with 16 gage and 20 gage under load Case 1. Similarly, Figures 4.14 and 4.15 show the deformation summations of the C-shape profiles with 16 gage under load Case 2 and Figures 4.16 through 4.17 shows the cross-sectional rotation of the columns under the same load case.

\subsubsection{Deformation of C-shape profile under the load Case 1}

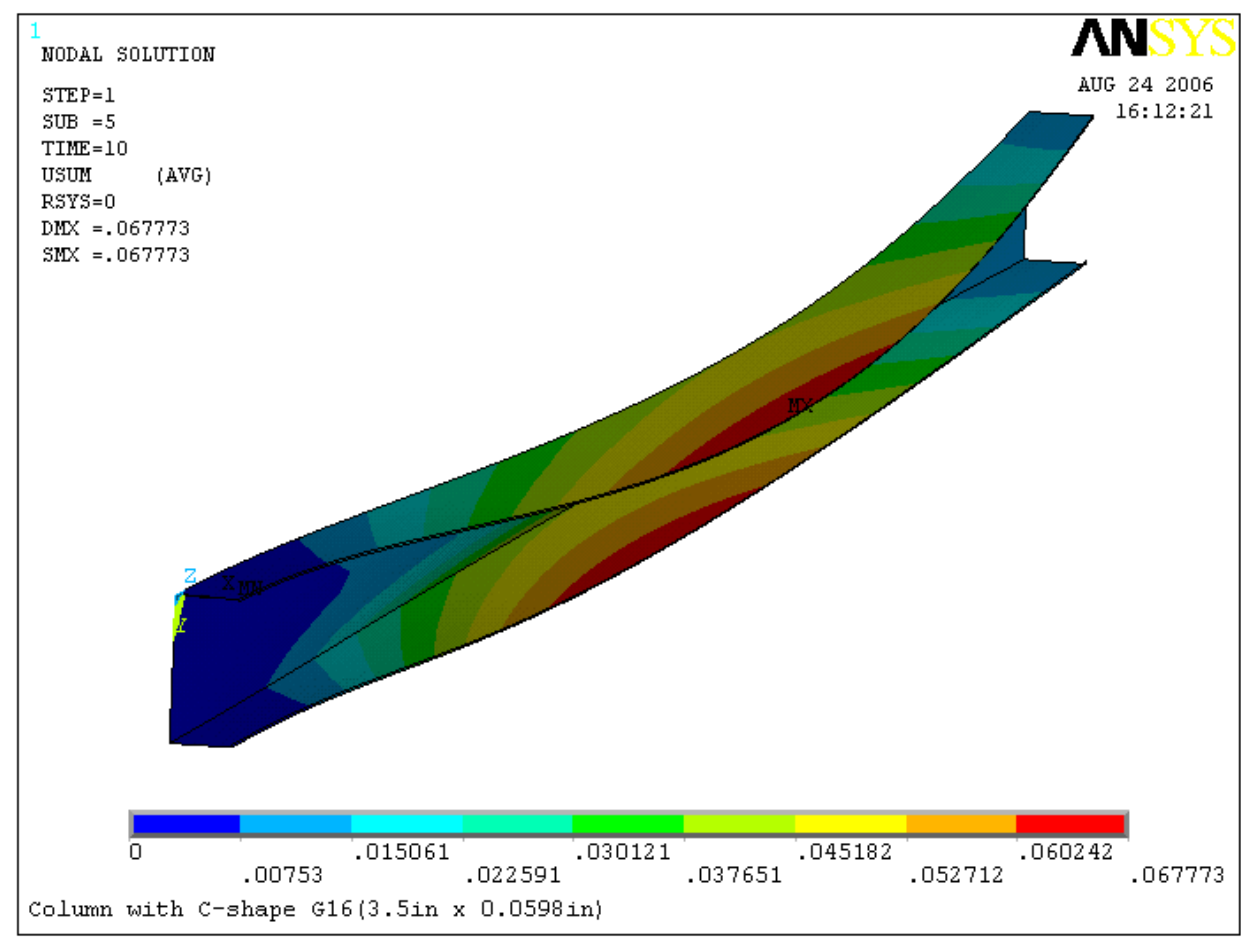

Figure 4.6 Deformation of C2×4 C-shape profile with 16 Gage (unit: inches) 


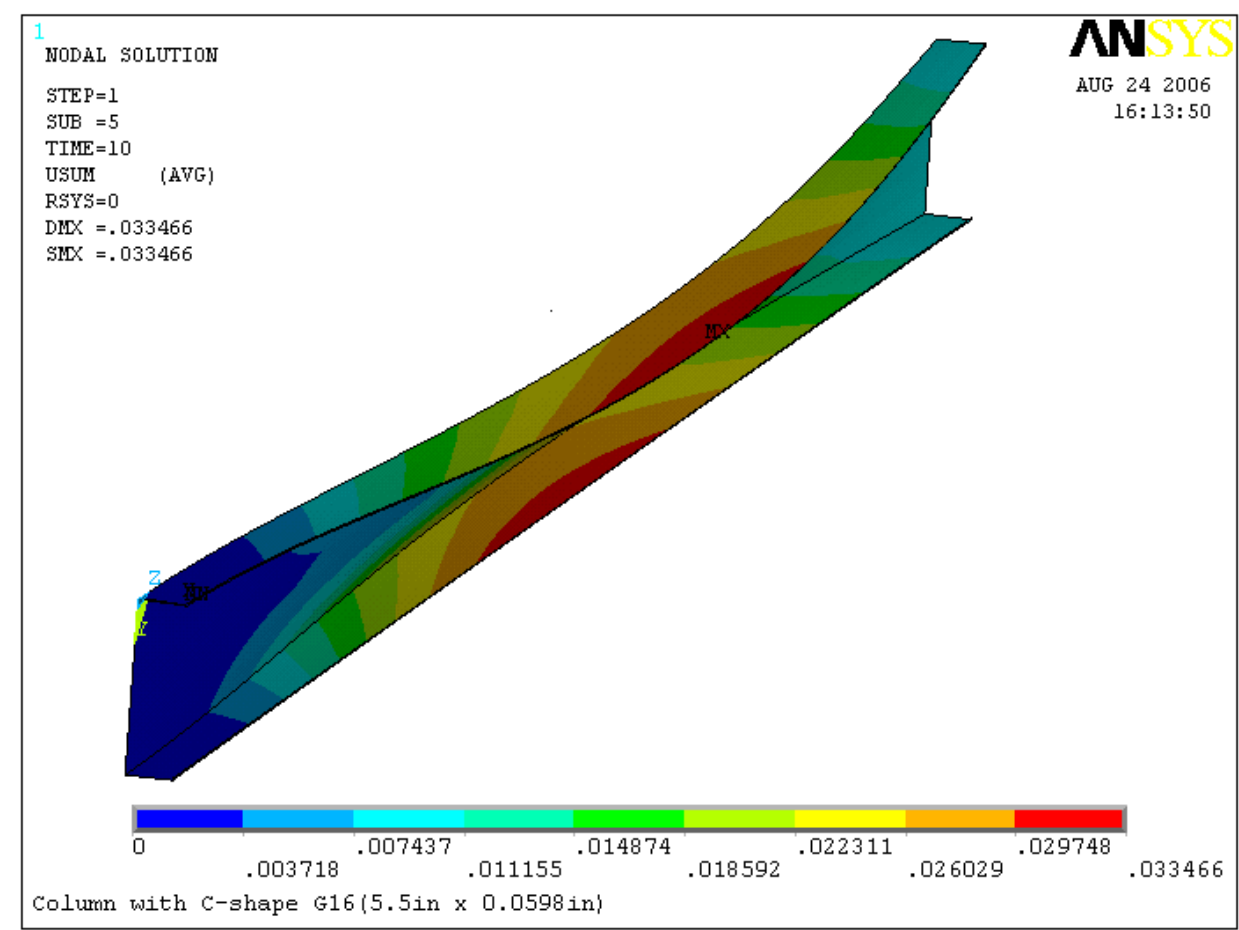

Figure 4.7 Deformation of C2×6 C-shape profile with 16 Gage (unit: inches)

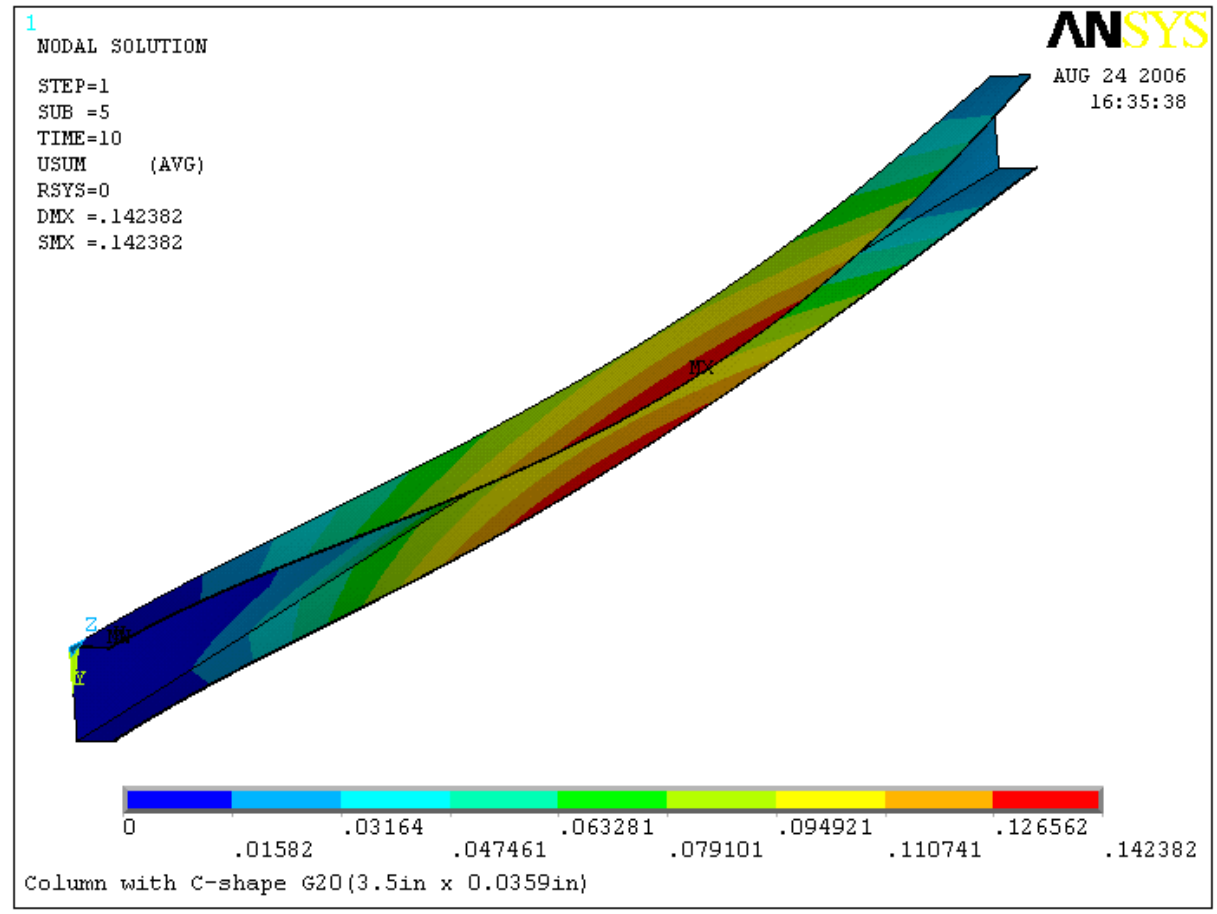

Figure 4.8 Deformation of C2×4 C-shape profile with 20 Gage (unit: inches) 


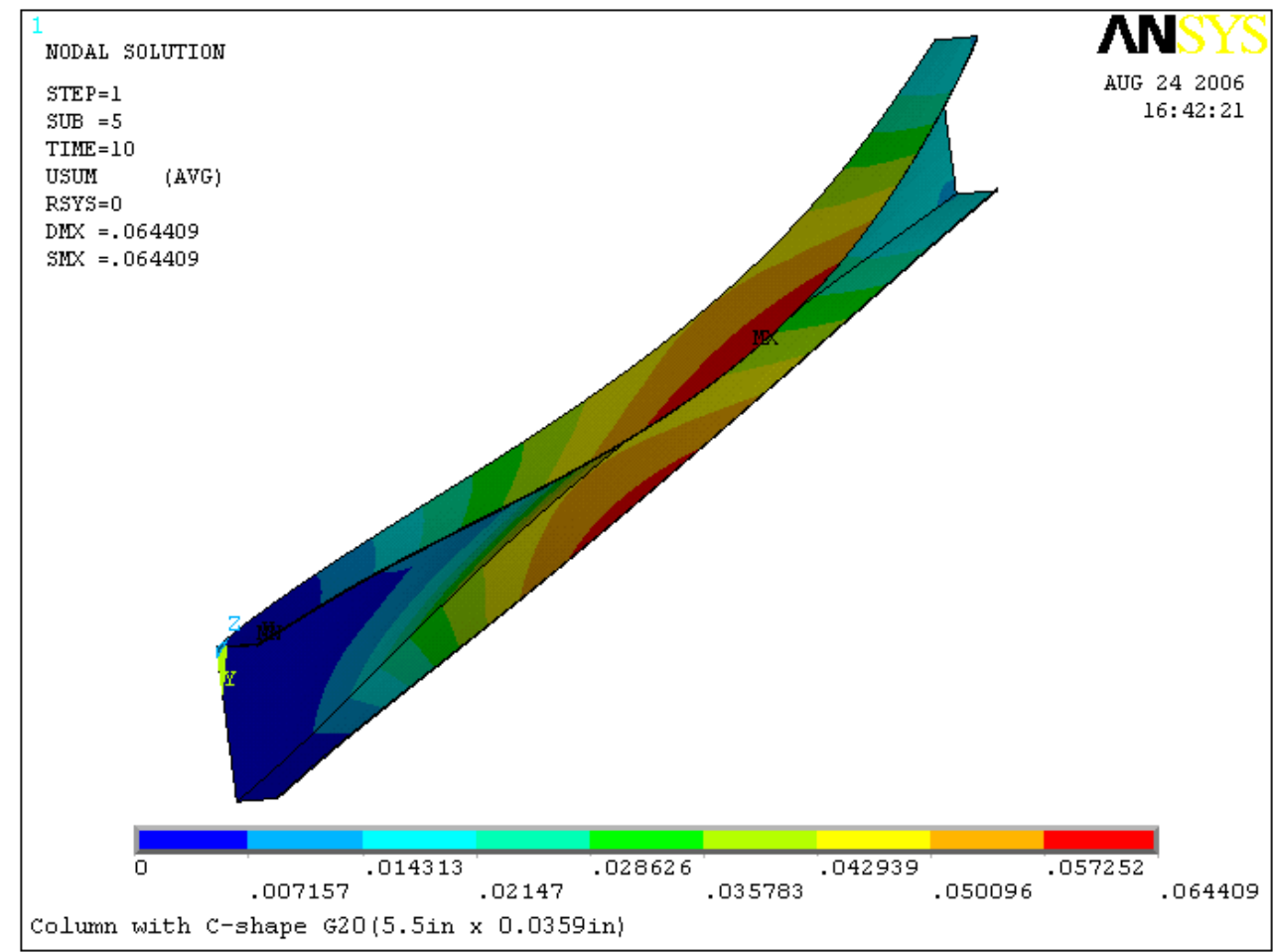

Figure 4.9 Deformation of C2×6 C-shape profile with 20 Gage (unit: inches) 
4.2.1.2 Rotation of C-shape column under the load Case 1

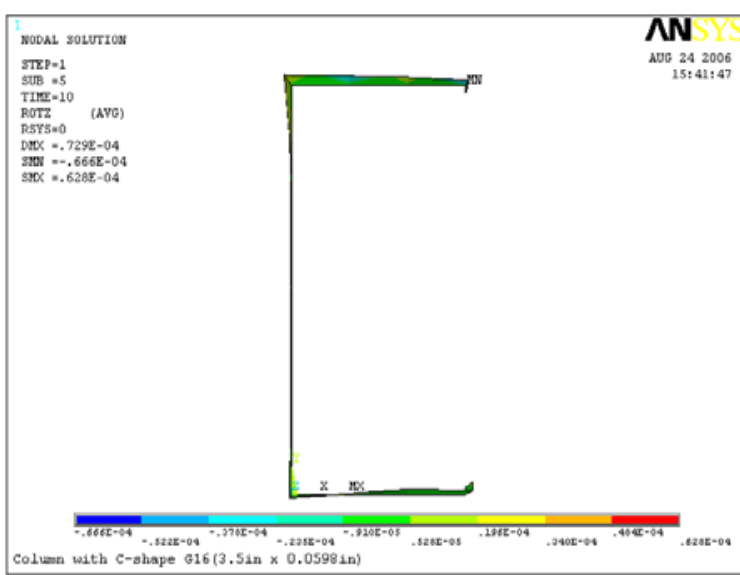

(a) Cross-section view ( $\mathrm{Z}=0.0 \mathrm{in}$.)

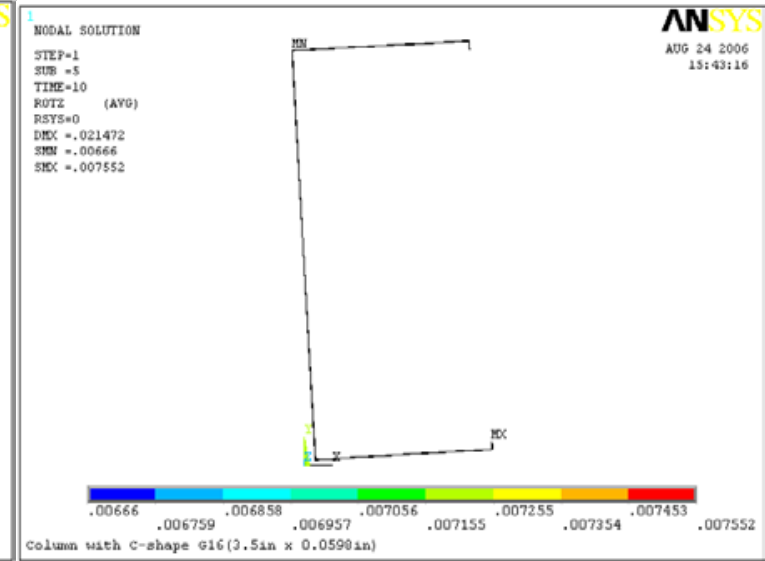

(b) Cross-section view ( $\mathrm{Z}=20.0 \mathrm{in}$.)

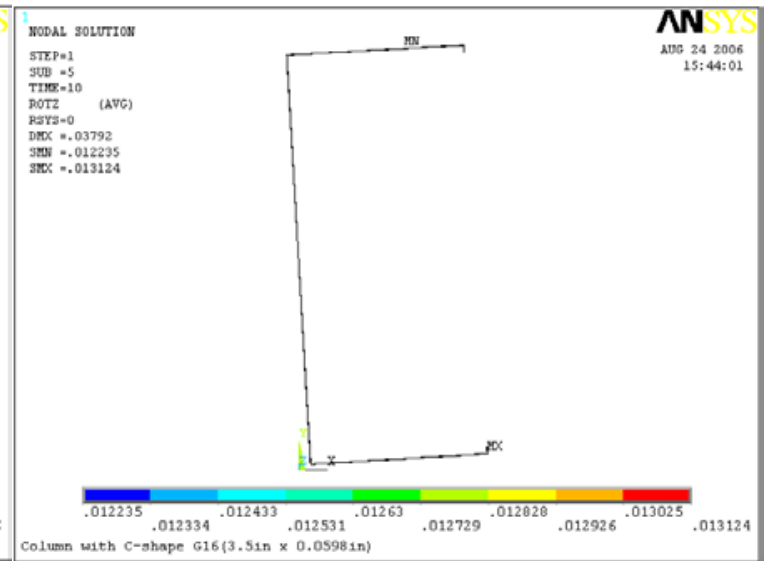

(c) Cross-section view ( $\mathrm{Z}=30.0$ in.)
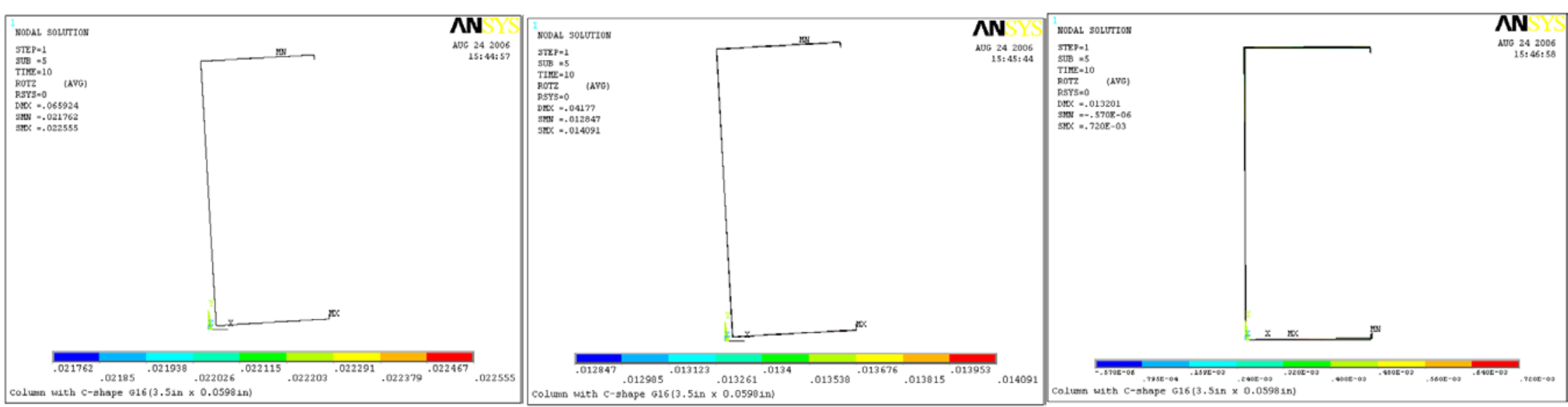

(d) Cross-section view ( $\mathrm{Z}=54.0$ in.)

(e) Cross-section view ( $\mathrm{Z}=90.0$ in.)

(f) Cross-section view ( $\mathrm{Z}=108.0$ in.)

Figure 4.10 Cross-section view of C-shape 16 Gage (C2×4) 

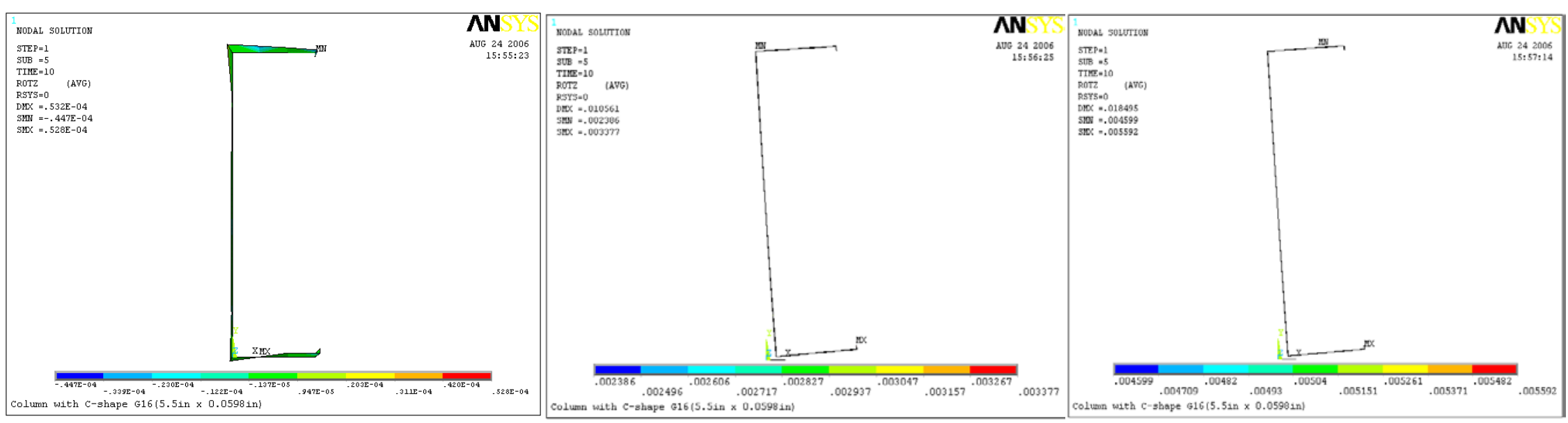

(a) Cross-section view ( $\mathrm{Z}=0.0$ in.)

(b) Cross-section view ( $\mathrm{Z}=20.0$ in.)

(c) Cross-section view ( $\mathrm{Z}=30.0$ in.)

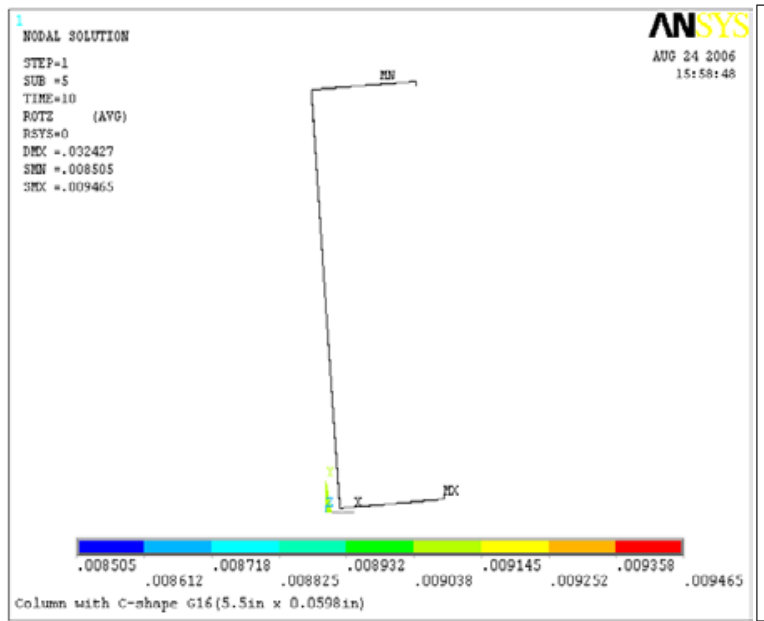

(d) Cross-section view ( $\mathrm{Z}=54.0$ in.)

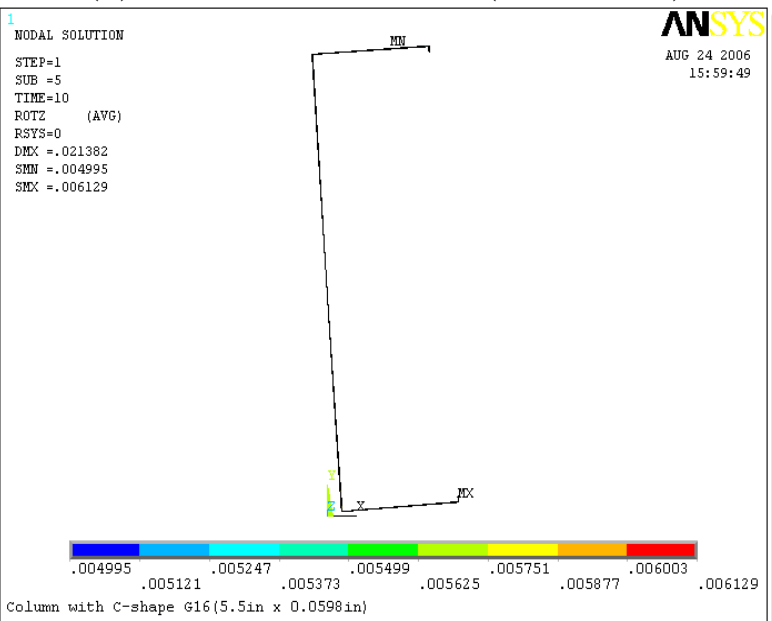

(e) Cross-section view ( $\mathrm{Z}=90.0$ in.)

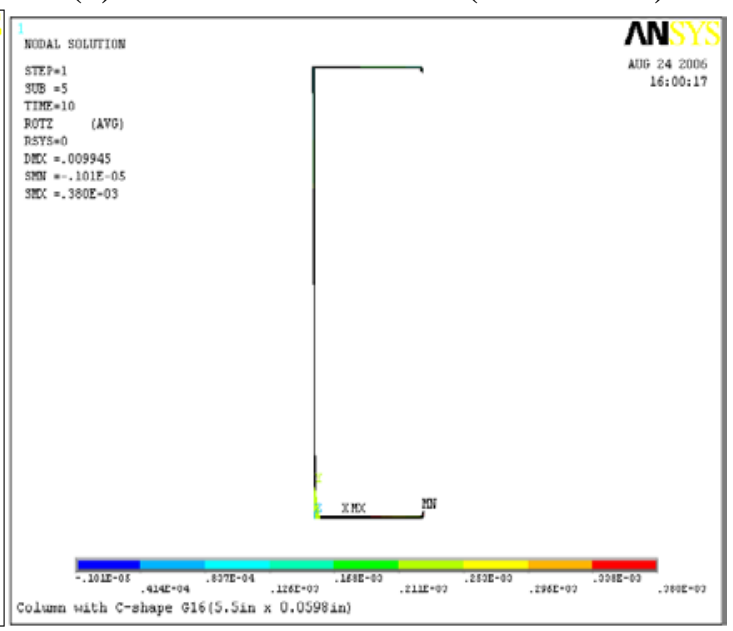

(f) Cross-section view ( $\mathrm{Z}=108.0$ in)

Figure 4.11 Cross-section view of C- shape 16 Gage (C2×6) 


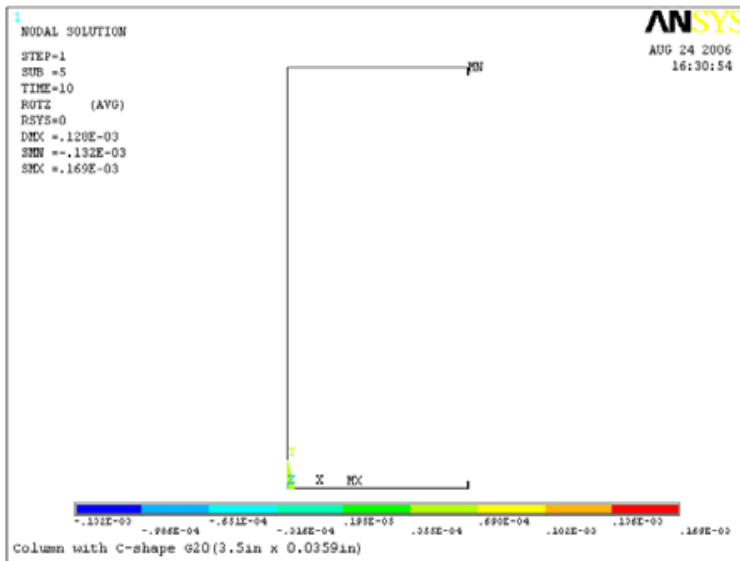

(a) Cross-section view ( $\mathrm{Z}=0.0$ in.)

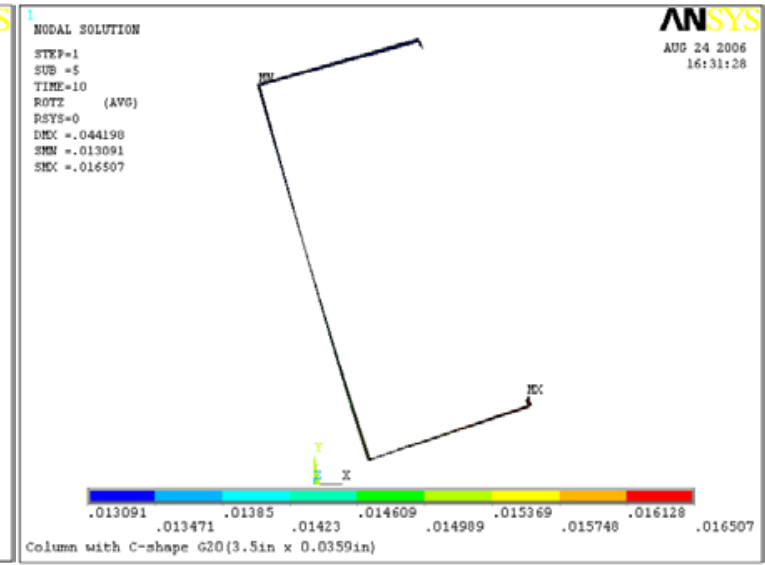

(b) Cross-section view ( $\mathrm{Z}=20.0$ in.)

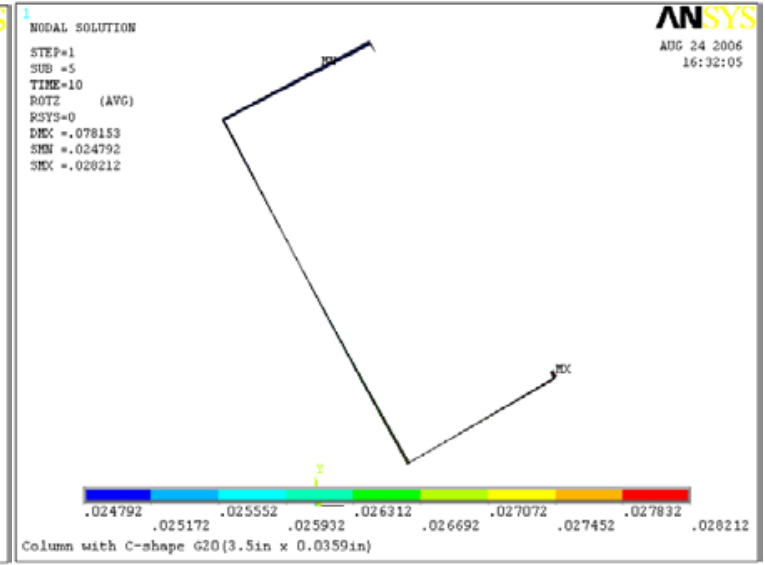

(c) Cross-section view ( $\mathrm{Z}=30.0$ in.)

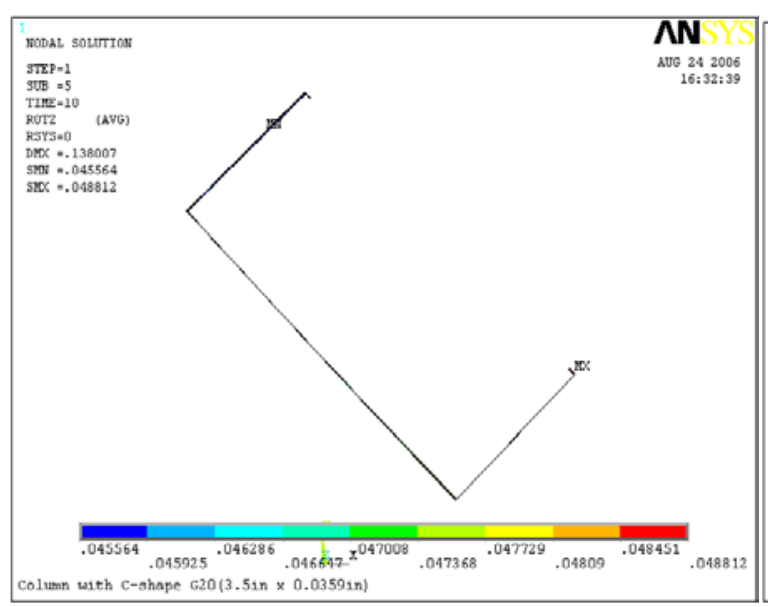

(d) Cross-section view ( $\mathrm{Z}=54.0$ in.)

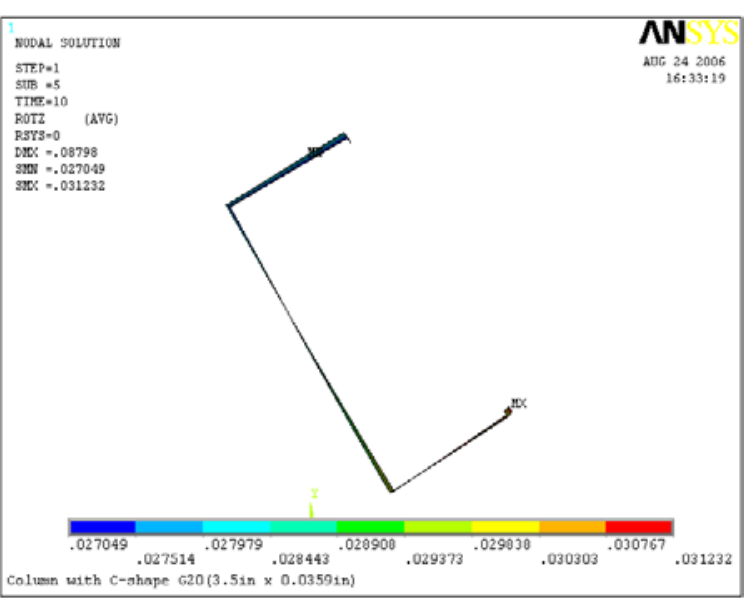

(e) Cross-section view ( $\mathrm{Z}=90.0$ in.)

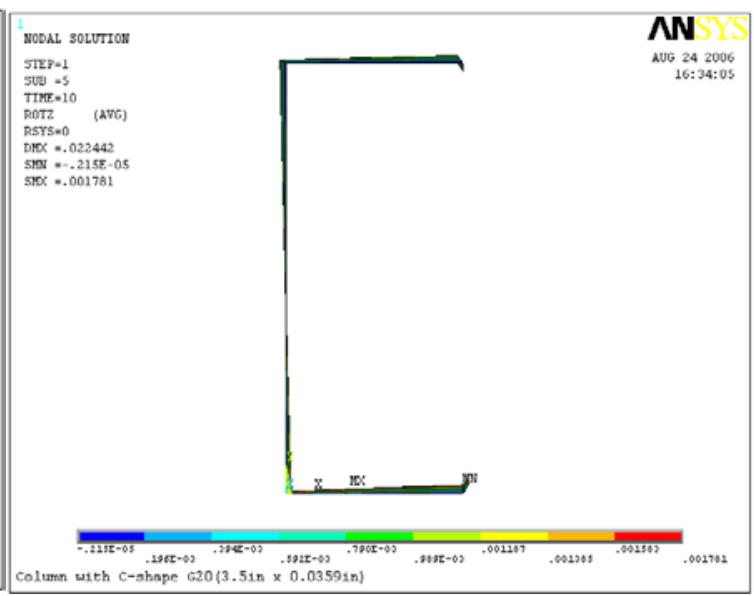

(f) Cross-section view ( $\mathrm{Z}=108.0 \mathrm{in})$

Figure 4.12 Cross-section view of C-shape 20 Gage (C2×4) 


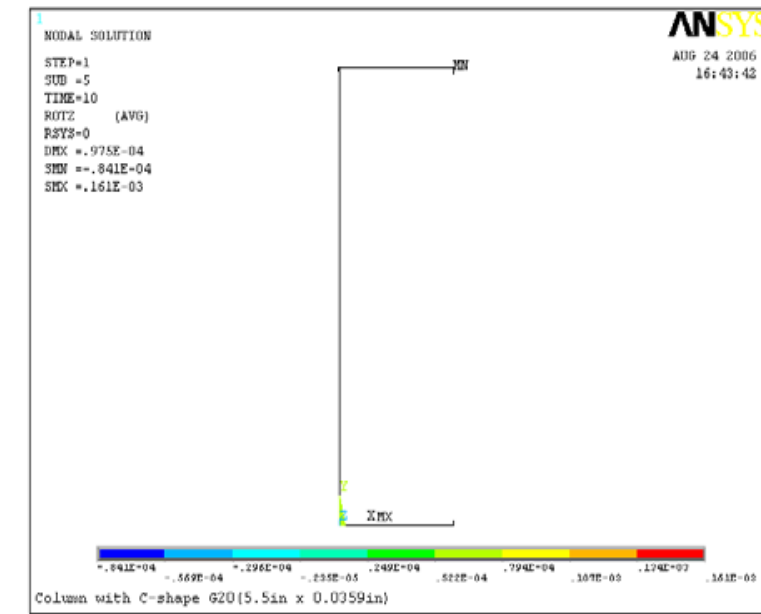

(a) Cross-section view ( $\mathrm{Z}=0.0 \mathrm{in}$.)

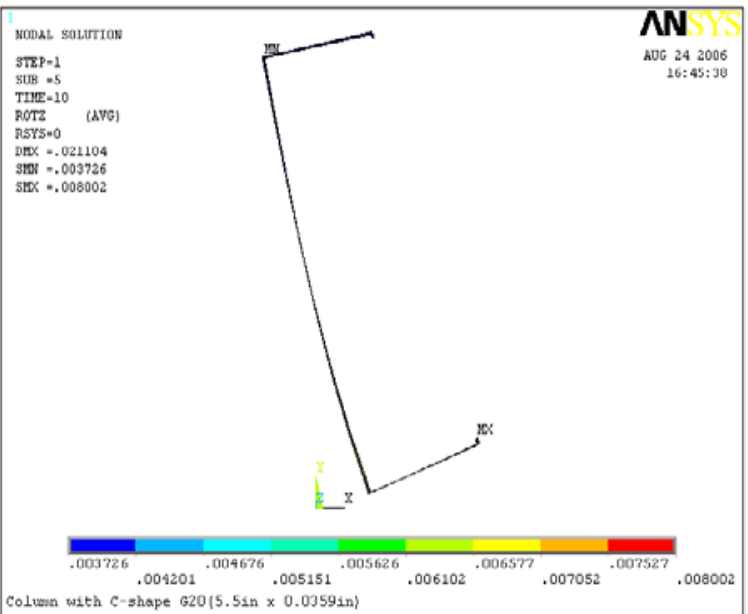

(b) Cross-section view ( $\mathrm{Z}=20.0$ in.)

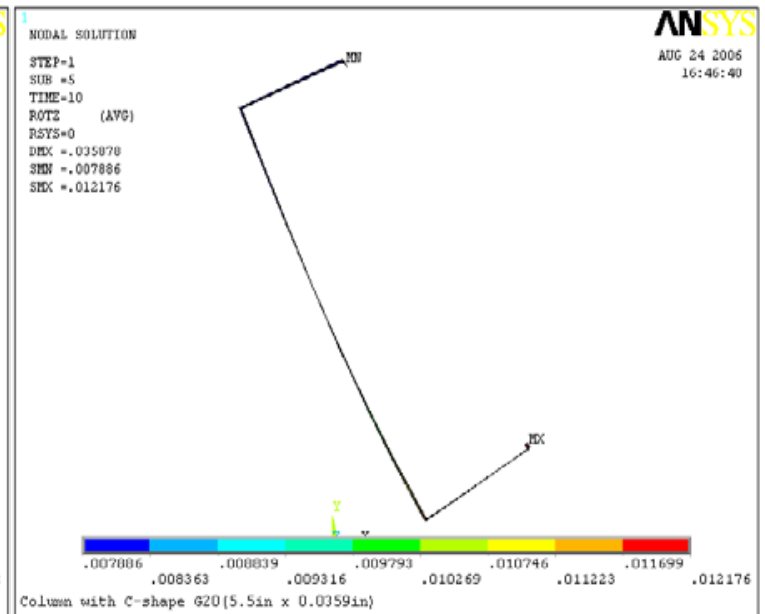

(c) Cross-section view ( $\mathrm{Z}=30.0$ in.)

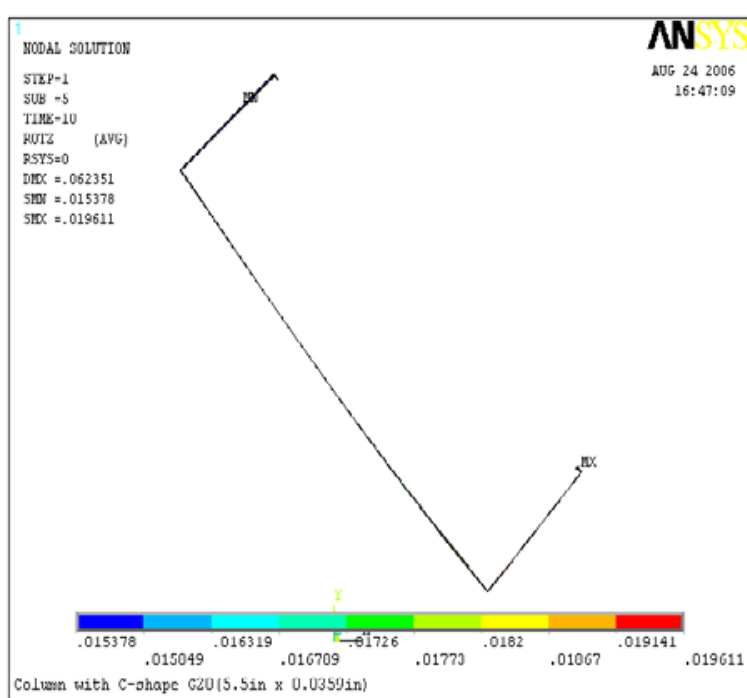

(d) Cross-section view ( $\mathrm{Z}=54.0$ in.)

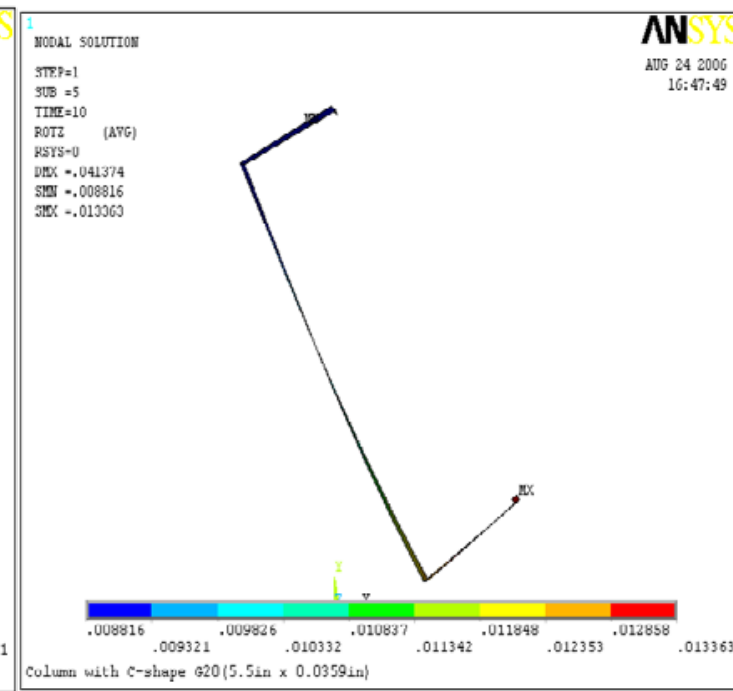

(e) Cross-section view ( $\mathrm{Z}=90.0$ in.)

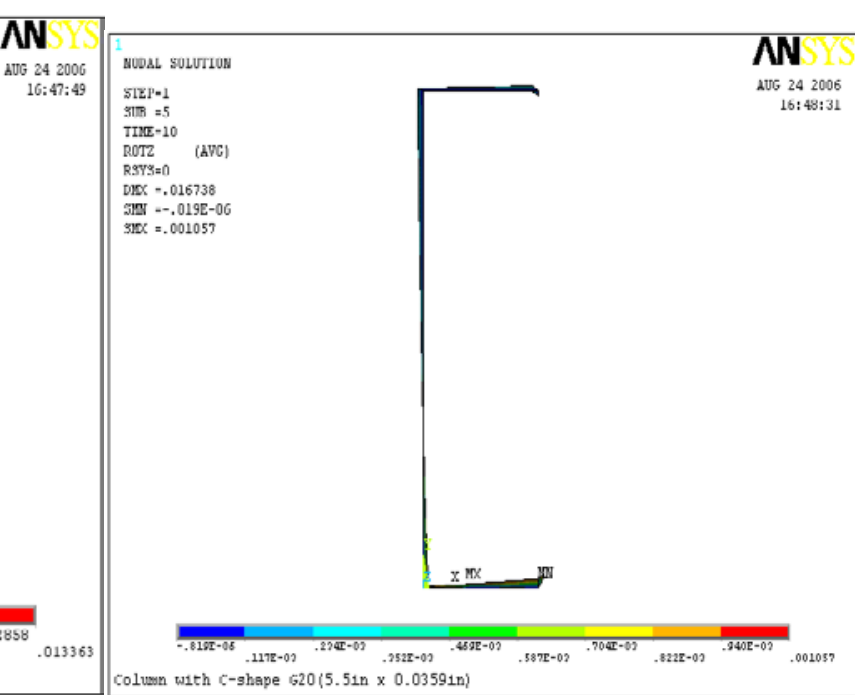

(f) Cross-section view ( $\mathrm{Z}=108.0 \mathrm{in})$

Figure 4.13 Cross-section view of C- shape 20 Gage (C2×6) 


\subsubsection{Deformation of C-shape column under the load Case 2}

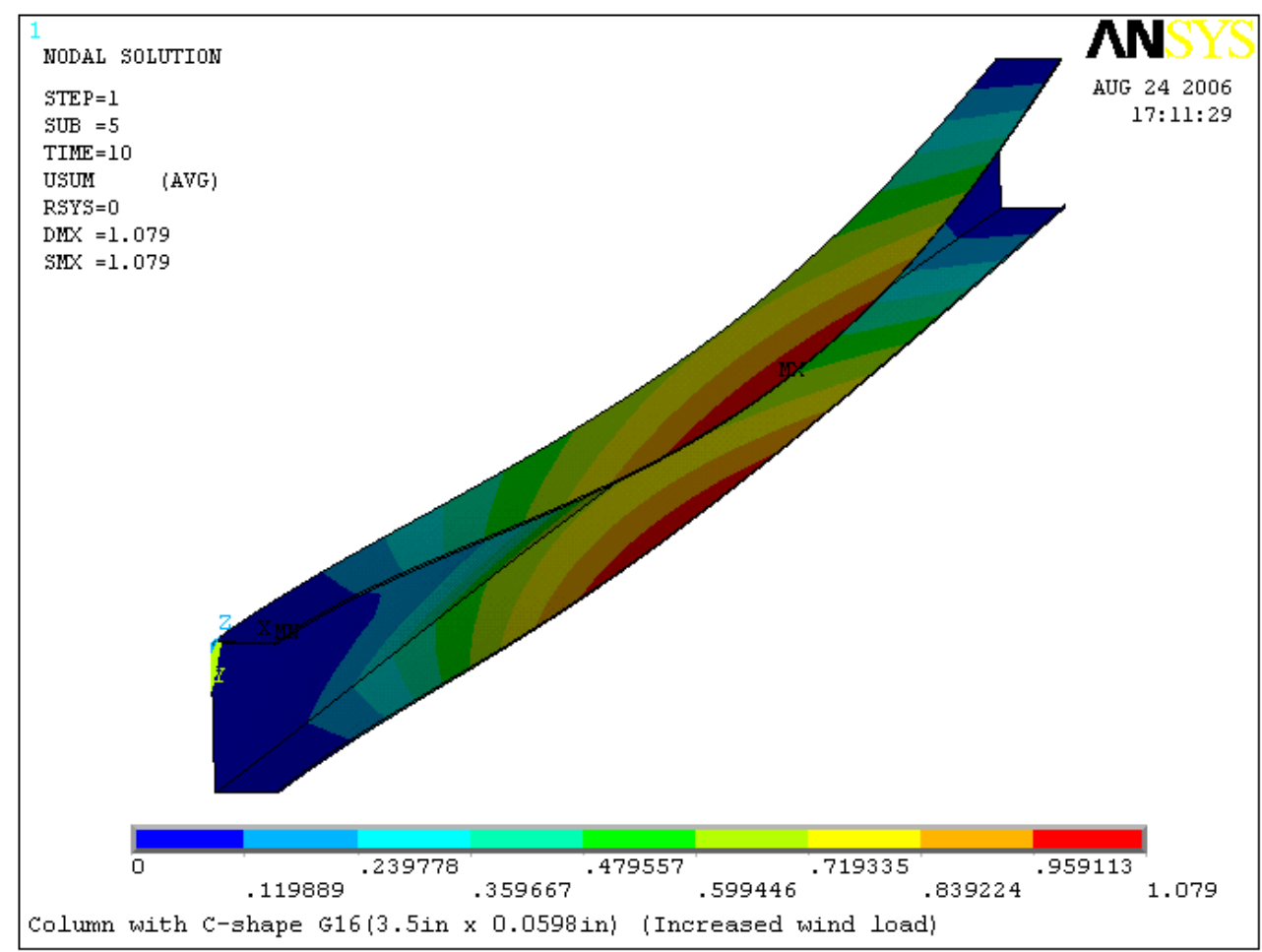

Figure 4.14 Deformation of C2×4 C-shape profile with 16 Gage (unit: inches)

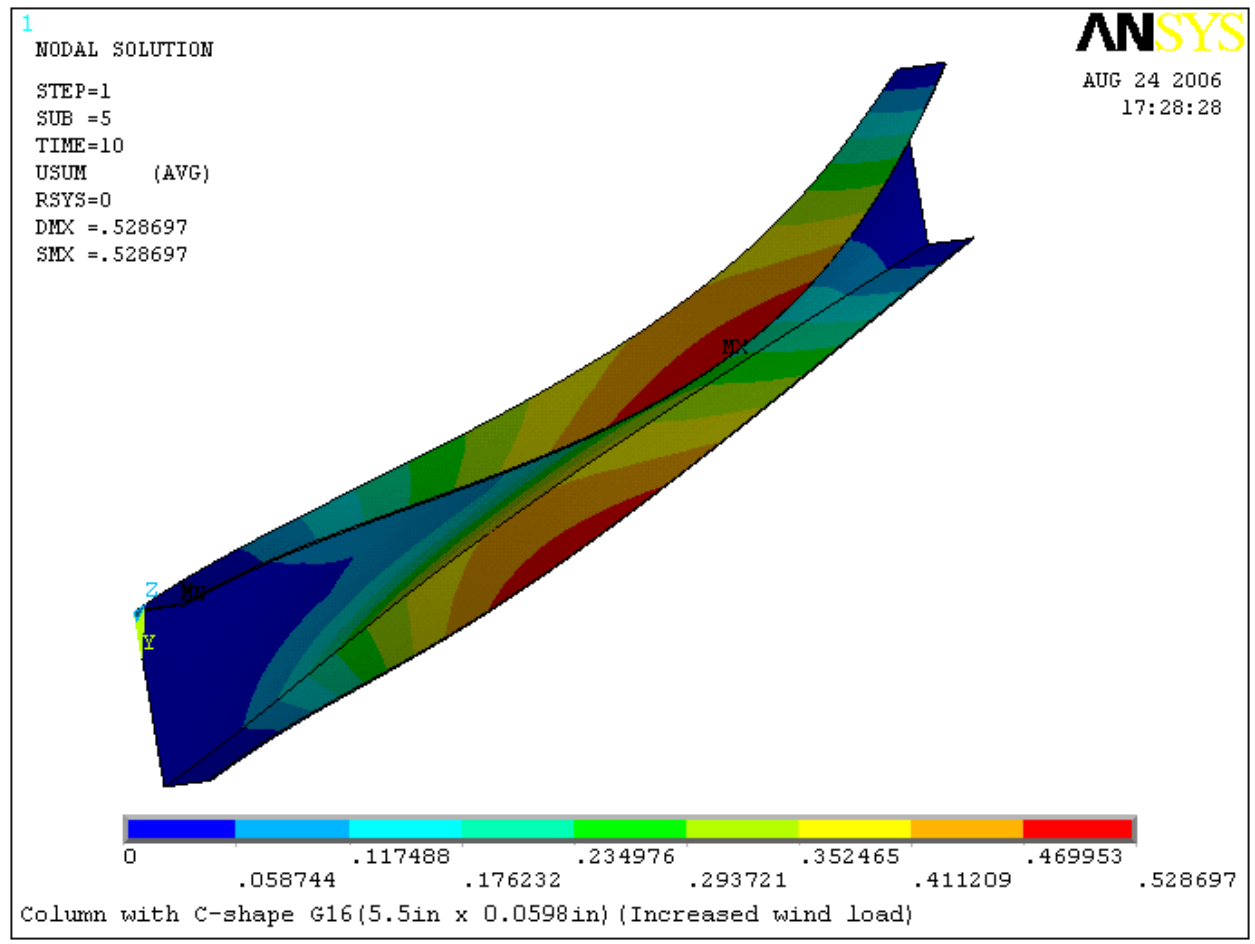

Figure 4.15 Deformation of C 2×6 C-shape profile with 16 Gage (unit: inches) 
4.2.1.4 Rotation of C-shape column under the load Case 2

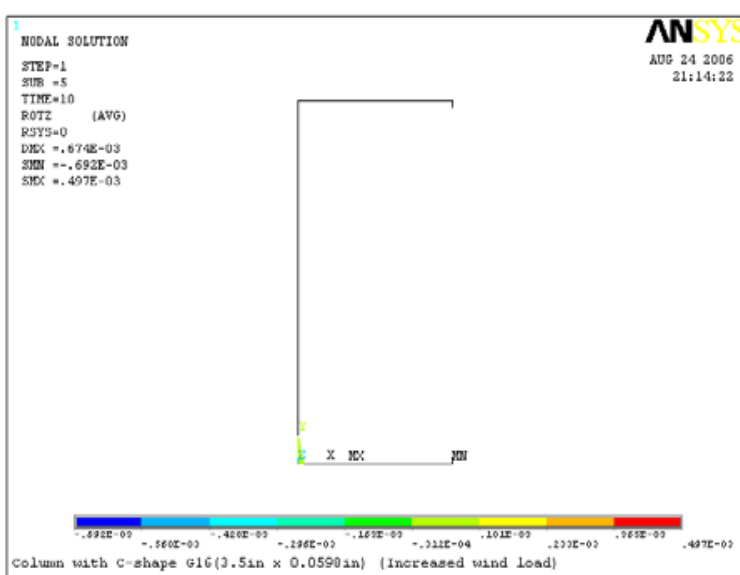

(a) Cross-section view ( $\mathrm{Z}=0.0$ in.)

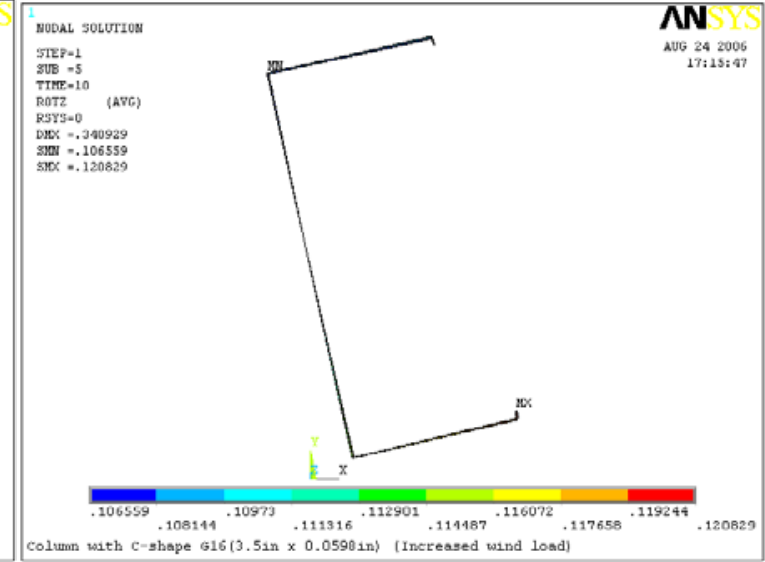

(b) Cross-section view ( $\mathrm{Z}=20.0$ in.)

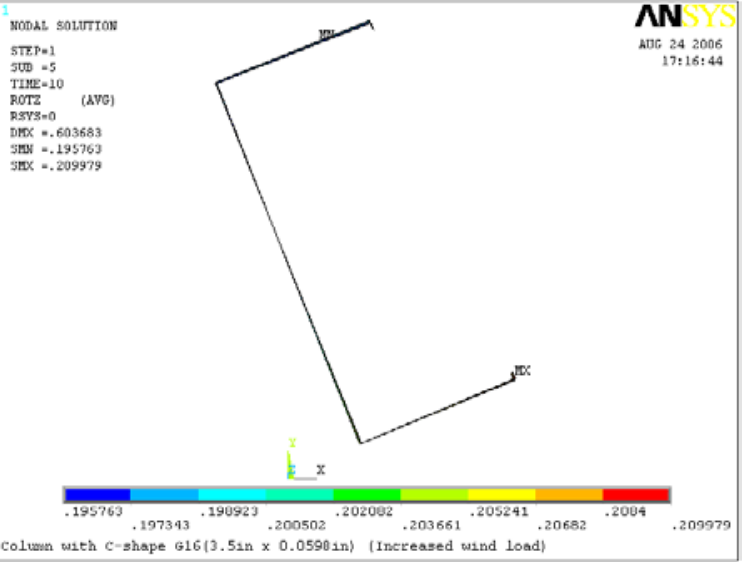

(c) Cross-section view ( $\mathrm{Z}=30.0$ in.)

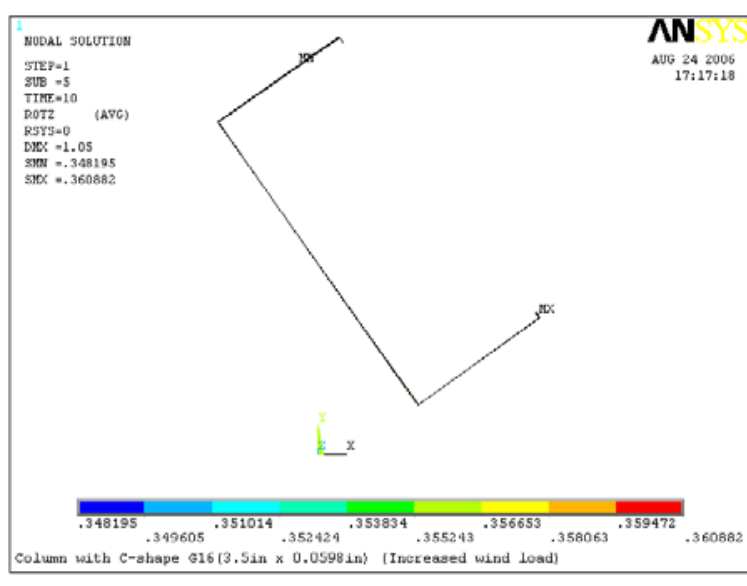

(d) Cross-section view ( $\mathrm{Z}=54.0$ in.)

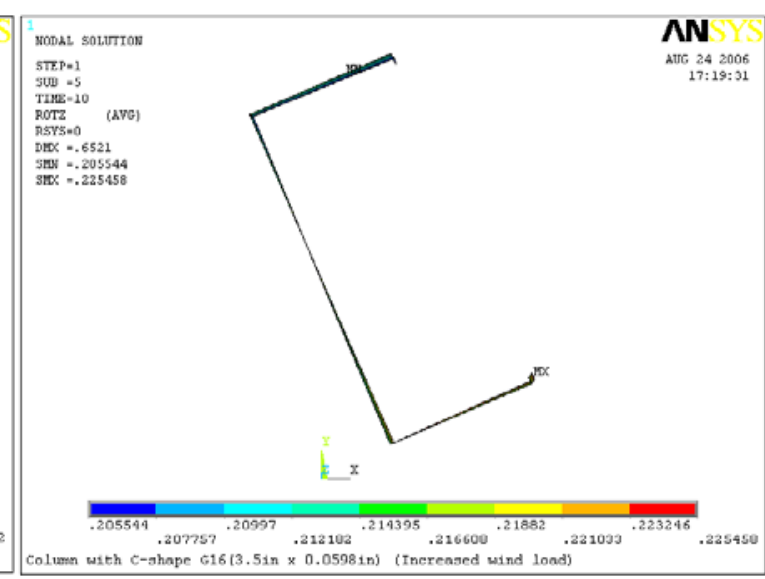

(e) Cross-section view ( $\mathrm{Z}=90.0$ in.)

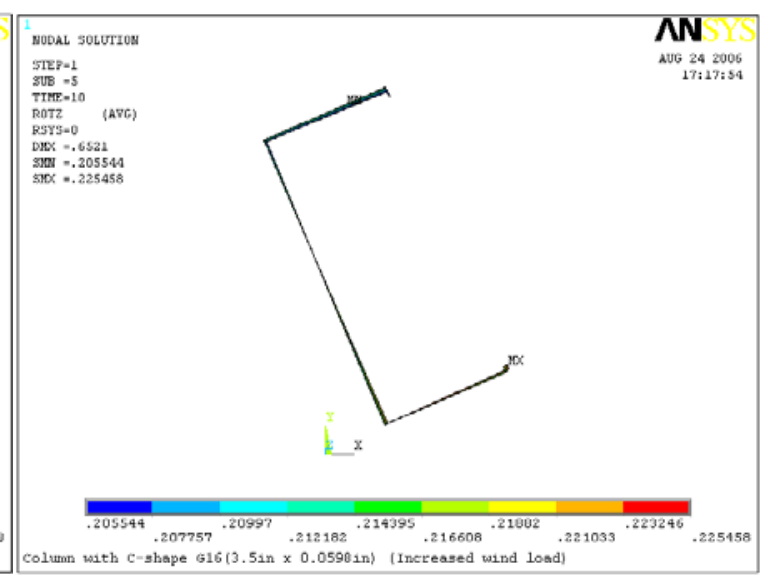

(f) Cross-section view ( $\mathrm{Z}=108.0 \mathrm{in})$

Figure 4.16 Cross-section view of C-shape 16 Gage (C2×4) 


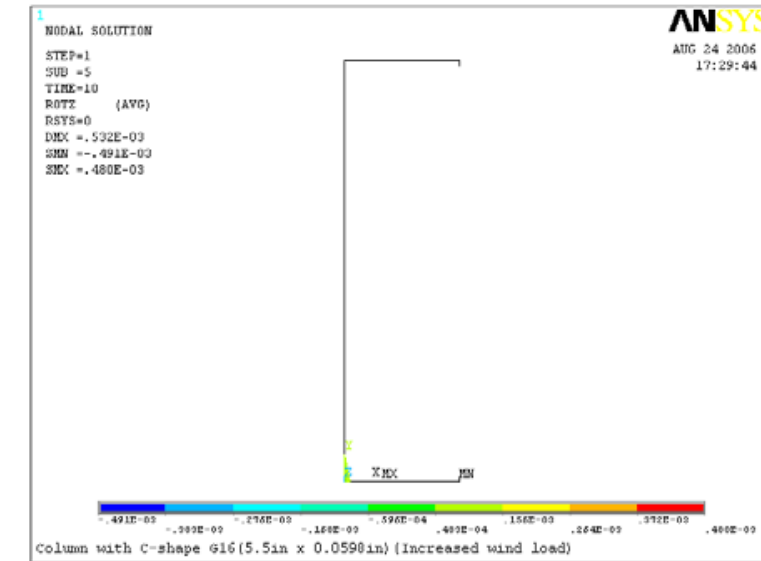

(a) Cross-section view ( $\mathrm{Z}=0.0$ in.)

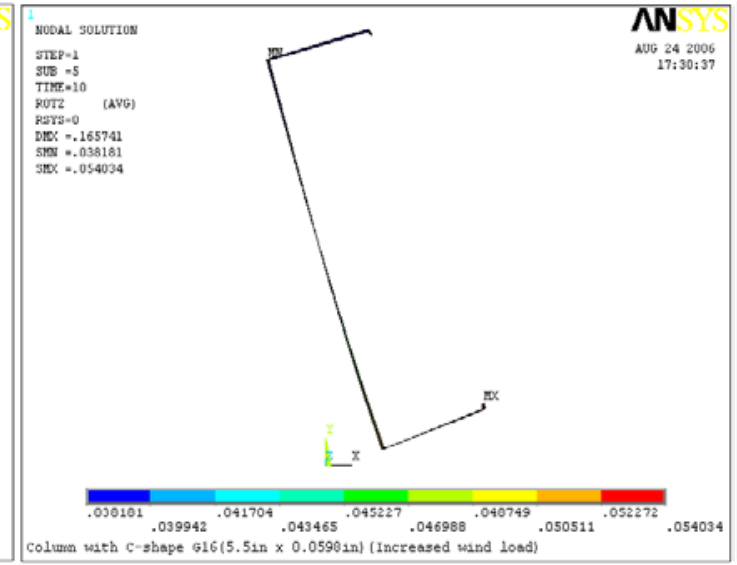

(b) Cross-section view ( $\mathrm{Z}=20.0$ in.)

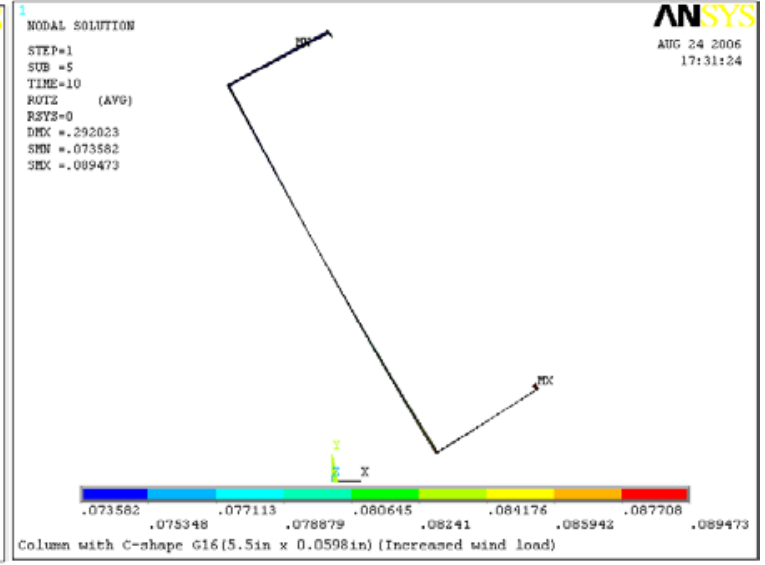

(c) Cross-section view ( $\mathrm{Z}=30.0$ in.)
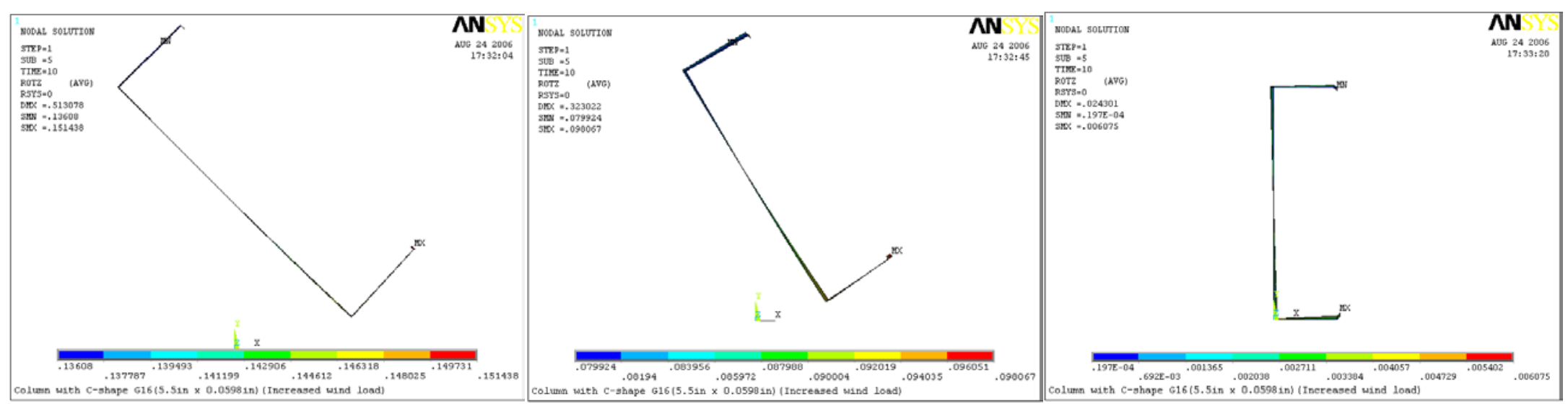

(d) Cross-section view ( $\mathrm{Z}=54.0$ in.)

(e) Cross-section view ( $\mathrm{Z}=90.0$ in.)

(f) Cross-section view ( $\mathrm{Z}=108.0 \mathrm{in})$

Figure 4.17 Cross-section view of C- shape 16 Gage (C2×6) 
It was observed that the maximum deformation of the C-shape profiles increased as the thickness of the steel decreased. For example, the maximum deformation of the $2 \times 4 \mathrm{C}$-shape profile increased from 0.0678 in to 0.142 in when steel thickness changed from 16 gage to 20 gage. For the same steel thickness, the maximum deformation of the C-shape profiles decreased as the height of the channel-web increased. For example, the maximum deformation of the C-shape profile with 16 gage thickness varied from 0.0678 in. to 0.033 in. when the height of the web increased from $3.5 \mathrm{in}$. to $5.5 \mathrm{in}$.

The maximum rotations of the C-shape profiles follow the same trend as the maximum deformation: increased as the thickness of the steel decreased and decreased as height of the web increased. For example, the maximum rotation of the 2×6 C-shape profile varied from 0.0097 rad to 0.0202 rad when the steel thickness changed from 16 gage to 20 gage; For the same thickness of the steel, the maximum rotation of the C-shape profile made of 20 gage steel decreased from 0.0503 rad to 0.0202 rad when the height of the web increased from $3.5 \mathrm{in}$. to $5.5 \mathrm{in}$.

\subsubsection{Stresses of the C-shape profiles}

Figures 4.18 through 4.25 show the stresses in longitudinal direction of the C-shape profiles made of 16 Gage and 20 Gage steel under the load Case 1. Figures 4.26 through 4.29 show the stresses in longitudinal direction of C-shape profile made of 16 Gage steel under the load Case 2. The figures present the stresses in the front side and back side of each profile with deformed shape. 
4.2.2.1 Stresses in longitudinal direction of C-shape profile under the load Case 1

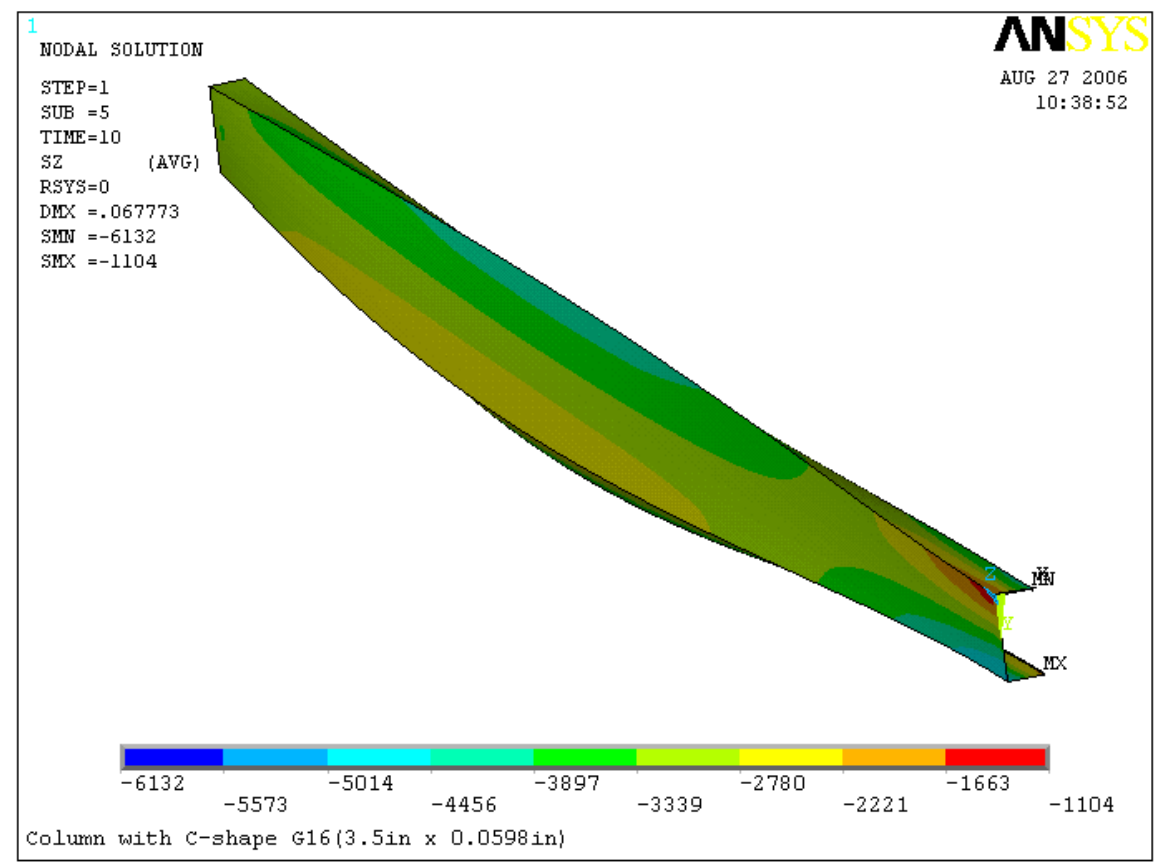

Figure 4.18 Stresses in the back side of $\mathrm{C} 2 \times 4$ profile with 16 Gage (units: psi)

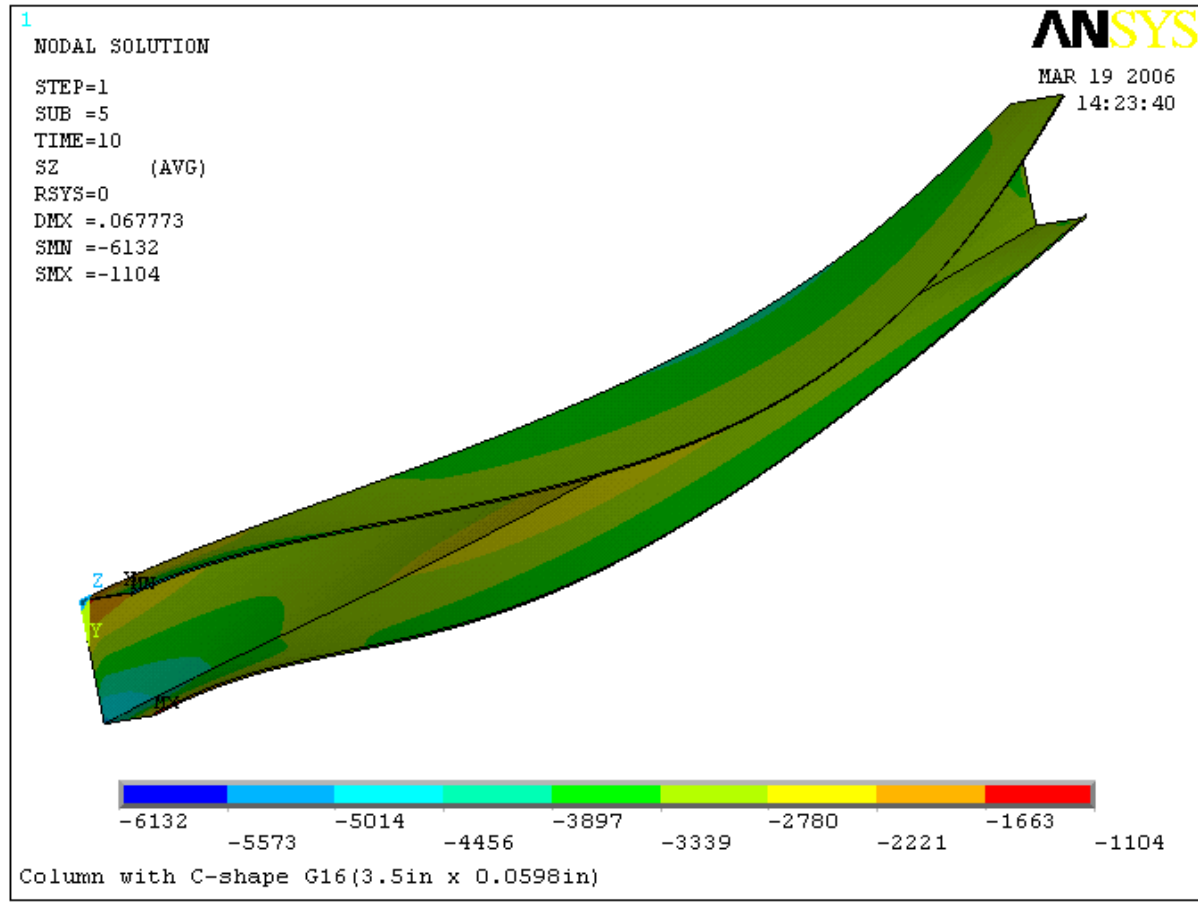

Figure 4.19 Stresses in the front side of $\mathrm{C} 2 \times 4$ profile with 16 Gage (units: psi) 


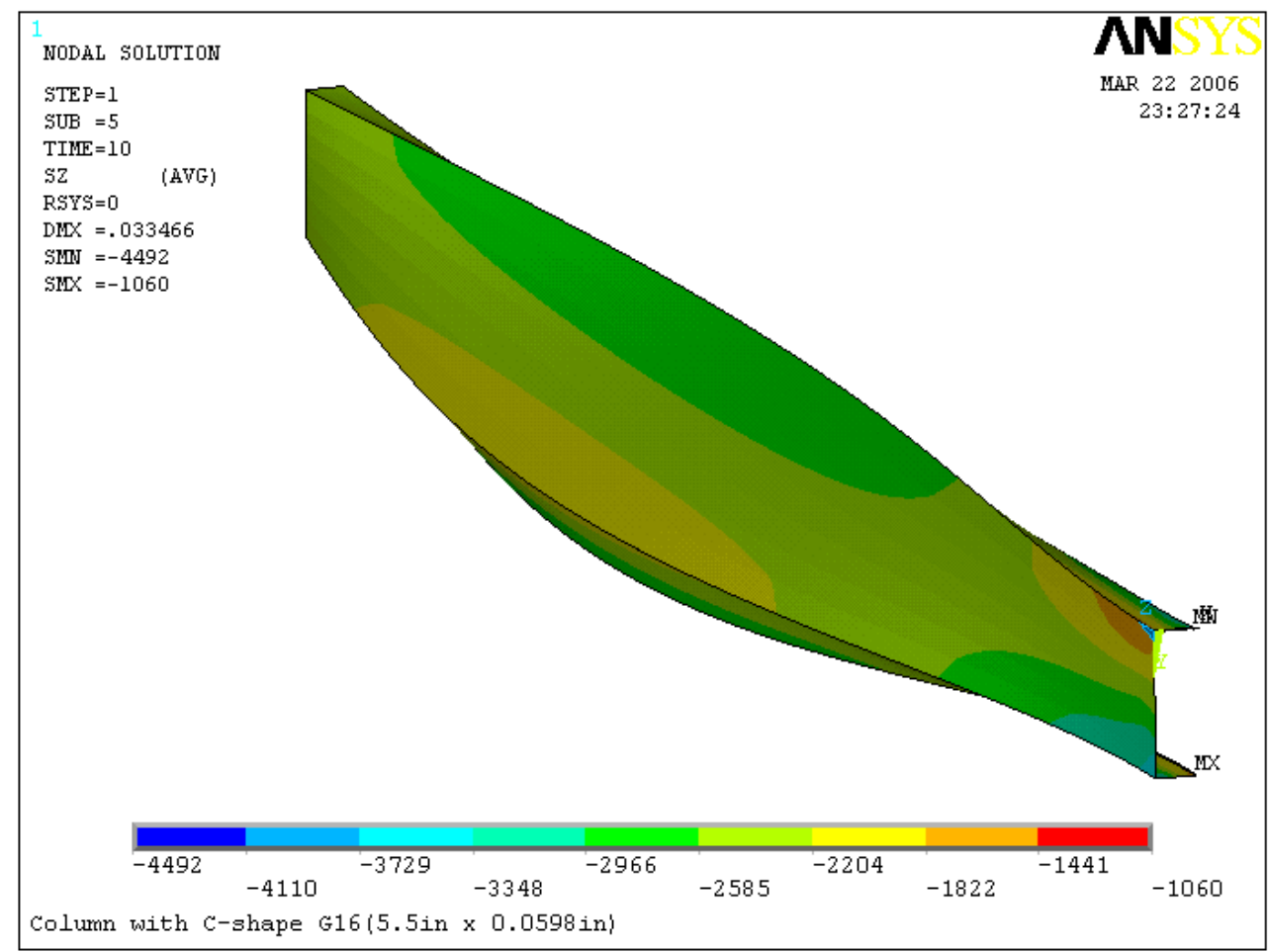

Figure 4.20 Stresses in the back side of $\mathrm{C} 2 \times 6$ profile with 16 Gage (units: psi)

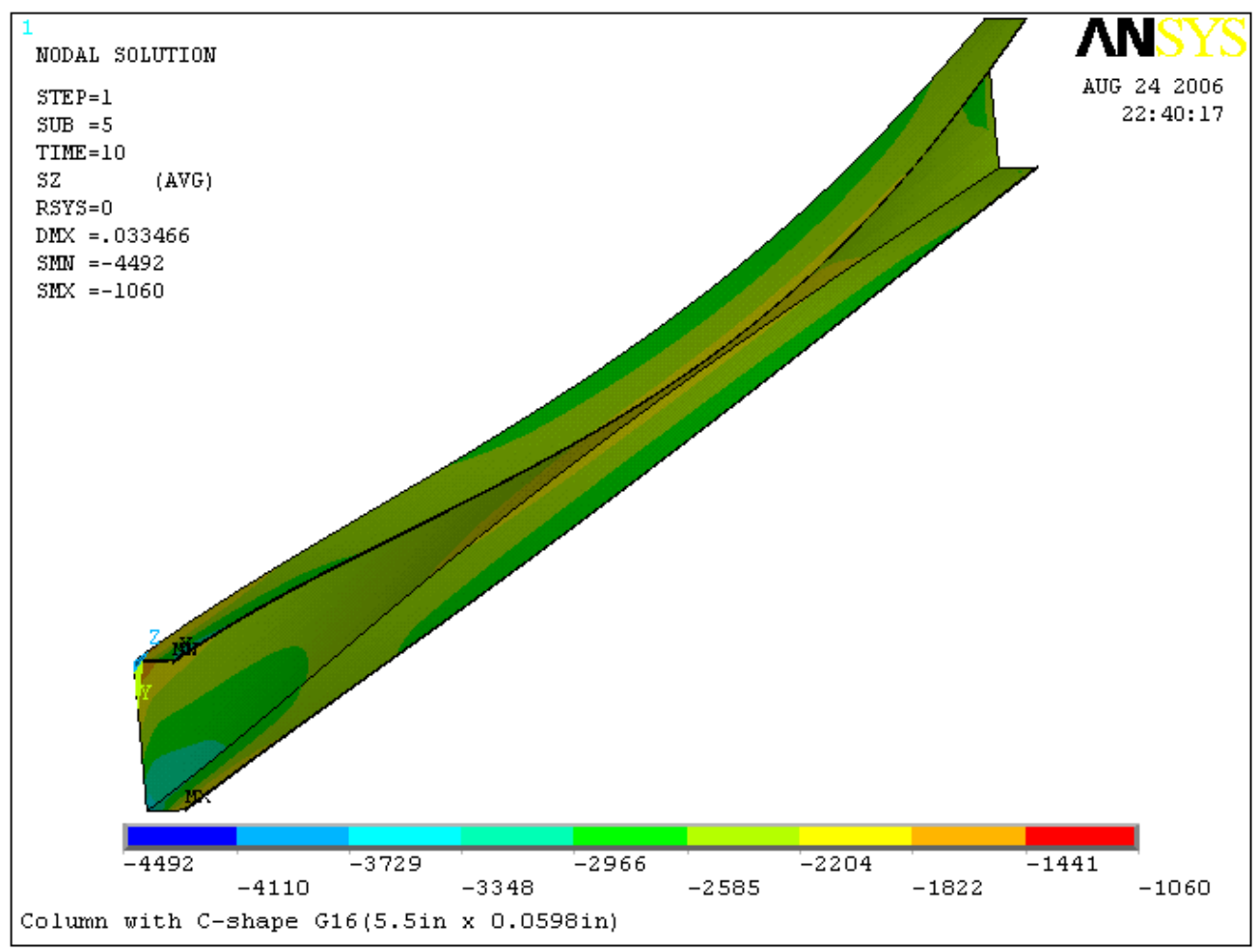

Figure 4.21 Stresses in the front side of $\mathrm{C} 2 \times 6$ profile with 16 Gage (units: psi) 


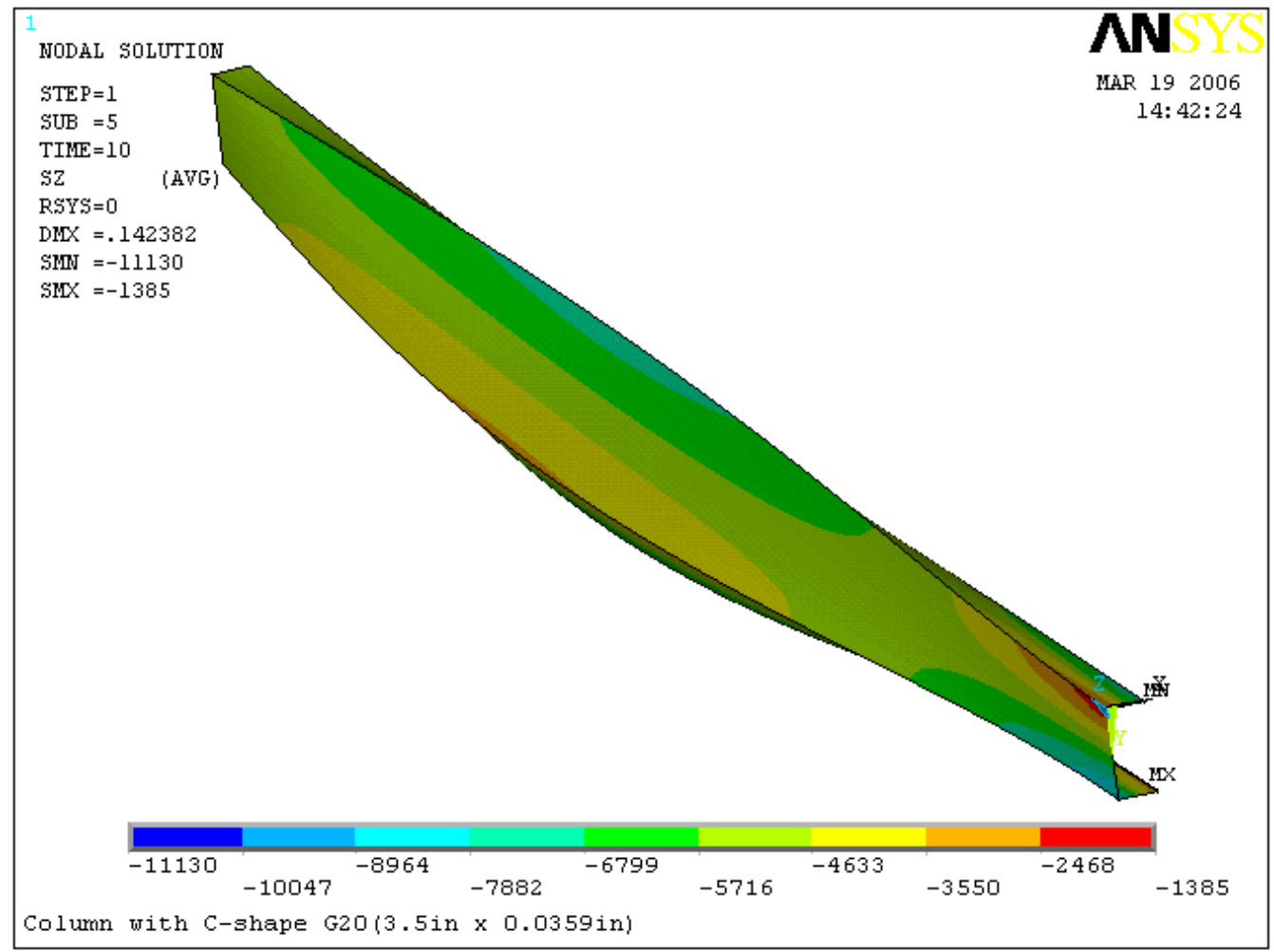

Figure 4.22 Stresses in the back side of $\mathrm{C} 2 \times 4$ profile with 20 Gage (units: psi)

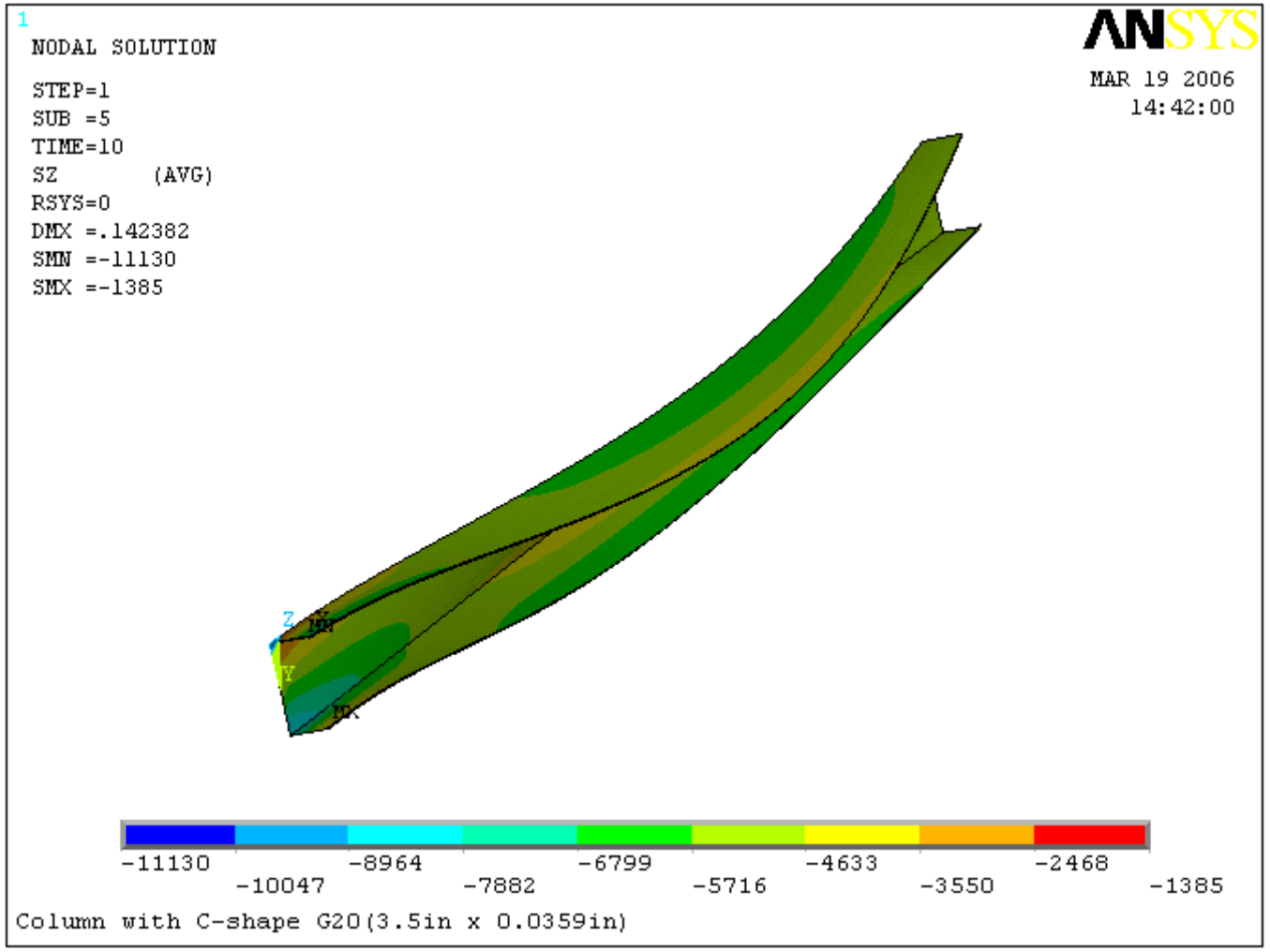

Figure 4.23 Stresses in the front side of C2×4 profile with 20 Gage (units: psi) 


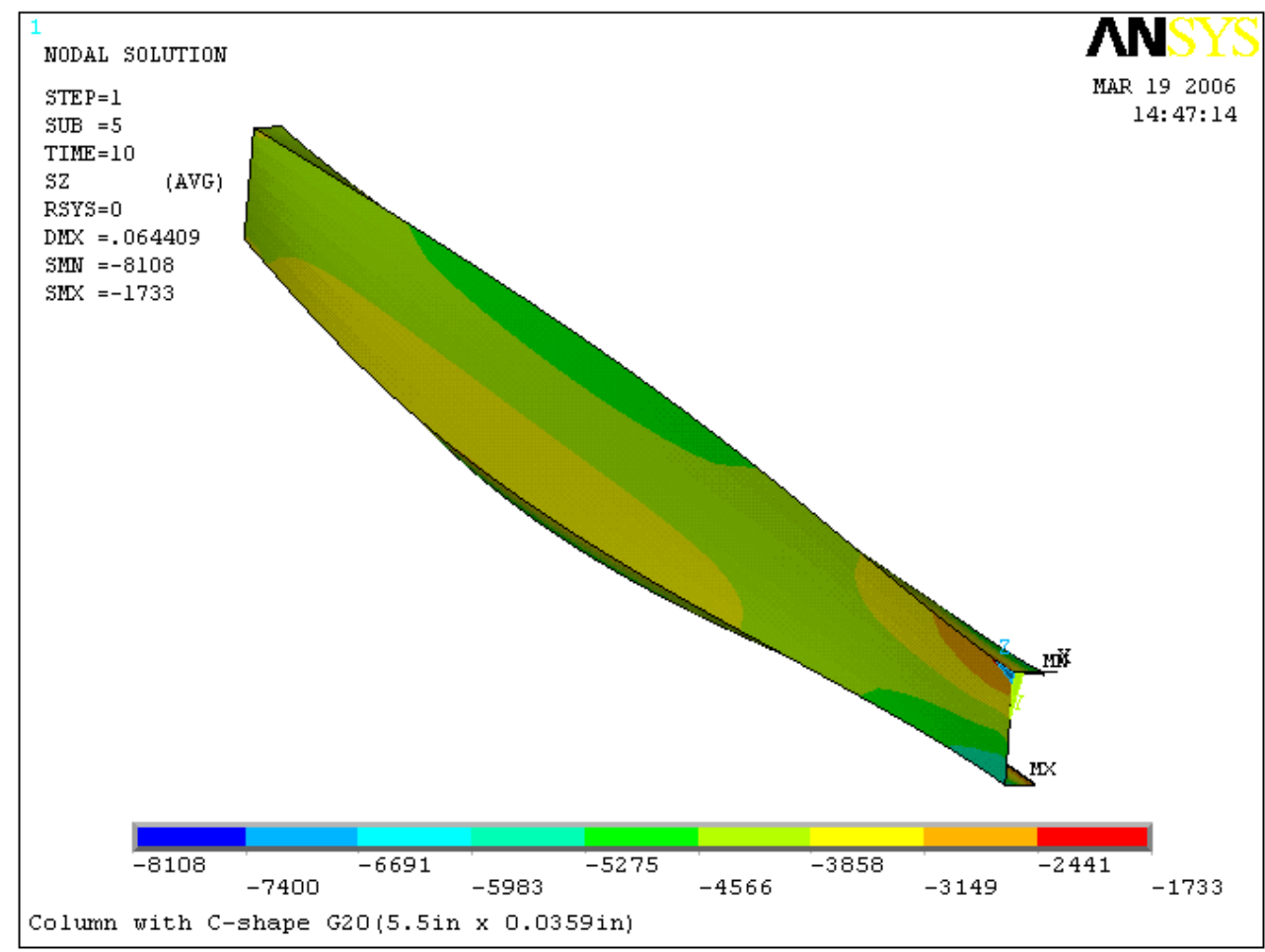

Figure 4.24 Stresses in the back side of C2×6 profile with 20 Gage (units: psi)

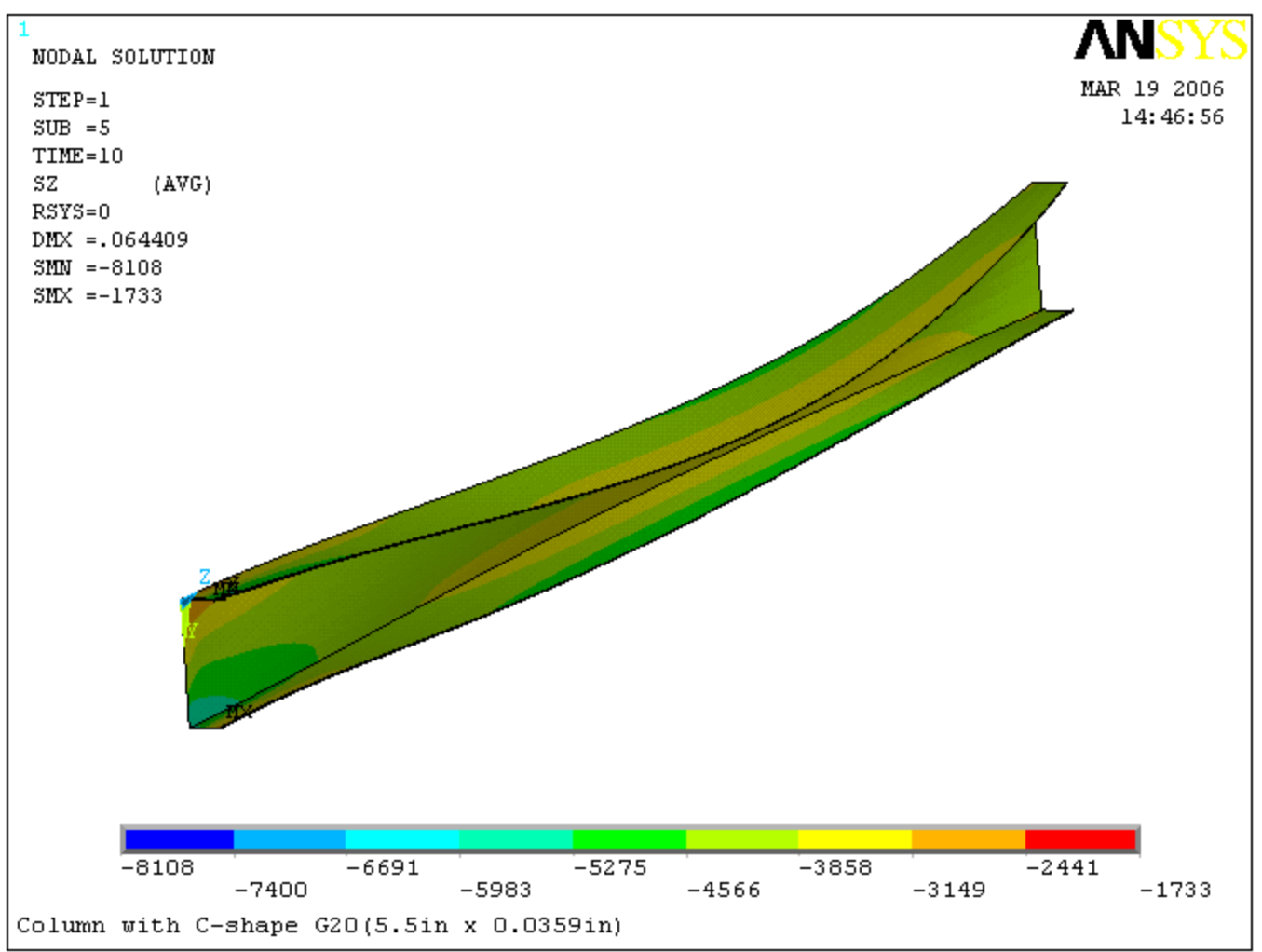

Figure 4.25 Stresses in the front side of C2×6 profile with 20 Gage (units: psi) 
4.2.2.2 Stresses in longitudinal direction of $\mathrm{C}$-shape profile under the load Case 2

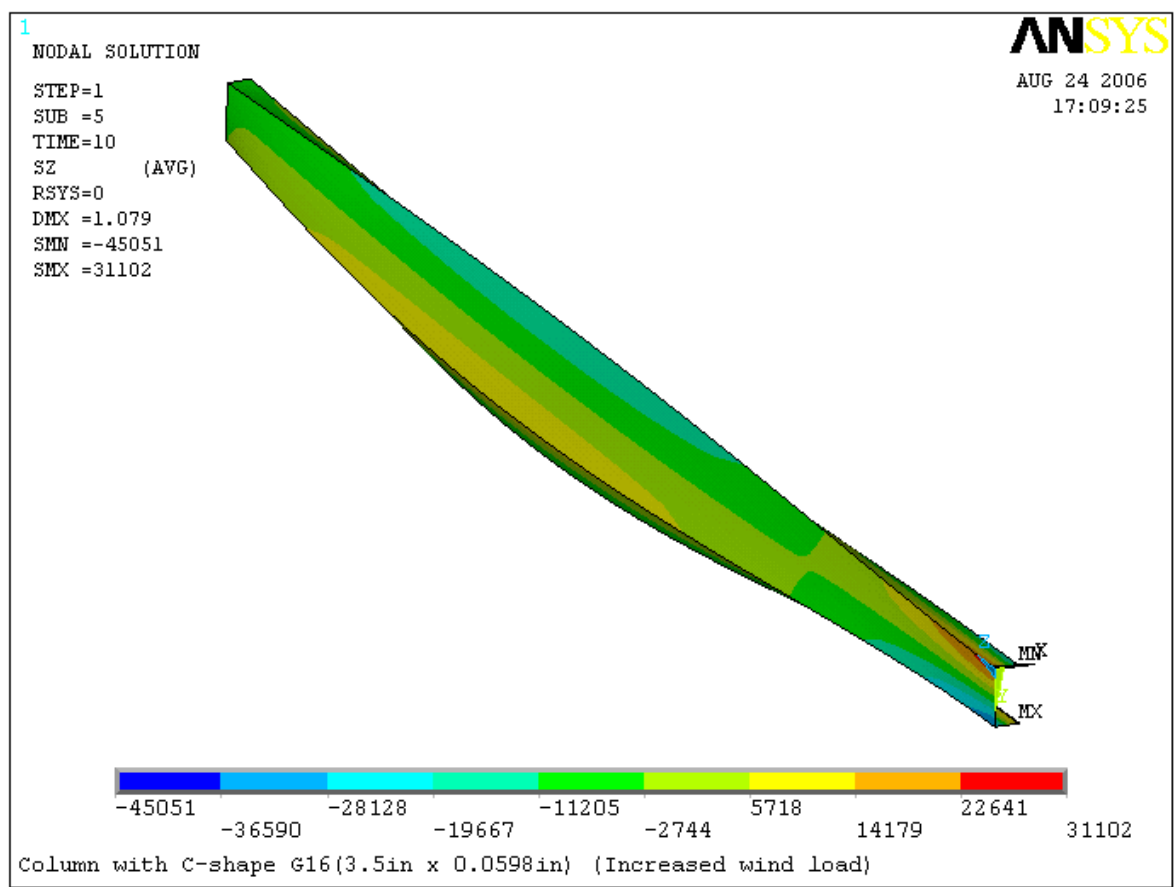

Figure 4.26 Stresses in the back side of C2×4 profile with 16 Gage (units: psi)

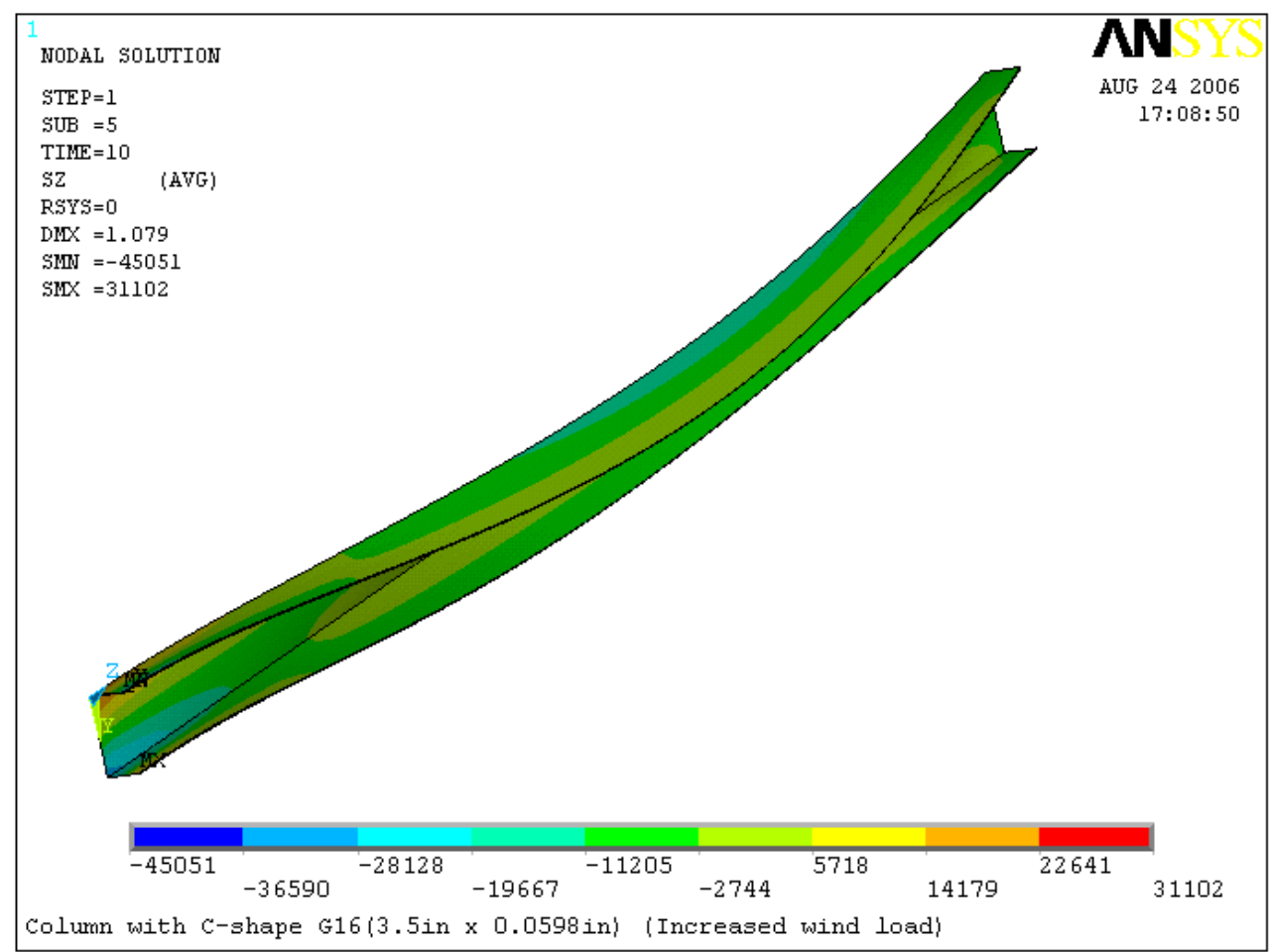

Figure 4.27 Stresses in the front side of $\mathrm{C} 2 \times 4$ profile with 16 Gage (units: psi) 


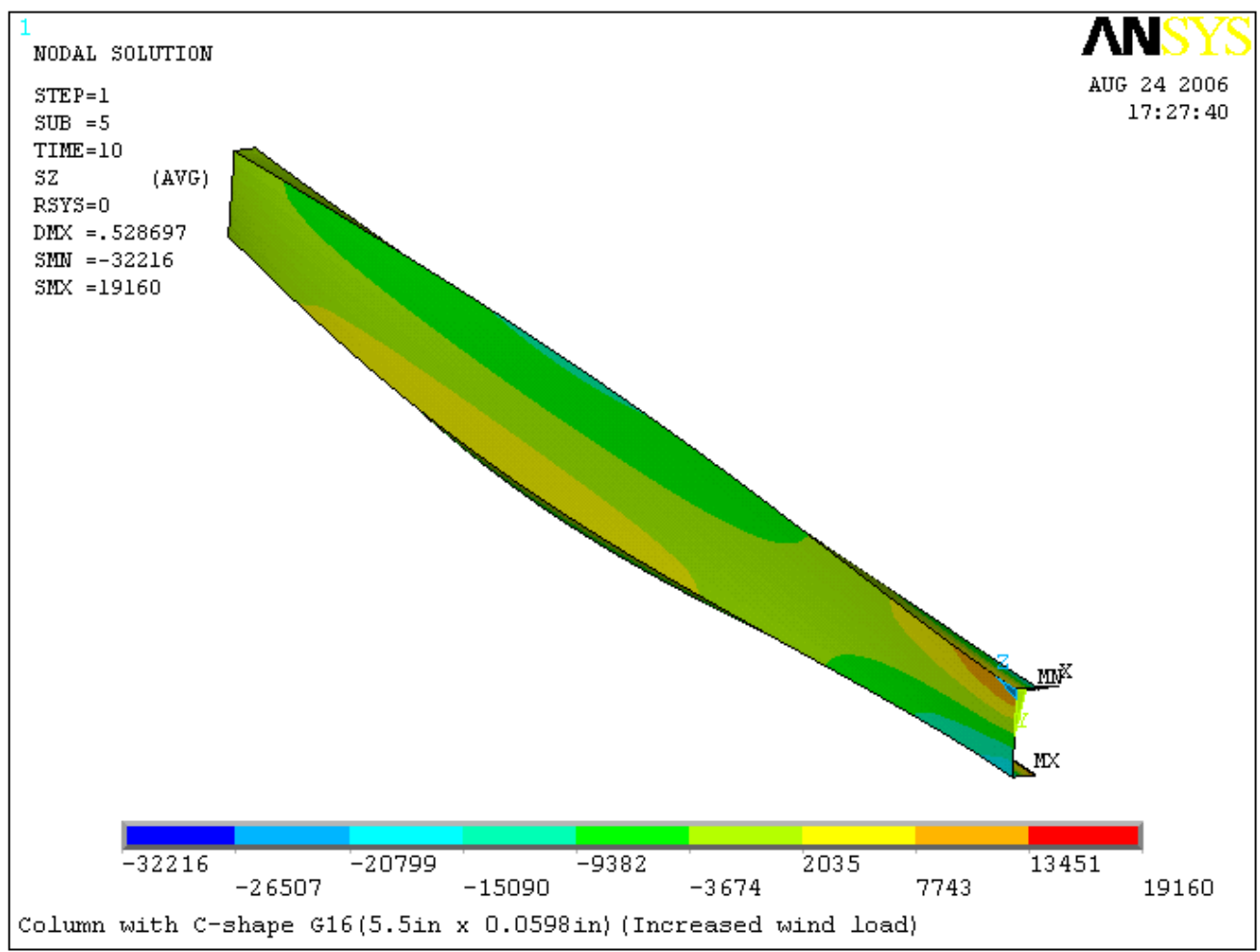

Figure 4.28 Stresses in the back side of C2×6 profile with 16 Gage (units: psi)

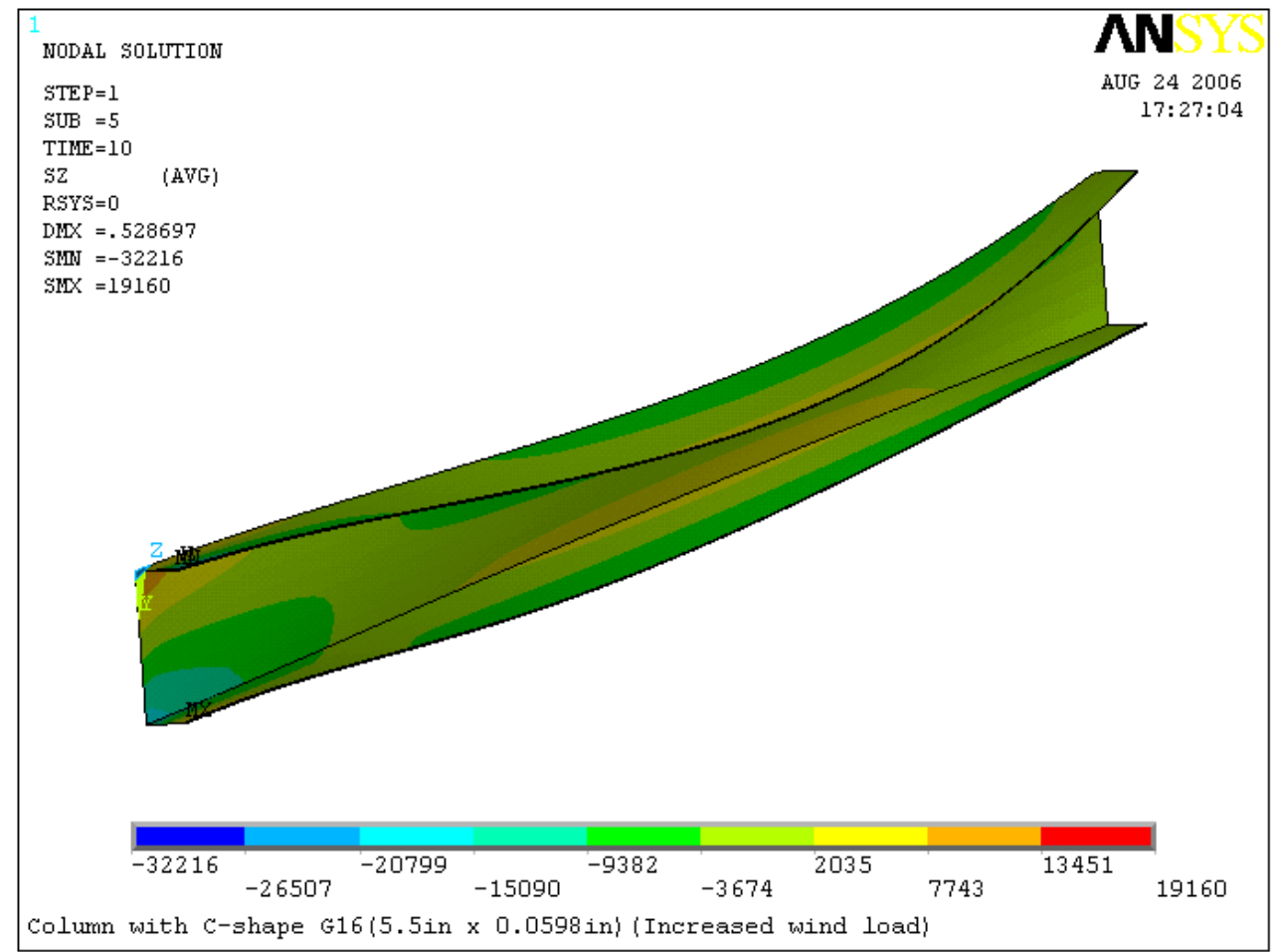

Figure 4.29 Stresses in the front side of C2×6 profile with 16 Gage (units: psi) 
The maximum stresses of the C-shape profiles increased as thickness of the steel decreased, while the maximum stresses of the profiles decreased as the height of channel-web increased. For example, the maximum stresses of the $2 \times 4$ C-shape profile decreased from 6132 psi to 4492 psi when the steel thickness changed from 16 gage to 20 gage. For the same steel thickness, the maximum stresses of the C-shape profile made of 16 gage steel varied from 6132 psi to 4492 psi when the height of the web increased from $3.5 \mathrm{in.}$ to $5.5 \mathrm{in}$.

\subsection{Load Capability of the C-shape Profile under the load Case 1}

The load capabilities of the C-shape profiles were determined from the following factored combinations:

$$
\begin{aligned}
& 1.2 \mathrm{D}+1.6 \mathrm{~L}+0.5\left(\mathrm{~L}_{\mathrm{r}} \text { or } \mathrm{S} \text { or } \mathrm{R}\right) \\
& 1.2 \mathrm{D}+1.6\left(\mathrm{~L}_{\mathrm{r}} \text { or } \mathrm{S} \text { or } \mathrm{R}\right)+(0.5 \mathrm{~L} \text { or } 0.8 \mathrm{~W}) \\
& 1.2 \mathrm{D}+1.6 \mathrm{~W}+0.5 \mathrm{~L}+0.5\left(\mathrm{~L}_{\mathrm{r}} \text { or } \mathrm{S} \text { or } \mathrm{R}\right)
\end{aligned}
$$

Where $\mathrm{D}$ = dead load; $\mathrm{L}$ = live load due to occupancy; $\mathrm{Lr}$ = roof live load; $\mathrm{S}$ = snow load; $\mathrm{R}=$ nominal load due to initial rainwater or ice exclusive of the ponding contribution; and $\mathrm{W}=$ wind load

The initial values of the above loads are: $\mathrm{L}=12.340 \mathrm{psi} ; \mathrm{Lr}=4.930 \mathrm{psi} ; \mathrm{S}=4.930 \mathrm{psi} ; \mathrm{R}=$ $7.400 \mathrm{psi}$; and $\mathrm{W}=0.136 \mathrm{psi}$ 


\subsubsection{Vertical load capability of the C-shape profile}

Vertical load capability of the C-shape profile can be determined from combination (2):

$1.2 \mathrm{D}+1.6 \mathrm{R}+0.8 \mathrm{~W}$

Table 4.2 Vertical load capability (Rain load) of the C-shape profile

\begin{tabular}{ccccc}
\hline \multirow{2}{*}{ Gage \# } & Profile & $\mathbf{R}(\mathbf{p s i})$ & $\begin{array}{c}\text { Maximum positive } \\
\text { stress (Tension) }\end{array}$ & $\begin{array}{l}\text { Maximum negative stress } \\
\text { (Compression) }\end{array}$ \\
\hline Gage 16 16 & $2 \times 4$ & 75.85 & ----- & $\mathbf{2 8 . 0 4 4}$ \\
\cline { 2 - 5 } & $2 \times 6$ & 100.3 & ---- & $\mathbf{2 8 . 0 1 5}$ \\
\hline Gage 20 & $2 \times 4$ & 44.09 & ----- & $\mathbf{2 8 . 0 2 2}$ \\
\cline { 2 - 5 } & $2 \times 6$ & 57.8 & ---- & $\mathbf{2 8 . 0 2 7}$ \\
\hline
\end{tabular}

Note: $1 . \phi F_{\text {steel }}=0.85 \times 33=28.05 \mathrm{ksi}$

2. Dead load and wind load are constants.

\subsubsection{Wind load capability of the C-shape profile}

Wind load capability of the C-shape profile can be determined from combination (3):

$1.2 \mathrm{D}+1.6 \mathrm{~W}+0.5 \mathrm{~L}+0.5 \mathrm{~S}$

Table 4.3 Horizontal load capability (Wind load) of the C-shape profile

\begin{tabular}{|c|c|c|c|c|c|}
\hline \multirow[b]{2}{*}{ Gage \# } & \multirow[b]{2}{*}{ Profile } & \multirow[b]{2}{*}{$\mathrm{W}(\mathrm{psi})$} & \multirow{2}{*}{$\begin{array}{c}\text { Maximum } \\
\text { deformation } \\
\text { (inches) }\end{array}$} & \multicolumn{2}{|c|}{ Stress in steel (ksi) } \\
\hline & & & & $\begin{array}{l}\text { Maximum positive } \\
\text { stress (Tension) }\end{array}$ & $\begin{array}{l}\text { Maximum negative } \\
\text { stress (Compression) }\end{array}$ \\
\hline \multirow{2}{*}{ Gage 16} & $2 \times 4$ & 0.860 & 0.6823 & 20.112 & 28.043 \\
\hline & $2 \times 6$ & 1.228 & 0.4757 & 17.753 & 28.035 \\
\hline \multirow{2}{*}{ Gage 20} & $2 \times 4$ & 0.392 & 0.6538 & 15.845 & 28.031 \\
\hline & $2 \times 6$ & 0.571 & 0.4261 & 13.078 & 28.049 \\
\hline
\end{tabular}

Note: $1 . \phi F_{\text {steel }}=0.85 \times 33=28.05 \mathrm{ksi}$

2. Dead load, live load and snow load are constants. 


\subsubsection{Wind capability of the C-shape profile based on deflection limitation}

Deflection capability of the C-shape profile can be determined from combination:

$\mathrm{D}+\mathrm{W}+\mathrm{L}+\mathrm{S}$ (or $\mathrm{Lr}$ )

Table 4.4 Deformation vs. wind load (W) of the C-shape profile

\begin{tabular}{lllccc}
\hline \multirow{2}{*}{ Gage \# } & Profile & W(psi) & Maximum & deformation & \multicolumn{2}{c}{ Stress in steel (ksi) } \\
\cline { 5 - 6 } & & & (inches) & $\begin{array}{c}\text { Maximum positive } \\
\text { stress (Tension) }\end{array}$ & $\begin{array}{c}\text { Maximum negative } \\
\text { stress (Compression) }\end{array}$ \\
\hline \multirow{2}{*}{ Gage 16 16} & $2 \times 4$ & 0.604 & $\mathbf{0 . 3 0}$ & 6.078 & 15.060 \\
\cline { 2 - 6 } & $2 \times 6$ & 1.22 & $\mathbf{0 . 3 0}$ & 9.177 & 19.216 \\
\hline \multirow{2}{*}{ Gage 20 } & $2 \times 4$ & 0.283 & $\mathbf{0 . 3 0}$ & 2.784 & 17.038 \\
\cline { 2 - 6 } & $2 \times 6$ & 0.638 & $\mathbf{0 . 3 0}$ & 6.393 & 22.338 \\
\hline
\end{tabular}

Note: $1 . \phi F_{\text {steel }}=0.85 \times 33=28.05 \mathrm{ksi}$

2. Dead load, live load and snow load are constants.

3. The limitation of C-shape deformation was $\mathrm{L} / 360=0.3$ inch.

The capacities of the C-shape profiles under the load Case 2 were not studied herein because C-shape profiles under the normal loads were unacceptable (AISC LRFD Specifications). 


\section{CHAPTER 5}

\section{MODELING AND ANALYSIS OF DELTA-SHAPE COLUMNS}

\subsection{Description of Input and Modeling of Delta-shape Columns}

Delta-shaped column was developed recently by Dr. Jan Kosny at ORNL. The column has a larger stiffness in the cross section. The Delta-shaped column could be made with welds at joint or without welds at joint. This chapter presents the results for both welded and unwelded conditions.

\subsubsection{Dimensions and modeling of the Delta-shape column}

Figure 5.1 shows the typical cross-section of the Delta-shaped column.

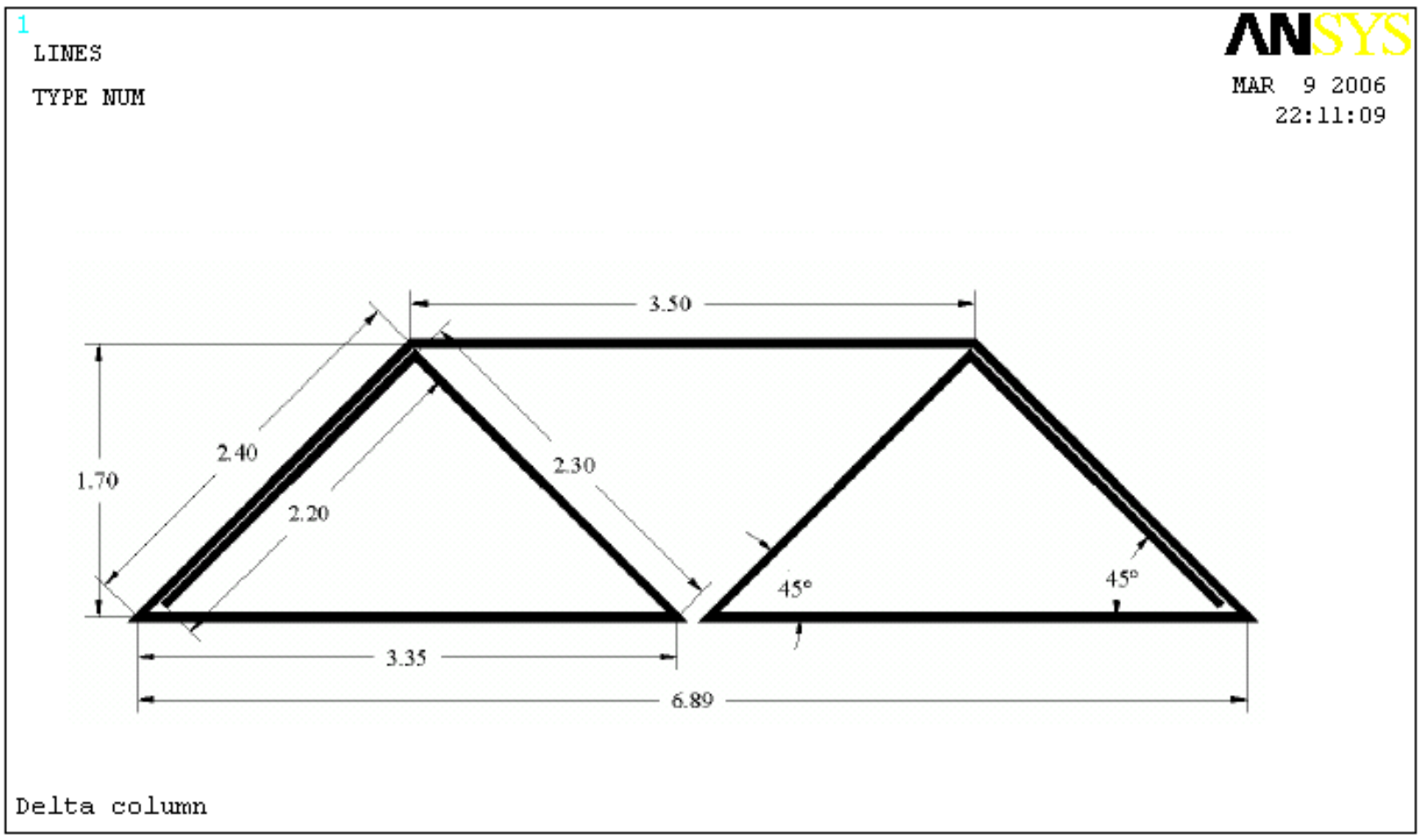

Figure 5.1 Cross-section of the Delta-shape column (unit: inches) 


\subsubsection{Finite element model of the Delta-shape column}

Shell elements (Shell181) were used to model the Delta-shape column. Figure 5.2 shows the elevation of the Delta-shape column model. The column was divided into $54-2$ inches elements in height. Figure 5.3 shows the three-dimensional view of the Delta-shape column model. The model was restrained with pin supports at the top of the column and fix supports at the bottom except the rotation about $\mathrm{X}$ direction, as shown in Figure. 5.4.

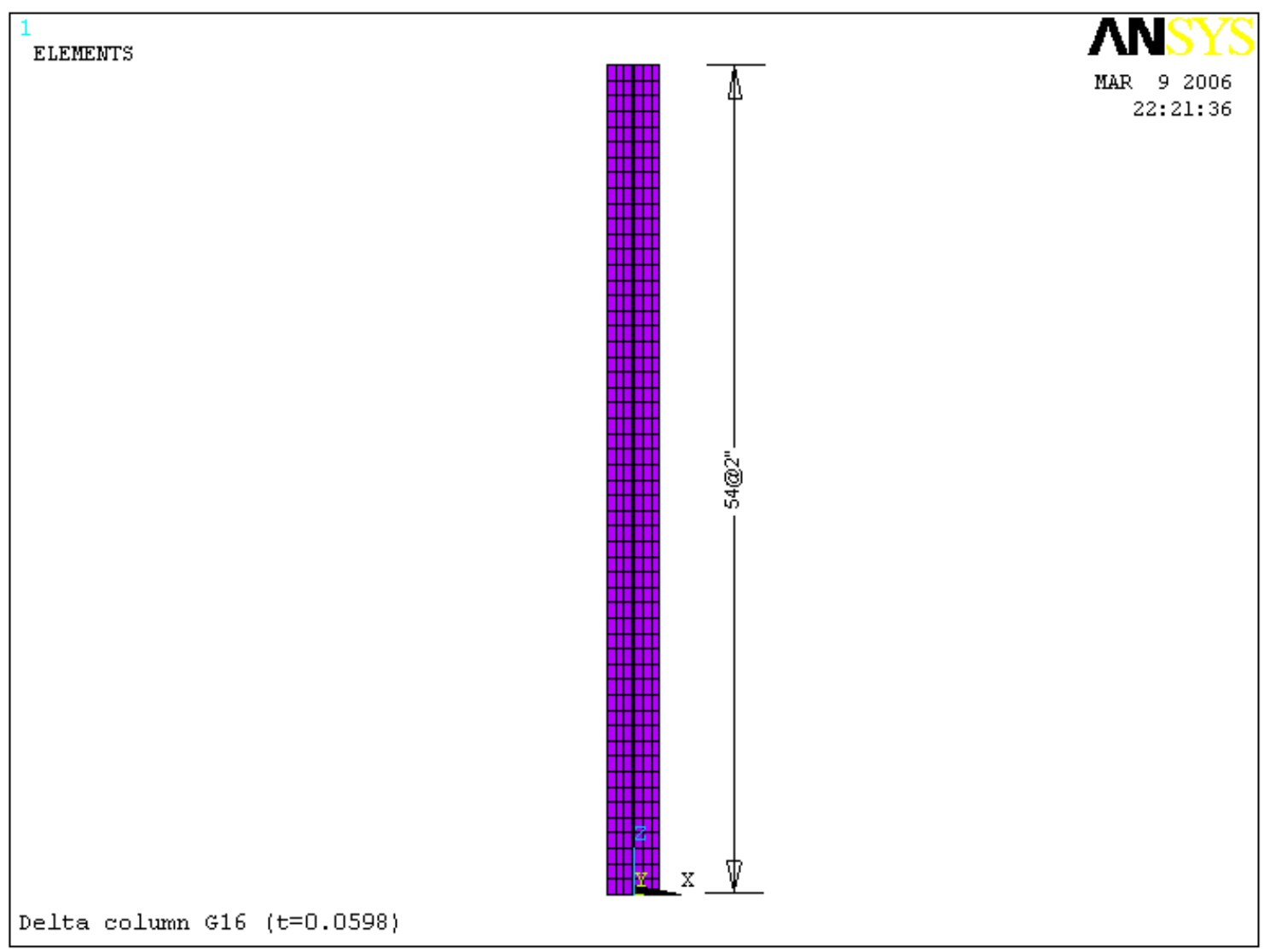

Figure 5.2 Elevation of the Delta-shape column 


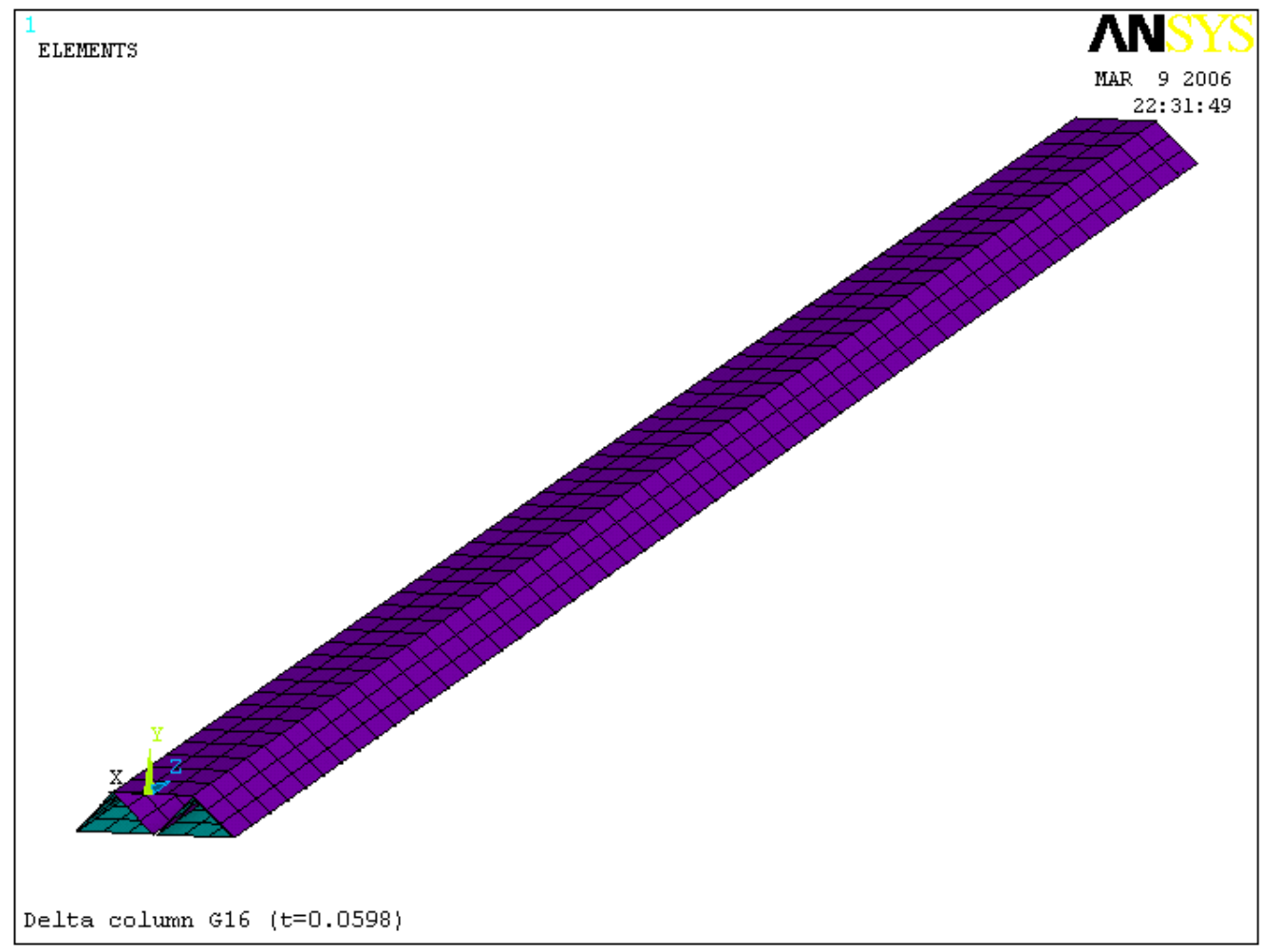

Figure 5.3 3-D Delta-shape column model

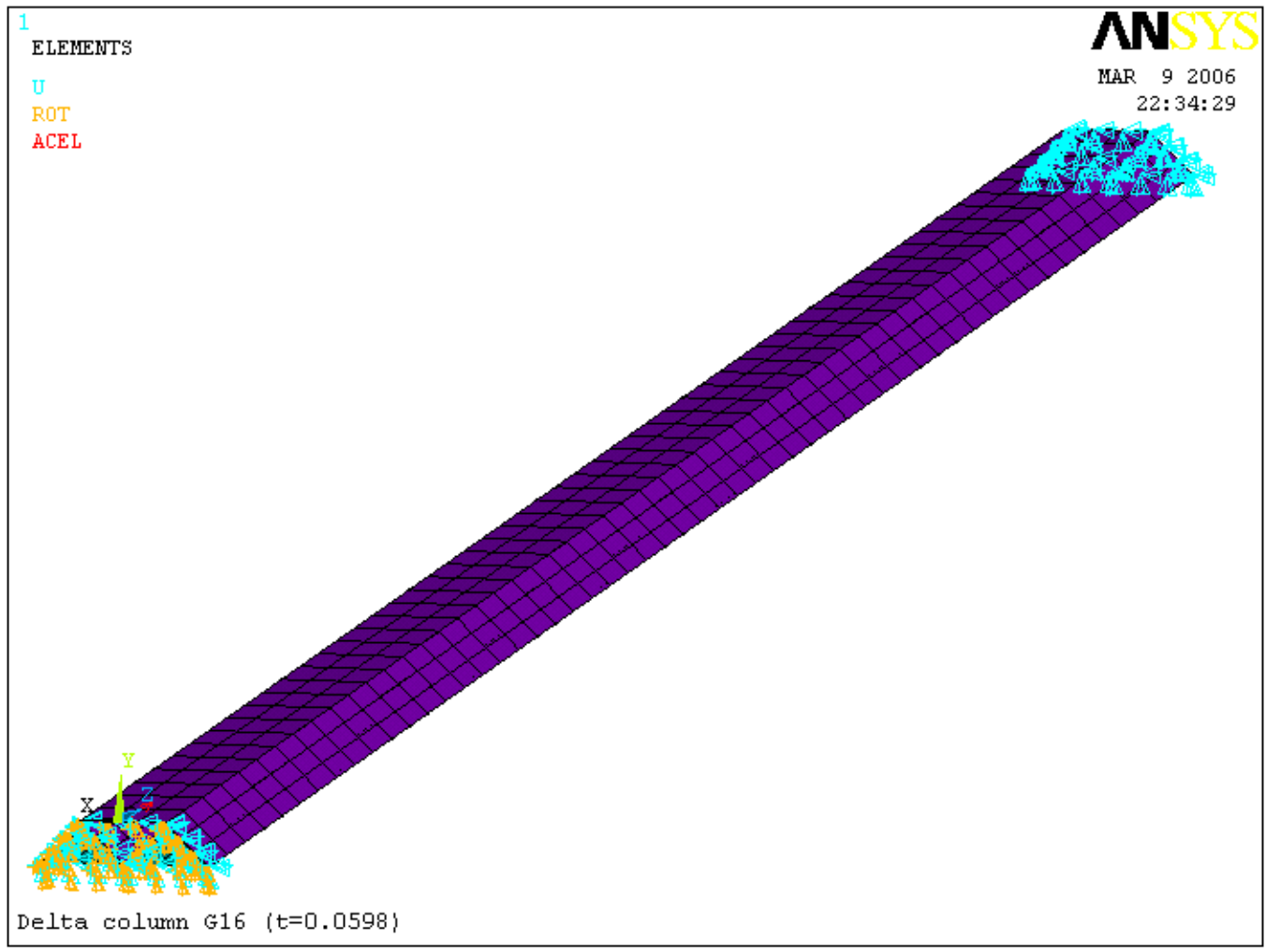

Figure 5.4 Delta-shape column model with end restraints 


\subsubsection{Loads}

Table 5.1 Applied load of the Delta-shape columns

\begin{tabular}{ccccc}
\hline \multirow{2}{*}{ Gage \# } & Dead load & Live load & \multicolumn{2}{c}{ Wind load (psi) } \\
\cline { 4 - 5 } & ( lbs) & (lb/in) & Case 1 & Case 2 \\
\hline Gage 16 & 43.962 & 79.503 & 0.1360 & 1.3989 \\
\hline Gage 18 & 35.14 & 79.503 & 0.1360 & 1.3989 \\
\hline Gage 20 & 26.392 & 79.503 & 0.1360 & 1.3989 \\
\hline
\end{tabular}

Note:

1. Case 1 denotes columns carry the wind load based on column area only;

2. Case 2 denotes columns carry the wind load based on 36 in wide tributary area.

Figure 5.5 was an example of the Delta-shape column with loads. It was assumed that the column will resist wind load on its front side.

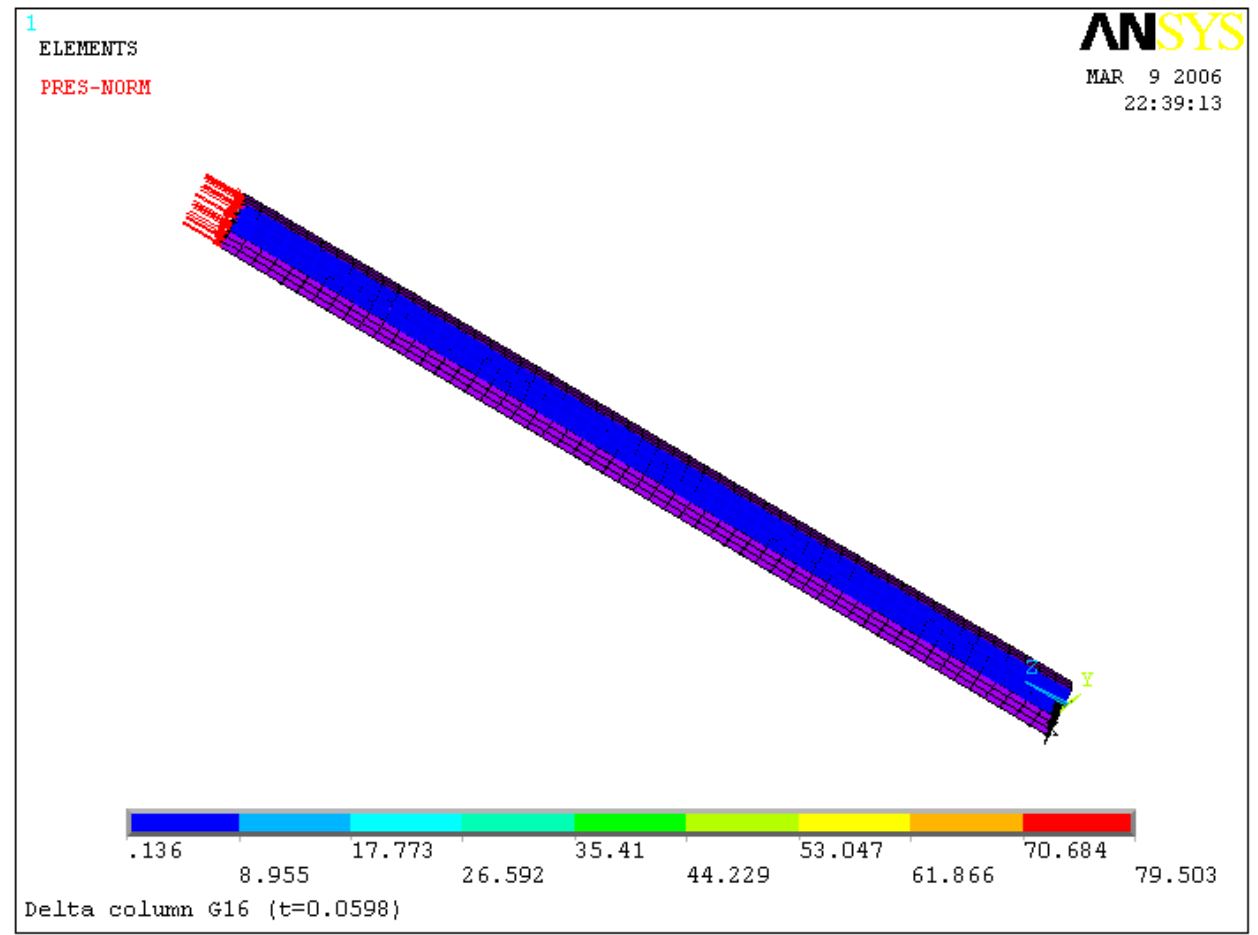

Figure 5.5 Loads on the column with Delta-shape

(Positive values denote the pressure act into the areas) 


\subsection{Analytical Results of the Delta-shape Column}

\subsubsection{Deformation}

Figures 5.6 through 5.8 show the deformation of Delta-shape columns with Gage 16, 18 and Gage 20 under the load Case 1. Figures 5.9 through 5.11 show the deformation of Delta-shape column with Gage 16, 18 and Gage 20 under the load Case 2.

\subsubsection{Deformation of Delta-shape column under the load Case 1}

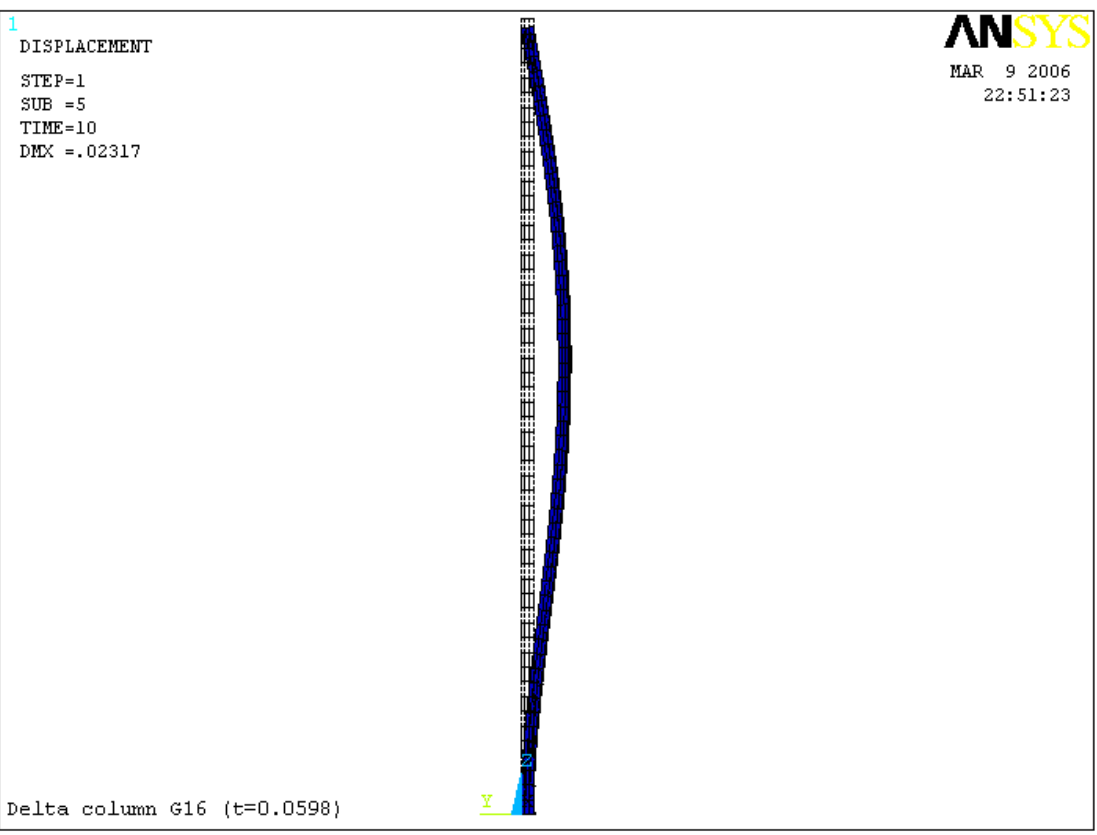

Figure 5.6 Deformation of the Delta-shape column with 16 Gage (unit: inches) 


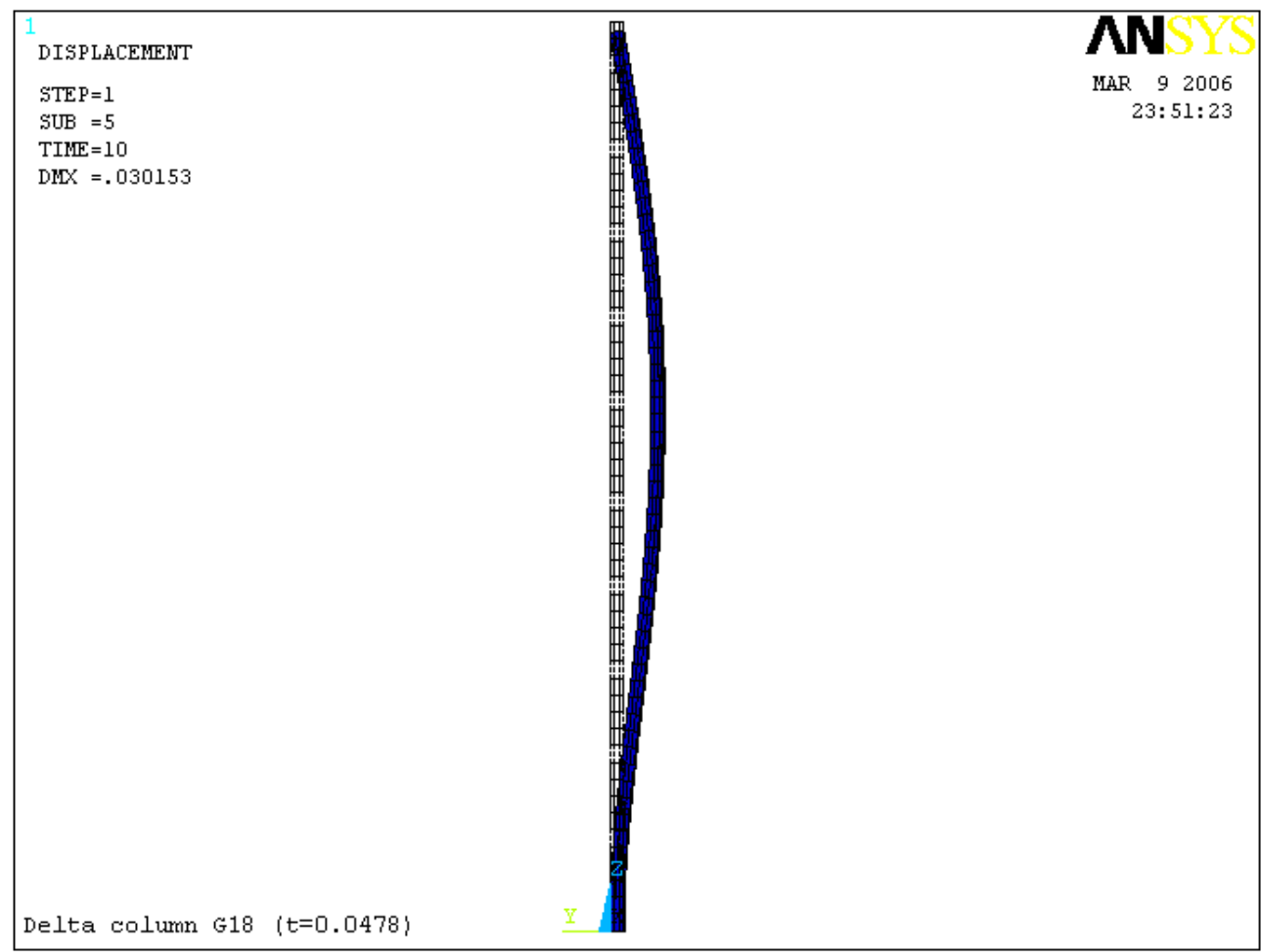

Figure 5.7 Deformation of the Delta-shape column with 18 Gage (unit: inches)

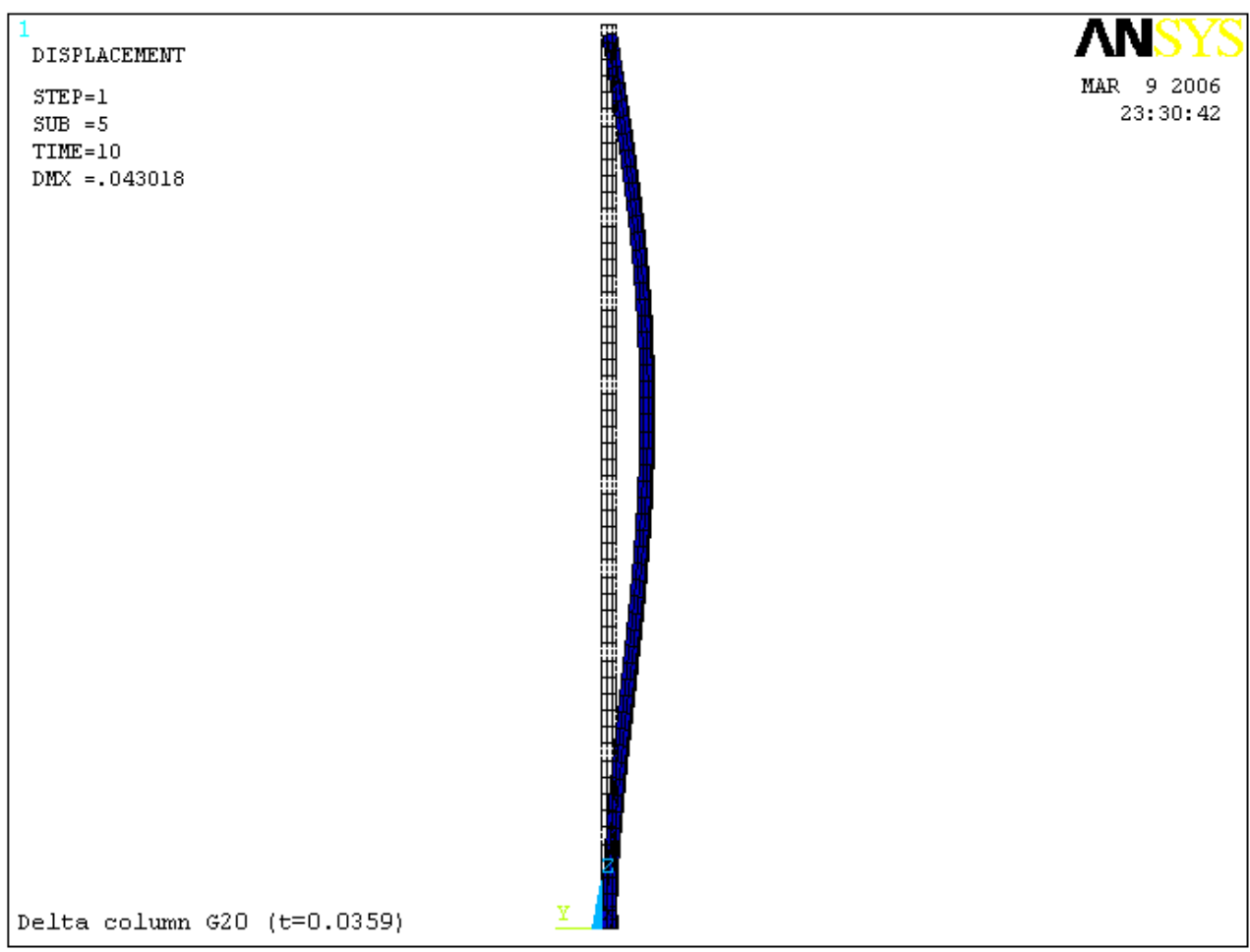

Figure 5.8 Deformation of the Delta-shape column with 20 Gage (unit: inches) 
5.2.1.2 Deformation of Delta-shape column under the load Case 2

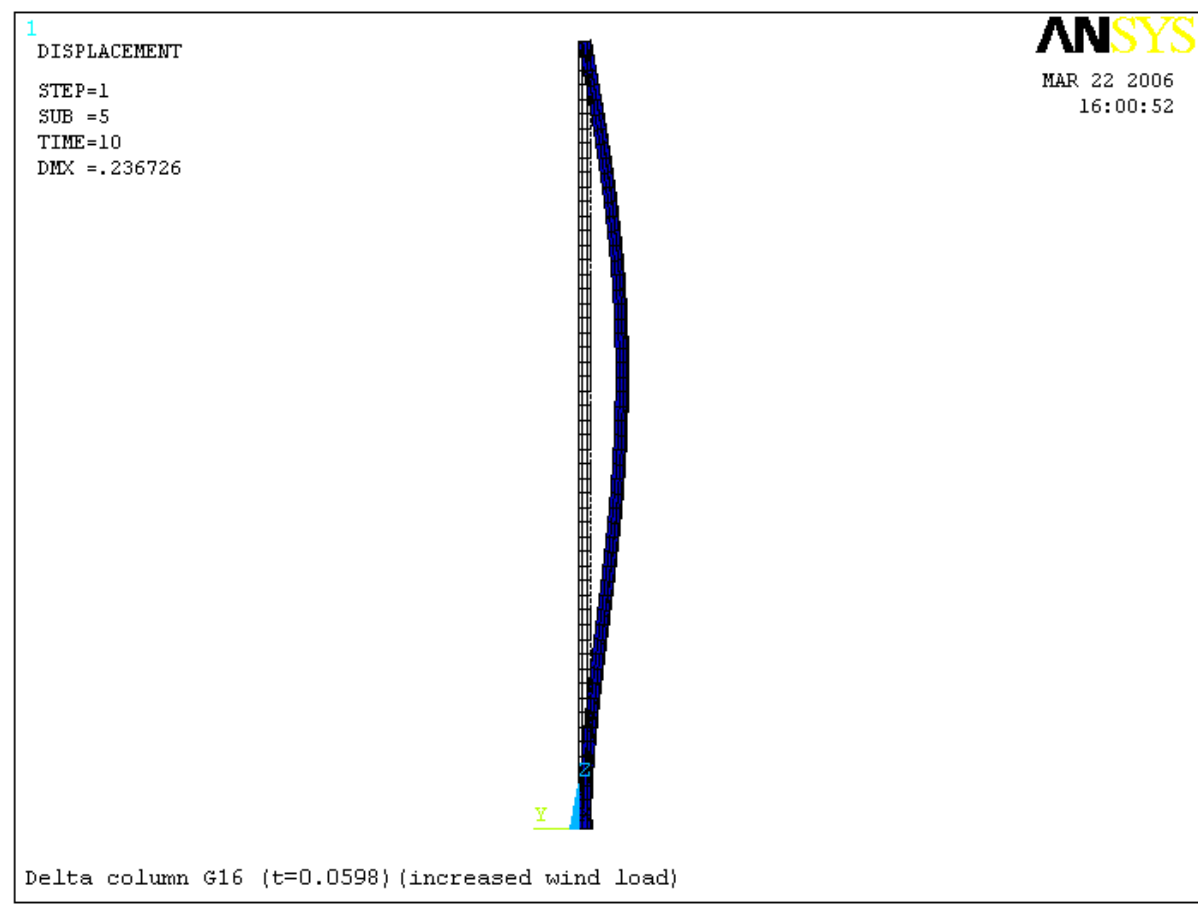

Figure 5.9 Deformation of the Delta-shape column with 16 Gage (unit: inches)

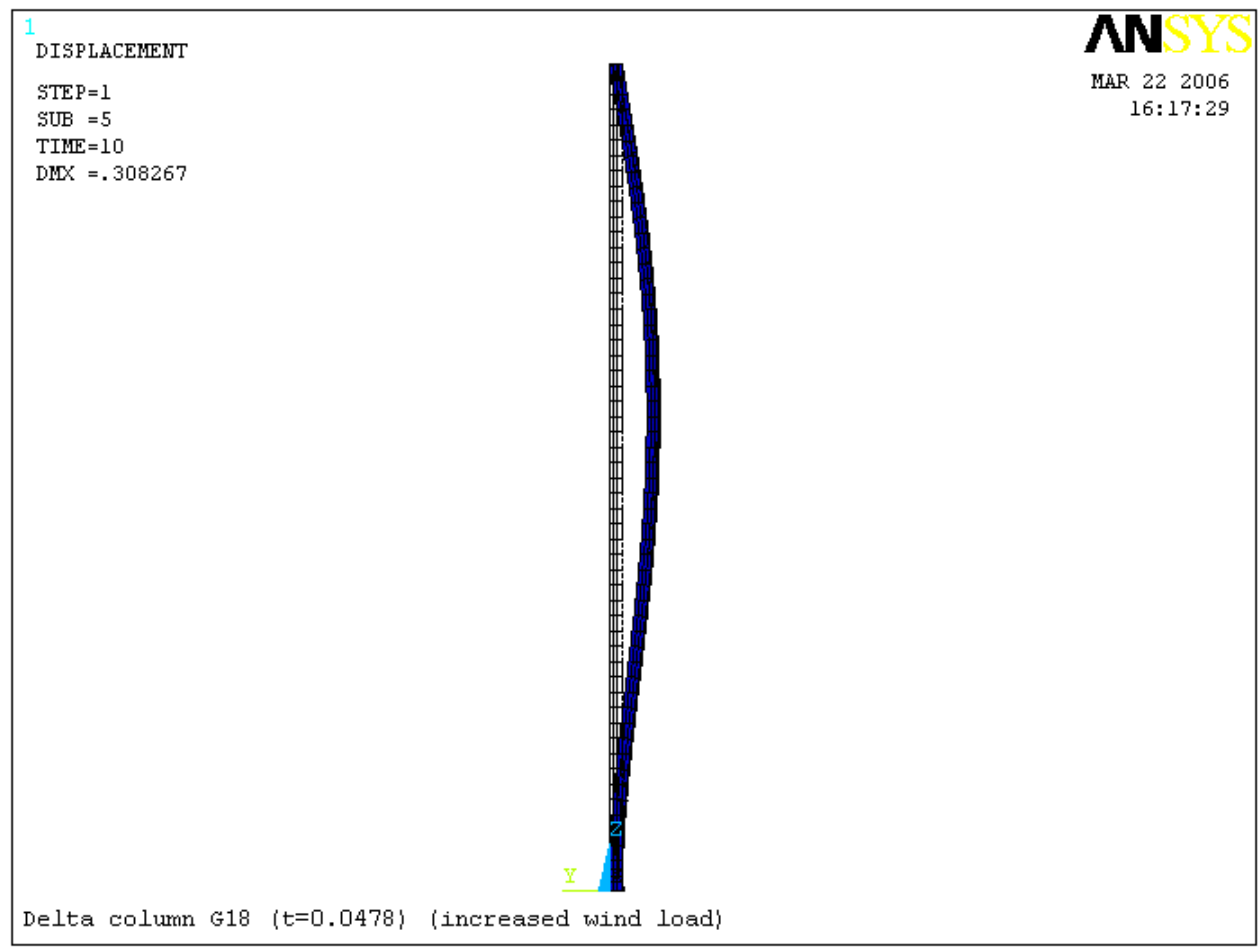

Figure 5.10 Deformation of the Delta-shape column with 18 Gage (unit: inches) 


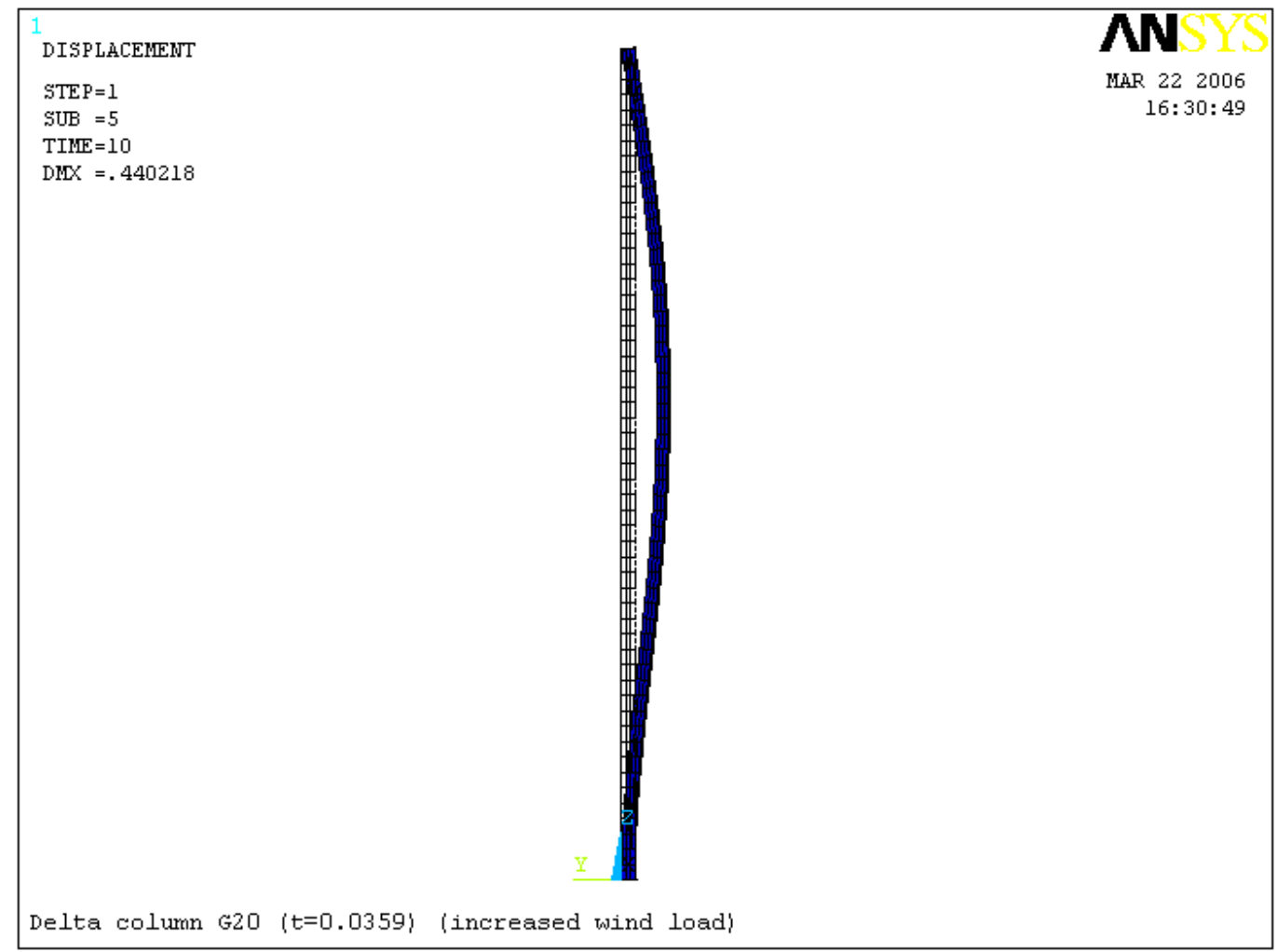

Figure 5.11 Deformation of the Delta-shape column with 20 Gage (unit: inches)

The Delta-shape column clearly had a strong axis and weak axis in the cross-section. The deformation occurred predominantly in the lateral direction, or about the weak axis. Little twisting was observed for all of the column dimensions and load cases studied. The maximum deformation of the Delta columns increased as thickness of steel decreased. For example, the maximum deformation of the Delta columns increased from $0.02317 \mathrm{in.} \mathrm{to} 0.0430 \mathrm{in}$. as the steel thickness changed from 16 gage to 20 gage. Under load Case 2, due to a larger lateral deformation of column, the deformation limit L/360 was the controlling criteria.

\subsubsection{Stresses of the Delta-shape columns}

Figures 5.12 through 5.17 show the stresses of Delta-shape columns made of 16, 18 and 20 gage steel under the load Case 1. Figures 5.18 through 5.23 show the stresses of Delta-shape column made of 16, 18 and 20 gage steel under the load Case 2. 
5.2.2.1 Stresses in longitudinal direction of Delta-shape column under load Case 1

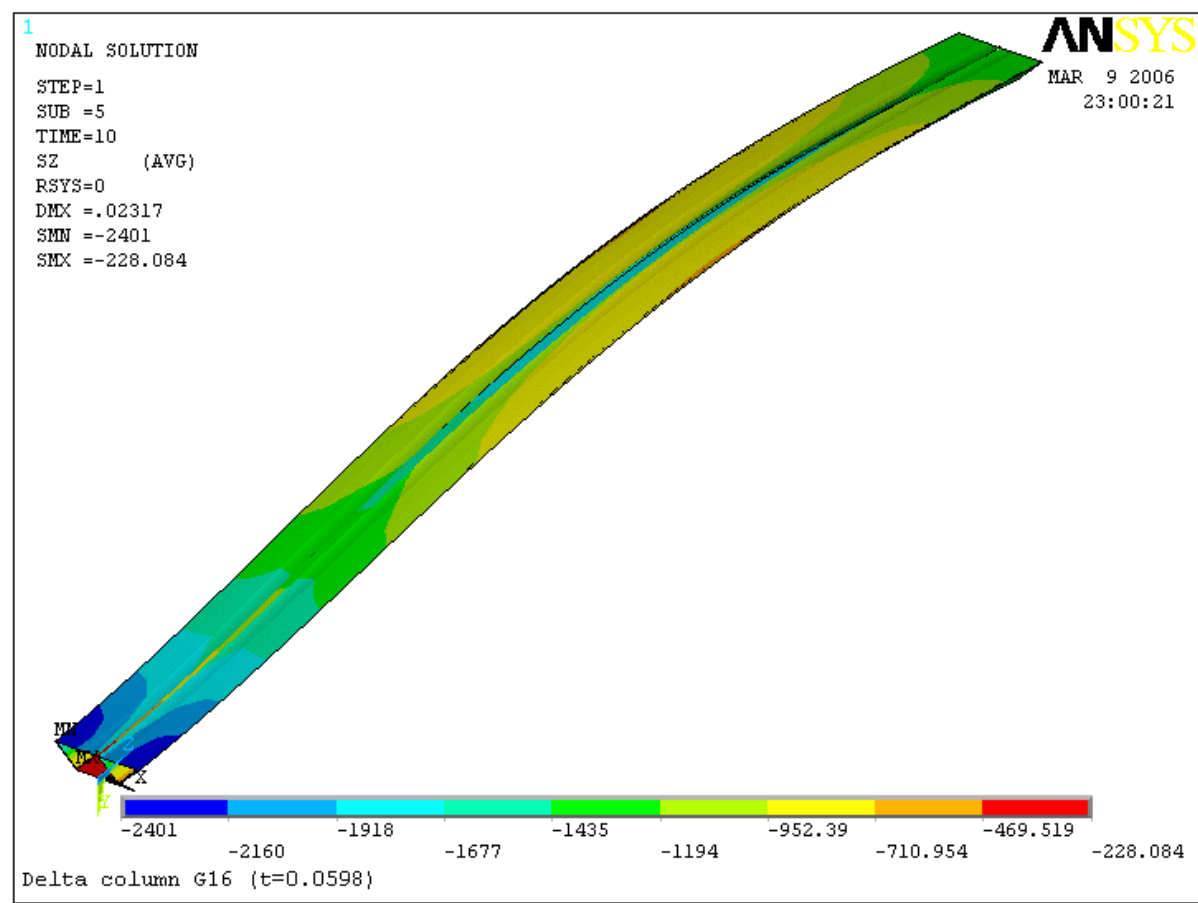

Figure 5.12 Stresses in the back side of the delta-shape column with 16 Gage (unit: psi)

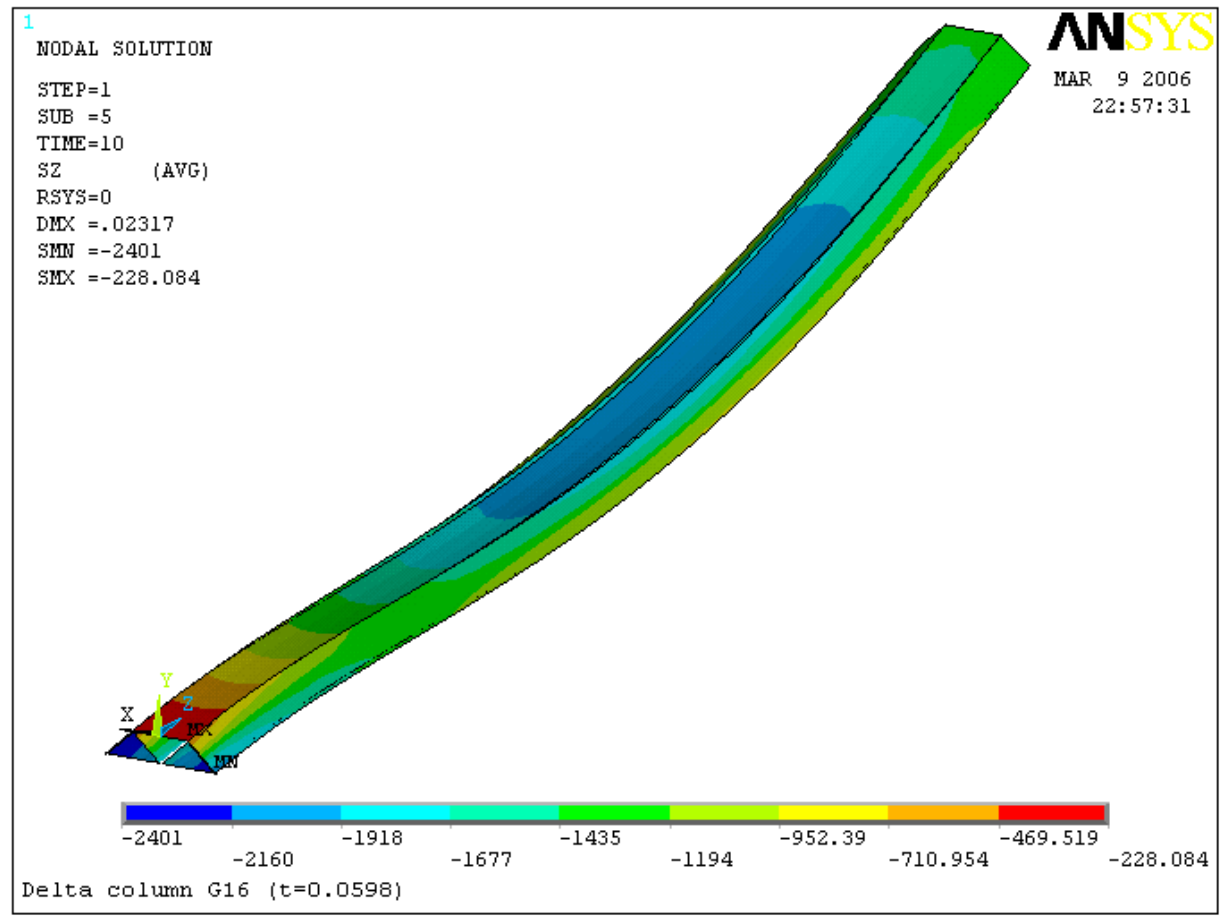

Figure 5.13 Stresses in the front side of the delta-shape column with 16 Gage (unit: psi) 


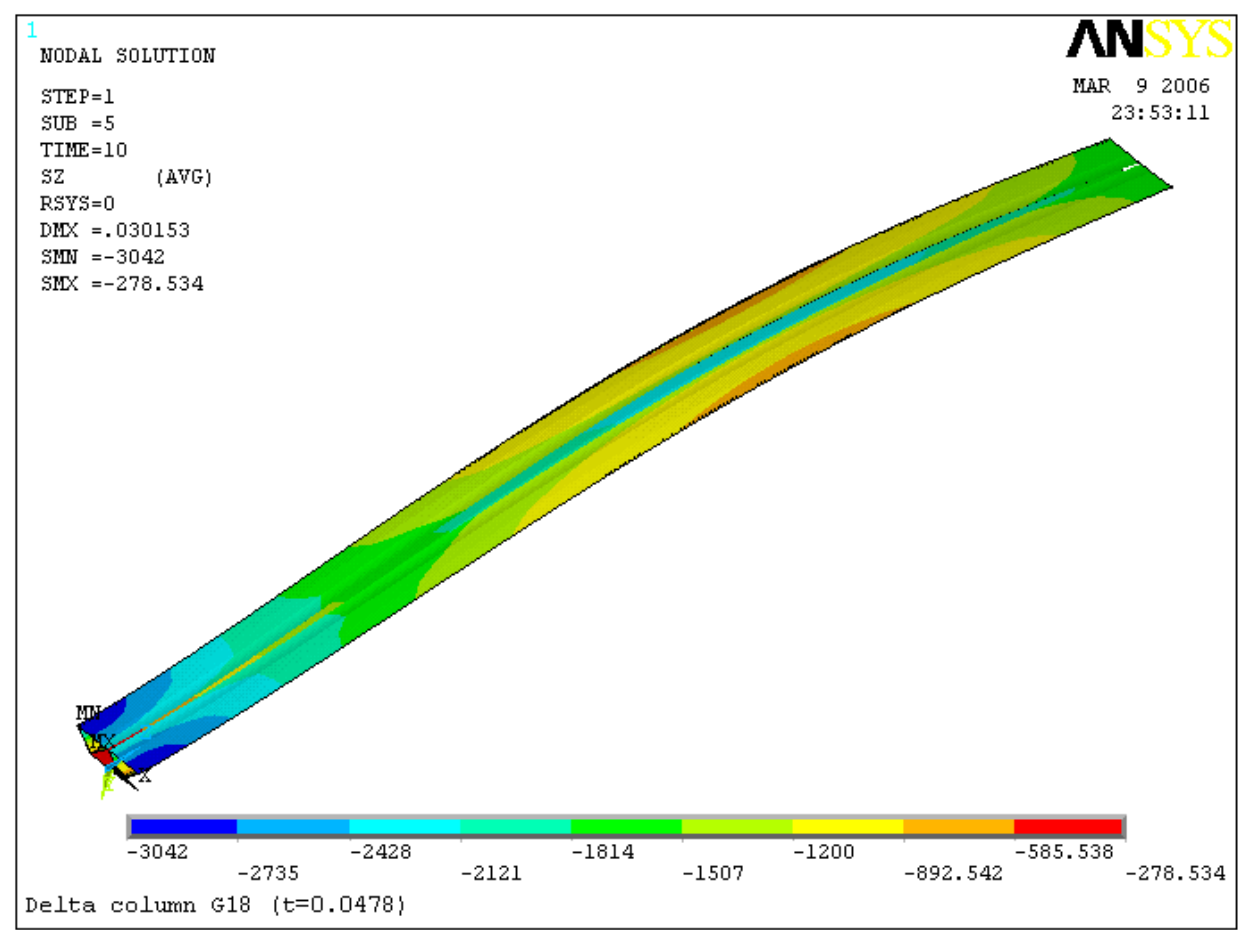

Figure 5.14 Stresses in the back side of the delta-shape column with 18 Gage (unit: psi)

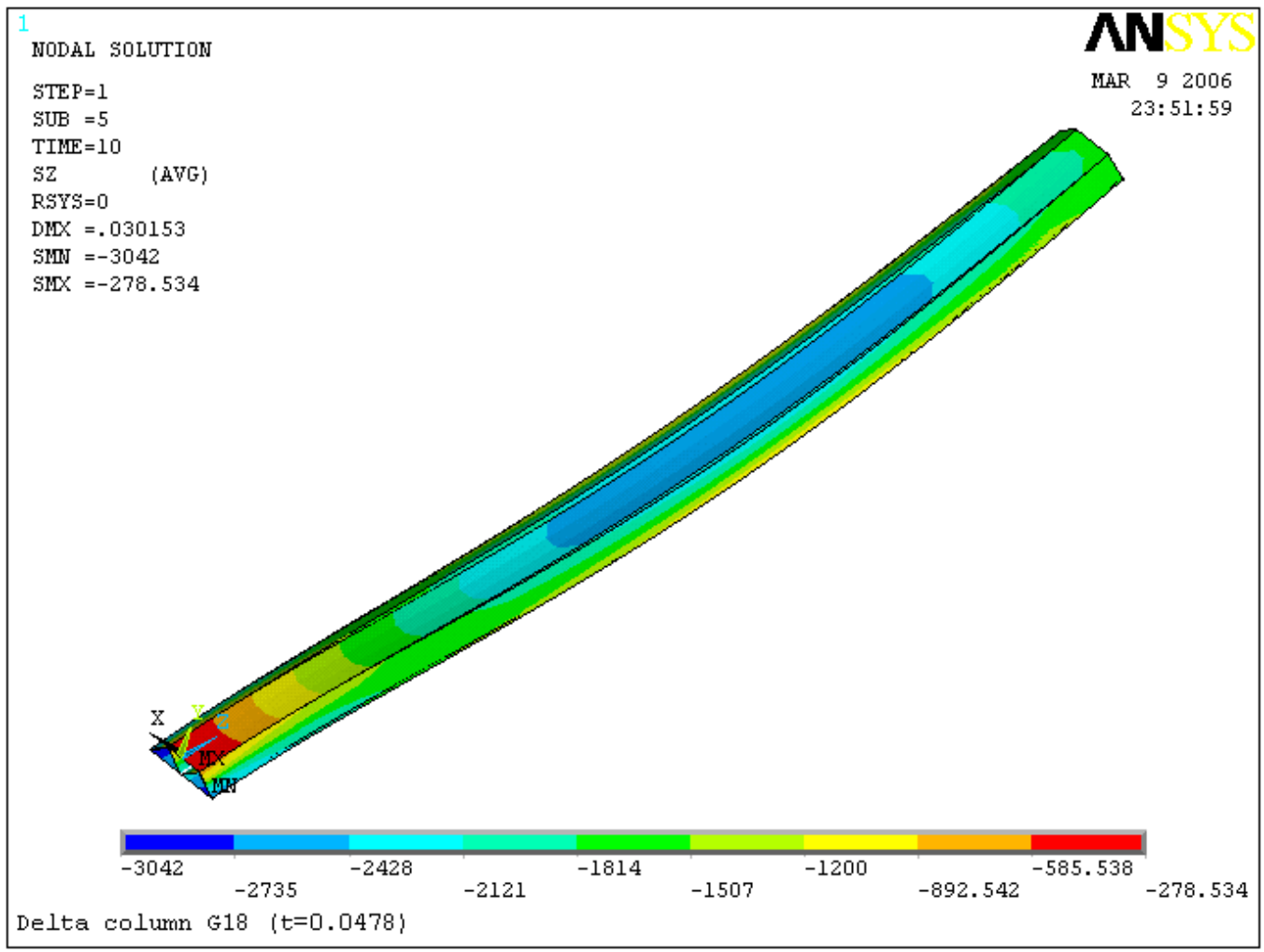

Figure 5.15 Stresses in the front side of the delta-shape column with 18 Gage (unit: psi) 


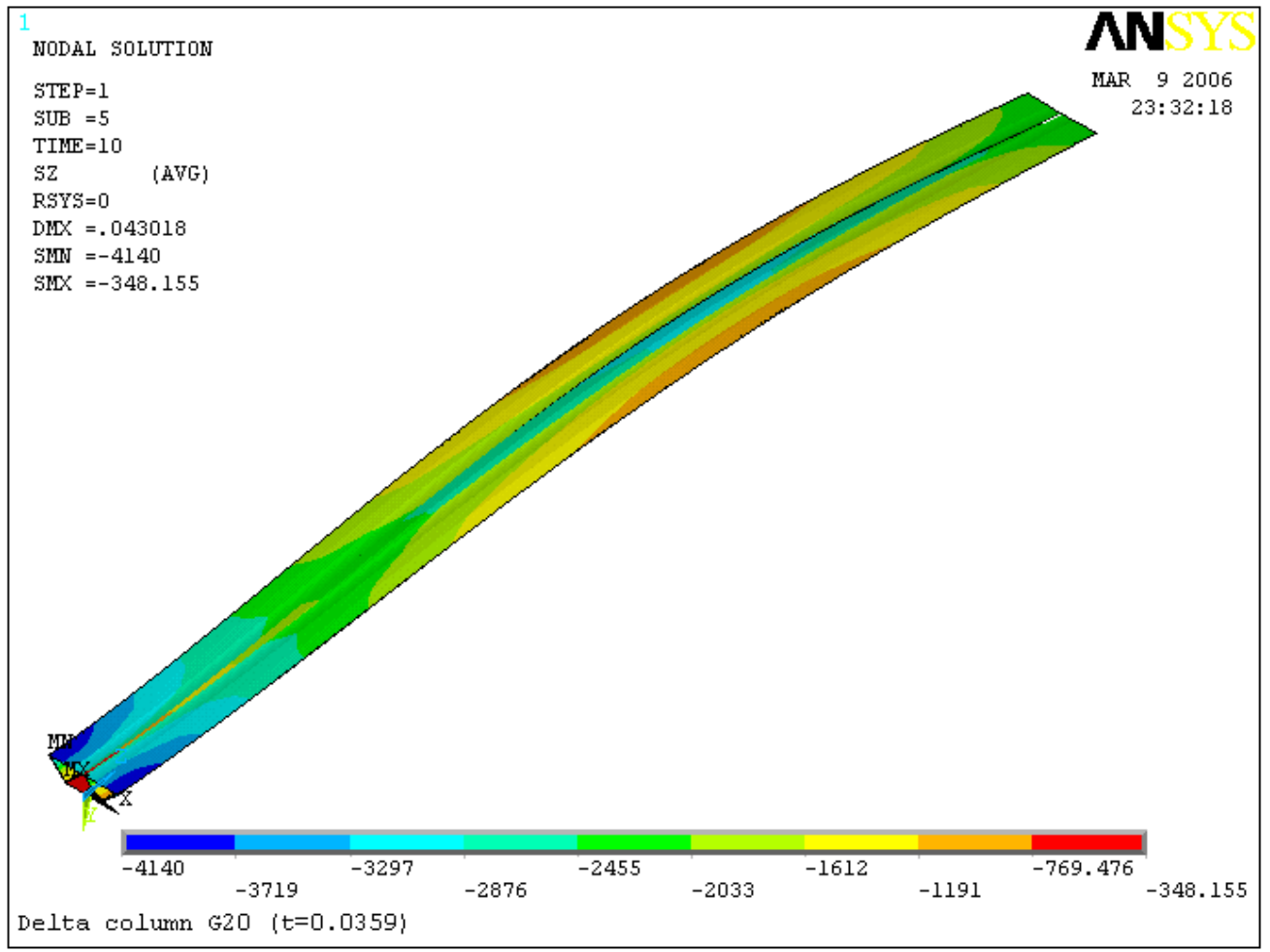

Figure 5.16 Stresses in the back side of the delta-shape column with 20 Gage (unit: psi)

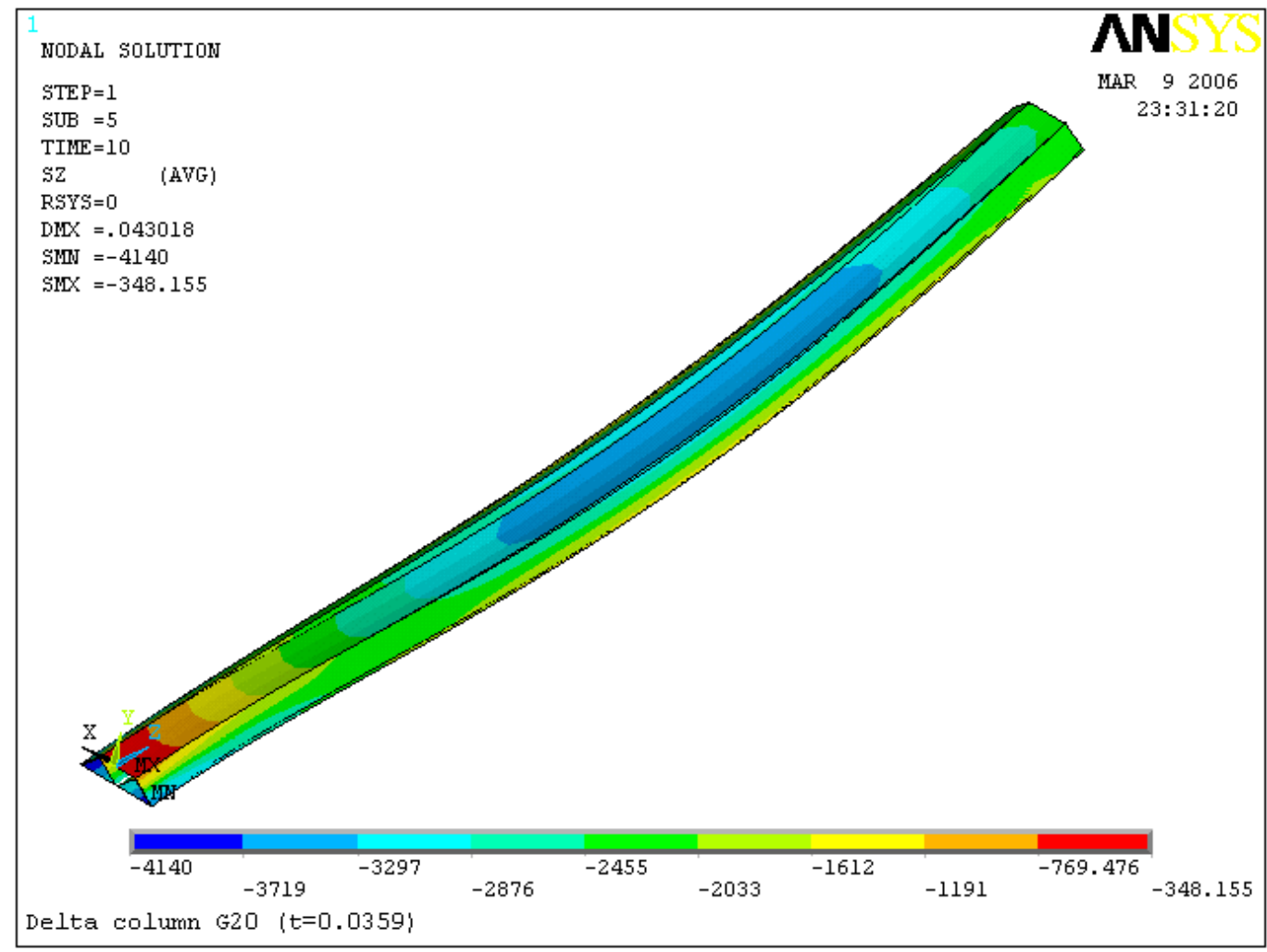

Figure 5.17 Stresses in the front side of the delta-shape column with 20 Gage (unit: psi) 
5.2.2.2 Stresses in longitudinal direction of Delta-shape column under load Case 2

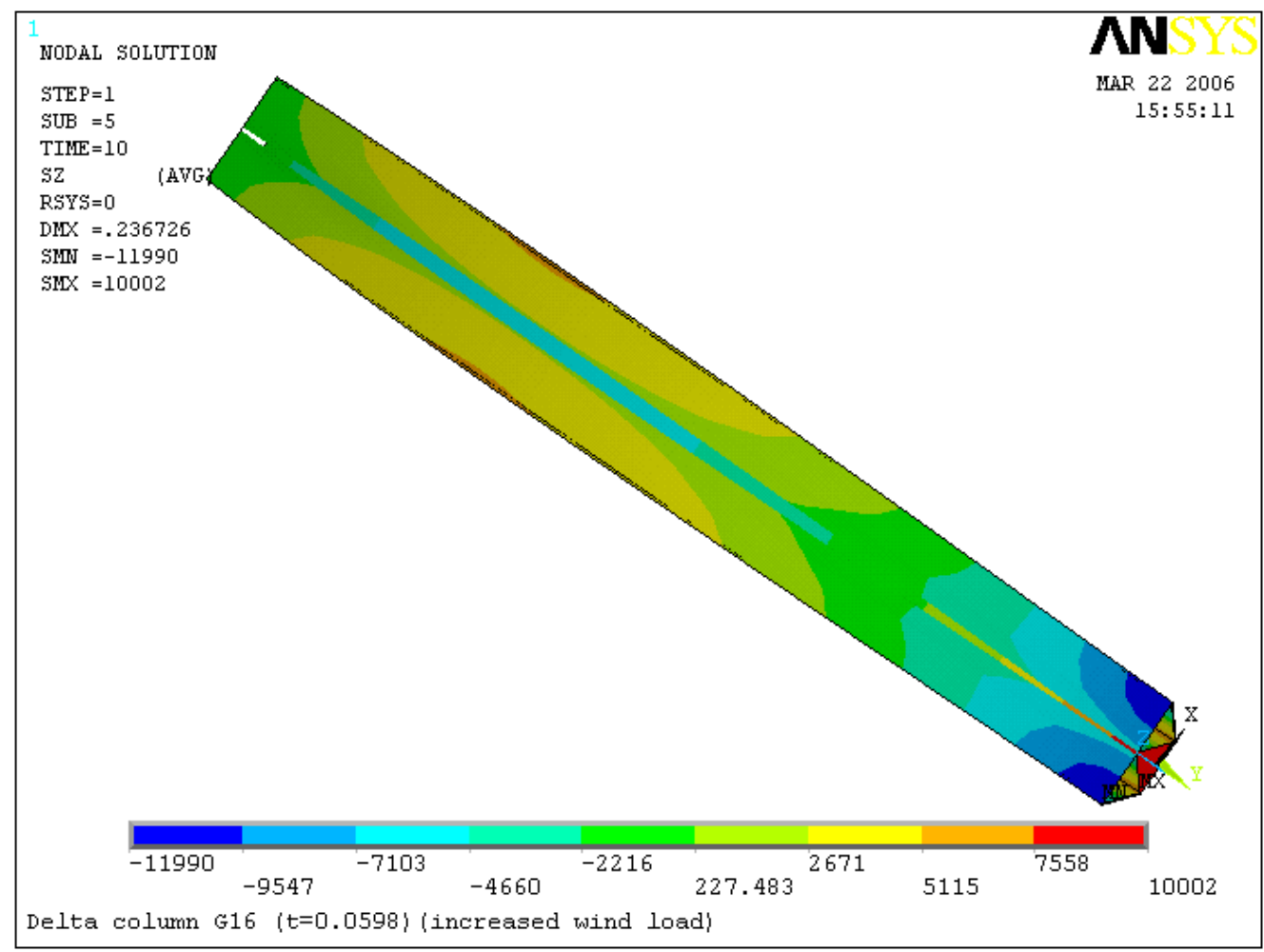

Figure 5.18 Stresses in the back side of the delta-shape column with 16 Gage (unit: psi)

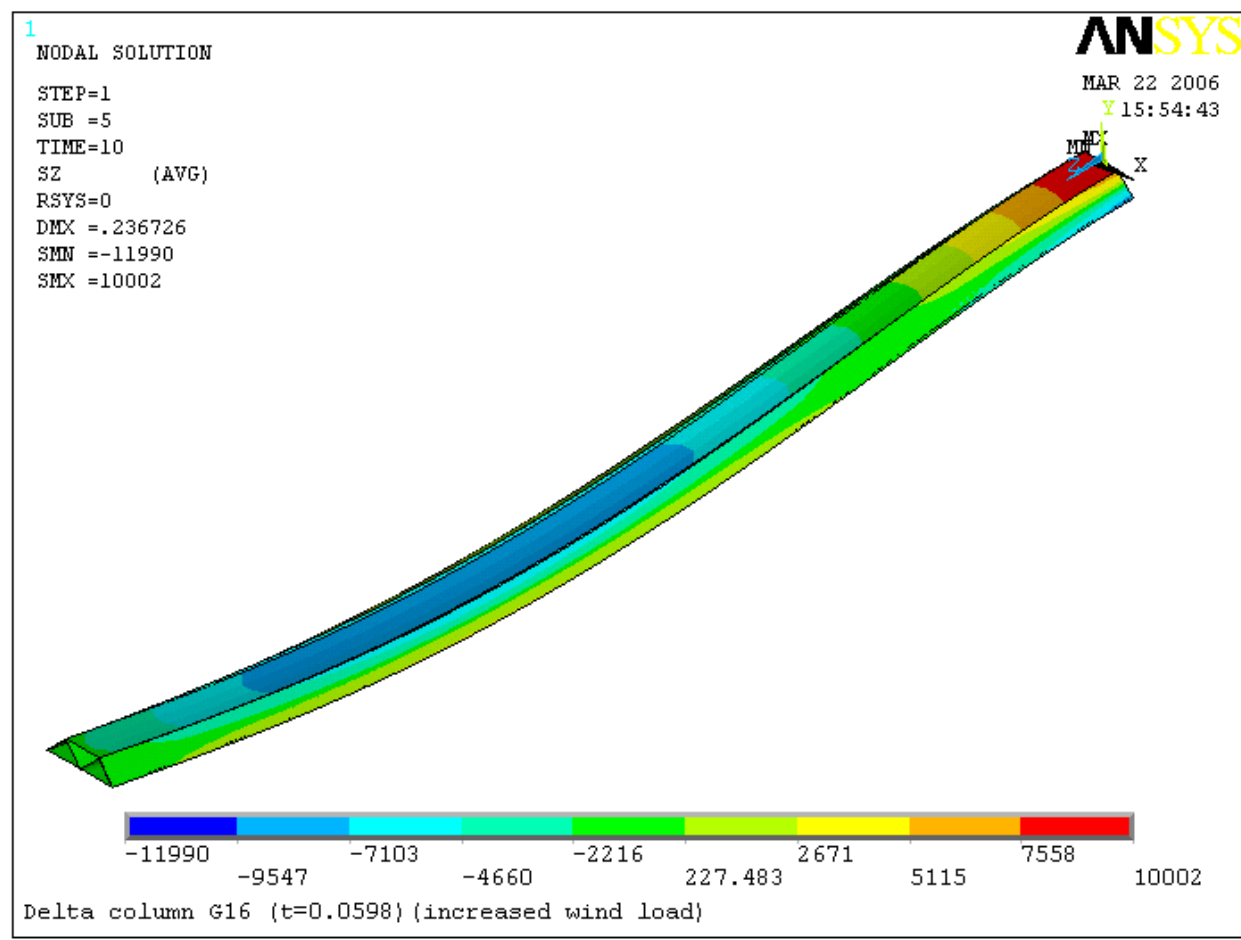

Figure 5.19 Stresses in the front side of the delta-shape column with 16 Gage (unit: psi) 


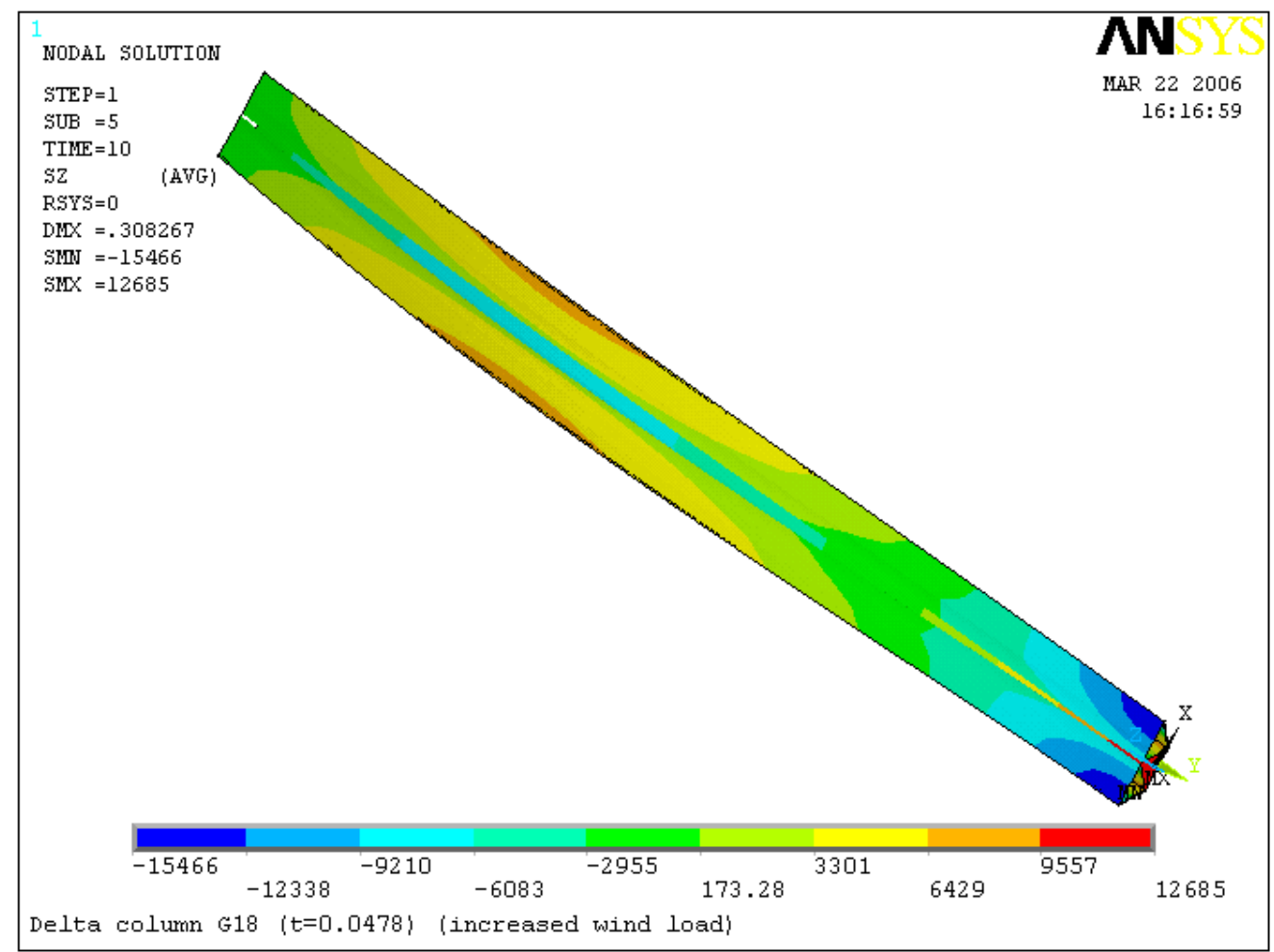

Figure 5.20 Stresses in the back side of the delta-shape column with 18 Gage (unit: psi)

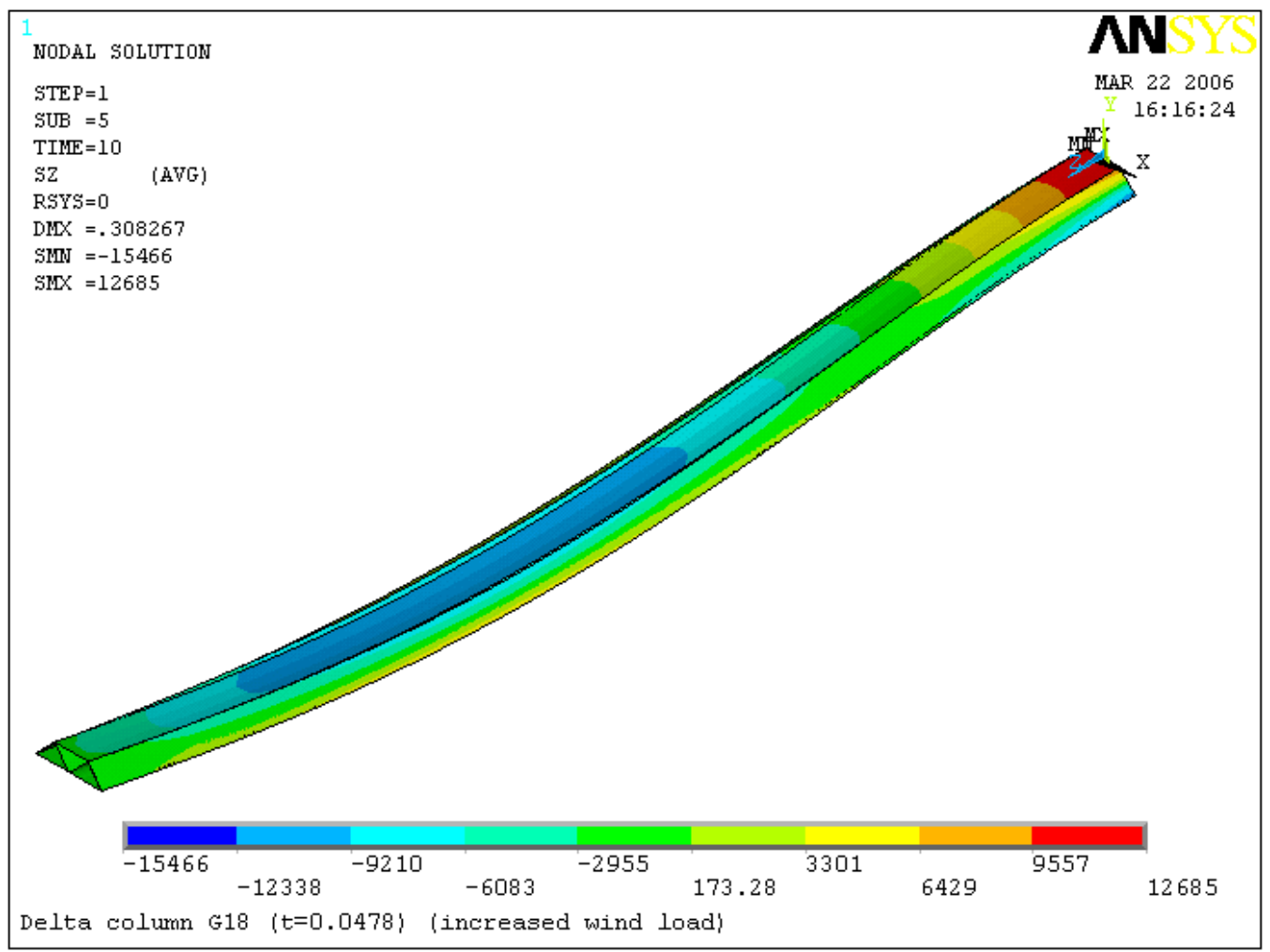

Figure 5.21 Stresses in the front side of the delta-shape column with 18 Gage (unit: psi) 


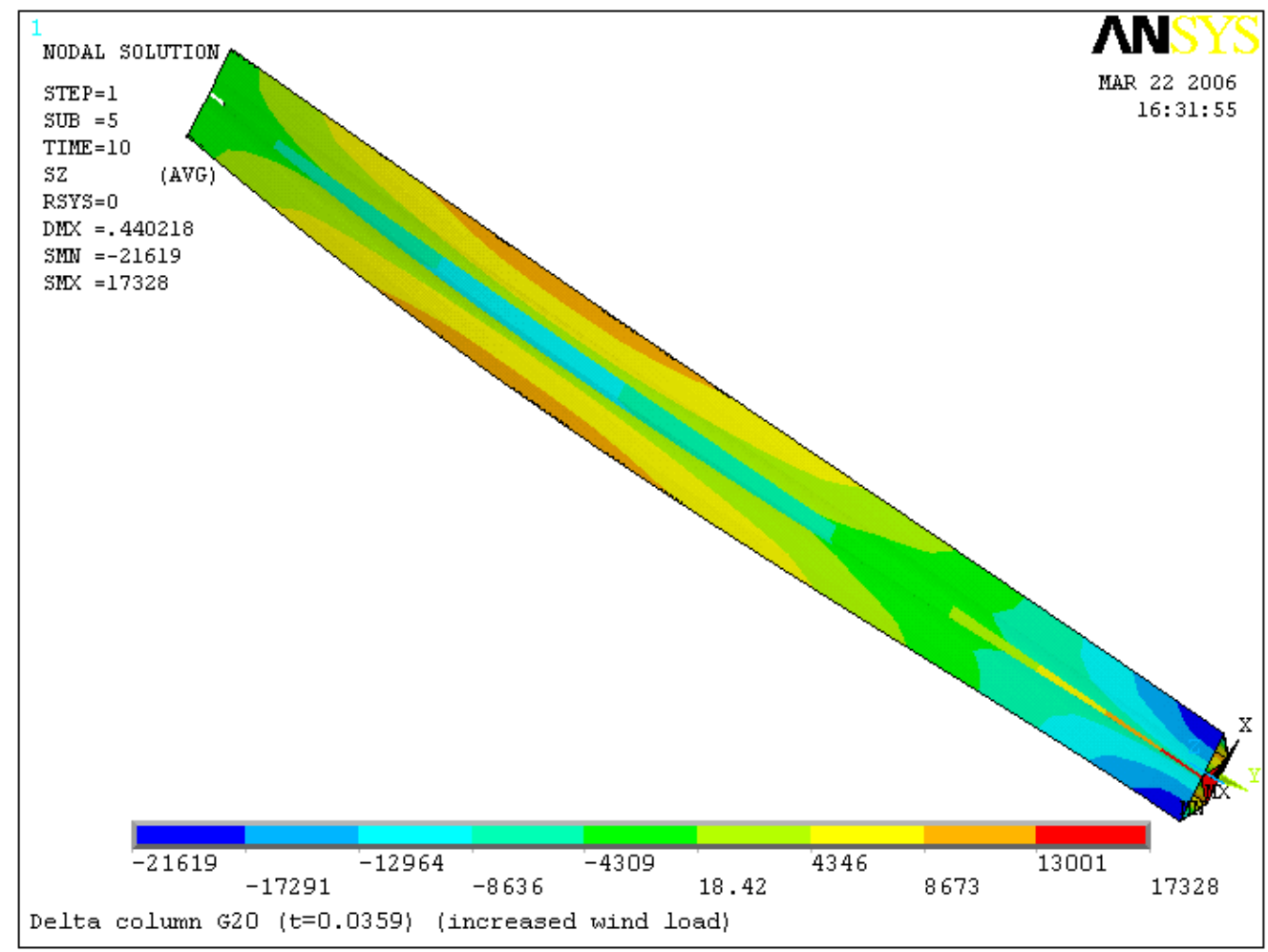

Figure 5.22 Stresses in the back side of the delta-shape column with 20 Gage (unit: psi)

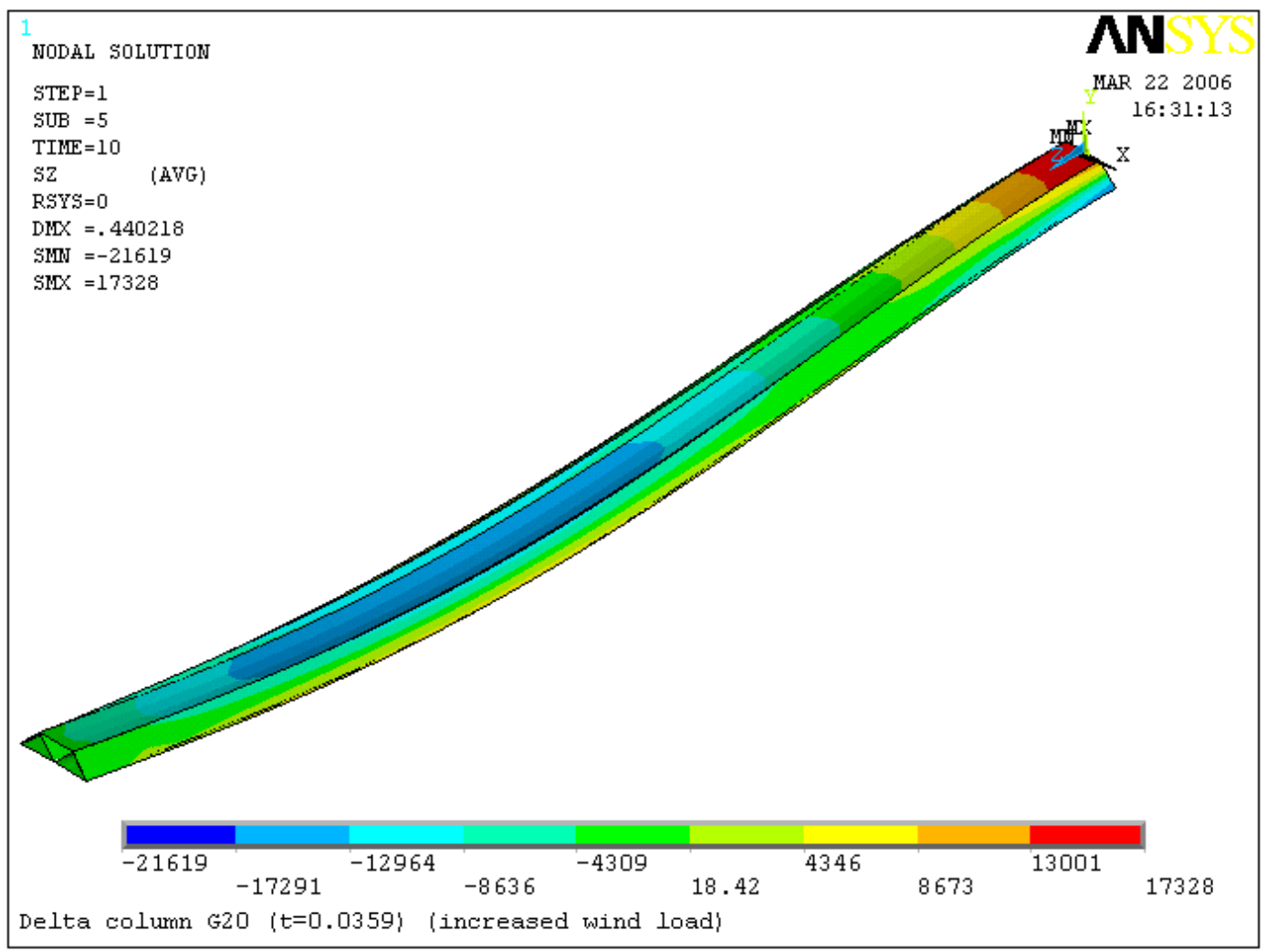

Figure 5.23 Stresses in the front side of the delta-shape column with 20 Gage (unit: psi) 
The maximum longitudinal stress of the Delta-shape columns occurred at the bottom of the column. The stress at the mid-height of the column, the larger deformation location, was also relative high. Tensile was not observed in all the studied Delta-shape columns under load Case 1, which was the same as the C-shape columns. As the thickness of the steel decreased, the stresses in the columns increased. For example, the maximum stresses of the Delta-shape columns increased from 2,401 psi to 4,140 psi as the steel thickness changed from 16 to 20 gages under load Case 1. The stresses in the columns under load Case 2 exhibited the same trends.

\subsection{Load Capability of the Delta-shape Column}

The load capabilities of the Delta-shape columns were determined based on the factored load combinations. Wind load (W) equals 0.136 psi in the load Case 1 , and increases to 1.399 psi in load Case 2, which was described in Section 2.3.2.

\subsubsection{Load Capability of the Delta-shape Column under the load Case 1}

\subsubsection{Vertical load capability of the Delta-shape column}

Vertical load capability of the Delta-shape column can be determined from combination (2):

$1.2 \mathrm{D}+1.6 \mathrm{R}+0.8 \mathrm{~W}$

Table 5.2 Vertical load capability (Rain load) of the Delta-shape column

\begin{tabular}{cccc}
\hline \multirow{2}{*}{$\begin{array}{c}\text { Steel } \\
\text { thickness }\end{array}$} & $\mathbf{R}$ (psi) & $\begin{array}{c}\text { Maximum positive } \\
\text { stress (Tension) }\end{array}$ & $\begin{array}{c}\text { Maximum negative stress } \\
\text { (Compression) }\end{array}$ \\
\cline { 3 - 4 } 16 Gage & 218.2 & ----- & $\mathbf{2 8 . 0 3 3}$ \\
\hline 18 Gage & 173.0 & ----- & $\mathbf{2 8 . 0 4 5}$ \\
\hline 20 Gage & 127.9 & ----- & $\mathbf{2 8 . 0 4 0}$ \\
\hline
\end{tabular}

Note: $1 . \phi F_{\text {steel }}=0.85 \times 33=28.05 \mathrm{ksi}$

2. Dead load and wind load are constants. 


\subsubsection{Wind load capability of the Delta-shape column}

Wind load capability of the Delta-shape column can be determined from combination (3):

$1.2 \mathrm{D}+1.6 \mathrm{~W}+0.5 \mathrm{~L}+0.5 \mathrm{~S}$

Table 5.3 Horizontal load capability (Wind load) of the Delta-shape column

\begin{tabular}{ccccc}
\hline \multirow{2}{*}{$\begin{array}{c}\text { Steel } \\
\text { thickness }\end{array}$} & W(psi) & $\begin{array}{c}\text { Maximum } \\
\text { deformation }\end{array}$ & & \multicolumn{2}{c}{ Stress in steel (ksi) } \\
\cline { 4 - 5 } (inches) & $\begin{array}{c}\text { Maximum positive } \\
\text { stress (Tension) }\end{array}$ & $\begin{array}{c}\text { Maximum negative } \\
\text { stress (Compression) }\end{array}$ \\
\hline 16 Gage & 2.21 & 0.597 & $\mathbf{2 8 . 0 3 9}$ & 27.506 \\
\hline 18 Gage & 1.72 & 0.606 & 27.497 & $\mathbf{2 7 . 9 4 8}$ \\
\hline 20 Gage & 1.21 & 0.610 & 26.008 & $\mathbf{2 7 . 9 5 6}$ \\
\hline
\end{tabular}

Note: $1 . \phi F_{\text {steel }}=0.85 \times 33=28.05 \mathrm{ksi}$

2. Dead load, live load and snow load are constants.

\subsubsection{Deflection capability of the Delta-shape column}

Deflection capability of the Delta-shape column can be determined from combination:

$\mathrm{D}+\mathrm{W}+\mathrm{L}+\mathrm{S}$ (or $\mathrm{Lr})$

Table 5.4 Deformation vs. wind load (W) of the Delta-shape column

\begin{tabular}{|c|c|c|c|c|}
\hline \multirow{2}{*}{$\begin{array}{c}\text { Steel } \\
\text { thickness }\end{array}$} & \multirow[b]{2}{*}{ W(psi) } & \multirow{2}{*}{$\begin{array}{l}\text { Maximum } \\
\text { deformation } \\
\text { (inches) }\end{array}$} & \multicolumn{2}{|c|}{ Stress in steel(ksi) } \\
\hline & & & $\begin{array}{l}\text { Maximum positive } \\
\text { stress (Tension) }\end{array}$ & $\begin{array}{l}\text { Maximum negative } \\
\text { stress (Compression) }\end{array}$ \\
\hline 16 Gage & 1.77 & 0.30 & 13.015 & 14.808 \\
\hline 18 Gage & 1.36 & 0.299 & 12.284 & 15.084 \\
\hline 20 Gage & 0.96 & 0.300 & 11.098 & 15.475 \\
\hline
\end{tabular}

\subsubsection{Vertical Load Capability of the Delta-shape Column under the load Case 2}

Vertical load capability of the Delta-shape column can be determined from combination (2): $1.2 \mathrm{D}+1.6 \mathrm{R}+0.8 \mathrm{~W}$ 
Table 5.5 Vertical load capability (Rain load) of the Delta-shape column

\begin{tabular}{cccc}
\hline \multirow{2}{*}{$\begin{array}{c}\text { Steel } \\
\text { thickness }\end{array}$} & $\mathbf{R}(\mathbf{p s i})$ & $\begin{array}{c}\text { Maximum positive } \\
\text { stress (Tension) }\end{array}$ & $\begin{array}{c}\text { Maximum negative stress } \\
\text { (Compression) }\end{array}$ \\
\hline 16 Gage & 157.4 & ----- & $\mathbf{2 8 . 0 4 4}$ \\
\hline 18 Gage & 109.7 & ---- & $\mathbf{2 8 . 0 5 0}$ \\
\hline Note: $1 . \phi F_{\text {steel }}=0.85 \times 33=28.05 k s i$, 2. Dead load and wind load are constants.
\end{tabular}





\section{CHAPTER 6}

MODELING AND ANALYSIS OF THE ORIGINAL-SHAPE COLUMN

6.1 Description of Input and Modeling of the Original Column without foam

6.1.1 Dimensions and modeling of the original column without foam

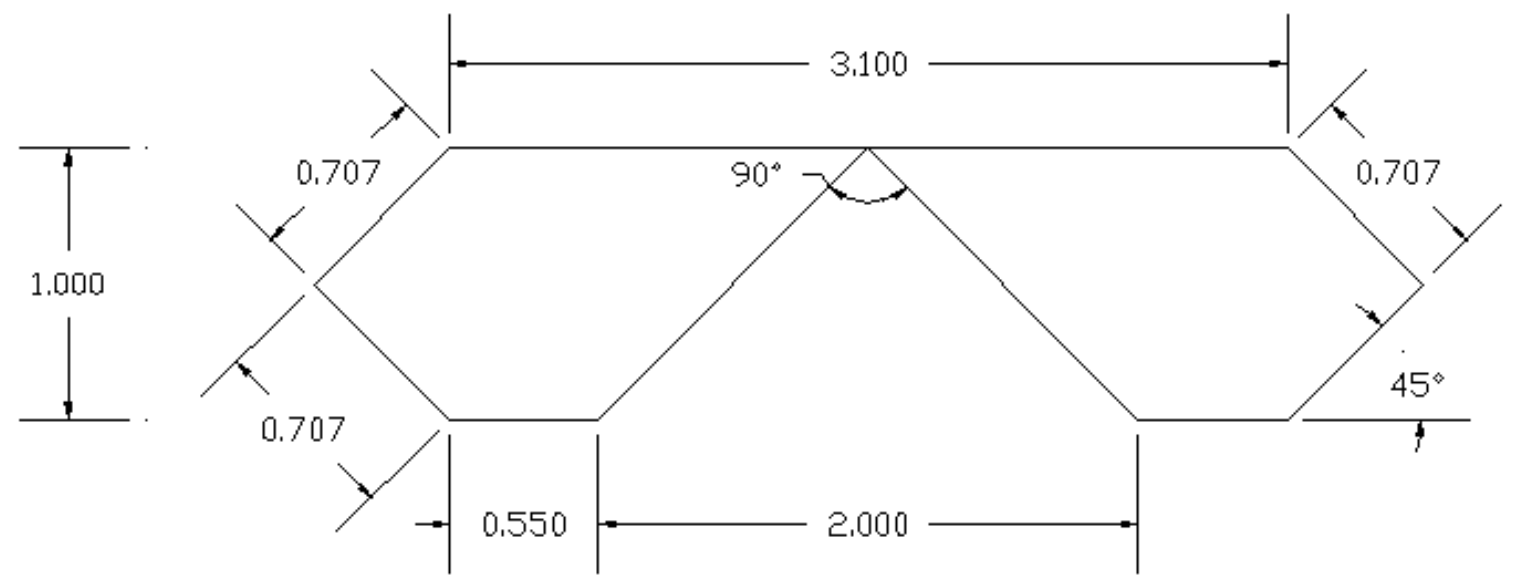

Figure 6.1 Cross-section of the original-shape column (unit: inches)

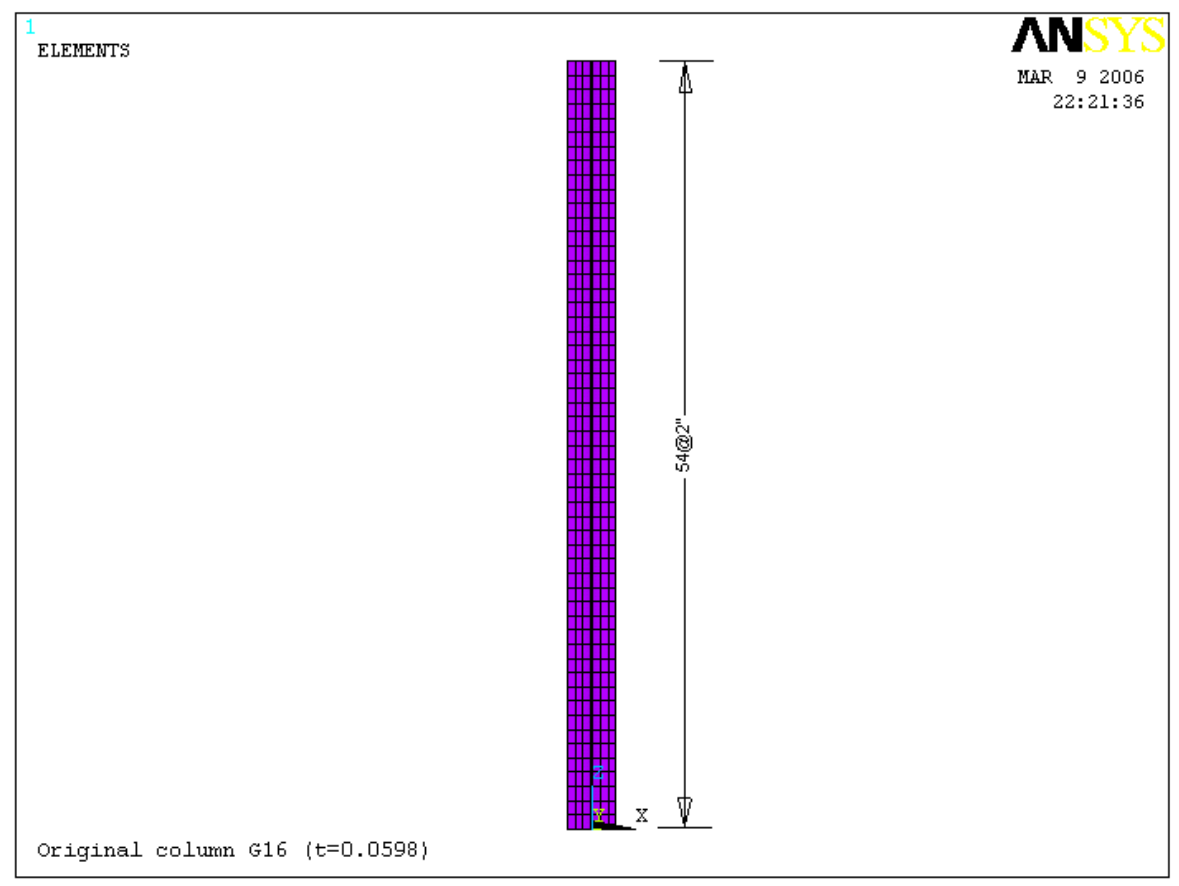

Figure 6.2 Elevation of the original column 


\subsubsection{Finite element model of the original column}

Shell elements (Shell181) were used to model the Original. Figure 6.3 shows the threedimensional view of the Original column model. The model was restrained with pin supports at the top of the column and fix supports at the bottom except the rotation about $\mathrm{X}$ direction, as shown in Figure. 6.4.

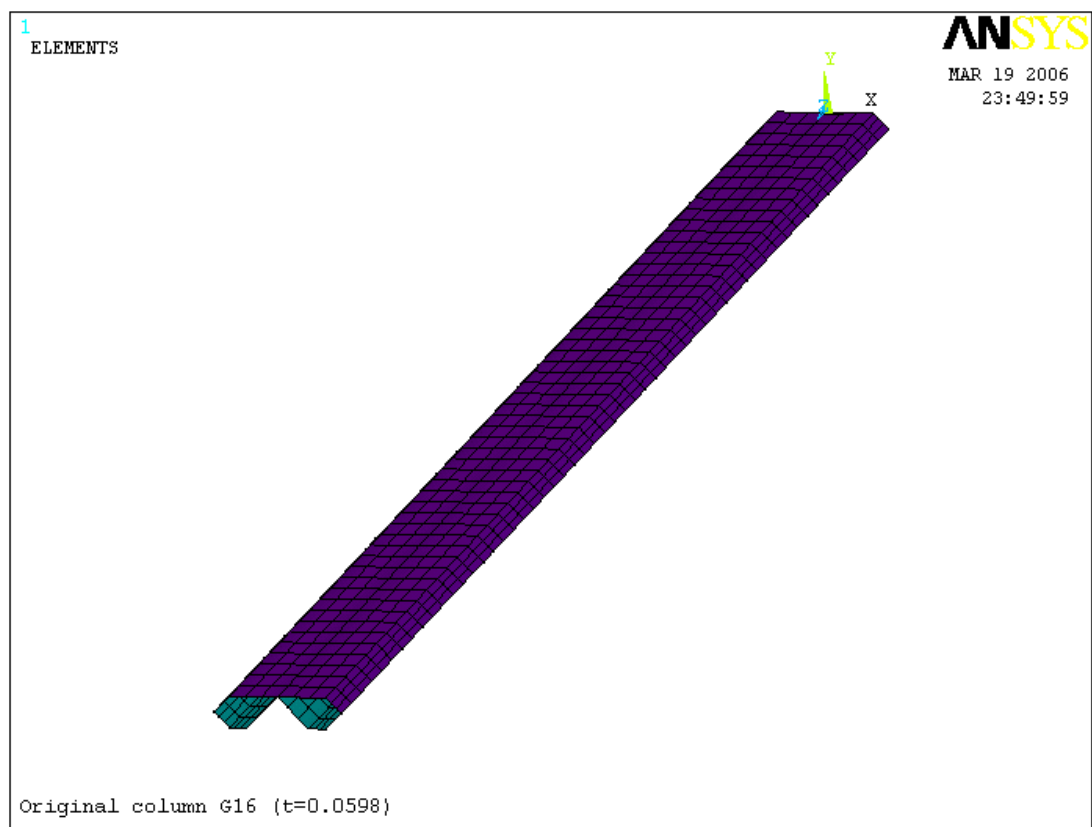

Figure 6.3 3-D original column model

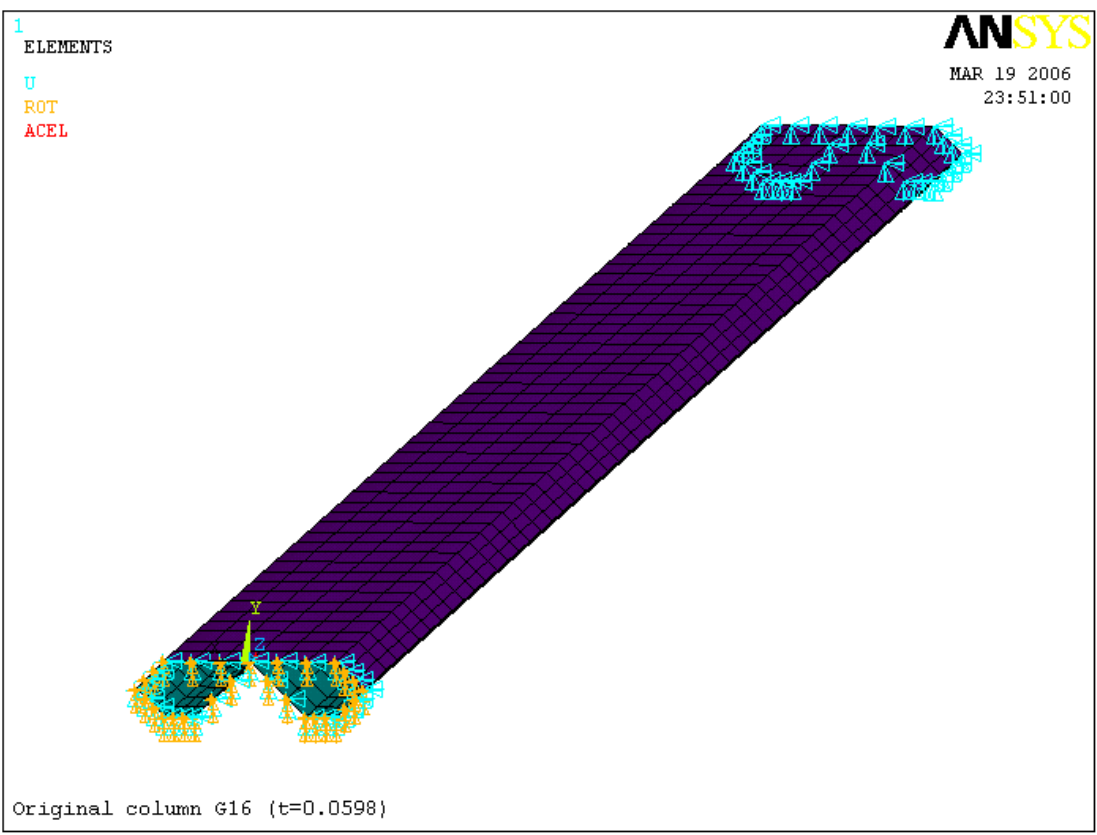

Figure 6.4 Original column model with end restraints 


\subsubsection{Loads}

Table 6.1 Applied load of the original columns

\begin{tabular}{ccccc}
\hline \multirow{2}{*}{$\begin{array}{c}\text { Steel } \\
\text { thickness }\end{array}$} & $\begin{array}{c}\text { Dead load } \\
\text { ( lbs) }\end{array}$ & $\begin{array}{c}\text { Live load } \\
\text { (lb/in) }\end{array}$ & \multicolumn{2}{c}{ Wind load (psi) } \\
\cline { 4 - 5 } 16 Gage & 23.730 & 147.285 & Case 1 & Case 2 \\
\hline 18 Gage & 18.968 & 147.285 & 0.136 & 1.579 \\
\hline 20 Gage & 14.246 & 147.285 & 0.136 & ---- \\
\hline
\end{tabular}

Note:

1. Case 1 denotes columns carry the wind load based on column area only;

2. Case 2 denotes columns carry the wind load based on 36 in wide tributary area.

Figure 6.5 is an example of the Delta-shape column with loads. It was assumed that the column would resist wind load on its front side.

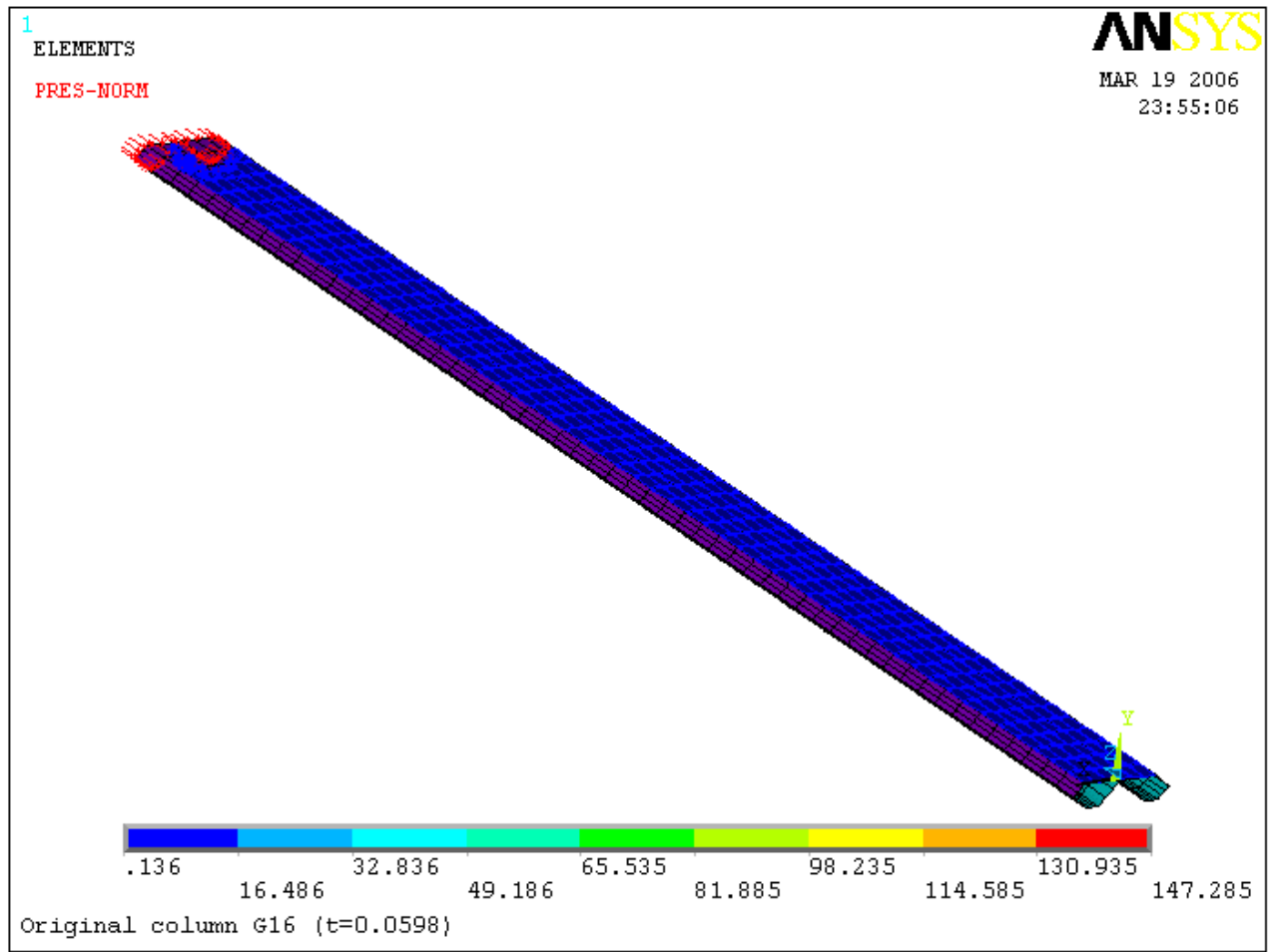

Figure 6.5 Loads on the original column

(Positive values denote the pressure act into the areas) 


\subsection{Analytical Results of the Original Column without Foam}

\subsubsection{Deformation}

Figures 6.6 through 6.8 show the deformation of the original columns with Gage 16, 18 and

Gage 20 under the load Case 1. Figures 6.9 show the deformation of the original column with Gage 16 under the load Case 2.

\subsubsection{Deformation of original column under the load Case 1}

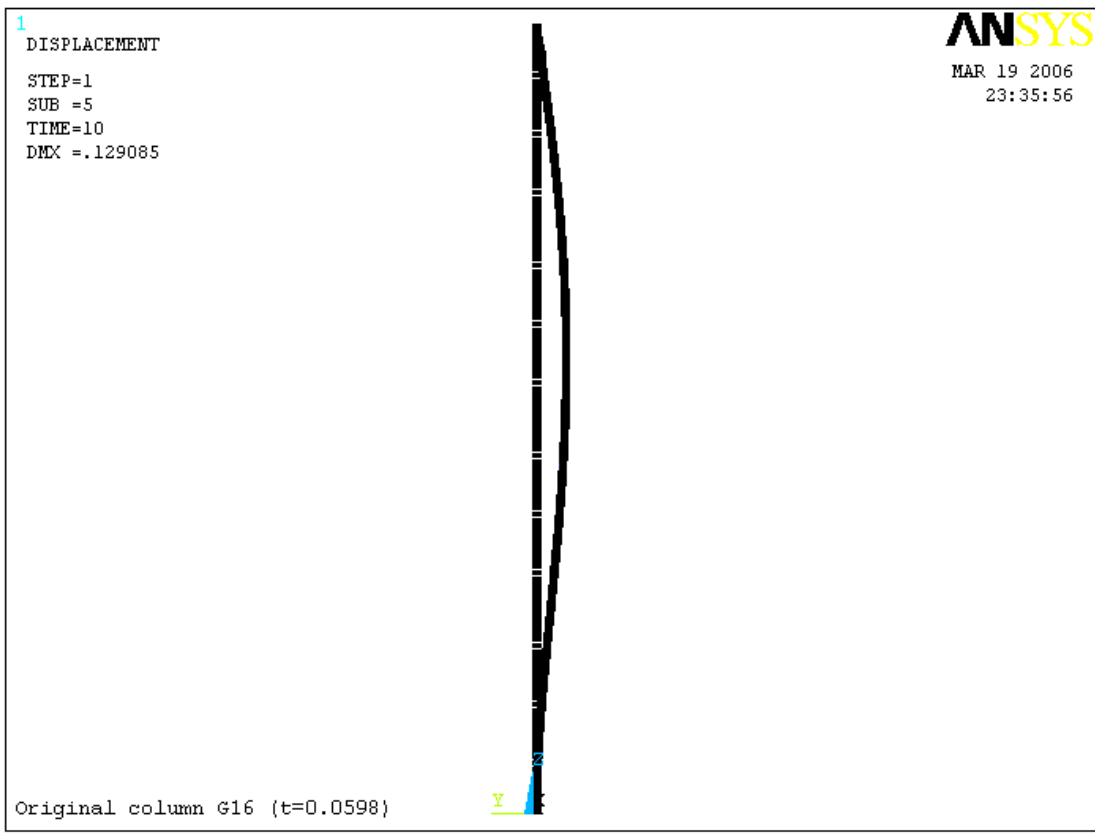

Figure 6.6 Deformation of the original column with 16 Gage (unit: inches) 


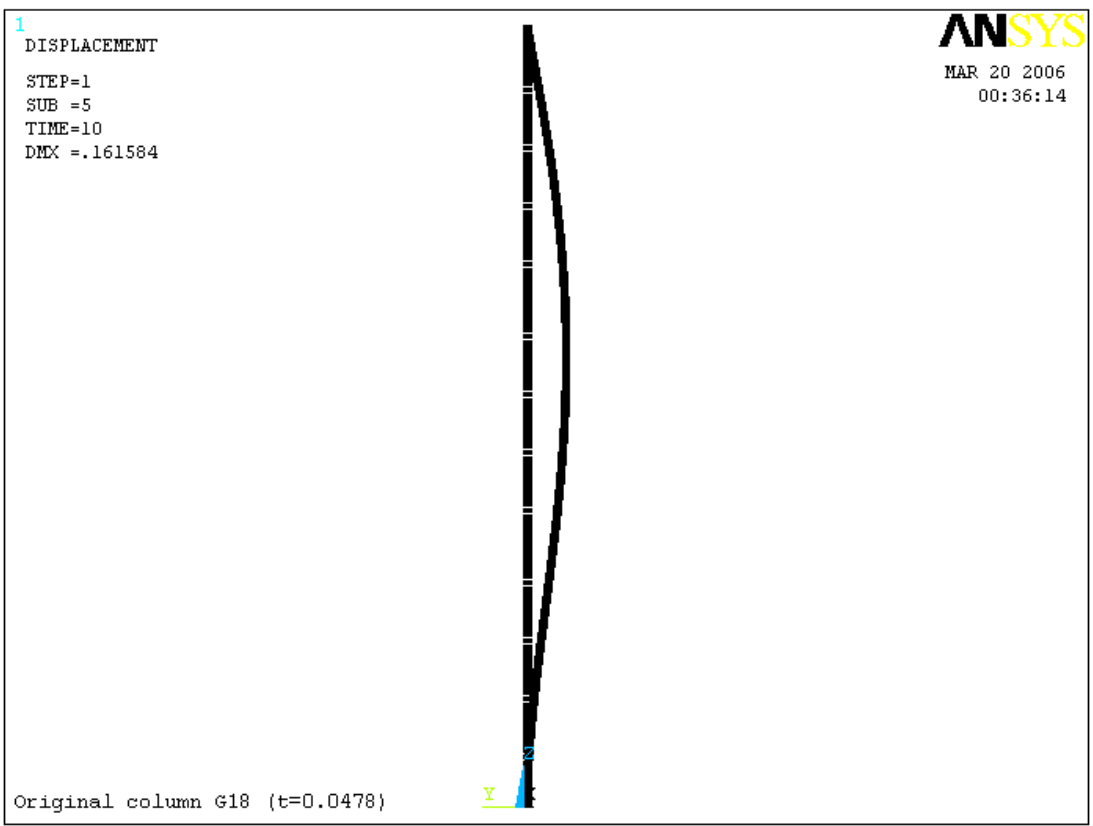

Figure 6.7 Deformation of the original column with 18 Gage (unit: inches)

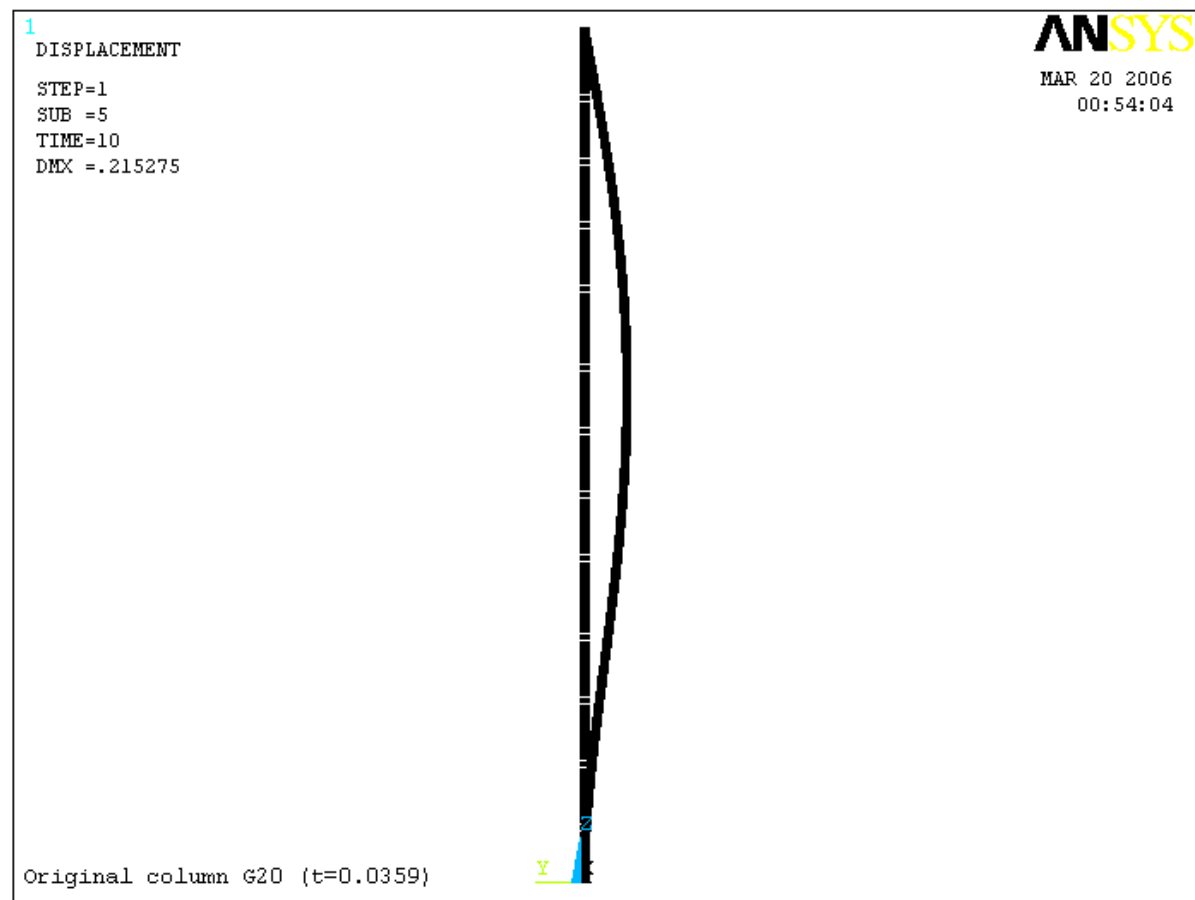

Figure 6.8 Deformation of the original column with 20 Gage (unit: inches) 


\subsubsection{Deformation of original column under the load Case 2}

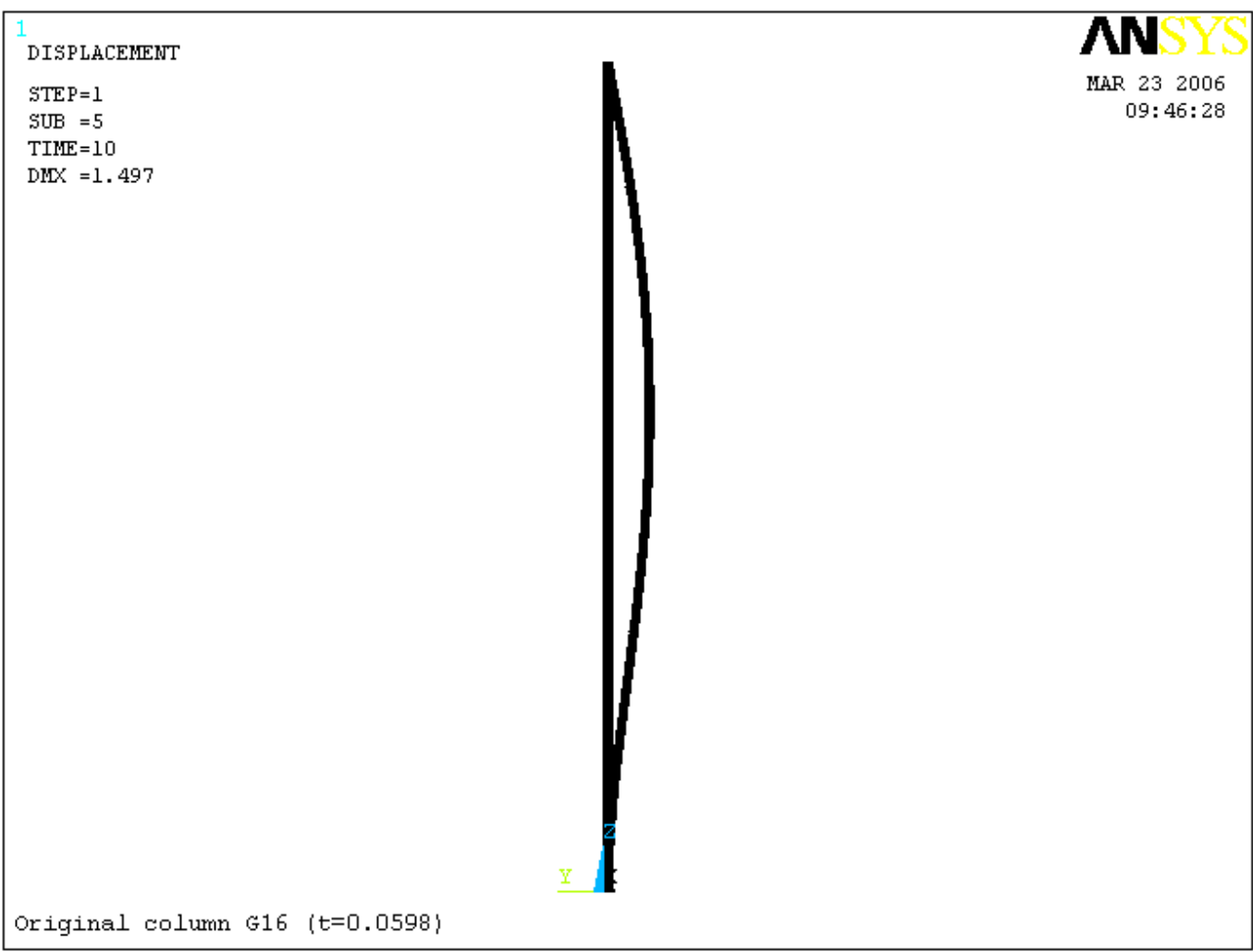

Figure 6.9 Deformation of the original column with 16 Gage (unit: inches)

No twisting was observing in the deformation of all original columns, which was the same as the Delta-columns. The maximum deformations of all original columns occurred at about 46" from the top surface. The maximum deformation of the original columns increased as the thickness of the steel facing decreased. For example, the maximum deformation of the original columns increased from 0.129 in. to 0.215 in. as the steel thickness changed from 16 gage to 20 gage. As far as the maximum deformations under load Case 1, all original columns can be acceptable, but the slenderness ratios of all original columns were around 284, which was greater than the limit of the code (AISC LRFD Specifications).

The lateral deformation of original columns made of 16 gage steel were very larger than the limit of L/360 when columns were subjected to wind load based on 36 in wide tributary area. (The limitation of Delta deformation is $\mathrm{L} / 360=0.3$ inch). 
Compared to the C-shape column and Delta-shape column with the same steel thickness under the same load, the maximum deformation of the original column was the largest. For example, the maximum deformation of the Delta column made of 16 gage steel was 0.0232 inch, while the maximum deformation of the original 16 gage column was 0.1291 inch under load Case 1.

\subsubsection{Stresses of the original columns}

Figures 6.10 through 6.15 show the stresses of original columns made of 16, 18 and 20 gage steel under the load Case 1. Figures 6.16 through 6.17 show the stresses of the original column with Gage16 under the load Case 2.

\subsubsection{Stresses in longitudinal direction of original column under load Case 1}

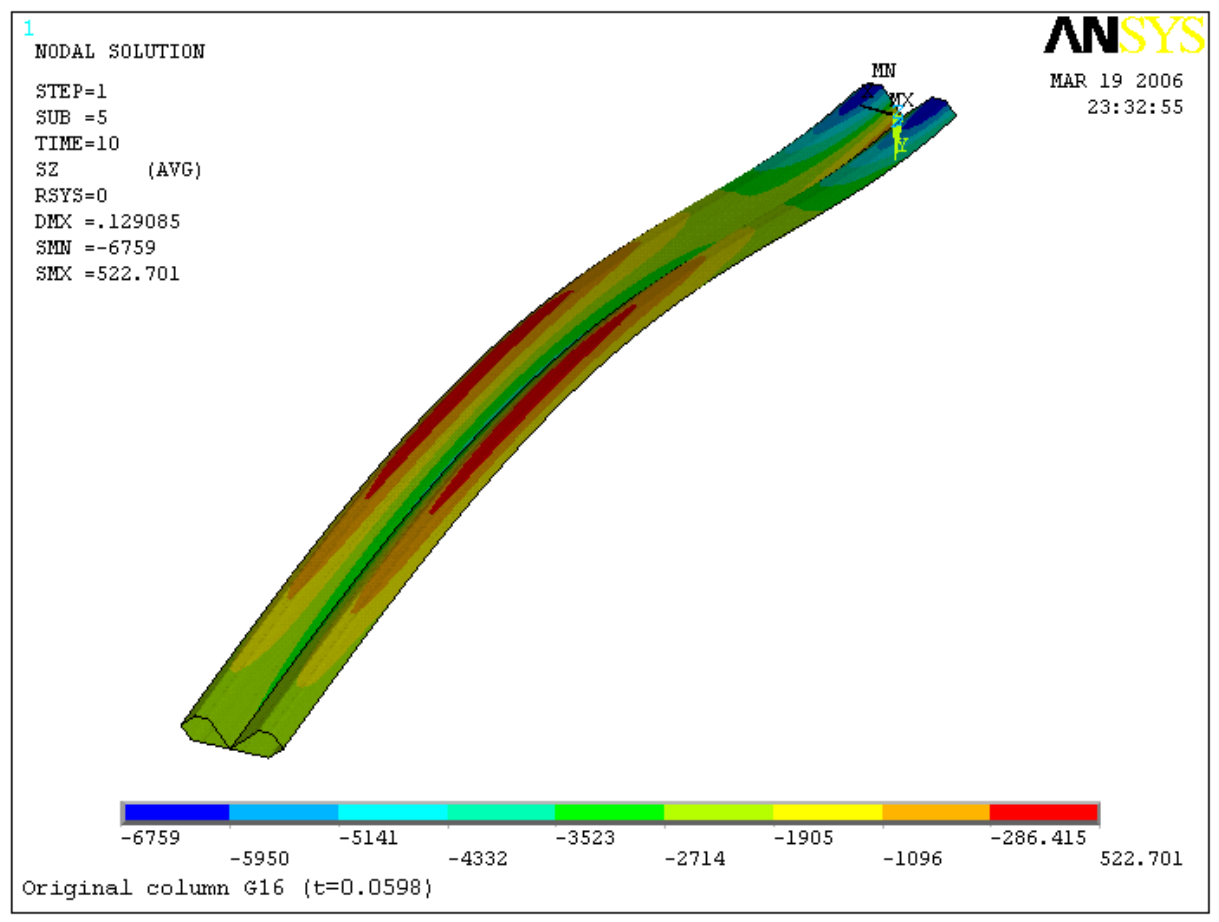

Figure 6.10 Stresses in the back side of the Original column with 16 Gage (unit: inches) 


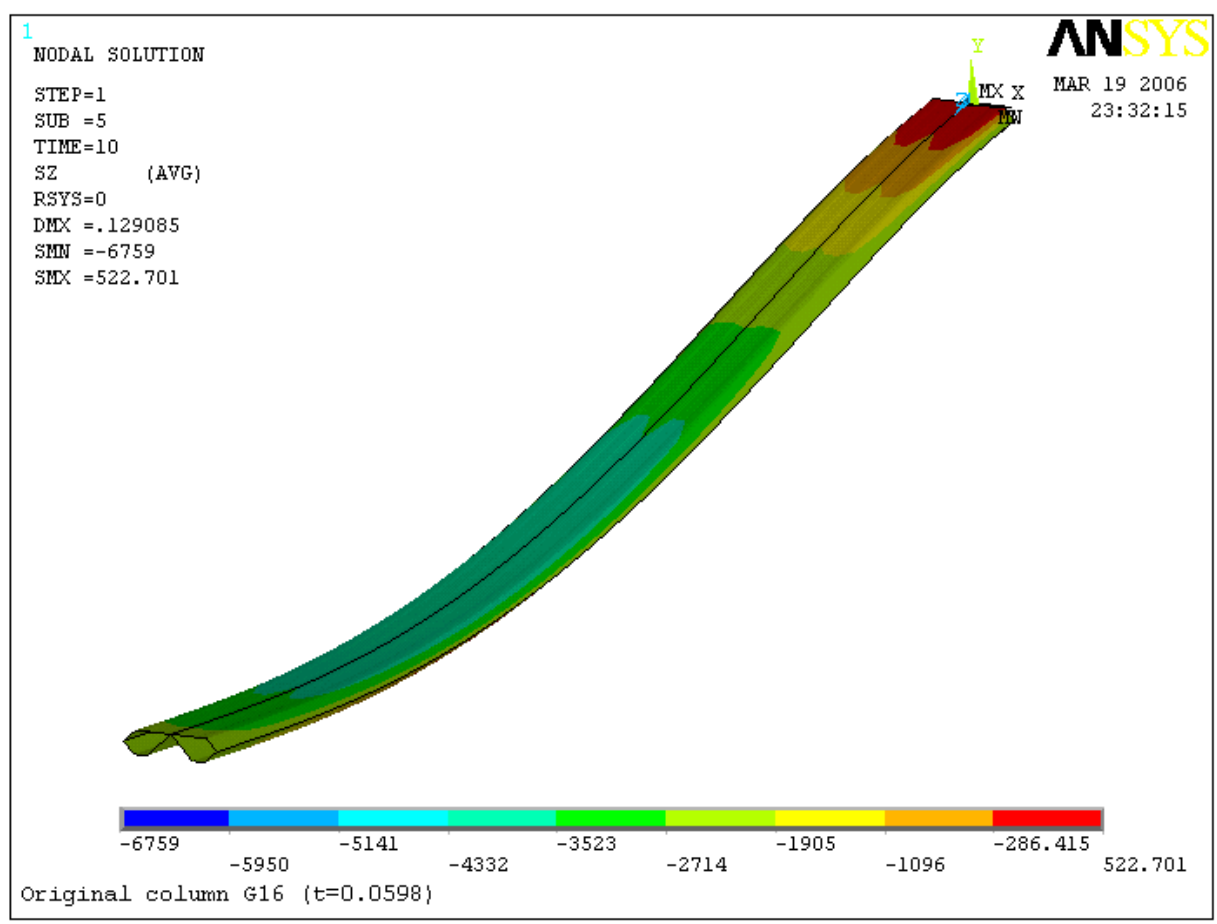

Figure 6.11 Stresses in the front side of the Original column with 16 Gage (unit: inches)

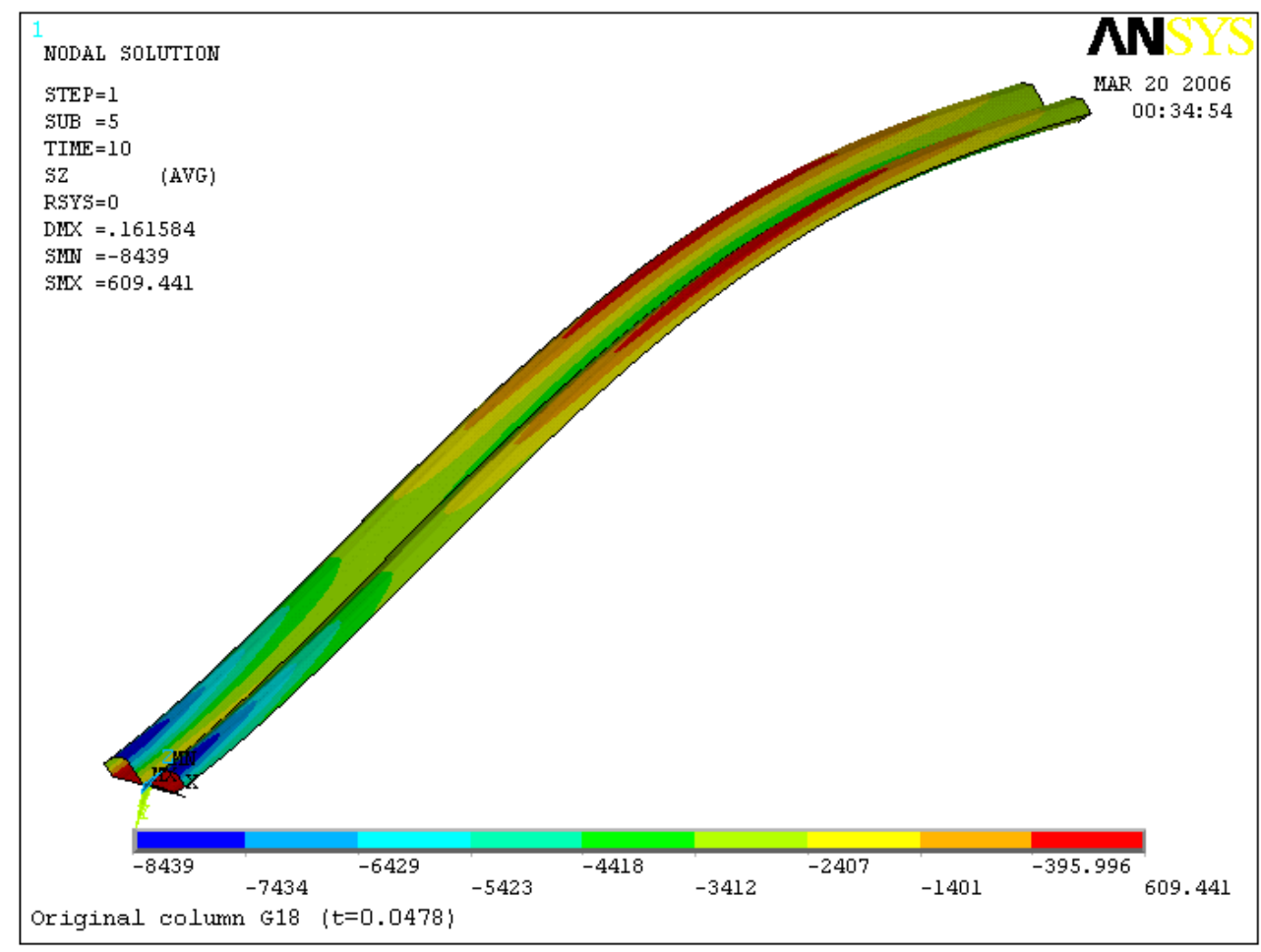

Figure 6.12 Stresses in the back side of the Original column with 18 Gage (unit: inches) 


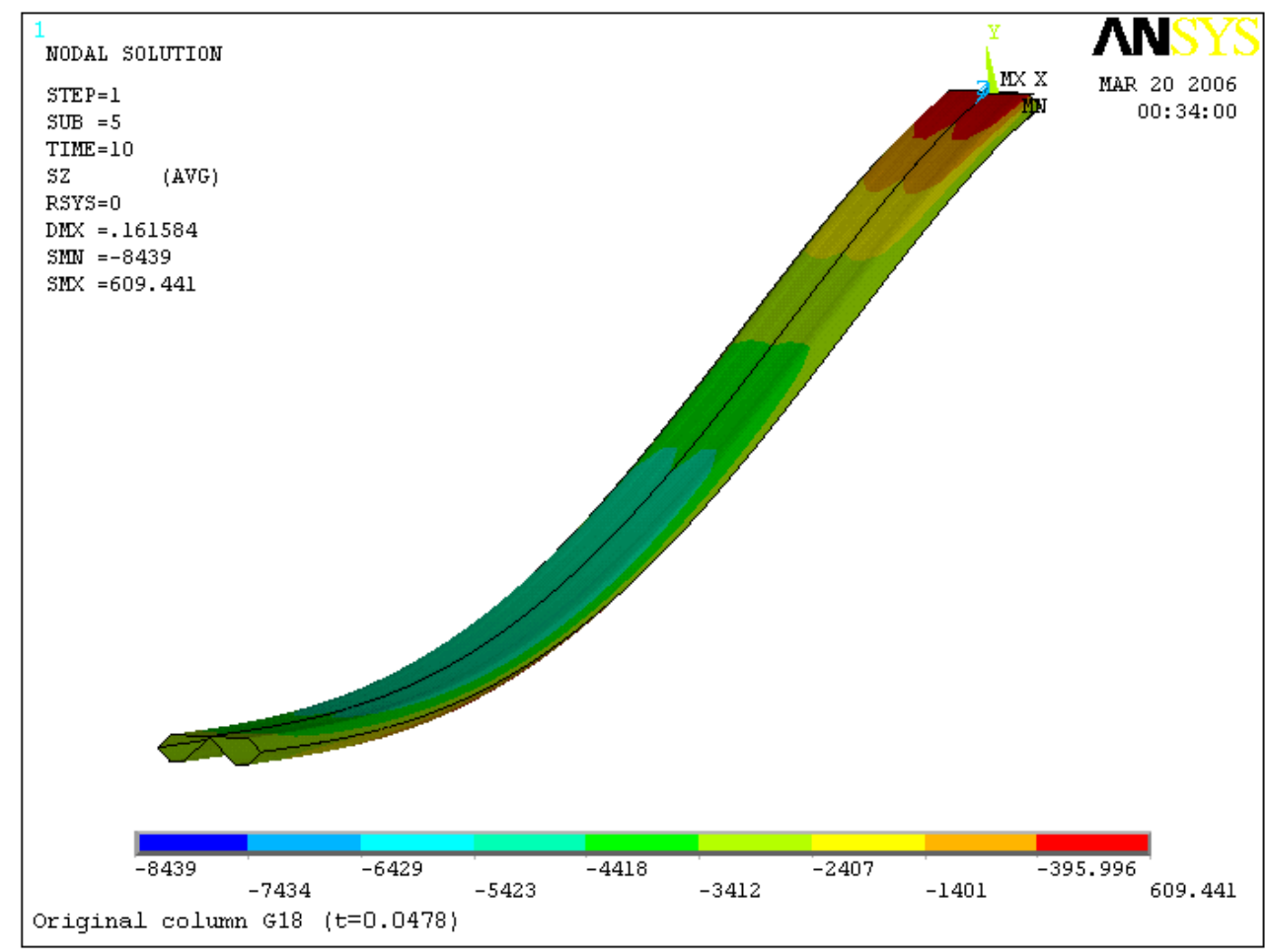

Figure 6.13 Stresses in the front side of the Original column with 18 Gage (unit: inches)

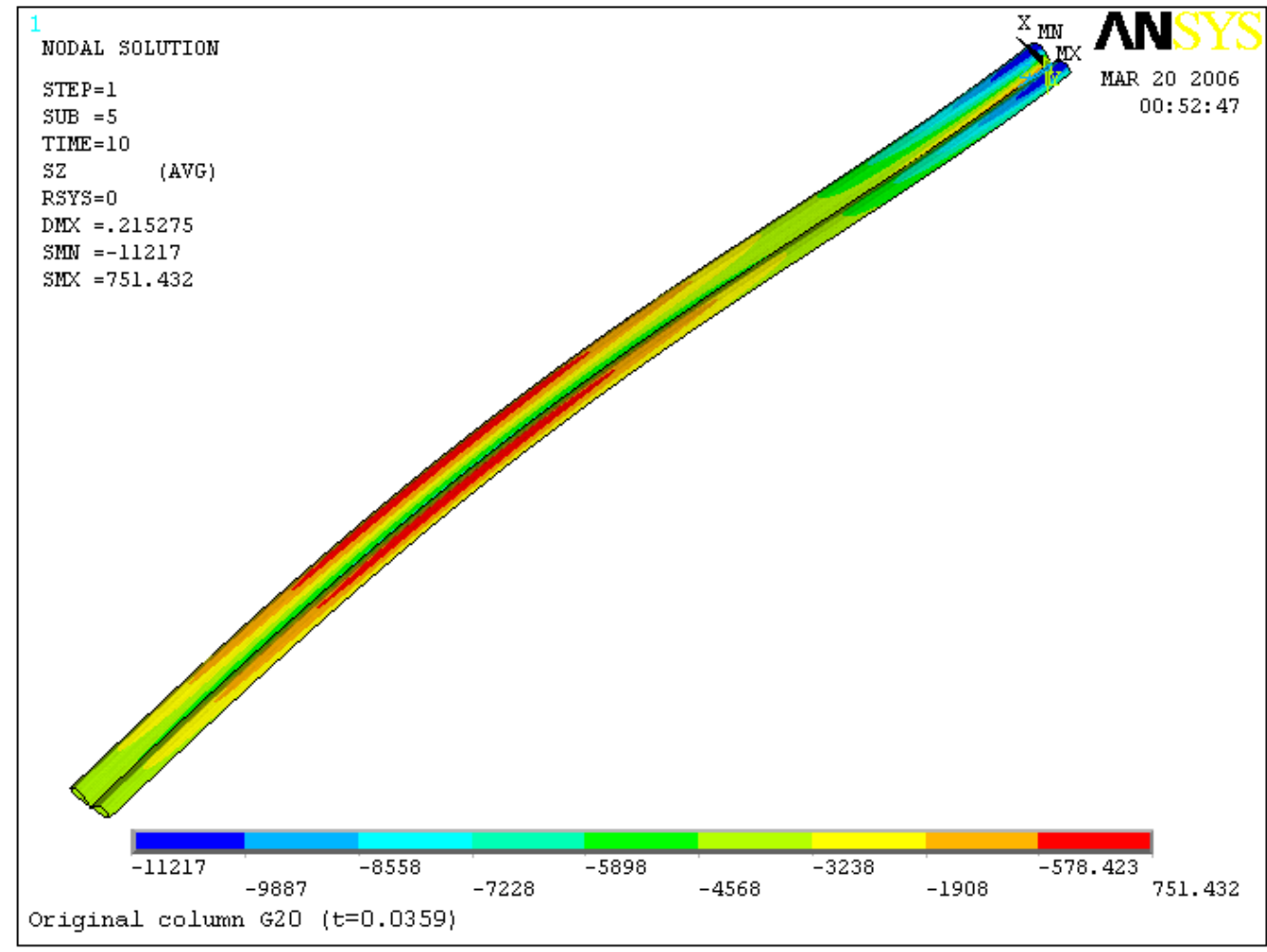

Figure 6.14 Stresses in the back side of the Original column with 20 Gage (unit: inches) 


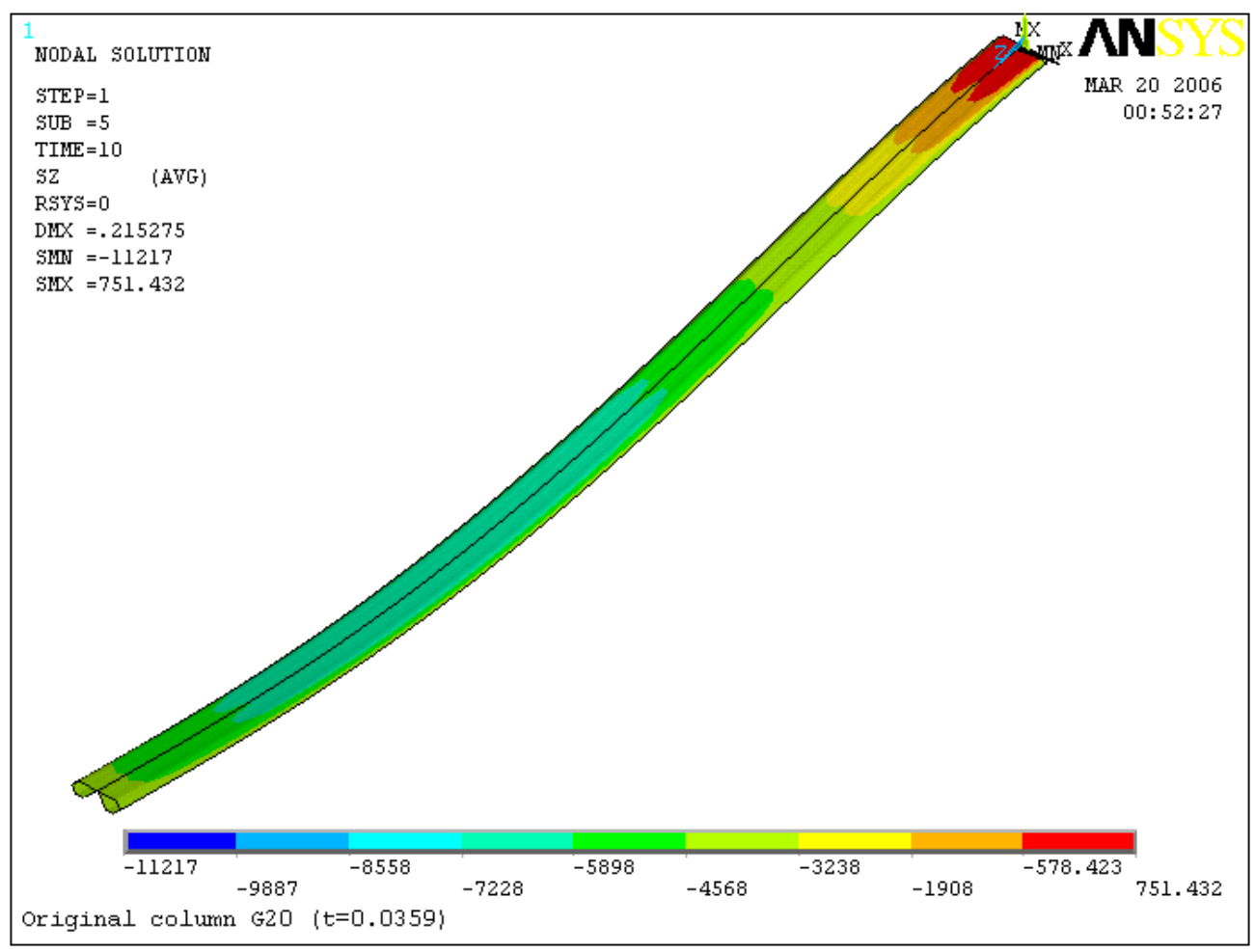

Figure 6.15 Stresses in the front side of the Original column with 20 Gage (unit: inches)

In the longitudinal direction, the maximum compressive stresses and tensile stresses of all the original columns occurred at the bottom of the columns under load Case 1 . In addition, the stresses of the columns at the upper positions were relative high. The stresses of the original columns increased as the thickness of the steel decreased. For example, the maximum stresses of the original columns increased from 6759 psi to 11217 psi as the steel thickness changed from 16 gage to 20 gage under load Case 1.

The maximum stress of the original column was larger than the stresses of the C-shape and Delta-shape columns with the same steel thickness and under the same loads. For example, the maximum stress of the Delta column made of 16 gage steel was 2401psi, while the maximum stress of the original column made of 16 gage steel was 6759 psi under load Case 1. 
6.2.2.2 Stresses in longitudinal direction of original column under load Case 2

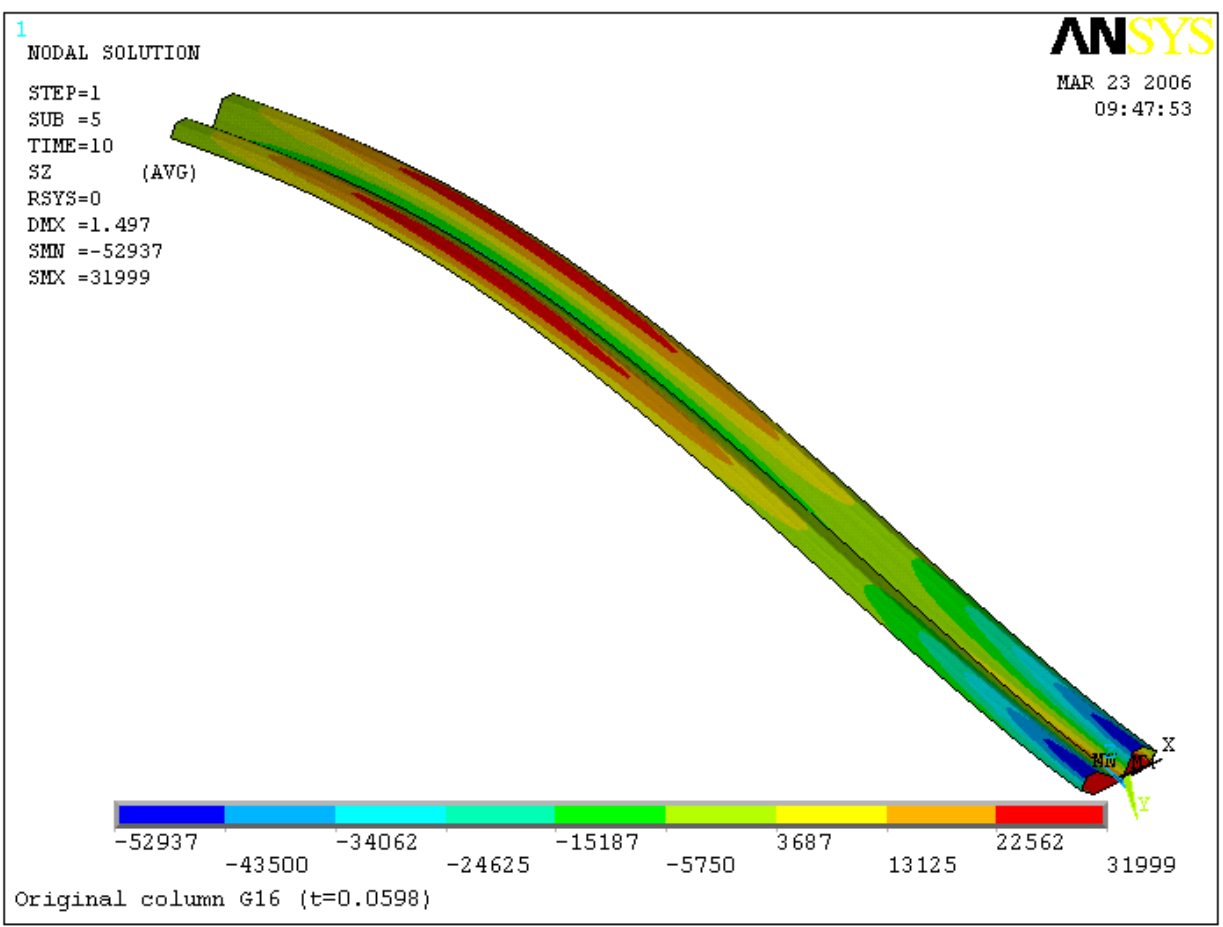

Figure 6.16 Stresses in the back side of the Original column with 16 Gage (unit: inches)

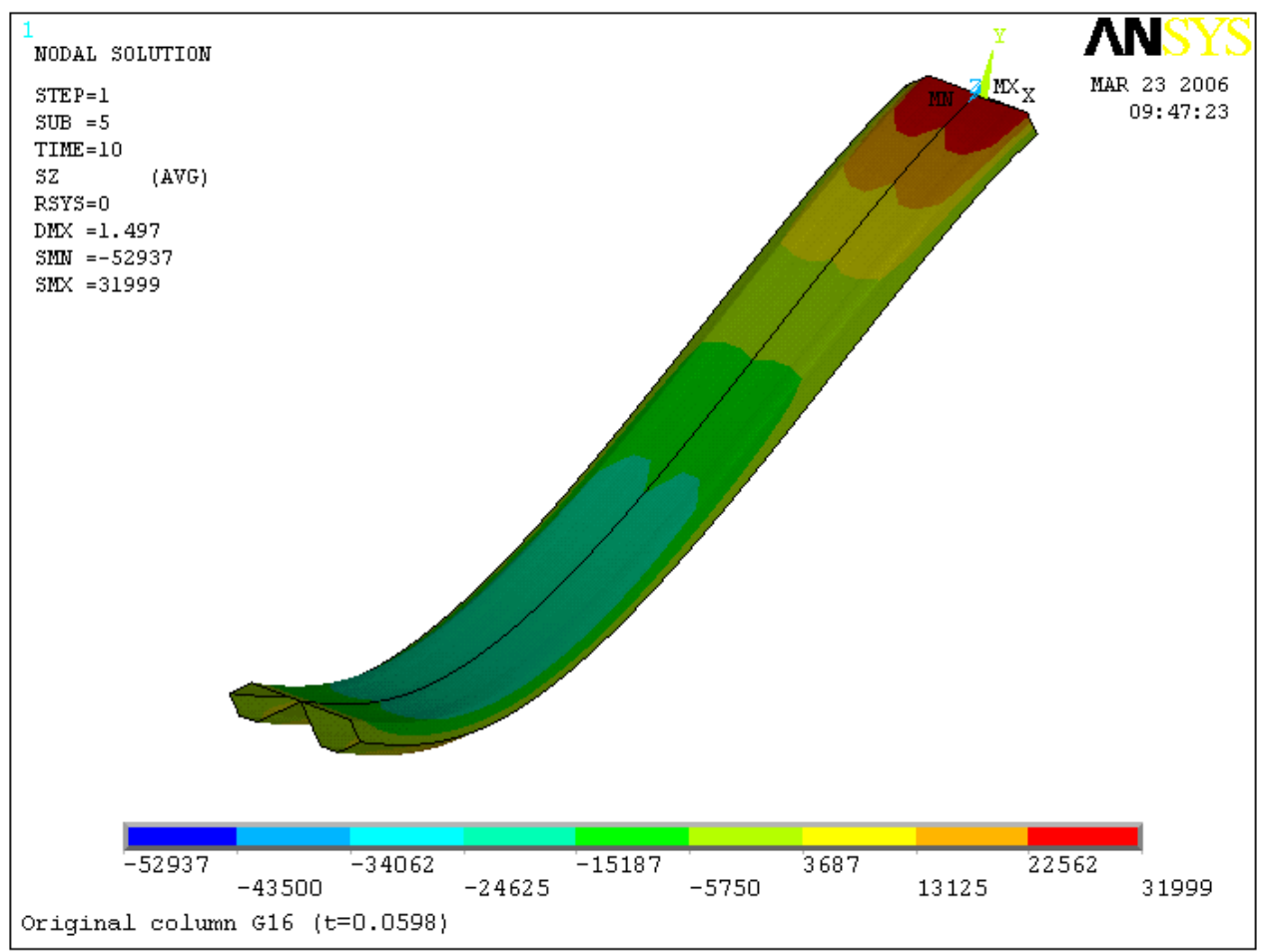

Figure 6.17 Stresses in the front side of the Original column with 16 Gage (unit: inches) 
The stresses in the columns under load Case 2 exhibited the same trends as the ones under load Case 1 . The stresses of the original column made of 16 gage steel were too large to satisfy the deformation limitation when the column subjected to wind load based on 36 in wide tributary area. Compared to the maximum stresses of the maximum stress of the original column was larger than the stresses of the C-shape and Delta-shape columns with same steel thickness under the same loads. For example, the maximum stress of the Delta column made of 16 gage steel was 2401 psi, while the maximum stress of the original column made of 16 gage steel was 6759 psi under load Case 1.

\subsection{Description of Input and Modeling of the Original Column with foam}

\subsubsection{Dimensions and modeling of the original column with foam}

The original column with foam made of 16 gage steel under Case 1 was studied.

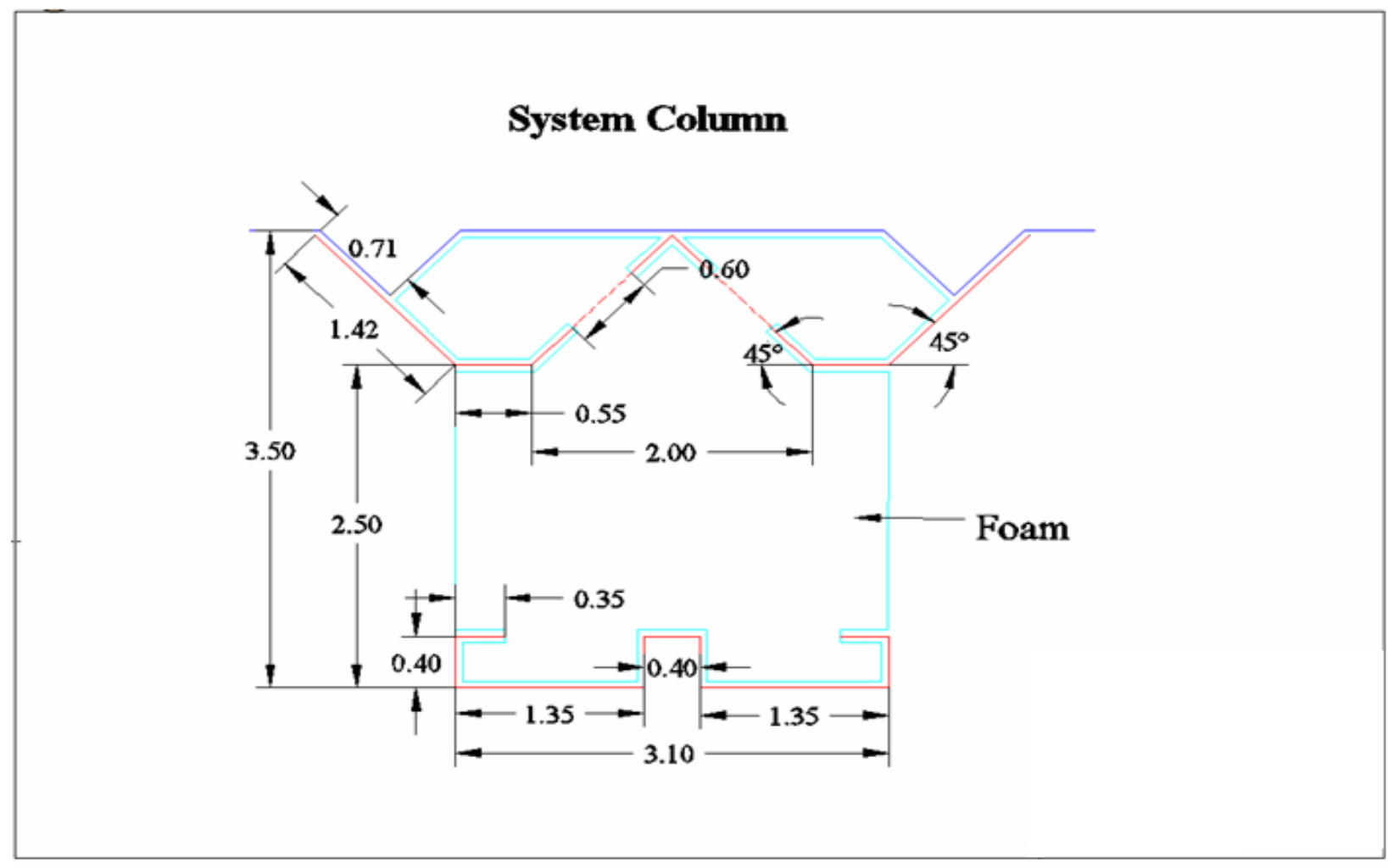

Figure 6.18 Cross-section of the original column with foam (unit: inches) 


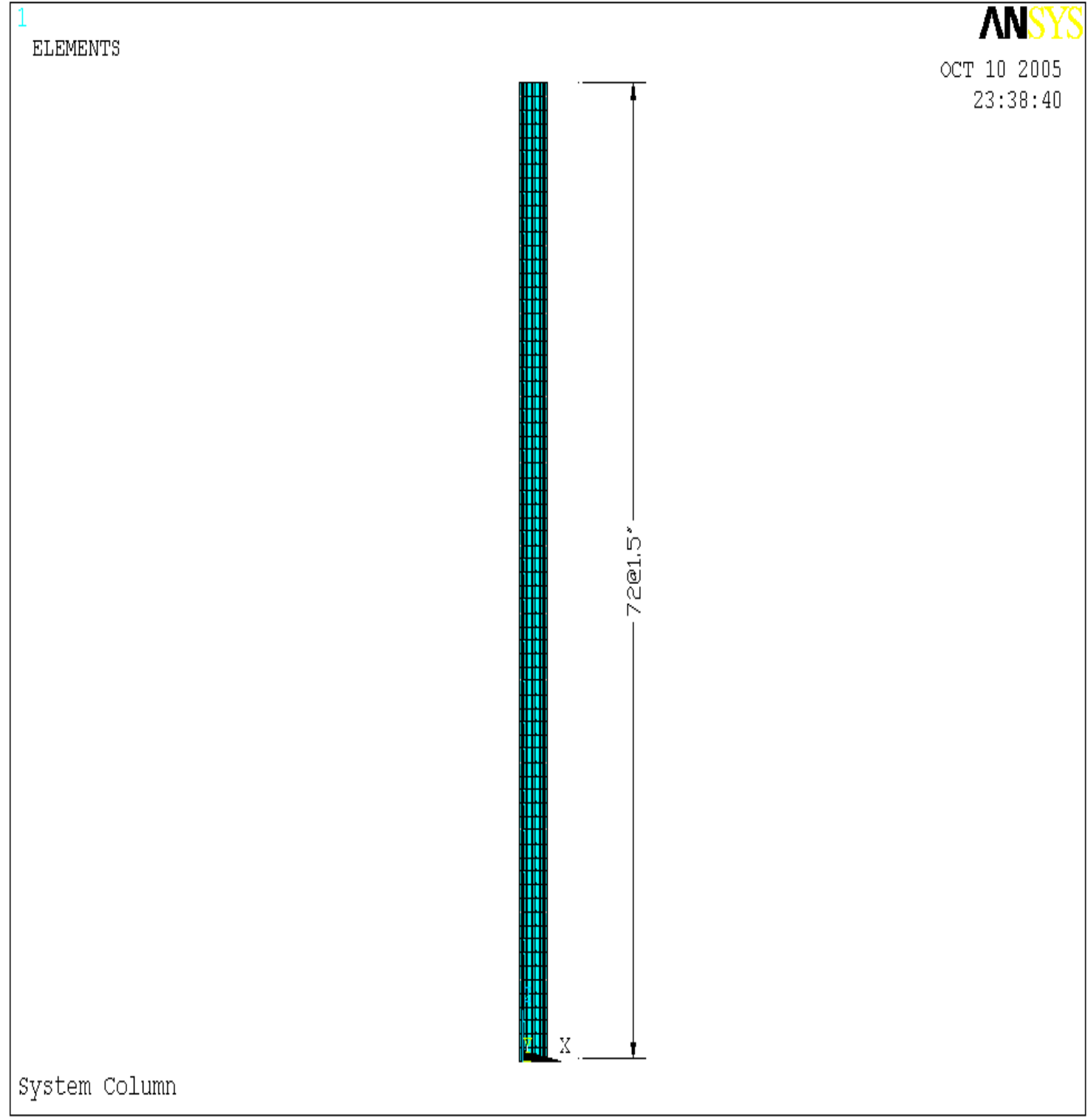

Figure 6.19 Elevation of the original column with foam

\subsubsection{Finite element model of the original column with foam}

Shell elements (Shell181) are used to model the metal facings and solid elements (Solid45) are used to model the foam between the facings. As shown in Figure 6.21, the model is restrained with pin supports at the top of the column and fix supports at the bottom except the rotation about $\mathrm{x}$ direction. 


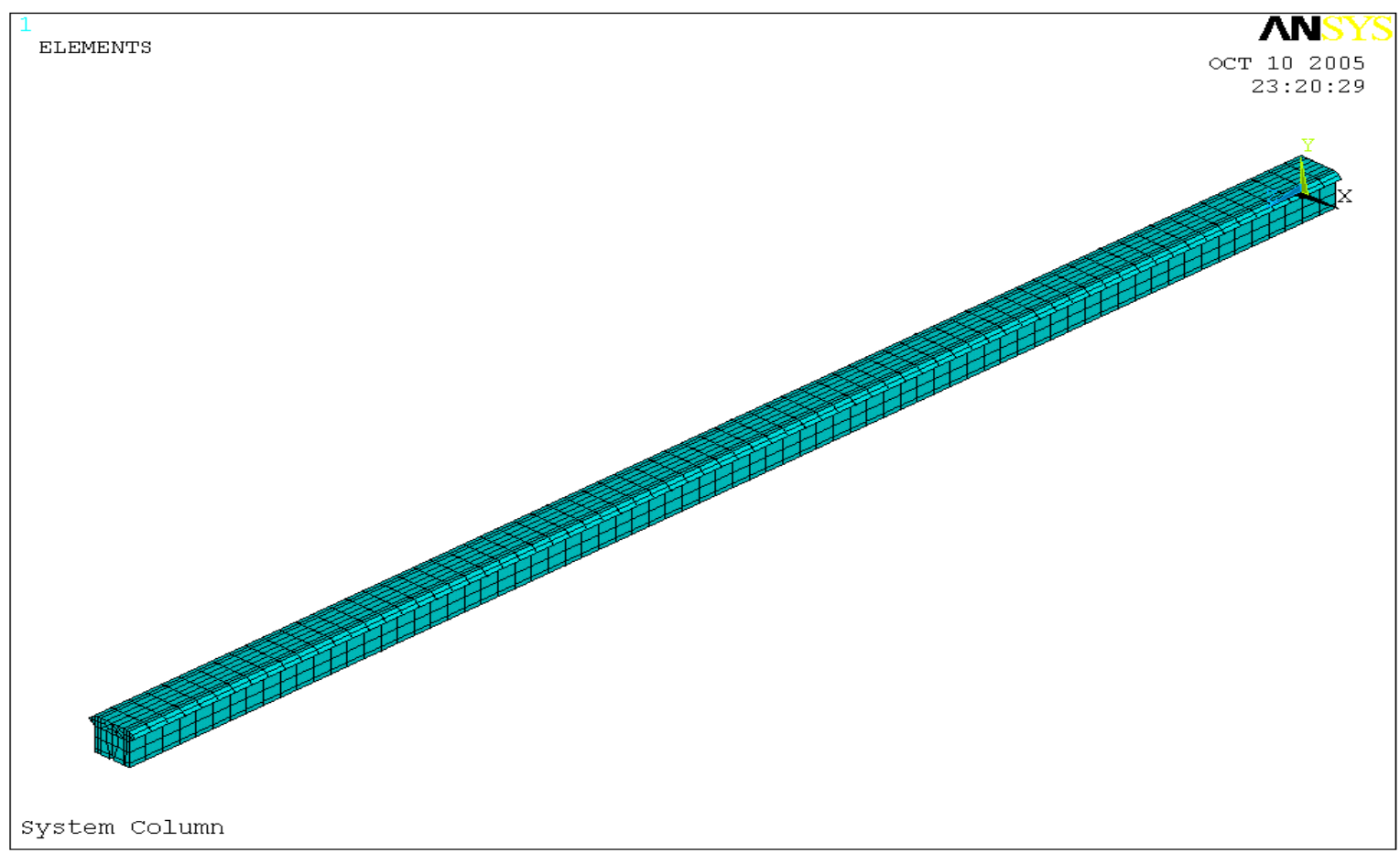

Figure 6.20 Original column model with foam

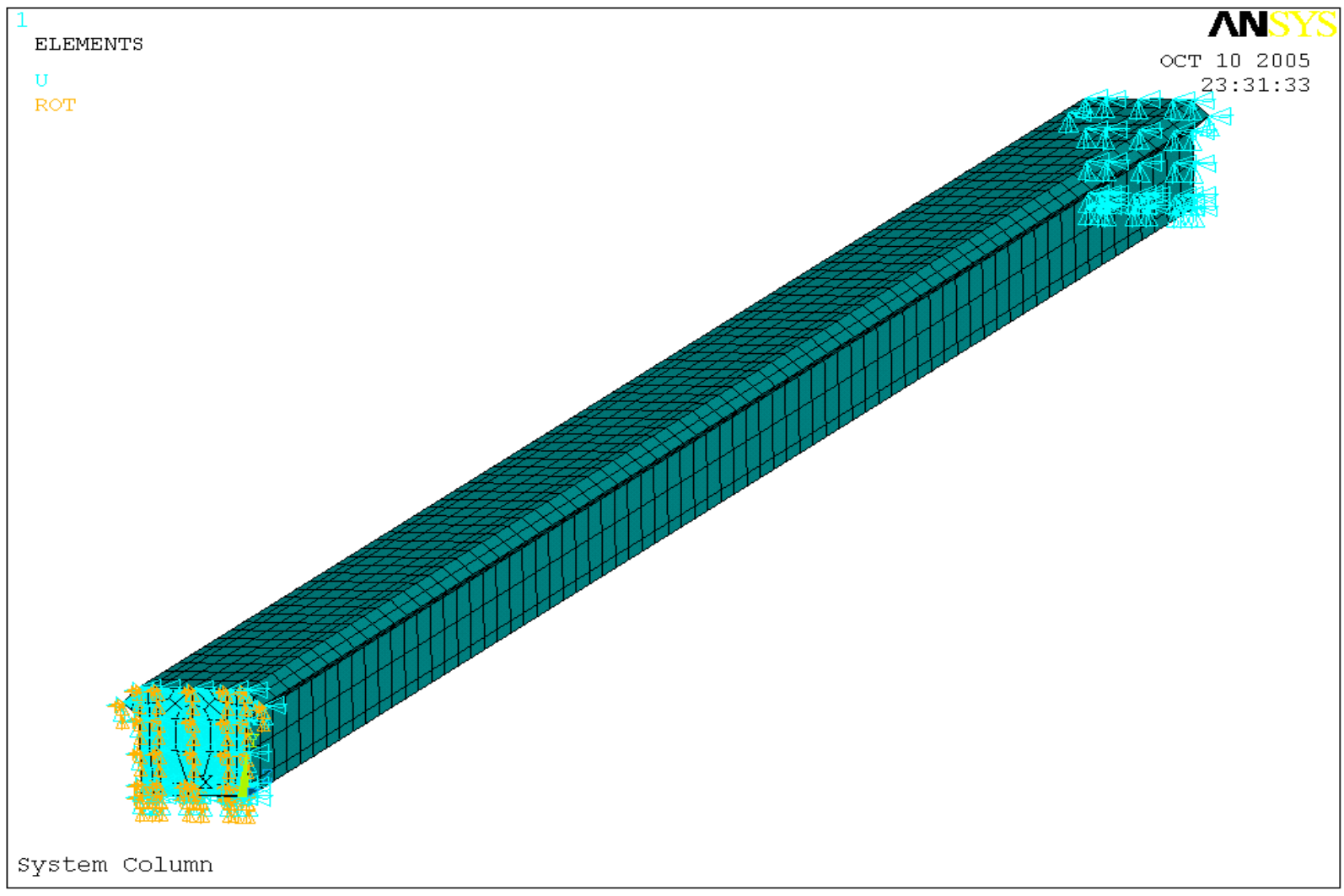

Figure 6.21 End restrains of the original column with foam 


\subsubsection{Loads}

Dead load - Self-weight of the original column made of 16 gage steel with foam:

Foam: 2.0545 lbs

Steel sheets: $16.75 \mathrm{lbs}$

Live load: $7604 p s f=52.807^{p s i}$, applied on the top of the original column.

Wind load: $19.60 p s f=0.136^{p s i}$, applied on the facing of the original column.

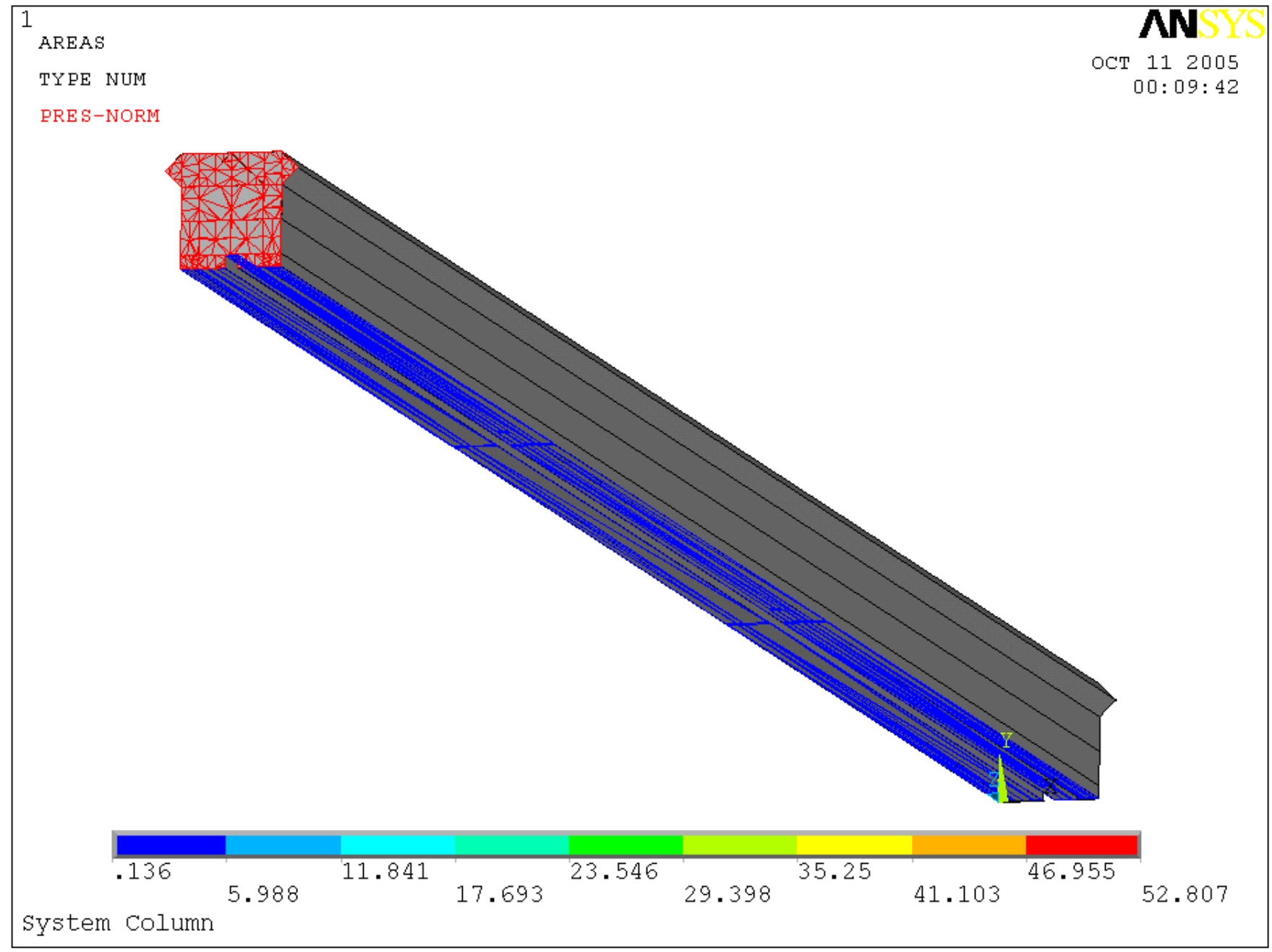

Figure 6.22 Loads on the original column with foam

(Positive values denote the pressure act into the areas) 


\subsection{Analytical Results of the Original Column with Foam}

6.4.1 Deformation of the original column with foam

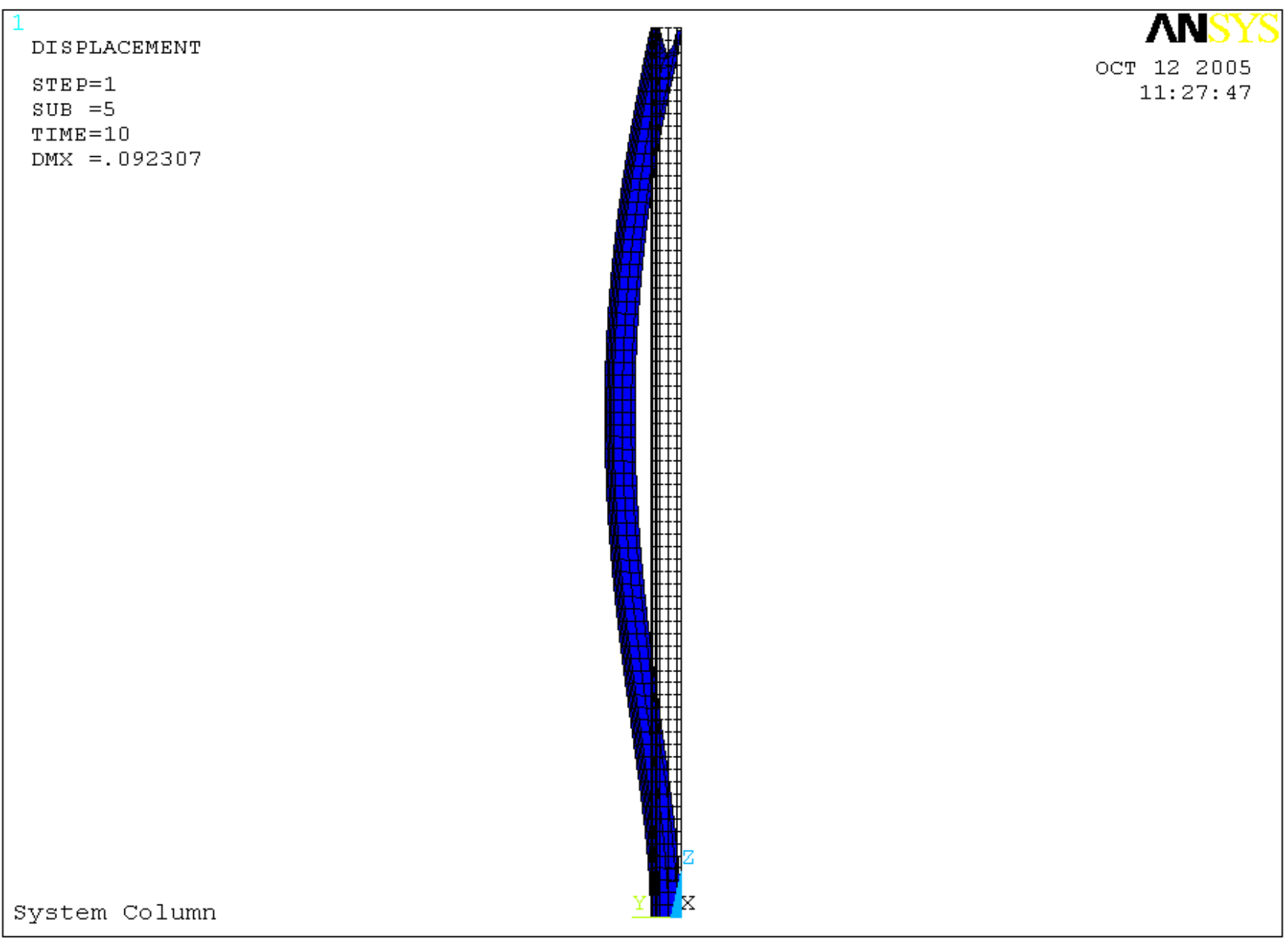

Figure 6.23 Deformation of the original column with foam (unit: inches) 
6.4.2 Stresses of the original column with foam

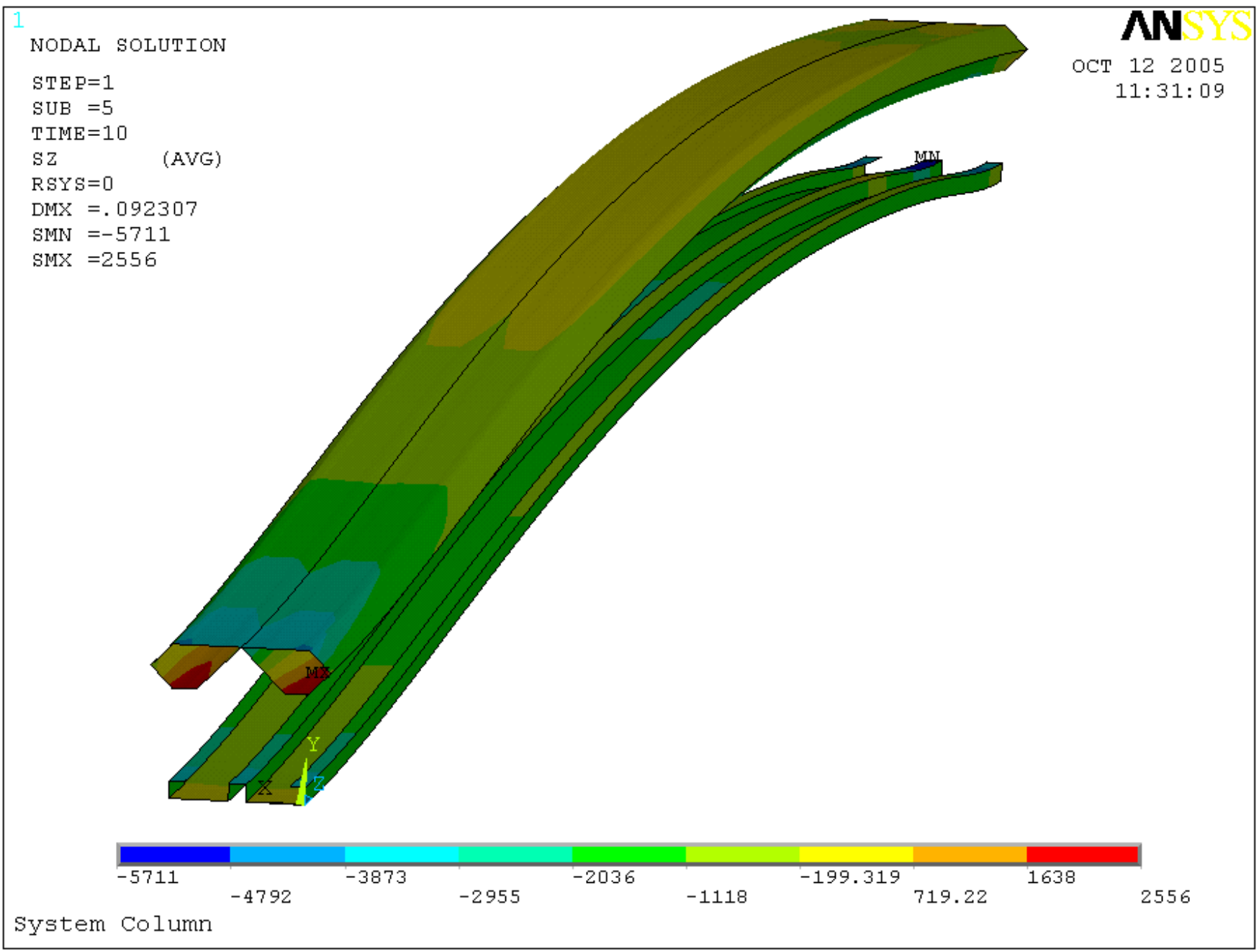

Figure 6.24 Stresses in the longitudinal direction at the steel facings (unit: psi) 


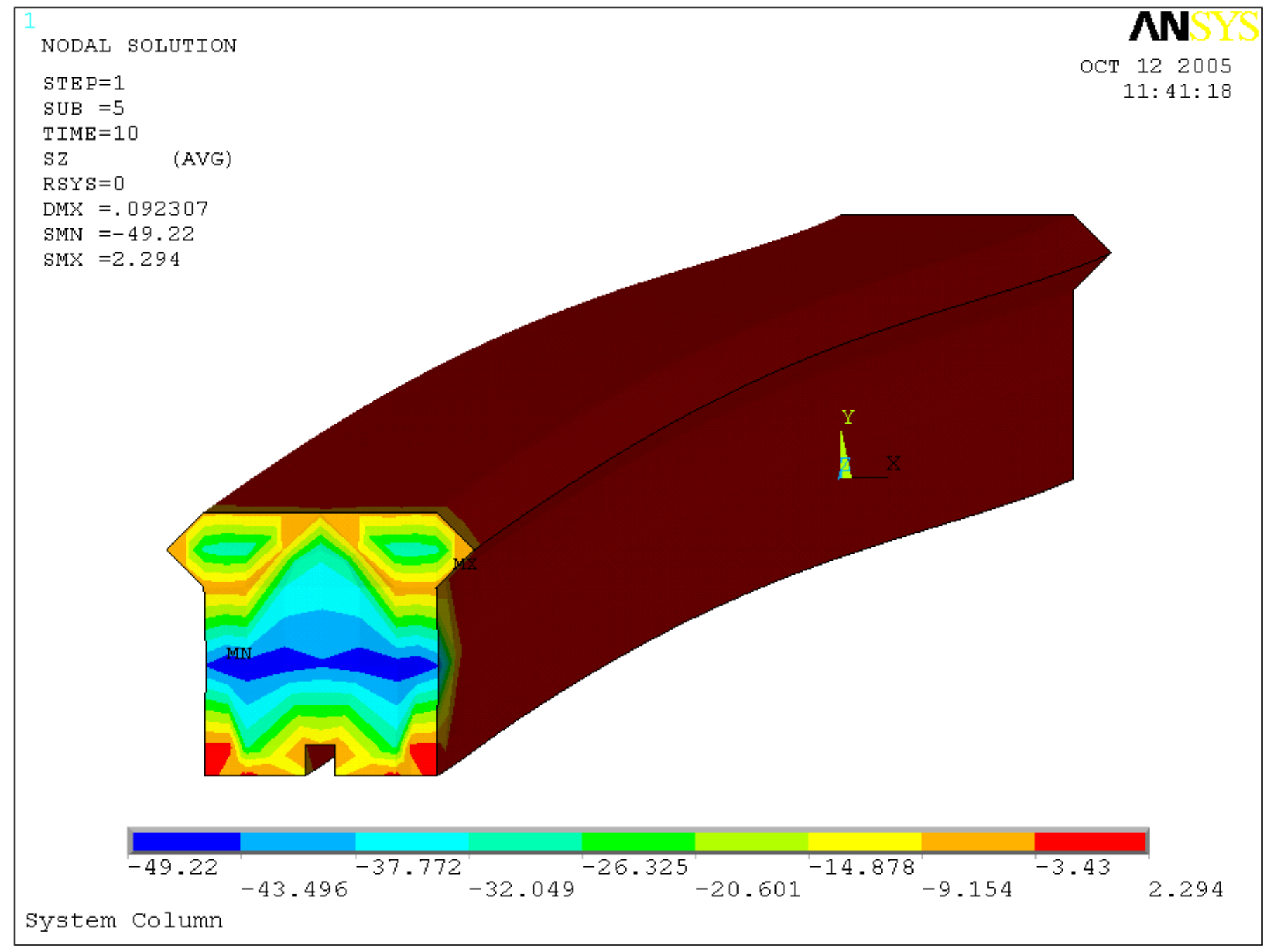

Figure 6.25 Stresses in the longitudinal direction in foam (unit: psi)

\subsubsection{Results comments of the original columns with foam}

(a) The maximum deformation in the system column occurs at about 46.5 " from the top surface.

(b) For the stresses in longitudinal direction, the maximum compressive stress occurs at 3" from the top of the front steel facing and the maximum tensile stress occurs at about 1.5" from the bottom surface of the middle steel facing. The maximum tensile and compressive stresses in the PU foam are 2.294 psi and 49.22 psi, respectively. 
Table 6.2 Summary of the maximum stresses in the original column with foam

\begin{tabular}{|c|c|c|}
\hline Element & $\begin{array}{c}\text { Maximum tensile } \\
\text { stress (psi) }\end{array}$ & $\begin{array}{c}\text { Maximum compressive } \\
\text { stress (psi) }\end{array}$ \\
\hline Steel sheet (front) & 1426 & 5711 \\
\hline Steel sheet (middle) & 2556 & 3187 \\
\hline Steel sheet (back) & 1242 & 4207 \\
\hline PU foam & 2.294 & 49.22 \\
\hline
\end{tabular}

(a) The stress in the PU foam was almost equal to zero compared to the stress in steel sheets; indicating steel facings carried most of the loads.

(b) The magnitude of deformation is dependent on the modulus of elasticity of foam, $E_{\text {foam }}$, as shown in Figure 6.26

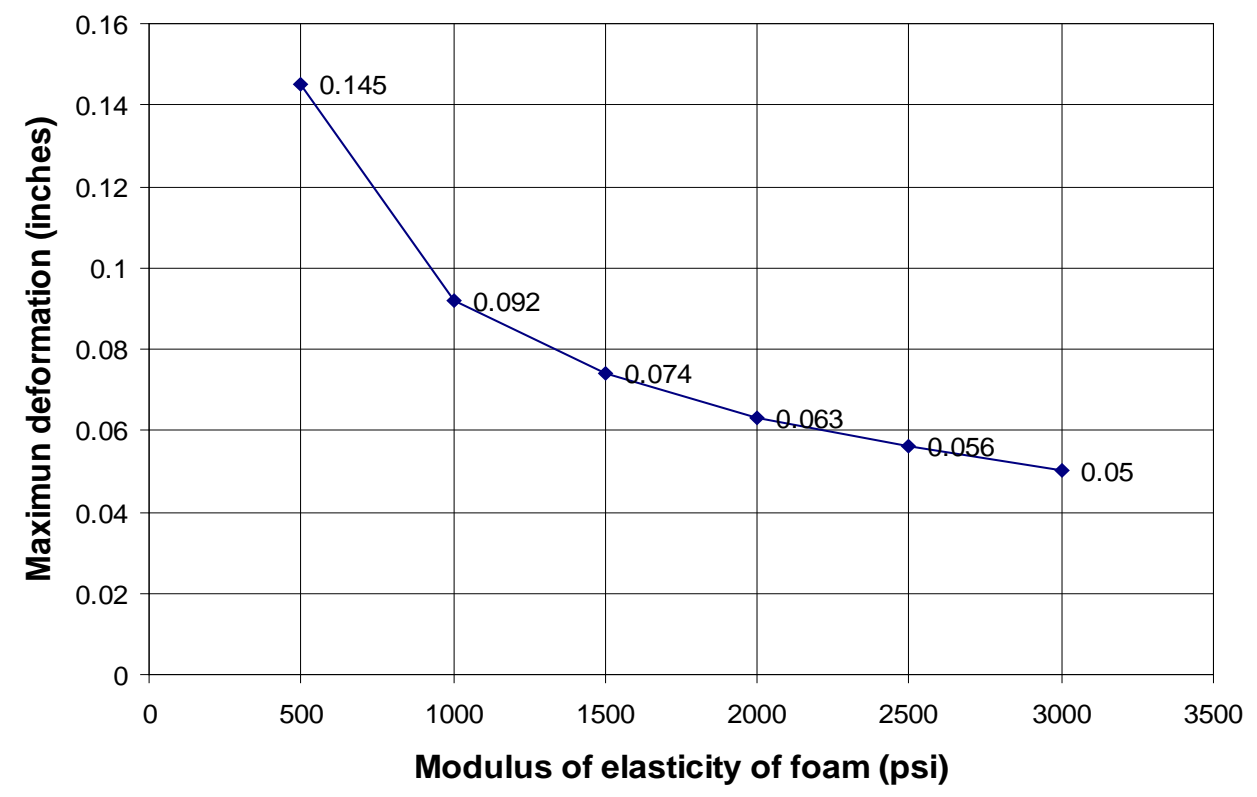

Figure 6.26 Maximum deformation of original column vs. modulus of elasticity of foam 



\section{CHAPTER 7}

\section{MODELING AND ANALYSIS OF THE WINDOW HEADER}

\subsection{Description of Input and Modeling of the window header}

\subsubsection{Dimensions and modeling of the window header}

The material properties of the window header are same as the panel and column. The window header made of 16 gage steel was studied.

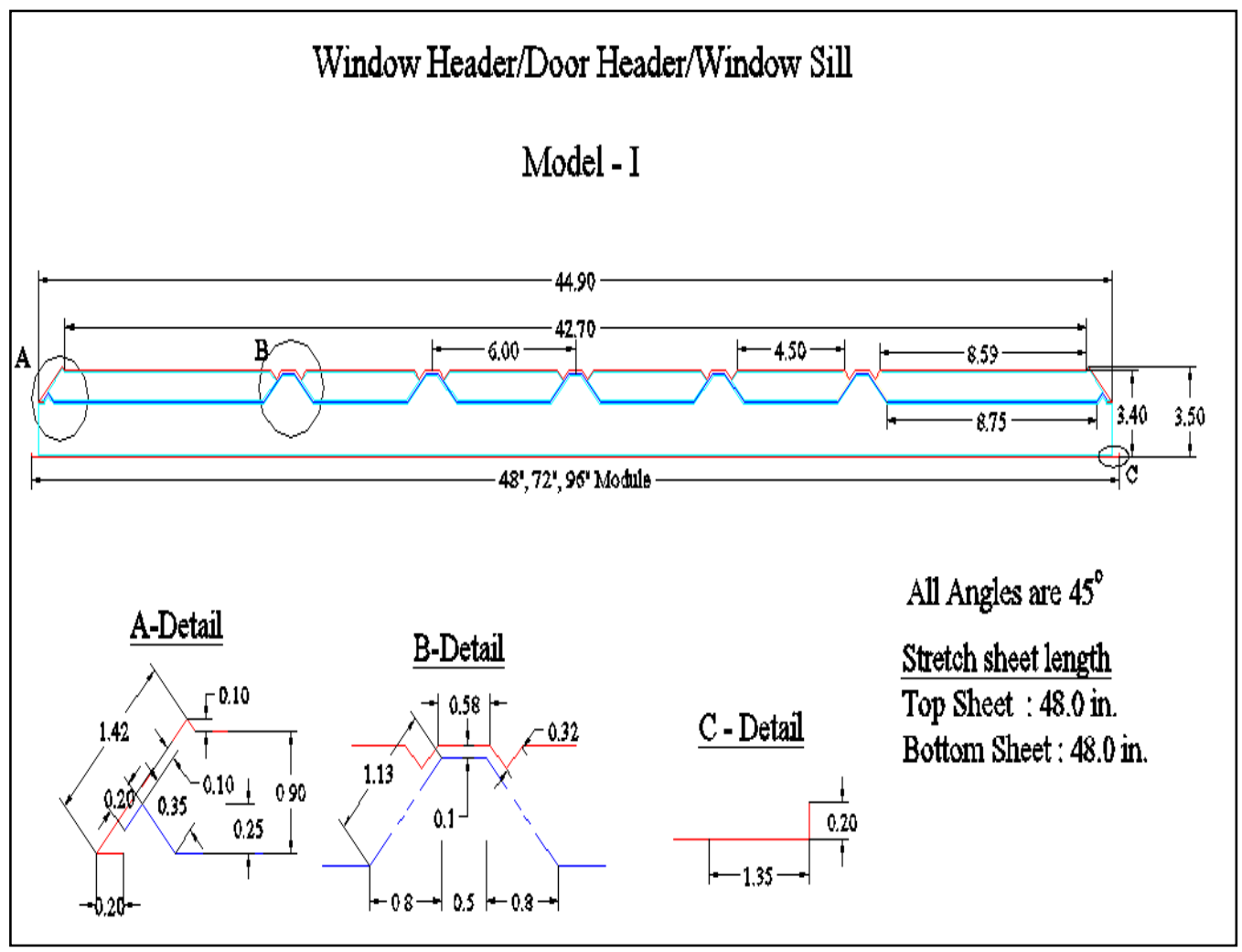

Figure 7.1 Cross-section of the window header model (unit: inches) 


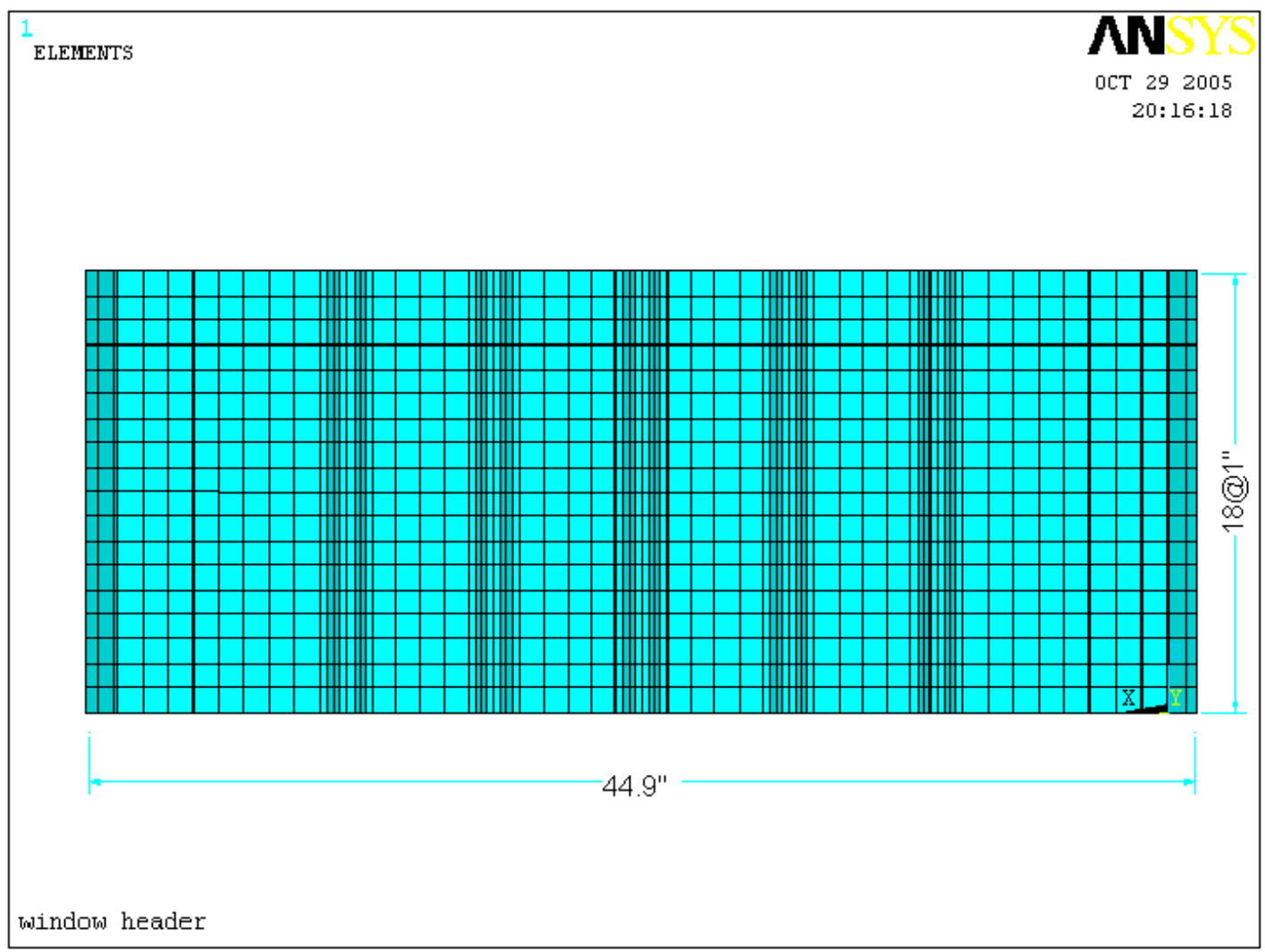

Figure 7.2 Elevation of the window header model

\subsubsection{Finite element model of the window header model}

Shell elements (Shell181) were used to model the header's metal facings and solid elements (Solid45) were used to model the foam between the facings. As shown in Figure 7.4, pin supports were applied on the ends of the bottom of the window header, and translation restraints in $\mathrm{X}$ and $\mathrm{Y}$ directions were applied on the top of the header at the positions of columns. 


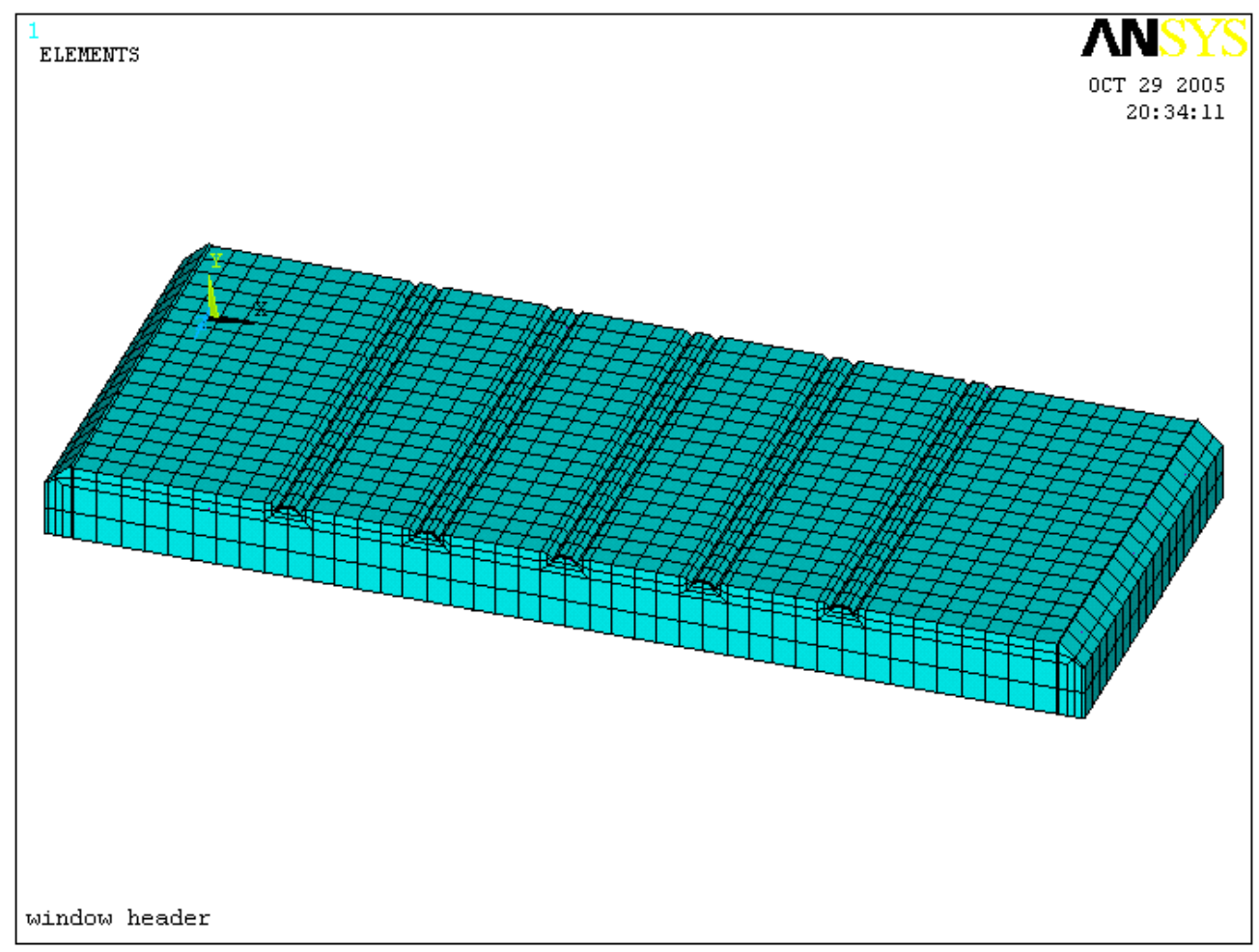

Figure 7.3 Window header finite element model

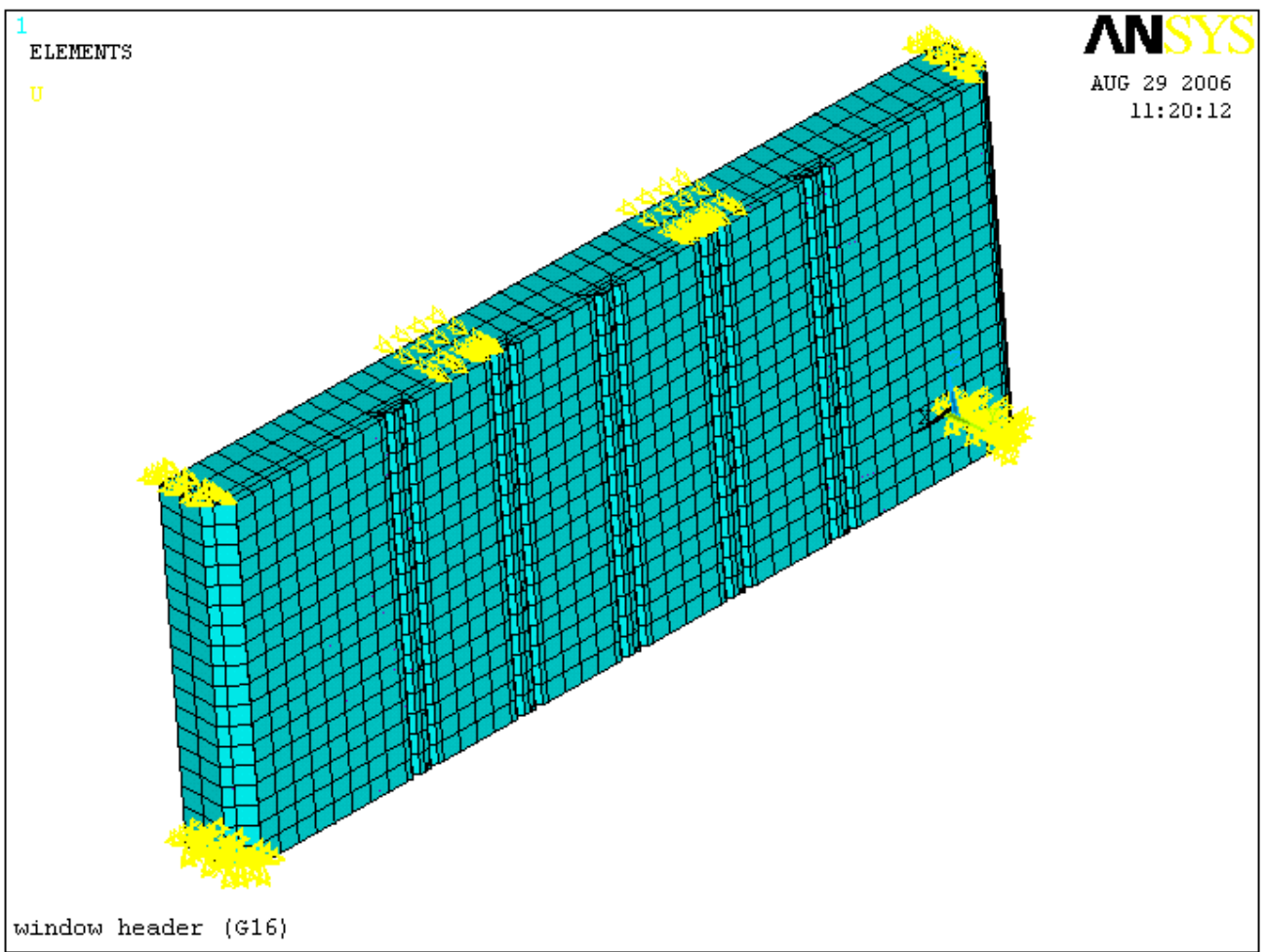

Figure 7.4 Window header model with end restrains 


\subsubsection{Loads}

Dead load - Self-weight of the window header:

Foam: $4.65 \mathrm{lbs}$

Steel sheets: $26.72 \mathrm{lbs}$

Live load: $1.164^{p s i}$, applied on the top C-shape track of the window header.

Wind load: $19.60^{p s f}=0.136^{p s i}$, applied on the curved facing of the window header.

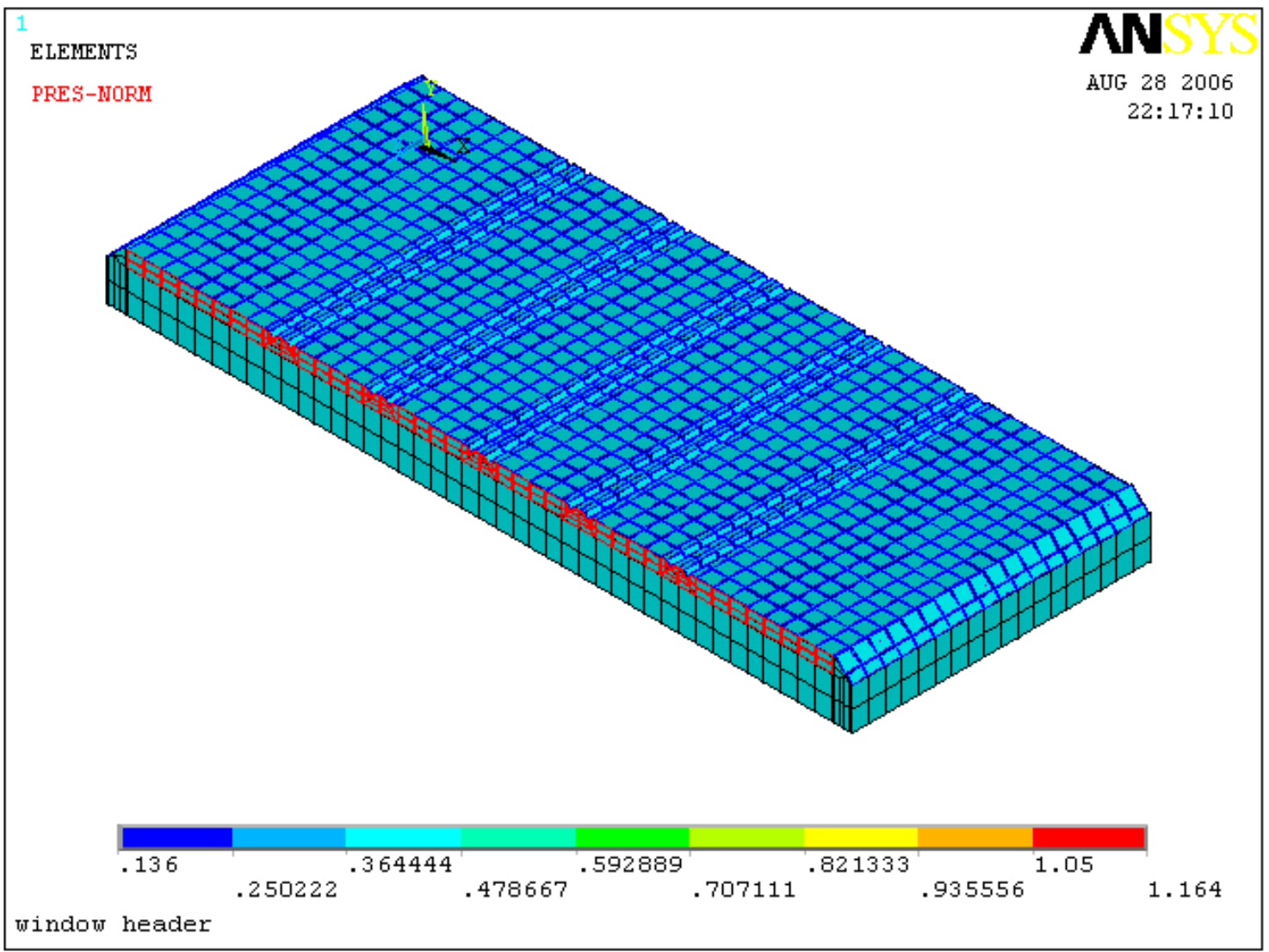

Figure 7.5 Loads on the window header model

(Positive values denote the pressure act into the areas) 


\subsection{Analytical results of the window header}

Figure 7.6 shows the deformation of the window header with Gage 16. Figures 7.7 through 6.10 show the stresses of window header under the load Case 1.

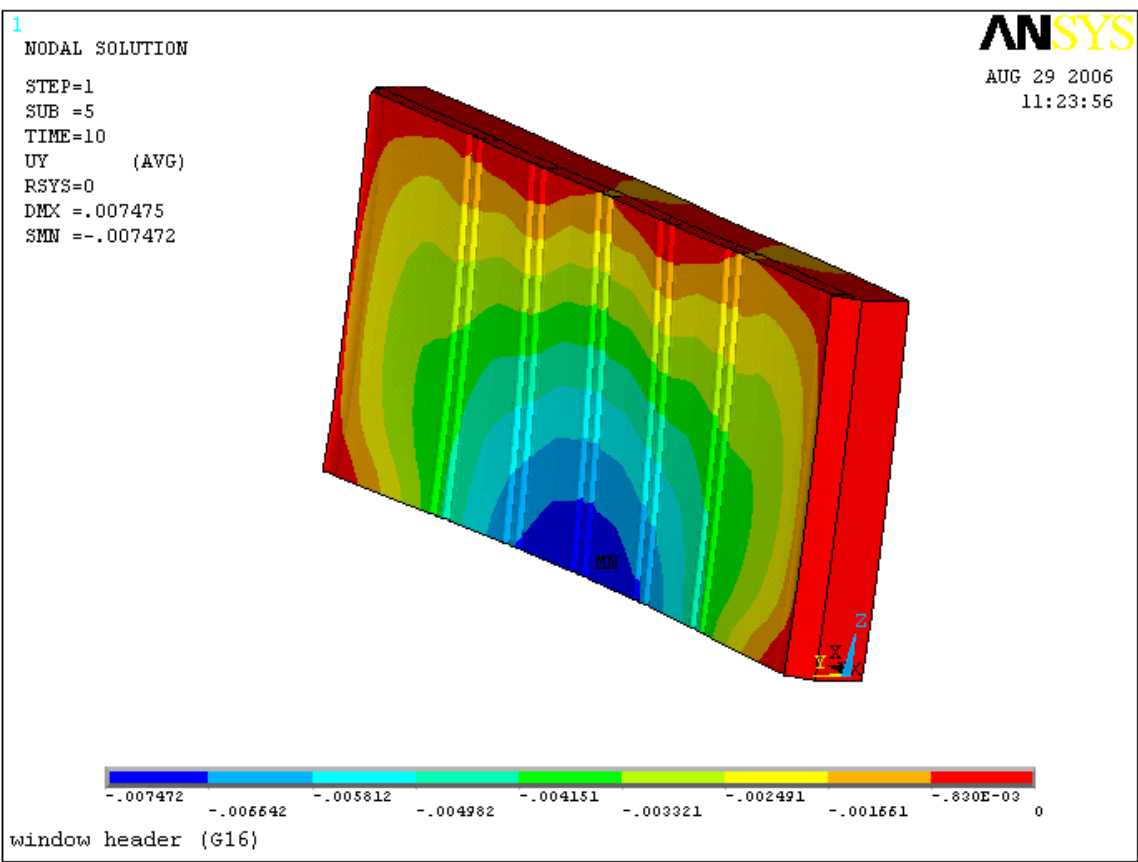

Figure 7.6 Deformation of the window header model (unit: inches)

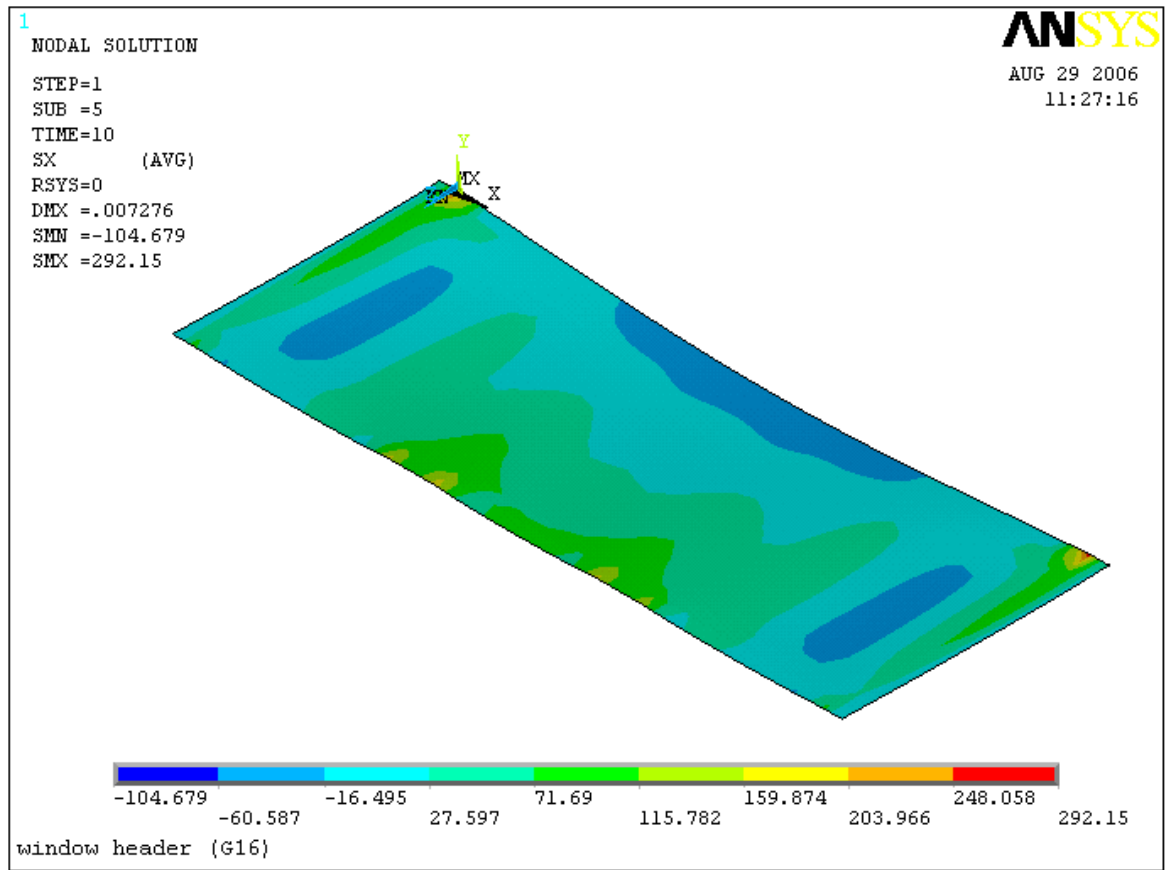

Figure 7.7 Stresses in $\mathrm{x}$ direction in the back steel facing $\mathrm{y}=\mathbf{0}$ (unit: psi) 


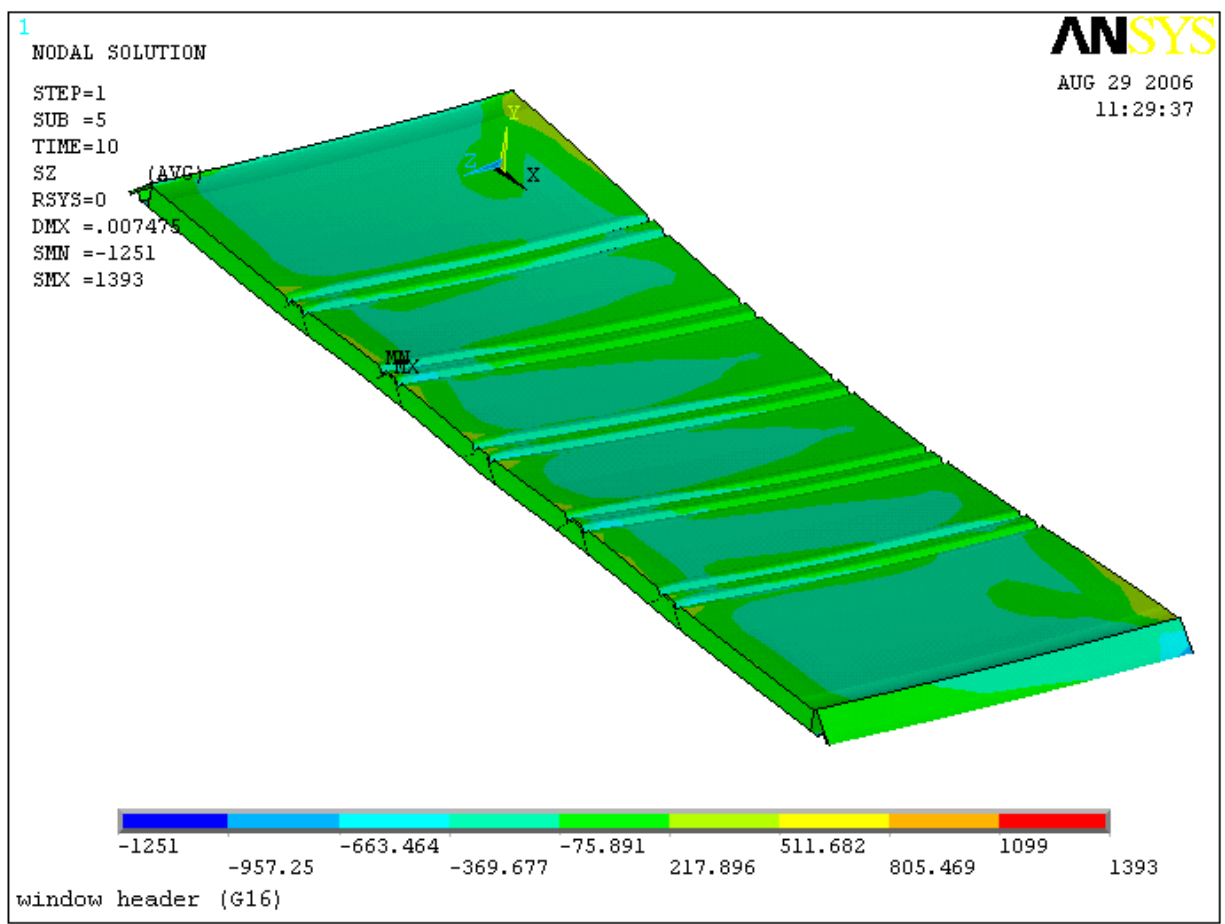

Figure 7.8 Stresses in longitudinal direction in the front steel facing (unit: psi)

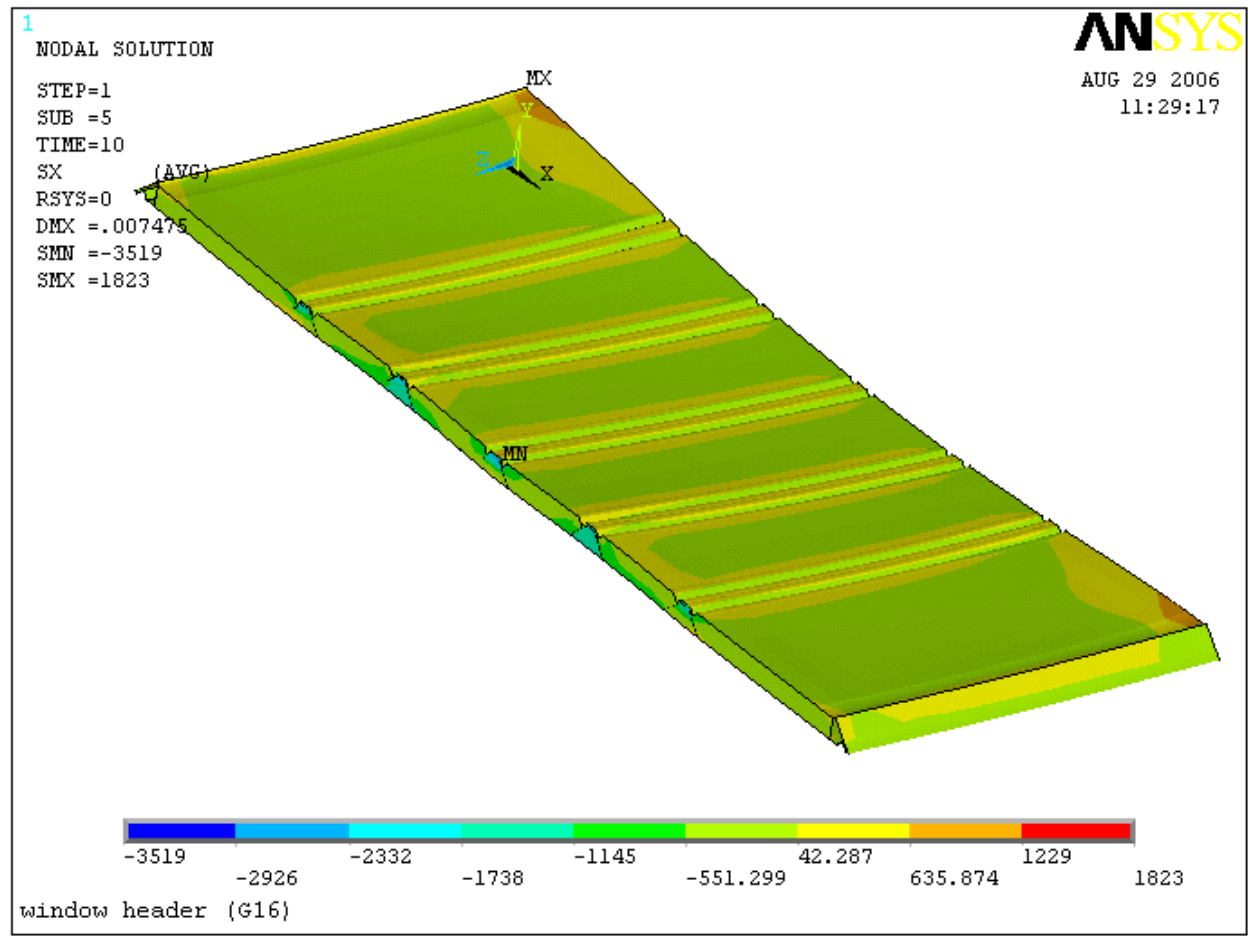

Figure 7.9 Stresses in $\mathrm{x}$ direction in the front steel facing (unit: psi) 


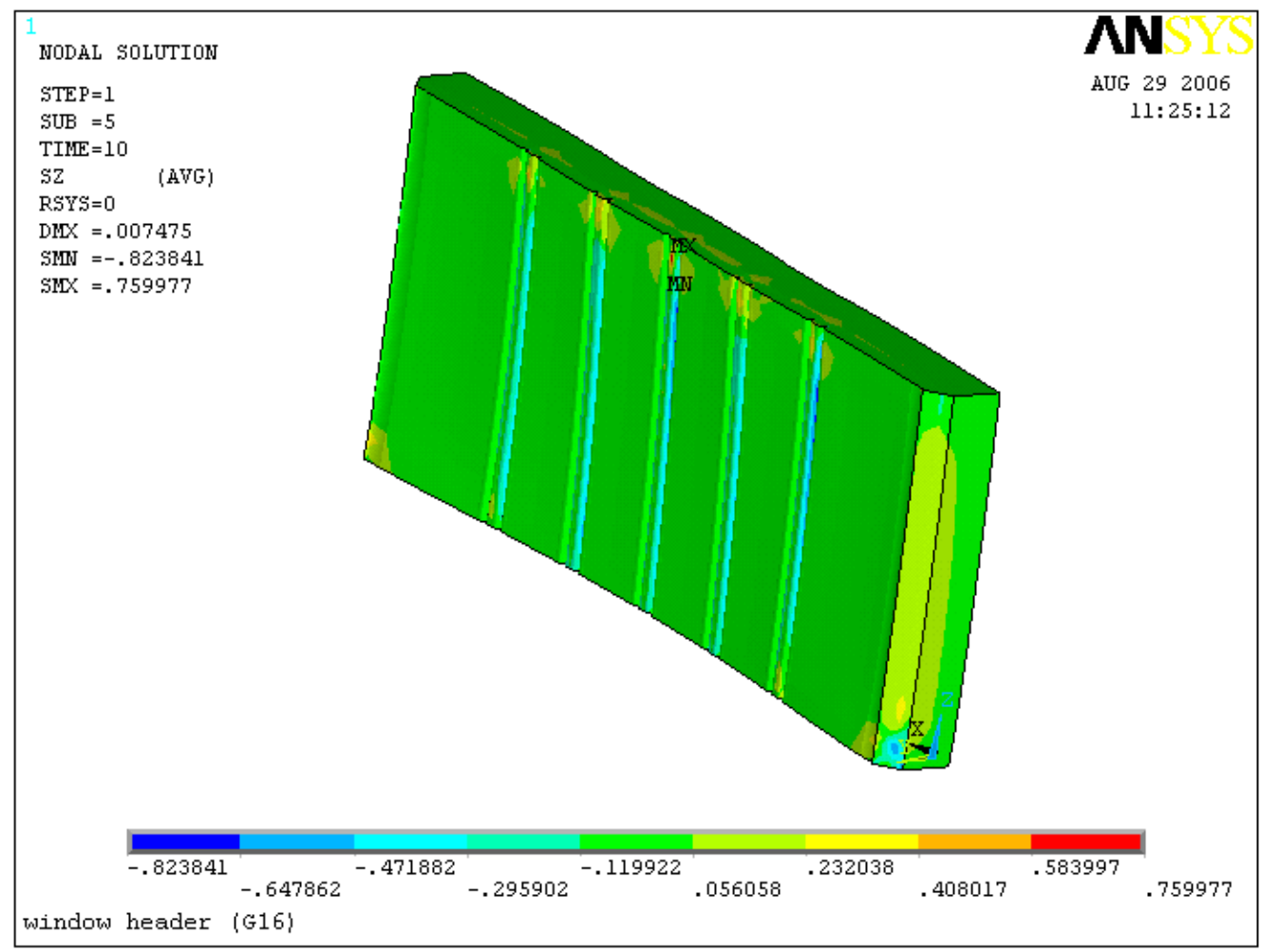

Figure 7.10 Stresses in longitudinal direction in foam (unit: psi)

It was observed that the maximum deformation in the window header occurred at the bottom of the front steel facing $(y=2.5 \mathrm{ft})$. For the stresses in longitudinal direction, the maximum compressive stress and the maximum tensile stress occurred at the top of the front steel facing. The stress in the PU foam was almost equal to zero; indicating steel facings carried most of the loads.

Table 7.1 Summary of the maximum stresses in the window header

\begin{tabular}{ccc}
\hline Element & $\begin{array}{c}\text { Maximum positive } \\
\text { stress (Tension) } \\
(\mathrm{psi})\end{array}$ & $\begin{array}{c}\text { Maximum negative } \\
\text { stress (Compression) } \\
(\mathrm{psi})\end{array}$ \\
\hline Steel sheets (front) & 1823 & 3519 \\
\hline Steel sheet (back) & 104.68 & 292.15 \\
\hline PU foam & 0.82 & 0.76 \\
\hline
\end{tabular}




\subsection{Capability of the Window Header}

When the wind load was kept unchanged (Wind load: $0.136 \mathrm{psi}$, applied on the shaped facing of the window header), the maximum vertical live load on the window header could be obtained based on allowable stress in steel facings. Figure 7.11 through 7.15 shows the deformations and stresses under the maximum live load on the window header.

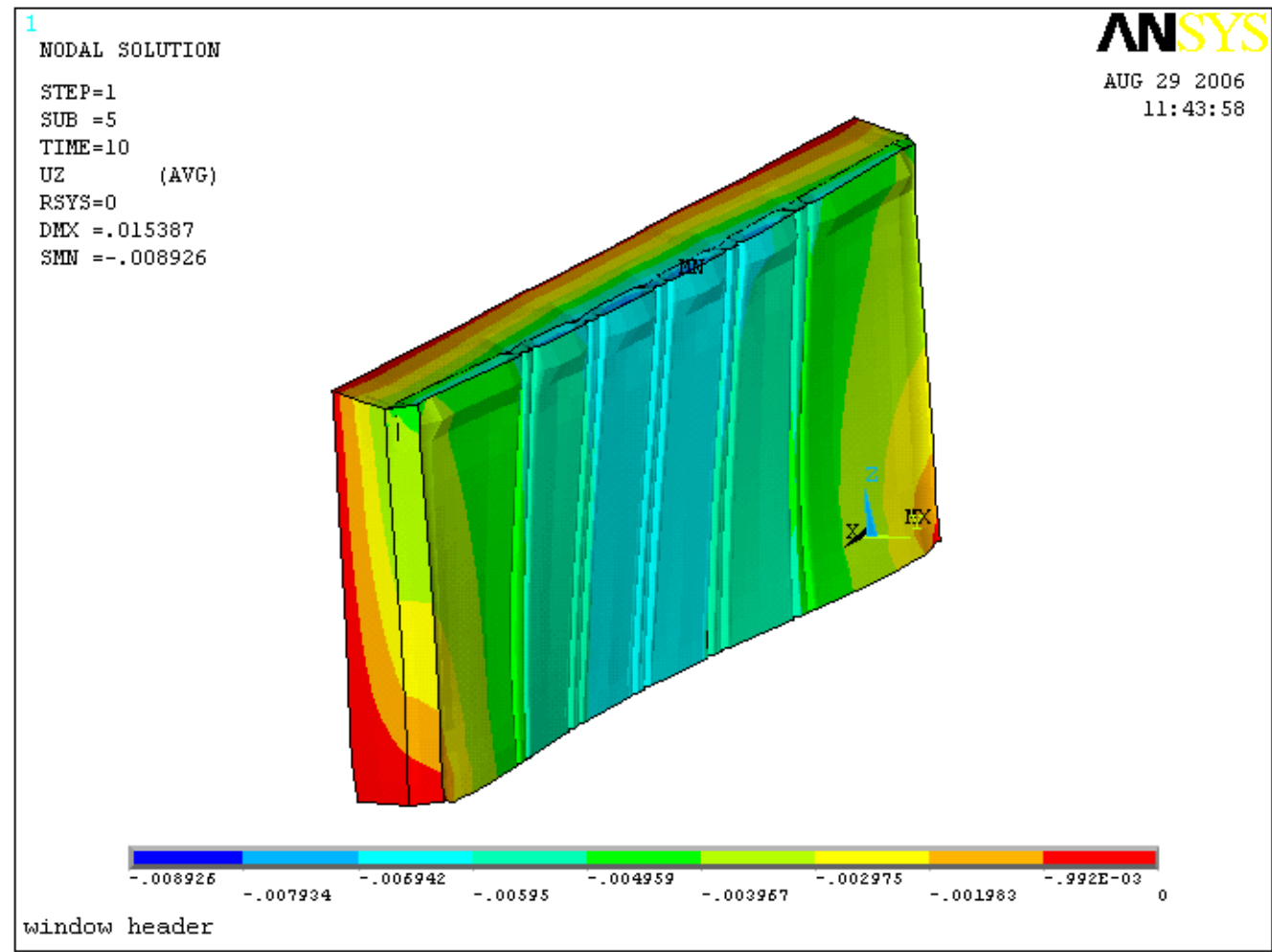

Figure 7.11 Deformation of the window header model (unit: inches) 


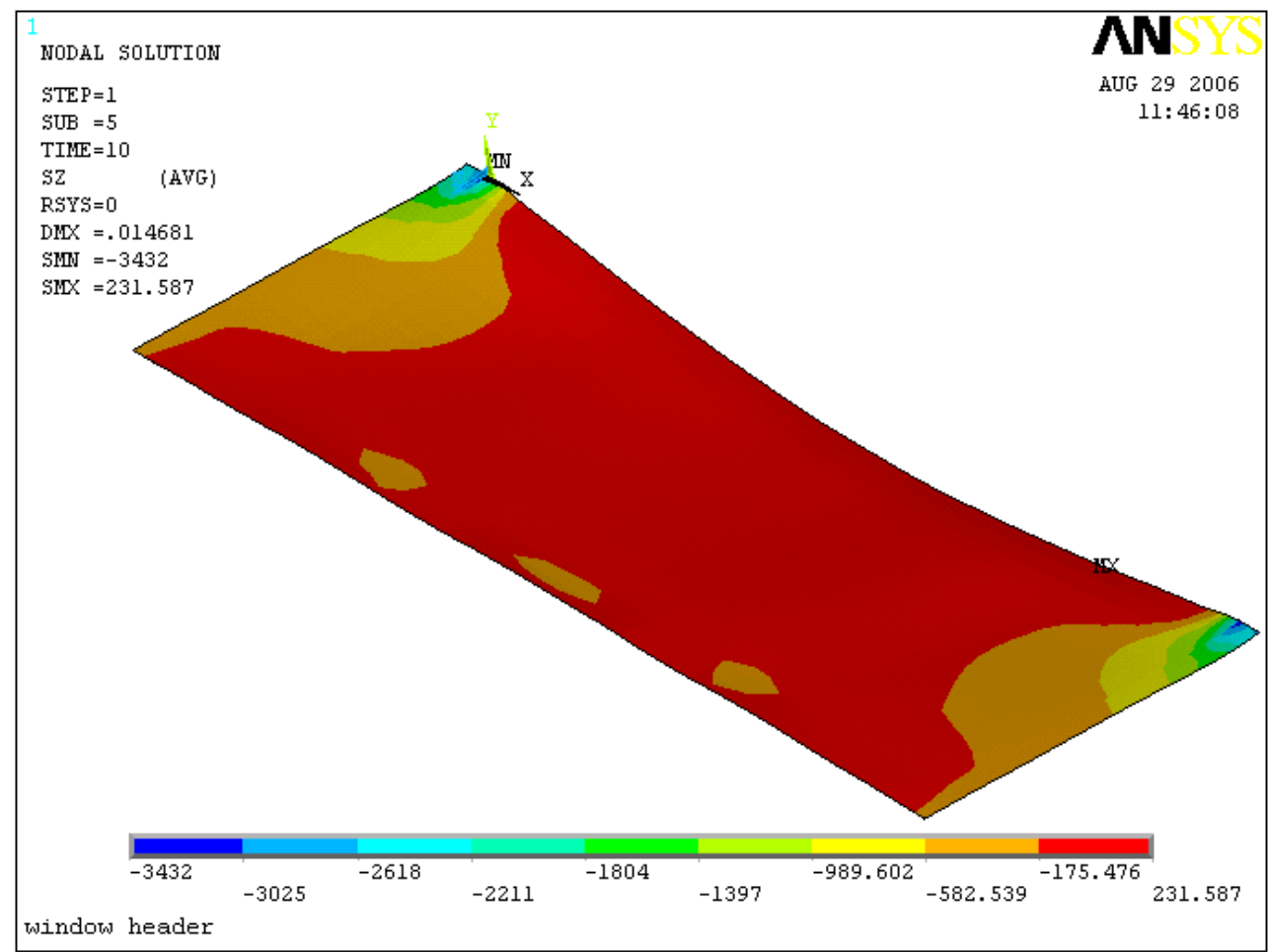

Figure 7.12 Stresses in longitudinal direction in the back steel facing $y=0$ (unit: psi)

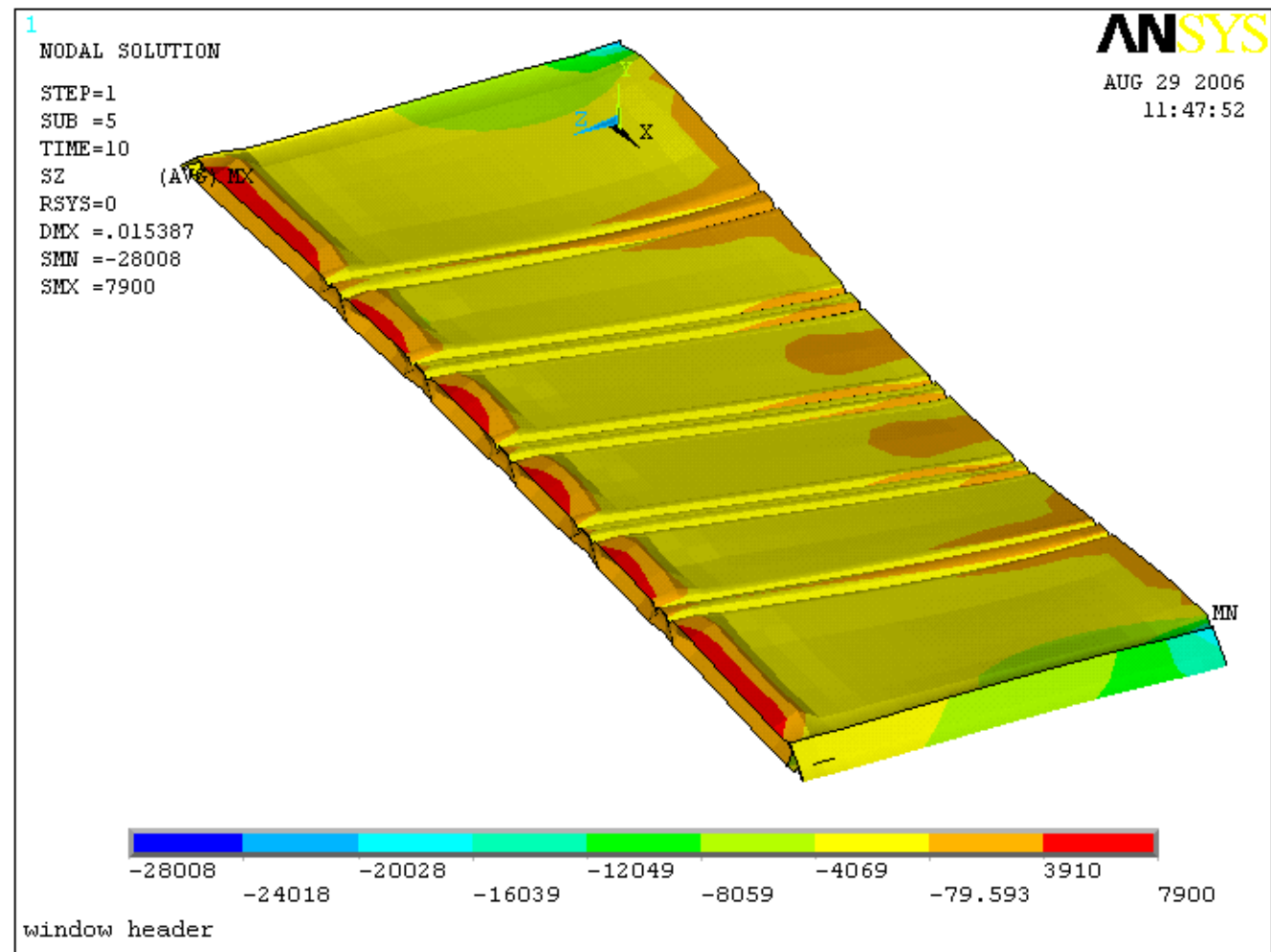

Figure 7.13 Stresses in longitudinal direction in the front steel facing (unit: psi) 


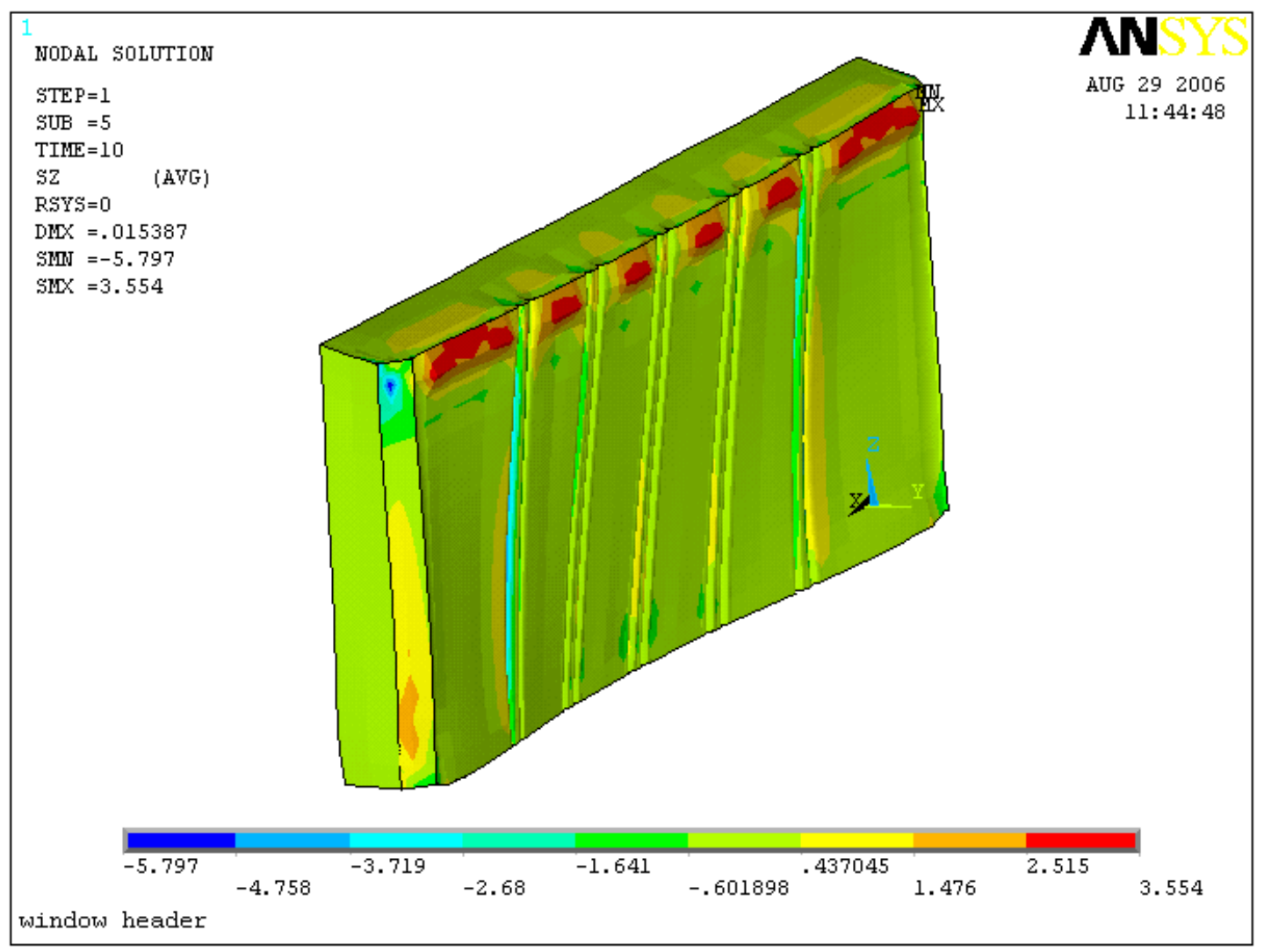

Figure 7.14 Stresses in longitudinal direction in foam (unit: psi)

Under the maximum vertical load, the window header exhibited the same performance as the normal load case - load Case 1. The maximum deformation of the window header was 0.0154 inch which occurred at the midsapn, bottom of the header. Under the larger vertical live load, the maximum stress in steel facing was 28,000 psi while the maximum stress in foam was only 5.797 psi, which showed the steel facings carry majority of the applied loads. The maximum negative stress of the window header occurred at the bottom of the front steel facings and close to the supports. The maximum positive stress occurred in the steel facing at the top of the header. 


\section{CHAPTER 8}

\section{CONCLUSION AND RECOMMENDATION}

\subsection{Conclusion and recommendation about the basic panel}

1. For all the panels of metal facings made of 24, 25 and 26 gage steel studied, the maximum deformation occurred at about middle height of the panels. The magnitude of deformation decreased with the modulus of elasticity of foam increased. Under self-weight, wind load and live load, the maximum deformation was less than the limit of the code when the modulus of elasticity was 1000 psi.

2. The maximum tensile stress in longitudinal direction occurred at the bottom of the front steel facing and the maximum compressive stress occurred at about 45" from the top surface of

the front steel facing. Under the normal loads (load Case 1), the stress of foam was much smaller than the stress of the steel facing, and the stress of the foam could be neglected. For example, in the panel made of 24 gage steel, the maximum stress of the foam was 13.565 psi while the maximum stress of the steel facing was 11428 psi.

3. In determination of the vertical load capacity, the stress in the foam was a key factor for the maximum value of the vertical load and the stress of the steel facing did not change much. In pursuing the horizontal wind load capacity, the stress of the steel facing was a key factor while the stress of the foam could be neglected because the steel facings carried almost all the loads. 


\subsection{Conclusions and recommendations about the system column}

\subsubsection{Comparison of Slenderness Ratio}

The slenderness ratio was an important term for columns behavior. According to the AISC LRFD Specifications, Article B7, the slenderness ratio of a compression member, KL/r, should not exceed 200. The calculations of the slenderness ratio of all columns are shown in the following.

Table 8.1 Comparison of Slenderness Ratio for the Studied columns

\begin{tabular}{|c|c|c|c|c|c|c|c|c|c|c|}
\hline & \multicolumn{4}{|c|}{ C-shape column } & \multicolumn{3}{|c|}{ Delta-shape column } & \multicolumn{3}{|c|}{ Original column } \\
\hline & $\begin{array}{l}16 \mathrm{G}- \\
\mathrm{C} 2 \times 4\end{array}$ & $\begin{array}{l}16 \mathrm{G}- \\
\mathrm{C} 2 \times 6 \\
\end{array}$ & $\begin{array}{l}20 \mathrm{G}- \\
\mathrm{C} 2 \times 4\end{array}$ & $\begin{array}{l}20 \mathrm{G}- \\
\mathrm{C} 2 \times 6 \\
\end{array}$ & $16 \mathrm{G}$ & $18 \mathrm{G}$ & $20 \mathrm{G}$ & $16 \mathrm{G}$ & $18 \mathrm{G}$ & $20 \mathrm{G}$ \\
\hline $\mathrm{A}\left(\mathrm{in}^{2}\right)$ & 0.3919 & 0.5086 & 0.2353 & 0.3071 & 1.4352 & 1.1472 & 0.8616 & 0.5894 & 0.4711 & 0.3538 \\
\hline I $\left(\mathrm{in}^{4}\right)$ & 0.7598 & 2.1565 & 0.4561 & 1.3143 & 0.603 & 0.4819 & 0.3619 & 0.085 & 0.0679 & 0.051 \\
\hline r (in.) & 1.3924 & 2.059 & 1.3923 & 2.069 & 0.6482 & 0.6481 & 0.6480 & 0.3798 & 0.3796 & 0.38 \\
\hline L (in.) & 108.0 & 108.0 & 108.0 & 108.0 & 108.0 & 108.0 & 108.0 & 108.0 & 108.0 & 108.0 \\
\hline $\mathrm{KL} / \mathrm{r}$ & 77.56 & 52.5 & 77.6 & 52.2 & 166.61 & 166.64 & 166.67 & 284.4 & 284.5 & 284.2 \\
\hline
\end{tabular}

Note:

1. I is the least moment of inertia of the column section;

2. $r=\sqrt{\frac{I_{33}}{A}}$.

According to Table 8.1, the slenderness ratios of the C-shape and Delta-shape columns were less than the limitation of slenderness ratio 200, while the slenderness ratios of the original columns were greater than the limit. 


\subsubsection{Comparison of deformations and stresses for columns under load Case 1}

Table 8.2 Deformations and Stresses of the Studied Columns under Load Case 1

\begin{tabular}{|c|c|c|c|c|c|c|c|}
\hline $\begin{array}{c}\text { Steel } \\
\text { thickness }\end{array}$ & Column & $\begin{array}{l}\text { Maximum } \\
\text { Deflection } \\
\quad \text { (in.) }\end{array}$ & $\begin{array}{c}\text { Maximum } \\
\text { Rotation } \\
\text { (rad.) }\end{array}$ & $\begin{array}{c}\text { Maximum } \\
\text { positive } \\
\text { stress } \\
\text { (Tension) } \\
\text { (psi) } \\
\end{array}$ & $\begin{array}{c}\text { Maximum } \\
\text { negative stress } \\
\text { (Compression) } \\
\text { (psi) }\end{array}$ & $\begin{array}{c}\text { Slenderness } \\
\text { ratio } \\
(\mathrm{KL} / \mathbf{r})\end{array}$ & $\begin{array}{l}\text { Check } \\
\text { Code }\end{array}$ \\
\hline \multirow{2}{*}{16 Gage } & $\begin{array}{c}2 \times 4 \\
\text { C-shape }\end{array}$ & 0.0678 & 0.0232 & --- & 6132 & 77.56 & OK \\
\hline & $\begin{array}{c}2 \times 6 \\
\text { C-shape }\end{array}$ & 0.0335 & 0.0097 & --- & 4492 & 52.5 & OK \\
\hline \multirow{2}{*}{20 Gage } & $\begin{array}{c}2 \times 4 \\
\text { C-shape }\end{array}$ & 0.1424 & 0.0503 & --- & 11,130 & 77.6 & OK \\
\hline & $\begin{array}{c}2 \times 6 \\
\text { C-shape }\end{array}$ & 0.0644 & 0.0202 & --- & 8108 & 52.2 & OK \\
\hline 16 Gage & $\begin{array}{l}\text { Delta- } \\
\text { shape }\end{array}$ & 0.0232 & 0 & --- & 2401 & 166.61 & OK \\
\hline 18 Gage & $\begin{array}{l}\text { Delta- } \\
\text { shape }\end{array}$ & 0.0302 & 0 & --- & 3042 & 166.64 & OK \\
\hline 20 Gage & $\begin{array}{l}\text { Delta- } \\
\text { shape }\end{array}$ & 0.0430 & 0 & --- & 4140 & 166.67 & OK \\
\hline 16 Gage & $\begin{array}{l}\text { Original } \\
\text { column }\end{array}$ & 0.1291 & 0 & 522.701 & 6759 & $\underline{284.4}$ & NG \\
\hline 18 Gage & $\begin{array}{l}\text { Original } \\
\text { column }\end{array}$ & 0.1616 & 0 & 609.441 & 8439 & $\underline{284.5}$ & NG \\
\hline 20 Gage & $\begin{array}{l}\text { Original } \\
\text { column }\end{array}$ & 0.2153 & 0 & 751.432 & 11,217 & $\underline{284.2}$ & NG \\
\hline
\end{tabular}

Note:

1. Limitations:

a. The limitation of steel stress $\phi F_{\text {steel }}=0.85 \times 33=28.05 \mathrm{ksi}$.

b. The limitation of panel deformation is $\mathrm{L} / 360=0.30$ inch.

c. The limitation of slenderness ratio is 200 .

2. The underlined values are unacceptable compared with the above limitations. 


\subsubsection{Comparison of deformations and stresses for columns under load Case 2}

Table 8.3 Deformations and Stresses of the Studied Columns under Load Case 2

\begin{tabular}{|l|c|c|c|c|c|c|c|}
\hline $\begin{array}{c}\text { Steel } \\
\text { thickness }\end{array}$ & Column & $\begin{array}{c}\text { Maximum } \\
\text { Deflection } \\
\text { (in.) }\end{array}$ & $\begin{array}{c}\text { Maximum } \\
\text { Rotation } \\
\text { (rad.) }\end{array}$ & $\begin{array}{c}\text { Maximum } \\
\text { positive } \\
\text { stress } \\
\text { (Tension) } \\
\text { (psi) }\end{array}$ & $\begin{array}{c}\text { Maximum } \\
\text { negative stress } \\
\text { (Compression) } \\
\text { (psi) }\end{array}$ & $\begin{array}{c}\text { Slenderness } \\
\text { ratio } \\
\text { (KL/r) }\end{array}$ & $\begin{array}{c}\text { Check } \\
\text { Code }\end{array}$ \\
\hline & $\begin{array}{c}2 \times 4 \\
\text { C-shape }\end{array}$ & $\underline{1.079}$ & 0.370 & $\underline{31.102}$ & $\underline{45.051}$ & 77.56 & NG \\
\cline { 2 - 9 } & $\begin{array}{c}2 \times 6 \\
\text { C-shape }\end{array}$ & $\underline{0.529}$ & 0.156 & 19.16 & $\underline{32.216}$ & 52.5 & NG \\
\hline $\mathbf{1 6}$ Gage & $\begin{array}{c}\text { Delta- } \\
\text { shape }\end{array}$ & 0.2367 & 0 & 10,002 & 11,990 & 166.61 & OK \\
\hline $\mathbf{1 8}$ Gage & $\begin{array}{c}\text { Delta- } \\
\text { shape }\end{array}$ & $\underline{0.3083}$ & 0 & 12,685 & 15,466 & 166.64 & OK \\
\hline 20 Gage & $\begin{array}{c}\text { Delta- } \\
\text { shape }\end{array}$ & $\underline{0.4402}$ & 0 & 17,328 & 21,619 & 166.67 & NG \\
\hline 16 Gage & $\begin{array}{c}\text { Original } \\
\text { column }\end{array}$ & $\underline{1.497}$ & 0 & $\underline{31,999}$ & $\underline{52,937}$ & $\underline{284.4}$ & NG \\
\hline
\end{tabular}

Note:

1. Limitations:

a. The limitation of steel stress $\phi F_{\text {steel }}=0.85 \times 33=28.05 \mathrm{ksi}$.

b. The limitation of panel deformation is $\mathrm{L} / 360=0.30$ inch.

c. The limitation of slenderness ratio is 200 .

2. The underlined values are unacceptable compared with the above limitations.

\subsubsection{Conclusion from analysis of system columns}

Based on the analytical results, following conclusions were drawn:

1. Twist or torsional deformation could be clearly observed in the C-shape columns under loading due to the asymmetry about the weak axis in the cross-section. The delta-shape and original columns exhibited flexural buckling deformation only. The maximum deformations of 
delta-shape and original columns occurred at about 45" - 46" from the top surfaces of the columns.

2. The maximum compression of all the columns occurred at the bottom of the columns under load Case 1 and Case 2. Under load Case 1, the maximum tensile of the original column occurred at the bottom of the columns, and no tensile occurred at the C-shape and Delta-shape columns. The maximum tensile stresses of all the columns occurred at the bottom of the columns under load Case 2.

3. The stresses, deformations and slenderness ratios in C-channel columns and Delta columns were acceptable when columns were subjected to wind load based on column area only (load Case 1). The slenderness ratio of original columns was unacceptable.

4. Only Delta columns made of 16 and 18 gage steel met all of the design criteria when the columns subjected to wind load based on 36 in wide tributary area (24 in. for C-shape column). For columns with the same Gage and under the same loads, Delta column had the smallest stress and original column had the largest stress.

Considering the deformation, slenderness ratio and stresses of the columns, Delta-columns made of 16 and 18 gage steel were the best choice among the columns studied in this project.

\subsection{Conclusions on the window header}

For the stresses in the longitudinal direction of the window header, the maximum tensile and compressive stresses occurred at the bottom of the front steel facing. The maximum compressive stress in the PU foam were almost zero, indicating the steel facings carried almost all of the loads on the window header. Even under the larger vertical live load, the maximum stress in steel facing was 28,000 psi while the maximum stress in foam was only 5.797 psi. 



\section{CHAPTER 9}

\section{PLANS FOR FUTURE COLLABORATION}

The main purpose of this project was development and analysis of a new building envelope technology that maximizes internal integration by utilizing a highly-efficient building envelope with high-R thermal insulation, active thermal mass and superior air-tightness. The project team

approach was to combine four common building technologies in a novel way. Structural Insulated Panel (SIP) technology was utilized as a structural vehicle and for high-R thermal insulation. Novel approach to panel-to-panel connections provided excellent air and moisture tightness, but it also works in a similar way as conventional wall framing.

It is expected that follow-up energy performance analysis for heating and cooling dominated climates and enhanced with full scale field testing in several U.S. locations can be considered as future collaboration targets. 
ORNL/NFE-04-00699

INTERNAL DISTRIBUTION

1. A. Desjarlais

2. B. DeVault

3. J. Green

4. P. Hughes

5. J. Kosny

6. Laboratory Records-RC

7. Laboratory records for submission to OSTI

\section{EXTERNAL DISBRIBUTION}

1. Sally Gaskin, sally@sgiventures.net

2.X. Sharon Huo, xhuo@tntech.edu

3. Marilyn Brown, Marilyn.brown@pubpolicy.gatech.edu 